JULIO FERNANDES GONÇALVES

ESTUDO NUMÉRICO DO COMPORTAMENTO DE MUROS DE SOLO REFORÇADO COM GEOSSINTÉTICO

São Paulo

2016 
JULIO FERNANDES GONÇALVES

\title{
ESTUDO NUMÉRICO DO COMPORTAMENTO DE MUROS DE SOLO REFORÇADO COM GEOSSINTÉTICO
}

\author{
Dissertação apresentada à Escola \\ Politécnica da Universidade de São \\ Paulo, Programa de Pós-Graduação \\ em Engenharia Civil, para a obtenção
} do título de Mestre em Ciências

Área de Concentração: Engenharia Geotécnica

Orientadora: Profa. Dra. Maria Eugenia Gimenez Boscov

São Paulo

2016 
Este exemplar foi revisado e corrigido em relação à versão original, sob responsabilidade única do autor e com a anuência de seu orientador.

São Paulo, de de

Assinatura do autor:

Assinatura do orientador:

Catalogação-na-publicação

\section{Gonçalves, Julio Fernandes}

Estudo numérico do comportamento de muros de solo reforçado com geossintético / J. F. Gonçalves -- versão corr. -- São Paulo, 2016.

$158 \mathrm{p.}$

Dissertação (Mestrado) - Escola Politécnica da Universidade de São Paulo. Departamento de Engenharia de Construção Civil.

1.Solo Reforçado 2.Geotecnia 3.Geossintéticos 4.Solo tropical 5.Método dos Elementos Finitos I.Universidade de São Paulo. Escola Politécnica. Departamento de Engenharia de Construção Civil II.t. 
Dedico esta dissertação à minha esposa Juliana Alencar, minha inspiração e o motivo que me faz lutar. 


\section{AGRADECIMENTOS}

Aos meus pais, pelo ensino da importância do estudo e por todo investimento pessoal e financeiro para que um dia eu pudesse me desenvolver profissionalmente.

À professora Maria Eugênia, excepcional como professora e ser humano, que se dedicou intensamente para a conclusão deste trabalho. Agradeço especialmente pelas longas tardes de trabalho e por sua paciência.

Ao professor Fernando Portelinha, por realizar comigo um ótimo trabalho de coorientador, imprescindível para o caminhamento da minha pesquisa.

À todos os professores do programa de pós-graduação da EPUSP, cujas críticas, lições profissionais e ensinamentos transmitidos foram importantes para a ampliação do meu conhecimento.

Aos funcionários do laboratório de mecânica dos solos e às secretárias da pós-graduação da EPUSP, pelo exemplo de dedicação e cordialidade.

Aos amigos da pós-graduação, pelo consolo nos momentos difíceis, pelo companheirismo, pelos estudos em grupo primordiais para aprovação nas disciplinas, pelas discussões técnicas e pelo carinho recebido.

A Capes pela bolsa de apoio a pesquisa. 


\section{RESUMO}

O uso de reforços geossintéticos tem se apresentado como uma solução eficiente que permite reduzir os custos de implantação de estruturas de contenção. Seu comportamento pode ser estudado com a utilização de softwares de elementos finitos na intenção de obter configurações ainda mais econômicas. Neste trabalho foram simulados muros de solo reforçados com geossintéticos (MSRG) pelo método dos elementos finitos (software Plaxis 8.2), analisando-se como parâmetro o deslocamento máximo da face dos muros e a máxima força mobilizada no reforço. Inicialmente, desenvolveu-se e calibrou-se um modelo numérico a partir de um modelo físico construído e monitorado encontrado na literatura. Em seguida construiu-se um modelo numérico de MSRG hipotético e realizaram-se estudos paramétricos com as variáveis: tipo de solo, priorizando-se solos finos tropicais; rigidez e espaçamento do reforço; e inclinação e altura do muro. Os resultados corroboraram a bem sucedida prática nacional de construção de muros reforçados com solos finos tropicais, sendo que a coesão se mostrou um parâmetro importante no comportamento de MSRG construídos com solos finos.

PALAVRAS-CHAVE: Solo reforçado. Geotecnia. Geossintéticos. Solo tropical. Método dos elementos finitos. 


\begin{abstract}
The use of geosynthetic reinforcements is an efficient solution that reduces the costs of implantation of containment structures. Their behavior can be studied by the use of finite element software, with the goal to obtain more economical configurations. In this study, geosynthetic reinforced retaining walls (MSRG) were simulated by the finite element method (software Plaxis 8.2), analyzing as a parameter the maximum face displacement and the maximum force mobilized in the reinforcement. Initially, a numeric model was developed and calibrated from a constructed and monitored physical model of the literature. After, a numerical model of hypothetical MSRG was constructed and parametric studies were done with the following variables: soil type, prioritizing tropical fine soils; reinforcement stiffness and spacing, and slope and height of the wall. The results corroborated the successful brazilian practice at the building reinforced MSRG with tropical fine soils, due cohesion being an important parameter in the behavior of MSRGs constructed with fine soils.
\end{abstract}

KEYWORDS: Reinforced soil. Geotechnics. Geosynthetic. Tropical soil. Finite element method. 


\section{LISTA DE FIGURAS}

Figura 2.1 - MSRG utilizando geotêxtil e solo fino tropical ............................... 18

Figura 2.2 - Ábacos para determinação do máximo esforço de tração no reforço 21

Figura 2.3 - Curva de compatibilidade solo-reforço ............................................ 24

Figura 2.4 - Resistência ao arrancamento de geogrelha em função da tensão confinante para três solos............................................................................ 26

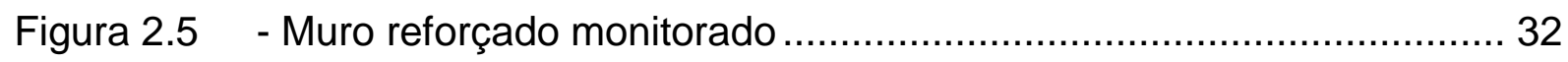

Figura 2.6 - Equipamentos de leitura de tensão utilizados no monitoramento ..... 33

Figura 2.7 - Modelo físico monitorado ........................................................ 34

Figura 2.8 - Deslocamentos horizontais medidos pelos inclinômetros no final de

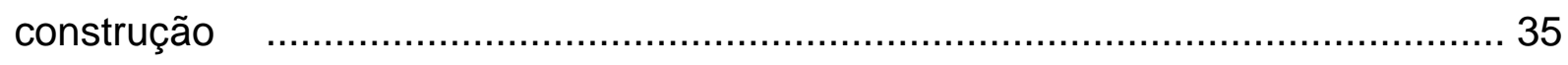

Figura 2.9 - Localização da máxima tensão nos reforços no final de construção 35

Figura 2.10 - Foto do muro reforçado com geotêxtil tecido e não tecido ................ 36

Figura 2.11 - Potencial superficie de rutura do MSRG com geotêxtil não tecido.... 37

Figura 2.12 - Representação do protótipo comparado a um muro reforçado ......... 39

Figura 2.13 - Sistema de aplicação de tensões verticais........................................ 40

Figura 2.14 - Curvas: Carga x Alongamento ................................................... 41

Figura 2.15 - Localização da instrumentação no protótipo …………………….... 42

Figura 2.16 - Distribuição de tensões no modelo físico ......................................... 43

Figura 2.17 - Deslocamentos da face do modelo físico ........................................ 44

Figura 2.18 - Diferentes técnicas de amarração do reforço ...................................... 48

Figura 2.19 - Hardening Soil Model (HSM) ………....................................... 54

Figura 2.20 - Metodologia da simulação da compactação …………………….... 56

Figura 2.21 - Malha do modelo numérico do muro de solo reforçado .................... 59

Figura 2.22 - Fator de segurança e superfície de ruptura sem os drenos funcionando 61

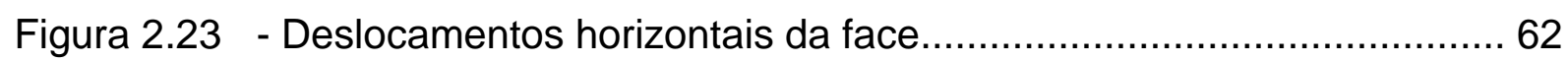

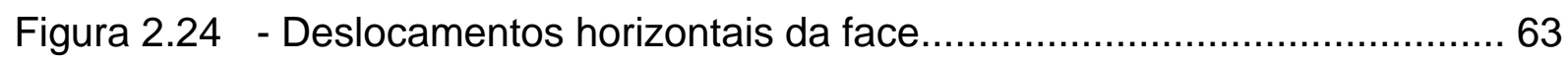

Figura 3.1 - Seção transversal do modelo físico de MSRG de Portelinha (2012) 67

Figura 3.2 - Condições do entorno do modelo físico. ......................................... 68

Figura 3.3 - Modelo construído no software Plaxis............................................ 70

Figura 3.4 - Malha de elementos finitos do modelo numérico ............................ 71 
Figura 3.5 - Comparação entre os deslocamentos horizontais medidos no modelo físico de Portelinha (2012) e calculados no modelo numérico................................ 73 Figura 3.6 - Construção do protótipo em etapas no software Plaxis ................... 75 Figura 3.7 - Comparação entre os deslocamentos horizontais calculados no modelo numérico sem e com simulação da compactação ...................................... 76 Figura 3.8 - Comparação entre os deslocamentos horizontais medidos no modelo físico de Portelinha (2012) e calculados no modelo numérico com simulação de compactação e deslocamento de $0,005 \mathrm{~m}$ na primeira camada 77 Figura 3.9 - Deformação horizontal no geossintético no trecho mais solicitado em função da distância até a face externa 78 Figura 3.10 - Comparação entre a potencial superfície de ruptura obtida no modelo físico de Portelinha (2012) e potencial superfície obtida no modelo numérico ......... 78 Figura 3.11 - Influência da rigidez do solo no deslocamento máximo da face ....... 80 Figura 3.12 - Influência da rigidez do reforço no deslocamento máximo da face ... 81 Figura 3.13 - Influência da rigidez do reforço na deformação máxima no reforço.. 82 Figura 3.14 - Influência da rigidez do reforço no esforço mobilizado $(\mathrm{kN})$.... 83 Figura 3.15 - Influência da variação paramétrica na potencial superfície de ruptura. 83

Figura 4.1 - Modelo numérico do MSRG 88

Figura 5.1 - Deformada de um MSRG de $15 \mathrm{~m}$ de altura construído com solo MH e reforço de rigidez de $100 \mathrm{kN} / \mathrm{m}$. 95

Figura 5.2 - Exemplo de distribuição da força mobilizada no reforço 96 Figura 5.3 - Deslocamento horizontal máximo na face do MSRG construído com solos tropicais e reforço de $11 \mathrm{kN} / \mathrm{m}$

Figura 5.4 - Força máxima mobilizada no reforço do MSRG construído com solos tropicais e reforço de $11 \mathrm{kN} / \mathrm{m}$

Figura 5.5 - Deslocamento horizontal máximo na face do MSRG construído com solos tropicais e reforço de $100 \mathrm{kN} / \mathrm{m}$ 98 Figura 5.6 - Força máxima mobilizada no reforço do MSRG construído com solos tropicais e reforço de $100 \mathrm{kN} / \mathrm{m}$. 99

Figura 5.7 - Deslocamento horizontal máximo na face do MSRG construído com solos tropicais e reforço de $500 \mathrm{kN} / \mathrm{m}$ 100 
Figura 5.8 - Força máxima mobilizada no reforço do MSRG construído com solos tropicais e reforço de $500 \mathrm{kN} / \mathrm{m}$

Figura 5.9 - Influência do tipo de solo na potencial superfície de ruptura do MSRG

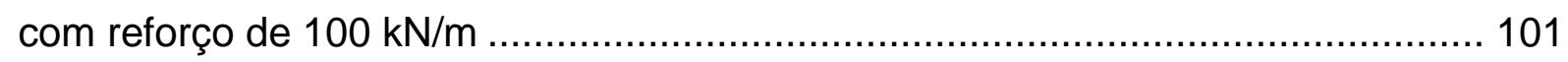

Figura 5.10 - Influência da coesão no deslocamento horizontal em MSRG ......... 103

Figura 5.11 - Influência da coesão na mobilização do reforço em MSRG ............. 103

Figura 5.12 - Influência da rigidez do solo no deslocamento horizontal em MSRG....

Figura 5.13 - Influência da rigidez do solo na mobilização do reforço em MSRG 105 Figura 5.14 - Influência do comprimento do reforço no deslocamento horizontal em MSRG 106

Figura 5.15 - Influência do comprimento do reforço na mobilização do reforço em MSRG 106

Figura 5.16 - Influência da rigidez do reforço no deslocamento horizontal em MSRG 107

Figura 5.17 - Influência da rigidez do reforço na mobilização do reforço em MSRG..

Figura 5.18 - Influência do ângulo de atrito no deslocamento horizontal - coesão 10 $\mathrm{kPa}$ 109

Figura 5.19 - Influência do ângulo de atrito na mobilização do reforço - coesão 10 $\mathrm{kPa}$

Figura 5.20 - Influência do ângulo de atrito no deslocamento horizontal - coesão 20 $\mathrm{kPa}$

Figura 5.21 - Influência do ângulo de atrito na mobilização do reforço - coesão 20 $\mathrm{kPa}$

Figura 5.22 - Influência do ângulo de atrito no deslocamento horizontal - coesão 40 $\mathrm{kPa}$ 112

Figura 5.23 - Influência do ângulo de atrito na mobilização do reforço - coesão 40 $\mathrm{kPa}$

Figura 5.24 - Influência do ângulo de atrito no deslocamento horizontal - coesão 60 $\mathrm{kPa}$

Figura 5.25 - Influência do ângulo de atrito na mobilização do reforço - coesão 60 $\mathrm{kPa}$ 
Figura 5.26 - Influência da coesão no deslocamento horizontal - E=10 MPa...... 115

Figura 5.27 - Influência da coesão na mobilização do reforço - E=10 MPa ......... 115

Figura 5.28 - Influência da coesão no deslocamento horizontal - E=20 MPa ...... 116

Figura 5.29 - Influência da coesão na mobilização do reforço - E=20 MPa......... 116

Figura 5.30 - Influência da coesão no deslocamento horizontal - E=40 MPa ...... 117

Figura 5.31 - Influência da coesão na mobilização do reforço - E=40 MPa......... 117

Figura 5.32 - Influência da coesão no deslocamento horizontal - E=60 MPa...... 118

Figura 5.33 - Influência da coesão na mobilização do reforço - E=60 MPa ......... 118

Figura 5.34 - Influência do módulo de elasticidade no deslocamento horizontal máximo- coesão $10 \mathrm{kPa}$

Figura 5.35 - Influência do módulo de elasticidade na força máxima mobilizada no reforço- coesão $10 \mathrm{kPa}$ 120

Figura 5.36 - Influência do módulo de elasticidade no deslocamento horizontal máximo- coesão $20 \mathrm{kPa}$

Figura 5.37 - Influência do módulo de elasticidade na força máxima mobilizada no reforço - coesão $20 \mathrm{kPa}$

Figura 5.38 - Influência do módulo de elasticidade no deslocamento horizontal coesão $40 \mathrm{kPa}$.

Figura 5.39 - Influência do módulo de elasticidade na força máxima mobilizada no reforço - coesão $40 \mathrm{kPa}$ 122

Figura 5.40 - Influência do módulo de elasticidade no deslocamento horizontal máximo- coesão 60 kPa

Figura 5.41 - Influência do módulo de elasticidade na força máxima mobilizada no reforço - coesão $60 \mathrm{kPa}$ 123

Figura 5.42 - Solo plastificado na simulação PAR 18 124

Figura 5.43 - Influência da variação paramétrica do solo na potencial superfície de ruptura de MSRG com reforço de rigidez de $1000 \mathrm{kN} / \mathrm{m}$ 125 Figura 5.44 - Influência da inclinação da face no deslocamento horizontal máximo coesão $20 \mathrm{kPa}$ e E=10 MPa

Figura 5.45 - Influência da inclinação da face na força máxima mobilizada no reforço - coesão $20 \mathrm{kPa}$ e E=10 $\mathrm{MPa}$.

Figura 5.46 - Influência da inclinação da face no deslocamento horizontal máximo coesão $20 \mathrm{kPa}$ e E=60 MPa 128 
Figura 5.47 - Influência da inclinação da face na força máxima mobilizada no reforço - coesão $20 \mathrm{kPa}$ e E=60 MPa

Figura 5.48 - Influência da inclinação da face no deslocamento horizontal máximo ângulo de atrito $\left(\varphi=20^{\circ}\right)$ e $E=10 \mathrm{MPa}$ 129

Figura 5.49 - Influência da inclinação da face na força máxima mobilizada no reforço - ângulo de atrito $\left(\varphi=20^{\circ}\right)$ e $E=10 \mathrm{MPa}$ 130

Figura 5.50 - Influência do espaçamento do reforço no deslocamento horizontal máximo 131

Figura 5.51 - Influência do espaçamento do reforço na força mobilizada no reforço . 


\section{LISTA DE TABELAS}

Tabela 2.1 - Especificações de solos para MSRGs em diferentes países ............ 28

Tabela 2.2 - Comportamento de muros reforçados utilizando materiais ............... 29

Tabela 2.3 - Cargas de tração em camadas de reforço ....................................... 47

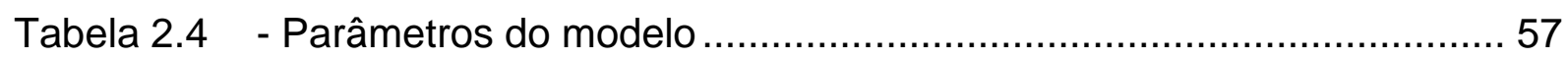

Tabela 3.1 - Parâmetros dos solos tropicais utilizados nas simulações ................ 79

Tabela 4.1 - Variação paramétrica do modelo físico com três solos tropicais e

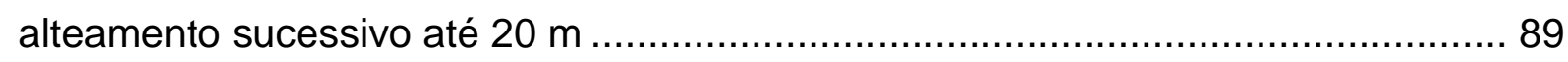

Tabela 4.2 -Variação dos parâmetros nas simulações......................................... 90

Tabela 4.3 - Variação paramétrica com alteamento sucessivo ……...................... 91

Tabela 4.4 - Variação paramétrica sem alteamento progressivo com foco no solo ..

Tabela 4.5 - Variação paramétrica sem alteamento progressivo com foco na

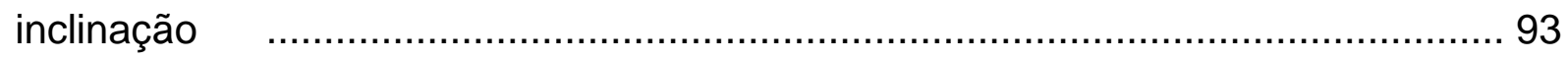

Tabela 4.6 - Variação paramétrica sem alteamento progressivo com foco no

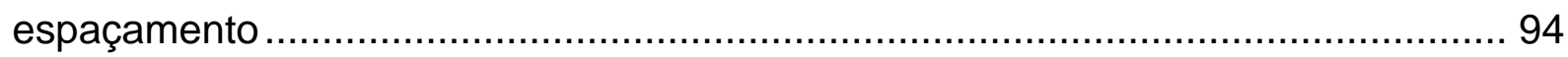




\section{ÍNDICE}

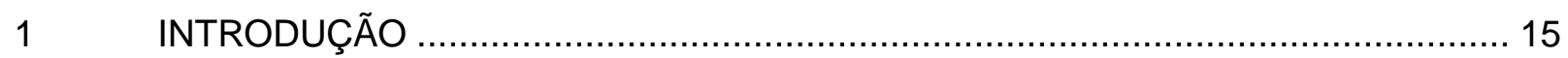

1.1 OBJETIVO

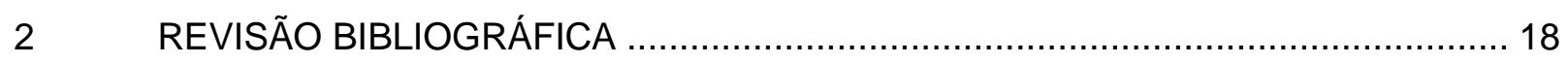

2.1 MURO DE SOLO REFORÇADO COM GEOSSINTÉTICO ……........................... 18

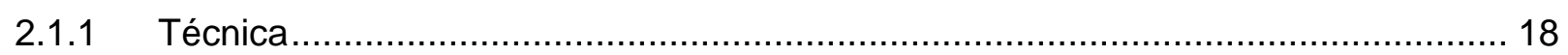

2.1.2 Geossintéticos utilizados como reforços .......................................................... 22

2.1.3 Interação entre solo e geossintético ………………...................................... 24

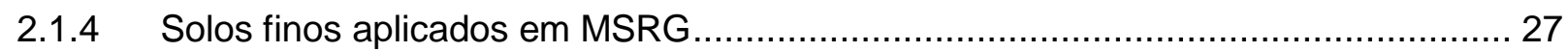

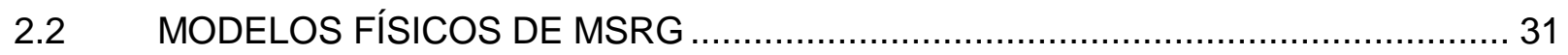

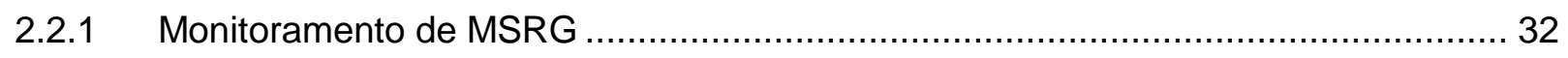

2.2.2 Protótipos de muros reforçados com geossintéticos .............................................. 38

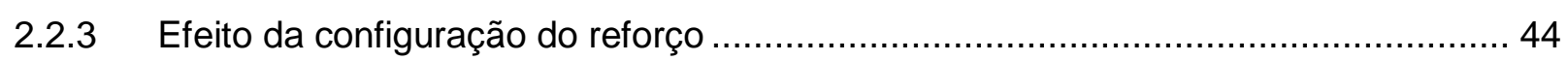

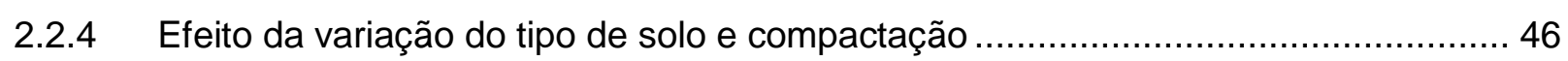

2.2.5 Efeito da variação da rigidez e inclinação da face ............................................... 47

2.2.6 Efeito da altura do muro.............................................................................. 49

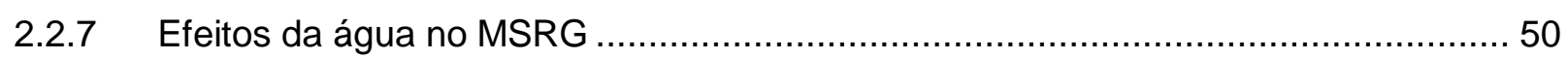

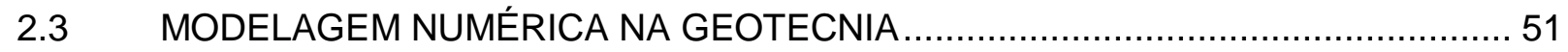

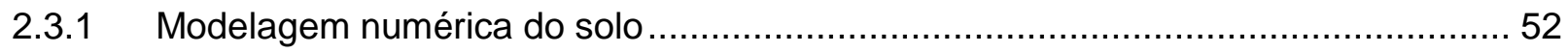

2.3.1.1 Efeito da compactação na modelagem numérica ................................................ 55

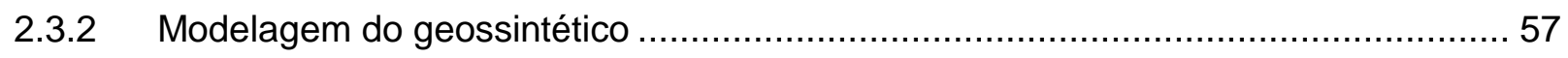

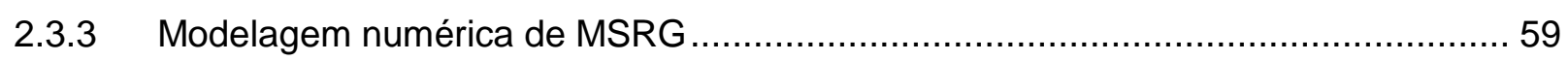

3 MODELAGEM NUMÉRICA BASEADA EM MODELO FÍSICO................................6 65

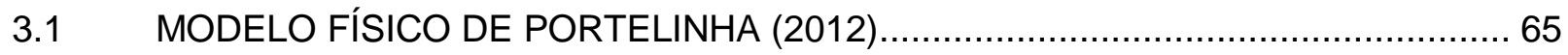

3.2 MODELO NUMÉRICO BASEADO NO MODELO FÍSICO DE PORTELINHA (2012)69

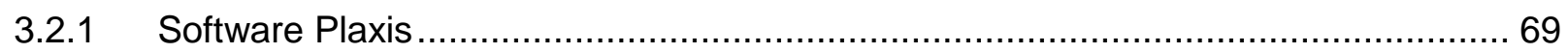

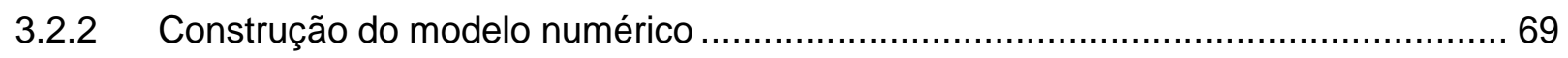

3.2.3 Parâmetros de entrada do modelo constitutivo ………………............................ 71

3.3 CALIBRAÇÃO DO MODELO NUMÉRICO ……………....................................... 72

3.4 ESTUDO PARAMÉTRICO NO MODELO NUMÉRICO ........................................... 79

4 MODELAGEM NUMÉRICA DE UM MSRG HIPOTÉTICO ….................................... 85

4.1 CONSTRUÇÃO DO MODELO NUMÉRICO DE MSRG ...................................... 85

4.2 SIMULAÇÕES DO MODELO NUMÉRICO DE MSRG COM ALTEAMENTOS SUCESSIVOS COM TRÊS SOLOS TROPICAIS ………….......................................... 88

4.3 SIMULAÇÕES DO MODELO NUMÉRICO DE MSRG COM ALTEAMENTOS

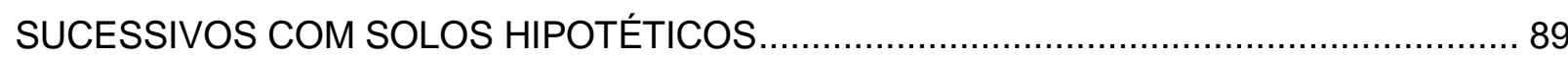


4.4 SIMULAÇÕES DE MSRG DE 10 M DE ALTURA COM VARIAÇÃO PARAMÉTRICA91

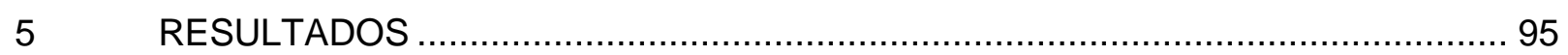

5.1 SIMULAÇÕES DO MODELO NUMÉRICO DE MSRG COM ALTEAMENTOS SUCESSIVOS COM TRÊS SOLOS TROPICAIS. 95

5.2 SIMULAÇÕES DE MSRG COM ALTEAMENTO SUCESSIVO COM SOLOS HIPOTÉTICOS 102

5.3 SIMULAÇÕES DE MSRG DE 10 M DE ALTURA COM VARIAÇÕES

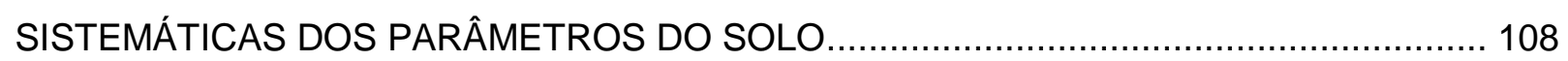

5.3.1 Estudo da influência do ângulo de atrito do solo................................................ 109

5.3.2 Estudo da influência da coesão do solo ..................................................... 115

5.3.3 Estudo da influência do módulo de elasticidade do solo ..................................... 119

5.4 SIMULAÇÕES DE MSRG DE 10 M DE ALTURA COM VARIAÇÕES DA INCLINAÇÃO DO MURO ............................................................................... 126

5.5 SIMULAÇÕES DE MSRG DE 10 M DE ALTURA COM ENVELOPAMENTO COM VARIAÇÕES DE ESPAÇAMENTO E RIGIDEZ DO REFORÇO .................................... 130

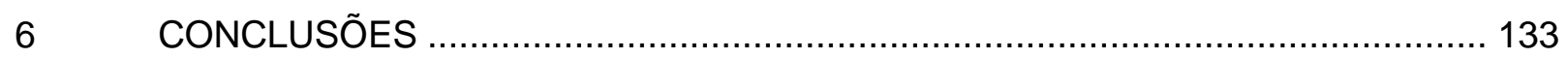

6.1 MODELAGEM NUMÉRICA DO MODELO FÍSICO ESTUDADO .......................... 133

6.2 MODELAGEM NUMÉRICA DE MUROS DE SOLOS REFORÇADOS COM GEOSSINTÉTICO (MSRG) COM ALTEAMENTO PROGRESSIVO ................................ 133

6.3 MODELAGEM NUMÉRICA DE MSRG COM ALTURA FIXA DE 10 METROS ...... 134

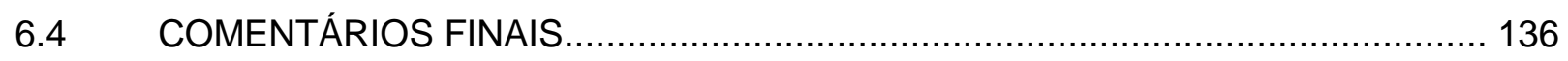

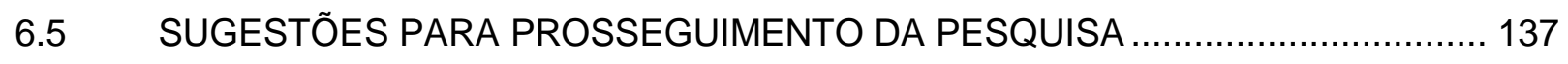

$7 \quad$ REFERÊNCIAS BIBLIOGRÁFICAS ...................................................... 138

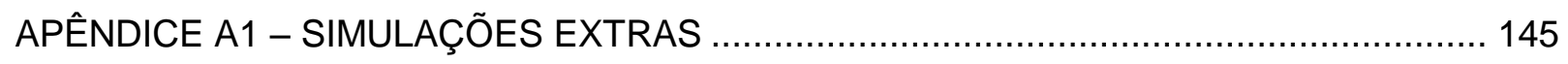

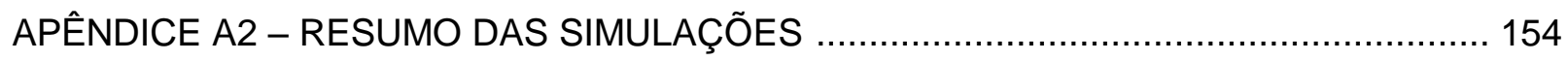




\section{INTRODUÇÃO}

A técnica do reforço de solo é utilizada na engenharia há muitos séculos, quando se associavam materiais fibrosos como palha e bambu ao solo. O princípio de funcionamento dessa técnica é a adição de materiais ao solo que tenham resistência à tração, para suprir a baixa resistência à tração do solo.

Um grande avanço na avaliação e dimensionamento do uso de reforços no solo se deu a partir da difusão da técnica de Terra Armada, na década de 60, pelo engenheiro Henri Vidal, que utilizava como reforço fitas metálicas. Na década de 70 iniciou-se então a aplicação de geossintéticos na estabilização de aterros, ampliando as possibilidades de construção de muros de solos reforçados.

O uso de geossintéticos é uma boa maneira de reduzir os custos de implantação de uma estrutura de arrimo, viabilizando obras de contenção maiores, devido às elevadas resistências à tração, durabilidade e variedade desses materiais. Porém, a análise de estabilidade de muros de solos reforçados com geossintéticos (MSRG) apresenta certa complexidade.

Estudos sobre o comportamento de MSRG verificaram que para realizar uma análise de estabilidade realista é necessário considerar vários fatores: o tipo de geossintético, o tipo de solo, a altura do muro, a inclinação da face, a rigidez da face, o tipo de ancoragem, o grau de compactação do solo e o arranjo das inclusões (EHRLICH; MITCHELL, 1994; HELWANY; REARDON; WU, 1999; PEDROSO et al., 2006; PALMEIRA, 2009).

Em geral, as normas internacionais como AASHTO (2002), FHWA (1998) e BS8006 (19 95) recomendam a utilização de solos granulares na construção de solos reforçados, por possuírem maior permeabilidade e resistência ao cisalhamento. Solos finos (não granulares) em MSRG, no entanto, vêm sendo utilizados com sucesso no Brasil desde 1984; porém, é necessário que o projeto seja dimensionado de acordo com as características desses solos.

A análise de estabilidade externa pode ser feita como as estruturas convencionais de arrimo, por meio de equilíbrio limite. Por outro lado, na análise da 
estabilidade interna a utilização dos métodos de equilíbrio limite muitas vezes leva a erros grosseiros de dimensionamento, inclusive contra a segurança (EHRLICH; BECKER, 2009). A análise de estabilidade interna deve-se basear preferencialmente na compatibilidade de deformações entre solo e reforço, por meio de métodos baseados em condições de trabalho, como o de Dantas e Ehrlich (2000), ou de técnicas computacionais avançadas, como softwares de elementos finitos. O projeto depende, portanto, da razão entre a rigidez do solo e a rigidez do reforço.

De fato, para reforços com elevado valor de rigidez, a mobilização se procede com baixos níveis de deformação do solo. Já em reforços mais flexíveis, tais como os geotêxteis não tecidos, significantes deformações podem ser requeridas até que a força de mobilização no reforço seja desenvolvida. Consequentemente, quando materiais extensíveis são usados, a magnitude da deformação e as forças de mobilização aceitáveis passam a compor critérios de projeto em substituição à tensão de ruptura, uma vez que promoverão deslocamentos consideráveis na estrutura (EHRLICH; MITCHELL, 1994). Conhecendo o efeito da compatibilidade de deformações entre solo e reforço, economia significativa pode ser alcançada em projetos, uma vez que reforços rígidos, mais caros, nem sempre são obrigatórios para o bom desempenho da estrutura, conforme observado por Oliveira (2006).

A análise de compatibilidade de deformações pode ser facilitada com o uso de modelos numéricos em que é possível variar os valores de rigidez dos materiais envolvidos e que analisem a relação entre a tensão e a deformação. A velocidade das simulações numéricas possibilita simular diversas combinações e geometrias em um menor tempo e custo. Com a realização de uma grande diversidade de cenários de MSRG é possível compreender como as combinações impactam a estabilidade e consequentemente dar subsídios para uma escolha mais econômica. 


\subsection{OBJETIVO}

Esta pesquisa tem como objetivo geral avaliar a influência da geometria e das combinações de materiais - solo e geossintético - em um muro de solo reforçado com geossintético (MSRG) por meio de modelagem numérica, utilizandose como parâmetros de avaliação o deslocamento máximo na face e a força máxima mobilizada no reforço.

Os objetivos específicos da pesquisa são:

- Familiarização com o software de elementos finitos Plaxis 8.2 para modelagem numérica de MSRG por meio da calibração de um modelo físico de MSRG da literatura, comparando-se deformações, força máxima mobilizada nos reforços e deslocamentos medidos e calculados.

- Realização de simulações numéricas de um MSRG hipotético variando-se o tipo de solo (priorizando os finos tropicais); a rigidez e o espaçamento do reforço; a inclinação da face e a altura do muro. 


\section{REVISÃO BIBLIOGRÁFICA}

\subsection{MURO DE SOLO REFORÇADO COM GEOSSINTÉTICO}

\subsubsection{Técnica}

Muros de solos reforçados com geossintético (MSRG) são utilizados no Brasil há algumas décadas. Em 1984 foi construído o primeiro MSRG no país, com geotêxtil e solo fino, utilizando-se a técnica de autoenvelopamento, conforme mostrado na Figura 2.1. Parte da estrutura foi construída com geotêxtil tecido e parte, com geotêxtil não tecido.

Figura 2.1 - MSRG utilizando geotêxtil e solo fino tropical

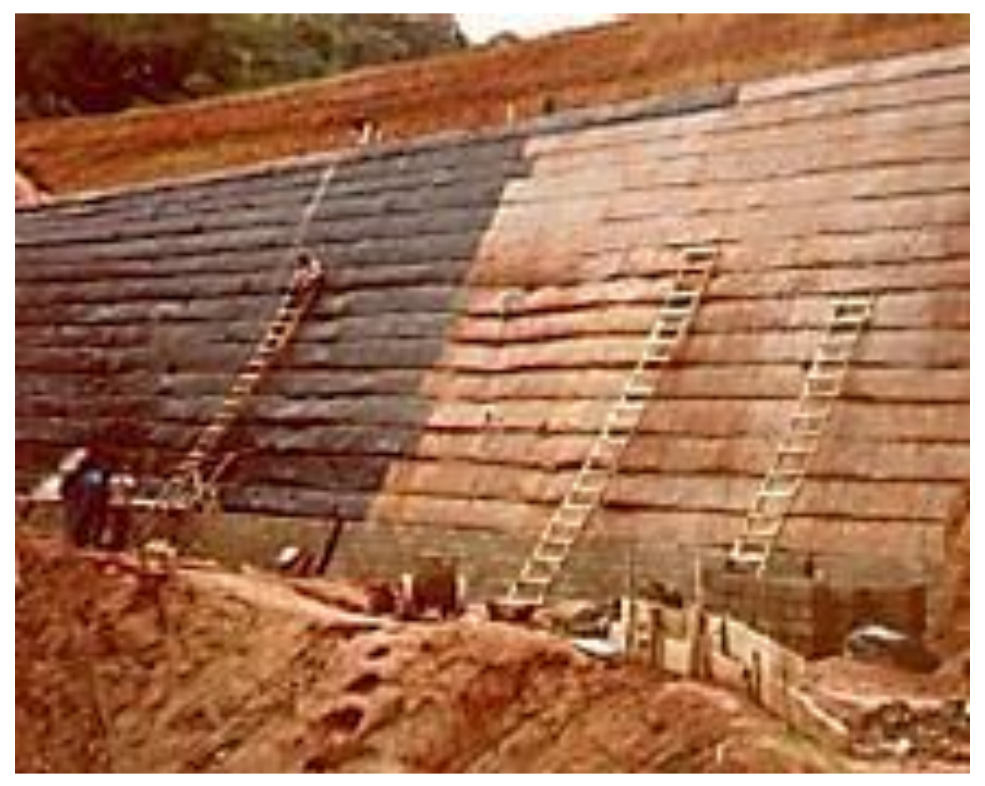

Fonte: Carvalho et al. (1986)

O muro, localizado próximo à rodovia que liga Taubaté a Campos de Jordão (CARVALHO et al., 1986), tem $10 \mathrm{~m}$ de altura e inclinação da face de 1H:2V. Esse muro foi um marco na engenharia por consolidar a viabilidade técnica e econômica de MSRG de grande altura utilizando solos tropicais brasileiros.

Solos reforçados funcionam da seguinte forma: como o solo tem baixa resistência à tração, é adicionado um reforço que trabalha junto com o solo; consequentemente a massa de solo e reforços tende a agir como um corpo monolítico coeso, suportando o seu próprio peso bem como as cargas externas para as quais tenha sido projetado. Os reforços são materiais metálicos ou poliméricos 
com elevada resistência à tração, colocados em camadas horizontais. Assim aumenta-se a resistência à tração do maciço devido ao atrito na interface com os elementos longitudinais e, no caso de geogrelhas, também pelo embricamento do solo preso nos vazios e pela resistência passiva contra os elementos transversais (EHRLICH; BECKER, 2009).

O comportamento de um MSRG é condicionado ao método construtivo adotado. Os dois métodos mais difundidos são o do sistema autoenvelopado e o do sistema com blocos segmentais (EHRLICH; AZAMBUJA, 2003). Detalhes dos processos construtivos de MSRG podem ser obtidos em Vertematti (2015).

A construção de um muro reforçado com sistema autoenvelopado consiste em estender o geossintético, compactar a camada de solo com espessura de acordo com o projeto e dobrar o geossintético sobre a camada de solo compactado, confinando a superfície externa de solo entre duas camadas de reforço. As camadas vão sendo assim construídas até atingir a altura de projeto. No final da construção, é feito o faceamento definitivo.

O muro pode ser construído com ancoragens superiores ou inferiores. Quando a ponta da manta fica na camada superior é classificada como ancoragem superior, do contrário é classificada como ancoragem inferior. Geralmente o muro autoenvelopado é construído com o auxílio de formas removíveis. Outro método construtivo é o de formas perdidas; neste caso, a forma utilizada antes da compactação fica integrada na estrutura definitiva.

No sistema de blocos segmentais a construção se dá pela instalação do revestimento externo ancorado ao geossintético, utilizando blocos que possuem dispositivos de encaixe, facilitando assim o alinhamento do muro e proporcionando sua ancoragem. Os blocos servem de formas laterais para a compactação das camadas de solo, como faceamento definitivo e como ancoragem para os reforços.

Independentemente do método, o sistema construtivo tem que possibilitar que o solo seja compactado; que o reforço possa se fixar nas estruturas externas (ou que ele seja ancorado no próprio solo), e que os sistemas de drenagem e de proteção superficial sejam instalados. 
A verificação da estabilidade de um MSRG é separada em duas condições: interna e externa. A estabilidade externa tem o mesmo conceito de um muro de arrimo tradicional, sendo necessário verificar a estabilidade para o deslizamento, tombamento, capacidade de carga da fundação e estabilidade global. A partir da verificação da estabilidade externa é estabelecido o comprimento do reforço.

A estabilidade interna é função do ganho de resistência do solo reforçado com o uso do reforço. Basicamente, é a condição mais crítica para que não ocorram rupturas por tração, arrancamento dos esforços ou instabilidade localizada da face (EHRLICH; BECKER, 2009). O espaçamento vertical e resistência do reforço são determinados em função da estabilidade interna.

A resistência ao arrancamento e a rigidez dos reforços são dados obtidos por meios de ensaios laboratoriais. Consecutivamente é verificado se a tensão solicitante no campo está adequada às características do reforço e à sua interação com o solo.

Ehrlich e Mitchell (1994) propõem um método para estimar a tensão a que o reforço é submetido no interior do MSRG. Esse método admite que o solo e o geossintético tenham perfeita aderência, ou seja, não existe o deslocamento relativo entre eles, e disponibiliza ábacos para encontrar a tensão em cada reforço. $\mathrm{Na}$ Figura 2.2 é observado um exemplo desses ábacos para ângulo de atrito de $35^{\circ}$. 
Figura 2.2 - Ábacos para determinação do máximo esforço de tração no reforço

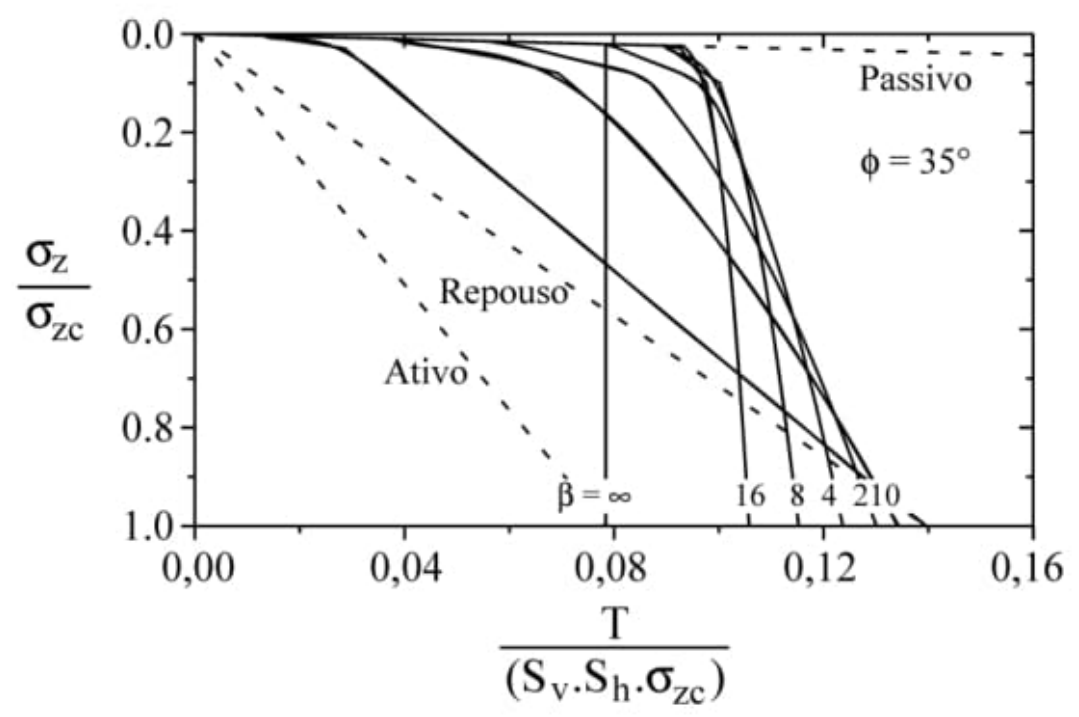

Fonte: Ehrlich e Mitchell (1994)

Observa-se que o método equaciona essa tensão máxima a partir do ângulo de atrito do solo, espaçamento e comprimento do reforço, tensão devido ao peso próprio e à compactação, onde:

- $\phi$ é o ângulo de atrito;

- $\sigma_{z}$ é a tensão vertical;

- $\sigma_{z c}$ é a tensão vertical máxima incluindo a compactação;

- $\beta$ é a deformabilidade relativa solo-reforço;

- T é tração máxima no reforço;

- Sv é o espaçamento vertical entre reforços e

- Sh é o comprimento do reforço.

Durante o procedimento do cálculo, a rigidez do geossintético também é levada em consideração. $O$ valor da tensão de tração, representado pela letra $T$ no ábaco está adimensionalizado em relação aos parâmetros $S_{v}, S_{h}$ e $\sigma_{z c}$. Com a determinação da tensão, é possível prever a deformação específica do reforço pela sua rigidez. O inverso também é válido, pois a partir das deformações internas, é possivel prever qual é a tração no reforço.

Para solos coesivos, o método de Ehrlich e Mitchell (1994) foi generalizado através dos ábacos de Dantas e Ehrlich (2000), que incluem a coesão do solo. 
Um método alternativo para previsão de tensão e deformações é o estudo que Helwany; Reardon e Wu (1999), que realizaram a simulação numérica de 144 combinações, com três reforços geossintéticos diferentes, dezesseis tipos de solos e três dimensões de caixa teste. Diferentemente de Dantas e Erlich (2000), que se basearam em modelos físicos e análiticos, Helwany; Reardon e Wu (1999) utilizaram também modelos numéricos, com os quais foi possível realizar uma grande quantidade de cenários com variações paramétricas, expondo a influência de cada parâmetro nas deformações da estrutura e na solicitação do reforço. A partir dos resultados obtidos os autores geraram ábacos e curvas de interpolação para prever o deslocamento máximo na face, a deformação horizontal máxima e o fator de segurança em MSRG.

Ambos os métodos devem ser utilizados com cautela se o que se pretende analisar é o que ocorre na estrutura após o término da construção, pois não se pode adotar que a deformação obtida inicialmente se mantenha igual ao longo da vida útil da estrutura. Para os efeitos de fluência do geossintético ao longo do tempo devem ser utilizados métodos específicos, como o de Sawick (1999). Modelagens numéricas que desconsideram a fluência do reforço representam temporalmente apenas a deformada no momento do término da construção do muro.

\subsubsection{Geossintéticos utilizados como reforços}

Geossintéticos são materiais poliméricos utilizados em diversas aplicações na engenharia geotécnica, inclusive como reforços em muros de solo reforçado. A origem morfológica vem da contração do prefixo "geo", referindo-se a terra, com o sufixo referente a "sintéticos", relacionando-se com a matéria prima com que são feitos (polímeros). A Associação Brasileira de Normas Técnicas (ABNT), na norma NBR ISO 10318:2013, define geossintéticos como "termo genérico designando um produto no qual ao menos um de seus componentes é produzido a partir de um polímero sintético ou natural. Apresenta-se na forma de manta, tira ou estrutura tridimensional, utilizado em contato com o solo ou outros materiais, em aplicações da engenharia geotécnica e civil". Os geossintéticos podem ter outras funções além de reforço, como de separação, filtração, drenagem e barreira impermeável. A viabilização do uso do geossintético de tantas formas se deve ao fato de ser 
possível obter as características desejadas com pequenas modificações no processo de fabricação (KOERNER, 1994).

Os principais geossintéticos utilizados como reforços em MSRG são as geogrelhas e os geotêxteis. Como o próprio nome sugere, geogrelhas são geossintéticos fabricados em formato de grelha, de modo que sua interação com o solo ocorra também pelas aberturas, promovendo o embricamento do solo. As geogrelhas são mais rígidas que os geotêxteis e sua principal função é justamente o reforço de solo.

O geotêxtil é fabricado com outros objetivos além de reforço, como separação e filtragem. É um produto flexível e poroso, com a possibilidade também de ser usado para a drenagem interna de um MSRG (PORTELINHA, 2012). Sua produção se dá como os demais produtos têxteis: a primeira etapa é a fabricação de fios, fibras ou fitas a partir de materiais poliméricos, e a segunda etapa consiste no entrelaçamento dessas fitas de modo a formar uma estrutura no formato de um plano.

O modo como se dá o entrelaçamento das fibras durante a confecção define o tipo de geotêxtil, tecido ou não tecido. O tecido é fabricado de forma que as fibras fiquem alinhadas em duas direções principais, favorecendo a rigidez do material, mas diminuindo a capacidade de drenagem. $O$ não tecido tem na sua fabricação o arranjo das fibras de forma aleatória, o que favorece a capacidade de drenagem, mas diminui sua rigidez. Ao se comparar um geotêxtil tecido com um geotêxtil não tecido, espera-se que o tecido tenha maior rigidez e o não tecido tenha maior capacidade de drenagem.

Para a escolha do melhor tipo de reforço a ser empregado em um MSRG deve ser avaliado o local, o tipo de solo e as dimensões do muro, pois em cada situação determinados tipos de reforços são economicamente mais interessantes que outros. Para Benjamin (2006), muros de até $4 \mathrm{~m}$ de altura construídos com geogrelhas apresentam um custo mais elevado do que com geotêxtil. Embora os geotêxteis geralmente resultem em MSRGs de menor custo, apresentam limitação de resistência e rigidez. 
As deformações do MSRG são influenciadas pelo tipo de solo e de reforço, mais especificamente pela rigidez do reforço e pela resistência ao cisalhamento e rigidez do solo. Helwany; Reardon e Wu (1999) observaram por meio de simulações numéricas que quanto mais rígido é o reforço, menor é a deformação necessária para que seja atingida a estabilidade do muro. Na Figura 2.3 é possível observar essa influência da rigidez do reforço nas deformações internas do muro de solo reforçado.

Figura 2.3 - Curva de compatibilidade solo-reforço

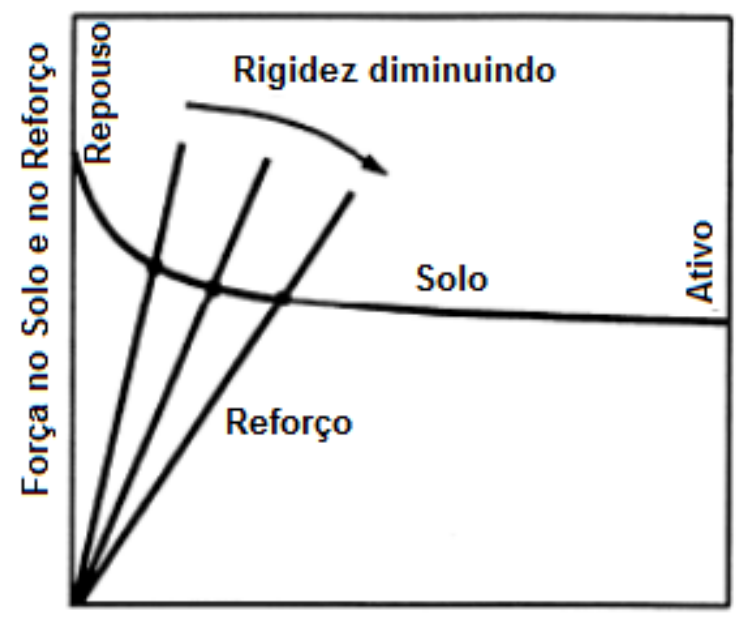

Deformação Específica

Fonte: Jewell (1990)

Na Figura 2.3 é possível observar que reforços mais rígidos, mesmo com deformações menores, absorvem mais carga em relação a reforços com menor rigidez. Quanto às características do solo empregado, maior rigidez e maior resistência ao cisalhamento acarretam em menor deformação interna, porém o valor dessa contribuição é mais complexo de ser calculado.

\subsubsection{Interação entre solo e geossintético}

Embora métodos analíticos e numéricos muitas vezes partam da hipótese de perfeita interação entre solo e reforço, isso não ocorre em algumas combinações de solo, reforço e tensões de confinamento. Essa interação depende de uma série de fatores, que no caso das geogrelhas é o atrito lateral nos elementos longitudinais da geogrelha, o embricamento do solo preso nos vazios da geogrelha e a resistência passiva contra os elementos transversais (EHRLICH; BECKER, 2009). Caso a 
tensão solicitada seja maior que a aderência com o reforço, ocorrerá ruptura por arrancamento no MSRG.

Para saber a intensidade da interação entre solo e geogrelha é necessário realizar ensaios laboratoriais, entre os quais o mais utilizado é o ensaio de arrancamento. $O$ ensaio de arrancamento é considerado por muitos pesquisadores 0 mais apropriado para a previsão da resistência de interface solo-inclusão (FARRAG; ACAR; JURAN, 1993). Neste ensaio monta-se um protótipo de solo reforçado com carga de confinamento e submete-se o geossintético à tração. Com esta relação é possível obter um dos parâmetros necessários ao dimensionamento de um muro reforçado, ou seja, o de carga de ruptura por arrancamento dos reforços, assim como curvas de deslocamento em função da força de arrancamento aplicada.

Pesquisas mostraram que algumas adaptações no ensaio de arrancamento podem representar de forma mais realista a interação entre o solo e o reforço. Abramento (1993) destaca a importância de o ensaio ser feito em forma de carregamento e descarregamento, e de se ter resultados com o geossintético disposto de forma oblíqua às tensões aplicadas durante o ensaio. Dessa forma, pode-se avaliar a interação entre o geossintético e o solo em diversas camadas e profundidades de um MSRG, pois há a variação da magnitude e da direção das tensões na massa de solo reforçado.

Kakuda (2005) elaborou um equipamento de arrancamento com menores dimensões e utilizou-o para ensaiar solos finos, visando suprir uma demanda de mercado. Foi observado nesse estudo que solos com teores maiores de argila apresentaram menores valores de resistência ao arrancamento, e que houve menores deslocamentos antes de se atingir a resistência máxima.

Teixeira (2003) obteve as mesmas conclusões realizando uma série de simulações com 4 equipamentos diferentes. A Figura 2.4 mostra a relação entre a resistência ao arrancamento de dois tipos de geogrelhas em função da tensão confinante para três tipos de solo. Observa-se que a interação do solo fino é menor quando comparada a solos mais grosseiros. 
Figura 2.4 - Resistência ao arrancamento de geogrelha em função da tensão confinante para três solos

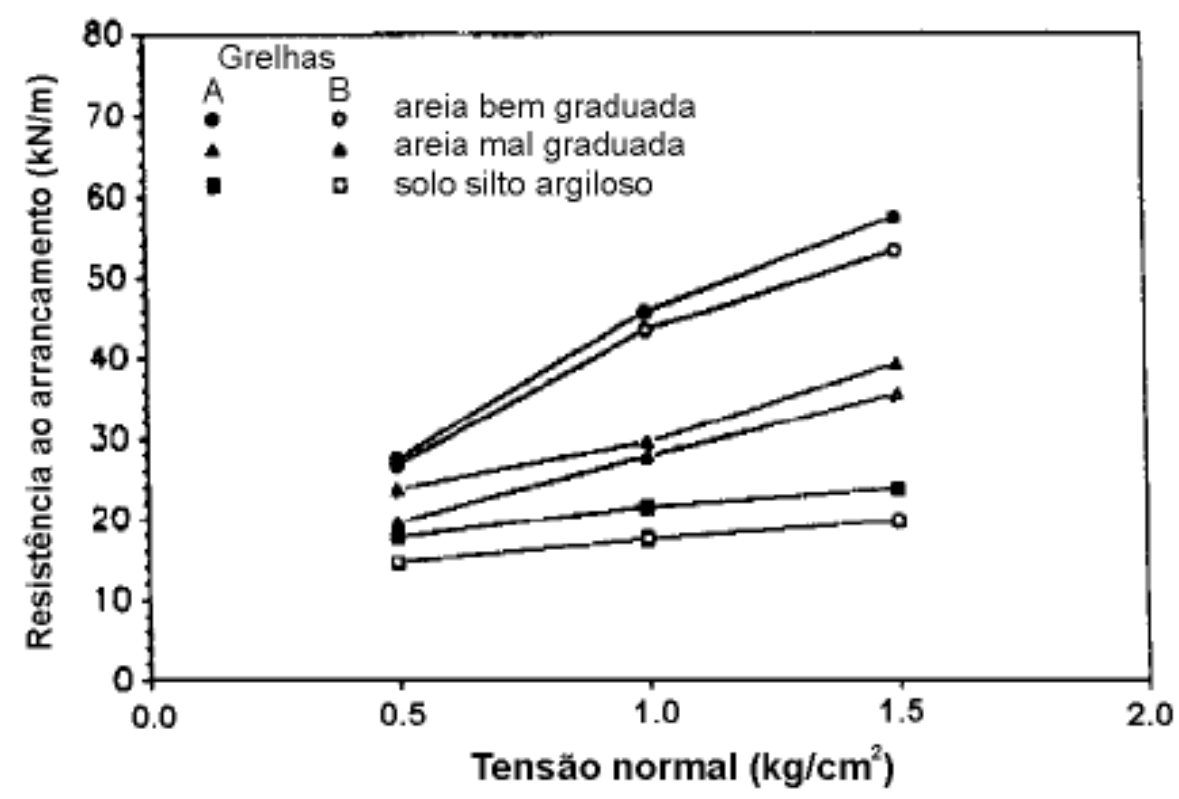

Fonte: Teixeira (2003)

$\mathrm{Na}$ Figura 2.4 é possível observar que as maiores resistências ao arrancamento foram encontradas na areia bem graduada, assim como mais significativo aumento da resistência em função do aumento da tensão normal.

O ensaio de ring shear foi utilizado por Rebelo (2003) para verificar a interação entre o geossintético e dois tipos de solo: uma areia e um solo argiloso. Embora o geossintético estudado neste caso (geomembrana) não seja aplicado com a função de reforço, algumas conclusões podem ser úteis para MSRG: a textura do geossintético e o aumento do grau de saturação do solo tiveram um impacto mais significativo na resistência de interface no solo argiloso em relação ao solo arenoso.

Sobre a resistência de interface, Teixeira (2003) observou que há uma relação quase linear com os seguintes fatores: o comprimento da geogrelha, 0 deslocamento máximo antes da ruptura, a tensão de confinamento e o grau de compactação do solo. Quanto à influência da umidade, o autor destaca que a relação entre tensão de confinamento e resistência ao arrancamento se mantém independente do grau de saturação do solo, um pouco diferente do observado por Rebelo (2003), pois a interação com a geogrelha também se dá pelo embricamento do solo, o que não ocorre com os demais geossintéticos. 
Rebelo (2003) afirma que a resistência ao arrancamento é superior quando há drenos instalados, pois se o solo ficar saturado, em estruturas não drenadas, a sobrecarga acarreta o surgimento de pressões neutras que diminuem a resistência ao arrancamento.

Pode-se extrair dessas pesquisas que a adoção de uma interação (ou aderência) perfeita entre o solo e o reforço na condição de ruptura em modelagens numéricas e análises de MSRG se restringe a casos específicos: quando as tensões de interação são baixas; quando o solo está com baixa umidade ou quando se trata do uso de areias bem graduadas no MSRG. Yu; Damians e Bathurst (2015) também chegaram à conclusão que apenas sob determinadas condições ocorre perfeita interação entre o solo e reforço ao analisar diversas metodologias numéricas para simular a interface. Em condições de trabalho, por outro lado, a prática tem mostrado que é aceitável a hipótese de aderência perfeita entre o reforço e o solo (informação verbal) ${ }^{1}$.

\subsubsection{Solos finos aplicados em MSRG}

A utilização de solos finos em muros reforçados ocorre muitas vezes devido a indisponibilidades de solos granulares próximos ao local da obra. Koerner e Koerner (2013) fizeram um levantamento de uma série de estruturas de muro reforçado na América do Norte que tiveram falhas, onde dos 171 casos analisados, 127 sofreram colapsos e 44, deformação excessiva, sendo que $61 \%$ desses muros foram construídos com solos finos. Esses muros haviam sido projetados com o uso de solos granulares, porém foi alterado o tipo de solo devido à indisponibilidade de materiais granulares e a presença de solos finos no local.

O uso de solos finos não significa necessariamente o colapso da estrutura, mas sim que é necessário que o projeto seja dimensionado de acordo e que haja um controle apropriado na execução da obra. O efeito do tipo do solo no comportamento de MSRG também se deve à perda de resistência pela presença da água no solo, que é mais intenso em solos finos, por apresentarem menor permeabilidade em

\footnotetext{
${ }^{1}$ Comunicação pessoal do Dr. Paulo Brugger durante a defesa deste mestrado ocorrida na Escola Politécnica da Universidade de São Paulo, São Paulo, em 05 de agosto de 2016.
} 
relação aos solos granulares. A água é responsável pelo alívio da tensão efetiva caso ocorra a saturação ou aumento de umidade.

Normas internacionais, em geral, restringem o uso de solos finos em MSRG, conforme observado na Tabela 2.1 .

Tabela 2.1 - Especificações de solos para MSRGs em diferentes países

\begin{tabular}{|c|c|c|c|}
\hline País & Agência & Granulometria Requerida & $\begin{array}{l}\text { Coesão } \\
\text { Máxima }\end{array}$ \\
\hline Alemanha & EBGEO (1997) & Não mais que $12 \%$ de finos & $0 \mathrm{kPa}$ \\
\hline Austrália & RTA (1997) & $\begin{array}{l}\text { Até } 15 \% \text { passante na peneira } \\
0,075 \mathrm{~mm}\end{array}$ & $0 \mathrm{kPa}$ \\
\hline Brasil & GeoRio (1999) & $\begin{array}{l}\text { Até } 10 \% \text { passante na peneira } \\
0,075 \mathrm{~mm}\end{array}$ & $0 \mathrm{kPa}$ \\
\hline Canadá & $\begin{array}{l}\text { Canadian Geotechnical } \\
\text { Society (1992) }\end{array}$ & Não mais que $30 \%$ de finos & $\begin{array}{l}\text { Especificar } \\
\text { no projeto }\end{array}$ \\
\hline Hong Kong & GEO (1993) & $\mathrm{n} / \mathrm{a}$ & $\begin{array}{l}\text { O kPa- } \\
\text { Perm. 50\% } \\
\text { - Temp. }\end{array}$ \\
\hline Itália & $\begin{array}{l}\text { Italian Ministry of Public } \\
\text { Works (1988) }\end{array}$ & $\begin{array}{c}\text { Resistência do solo deve } \\
\text { apresentar parcelas de atrito e } \\
\text { de coesão }\end{array}$ & $0 \mathrm{kPa}$ \\
\hline UK & BS 8006 (1995) & $\begin{array}{l}\text { Até } 10 \% \text { passante na peneira } \\
63 \mu \mathrm{m}\end{array}$ & $5 \mathrm{kPa}$ \\
\hline \multirow[b]{2}{*}{ US } & $\begin{array}{c}\text { AASHTO (2002) FHWA } \\
(1998)\end{array}$ & $\begin{array}{c}\text { Até } 15 \% \text { passante na peneira } \\
0,075 \mathrm{~mm}\end{array}$ & $0 \mathrm{kPa}$ \\
\hline & NCMA (1998) & $\begin{array}{c}\text { Até } 35 \% \text { passante na peneira } \\
0,075 \mathrm{~mm}\end{array}$ & $0 \mathrm{kPa}$ \\
\hline
\end{tabular}

Fonte: (adaptado de ZORNBERG; LESHCHINSKY, 2003)

Isso ocorre porque as normas foram elaboradas em países cujos solos finos foram originados pelo intemperismo de clima temperado, que geralmente forma solos finos com parâmetros de resistência inferiores aos solos finos formados em clima tropical. A melhor qualidade dos solos tropicais já foi constatada pela engenharia nacional, tanto que diversos MSRG com solos ditos inapropriados pelas normas internacionais foram construídos com sucesso no Brasil.

Solos finos tropicais podem apresentar um bom comportamento, principalmente quando são solos residuais tropicais (lateríticos) que apresentam elevada resistência ao cisalhamento (coesão e ângulo de atrito) e baixa compressibilidade. Nogami e Villibor (1995) apontam que não é adequado o uso dos sistemas internacionais tradicionais de classificação de solos no Brasil, pois os solos tropicais apresentam uma série de peculiaridades não contempladas pelas normas 
internacionais. Ehrlich (1995) observou que solos residuais tropicais de rochas graníticas ou de gnaisses apresentam excelentes características mecânicas mesmo quando há elevado percentual de finos.

Ehrlich e Becker (2009) mostraram que é possível o dimensionamento de MSRG com o uso de solos finos tropicais, os quais têm parâmetros de resistência (coesão e angulo de atrito) e de rigidez superiores aos de solos de finos temperados (descartados pelas normas internacionais). Os autores disponibilizam tais parâmetros para dimensionamento, alertando que são valores conservadores, uma vez que há uma grande dispersão de valores para todo o universo dos solos finos tropicais. Para um dimensionamento mais econômico, é aconselhado realizar ensaios com o solo a ser utilizado e o reforço proposto.

Benjamim (2006) fez um levantamento sobre deslocamentos em 30 muros reforçados em diversas localidades do mundo, com diferentes solos e materiais de reforço. A Tabela 2.2 mostra a deformação máxima (alongamento do reforço) sofrida para cada um dos 30 muros reforçados levantados na literatura pelo autor. Observase que MSRG com solos que contêm finos apresentam deformações da mesma ordem de grandeza do que outros com solos granulares.

Tabela 2.2 - Comportamento de muros reforçados utilizando materiais

\begin{tabular}{|c|c|c|c|c|}
\hline Muro & Tipo de Solo & Tipo de Geossintético & $\begin{array}{c}\text { Deformação } \\
\text { Máxima no } \\
\text { reforço }\end{array}$ & Condição \\
\hline 1 & Areia Siltosa & Geotêxtil não tecido (PP) & $3 \%$ & Ruptura \\
\hline 2 & Pedregulho Argiloso & Geogrelha (PEAD) & $4 \%$ & Ruptura \\
\hline 3 & Areia & Geogrelha/tela soldada & $30 \%$ & Ruptura \\
\hline 4 & Areia de praia & Geogrelha (PP) & $0,60 \%$ & Trabalho \\
\hline 5 & Areia Siltosa & Geogrelha (PEAD) & $1,20 \%$ & Trabalho \\
\hline 6 & Areia Argilosa & Geogrelha (PET) & $0,80 \%$ & Trabalho \\
\hline 7 & Areia com pedregulho & Geotêxtil tecido & $0,50 \%$ & Trabalho \\
\hline 8 & Sem referência & Geogrelha (PEAD) & $1,00 \%$ & Trabalho \\
\hline 9 & Areia com pedregulho & Geogrelha (PEAD) & Não & Trabalho \\
\hline 10 & Solo Arenstrumentada & Geogrelha (PEAD) & $1,00 \%$ & Trabalho \\
\hline 11 & Areia & Geogrelha (PEAD) & $0,33 \%$ & Trabalho \\
\hline 12 & Solo Granular & Geogrelha (PEAD) & $0,30 \%$ & Trabalho \\
\hline 13 & Areia com pedregulho & Geogrelha (PEAD) & $1,00 \%$ & Trabalho \\
\hline 14 & Areia bem graduada & Geogrelha (PEAD) & $0,40 \%$ & Trabalho \\
\hline 15 & Talus & Geotextil tecido & Não & Trabalho \\
\hline 16 & Argila Inorgânica & Geogrelha (PEAD) & $1,80 \%$ & Fase \\
\hline
\end{tabular}




\begin{tabular}{|c|c|c|c|c|}
\hline & & & & Construtiva \\
\hline 17 & Silte Argiloso & Geogrelha (PEAD) & $2,00 \%$ & $\begin{array}{c}\text { Fase } \\
\text { Construtiva }\end{array}$ \\
\hline 18 & Areia Argilosa & Geogrelha & $\begin{array}{c}\text { Não } \\
\text { instrumentada }\end{array}$ & Trabalho \\
\hline 19 & Granito Decomposto & $\begin{array}{c}\text { Geotêxtil não } \\
\text { tecido+composto }\end{array}$ & $0,20 \%$ & Trabalho \\
\hline 20 & Areia & Geogrelha (PEAD) & $18 \%$ & Ruptura \\
\hline 21 & Areia Média & Geogrelha (PEAD) & $0,80 \%$ & Trabalho \\
\hline 22 & Argila Siltosa & Geotêxtil não tecido (PET) & $\begin{array}{c}\text { Não } \\
\text { instrumentada }\end{array}$ & Trabalho \\
\hline 23 & Areia Silto-Argilosa & $\begin{array}{l}\text { Geotêxtil tecido e não } \\
\text { tecido }\end{array}$ & $\begin{array}{c}\text { Não } \\
\text { instrumentada }\end{array}$ & Trabalho \\
\hline 24 & Areia com pedregulho & Geogrelha & $2,00 \%$ & $\begin{array}{c}\text { Ruptura } \\
\text { com } \\
\text { Sobrecarga } \\
965 \mathrm{KN}\end{array}$ \\
\hline 25 & Areia com pedregulho & Geogrelha & $0,95 \%$ & Trabalho \\
\hline 26 & Areia Grossa & Geogrelha (PEAD) & $3,50 \%$ & $\begin{array}{l}\text { Trabalho } \\
\text { após } \\
\text { descongela } \\
\text { mento do } \\
\text { solo }\end{array}$ \\
\hline 27 & Argila Arenosa & Geotêxtil não tecido (PET) & - & Trabalho \\
\hline 28 & Xisto Argiloso & Geogrelha (PEAD) & $0,40 \%$ & Trabalho \\
\hline 29 & Argila Siltosa & Geotêxtil não tecido (PET) & $\begin{array}{c}\text { Não } \\
\text { instrumentada }\end{array}$ & Trabalho \\
\hline 30 & Argila Siltosa & Geogrelha (PEAD) & $\begin{array}{c}\text { Não } \\
\text { instrumentada }\end{array}$ & Trabalho \\
\hline
\end{tabular}

PP: polipropileno; PEAD: polietileno de alta densidade, e PET: polietileno tereftalato Fonte: Adaptado de Benjamim (2006)

De fato, a utilização de solos finos em MSRGs vem se mostrando possível. O'Kelly e Naughtn (2008) realizaram ensaios laboratoriais de solo reforçado com uma argila marrom pedregulhosa de baixa plasticidade de Dublin, Irlanda, reforçada com uma geogrelha diferenciada que possibilitava a drenagem. $O$ uso de solos finos (pouco permeáveis) em MSRGs submetidos ao umedecimento pode resultar em uma ruptura da estrutura por perda da força de interação entre solo e reforço. Os autores mostraram, porém, que o uso da geogrelha drenante acarretou um acréscimo na resistência de interface de 20 a 30\% em relação às geogrelhas tradicionais em situações não drenadas, possibilitando a construção de MSRG com o solo estudado.

Noorzad e Mirmoradi (2010) estudaram como reforço para MSRG construído com solos finos o geotêxtil não-tecido, geossintético que tende a ter uma rigidez menor que a geogrelha, mas que possui boa aderência com o solo fino e favorece $o$ 
controle de umidade no interior da estrutura. Os autores realizaram ensaios triaxiais UU (não consolidados não drenados) com dois solos argilosos do Norte do Irã (CL e $\mathrm{CH}$ ) com diferentes configurações geométricas do reforço. Observou-se, ao se comparar amostras com e sem reforços, que sempre um teor de umidade maior acarreta queda na resistência máxima. Porém, há um ganho de resistência devido ao uso do reforço, o qual é proporcional à sua capacidade de drenagem em condições de elevada umidade.

Portelinha (2012) também comprovou a eficiência do uso de solos finos em MSRG utilizando geotêxtil como reforço. O conteúdo de seu estudo está detalhado em capítulos posteriores, uma vez que esta pesquisa utilizou seus resultados.

Carlos; Pinho-Lopes e Lopes (2016) identificaram a utilização de geocompostos (produtos fabricados pela união de diferentes tipos de geossintéticos) para reforçar o MSRG como uma solução interessante, por possuir a função de drenagem, resistência e aderência simultaneamente. Esse estudo baseou-se em ensaios CBR (Índice de Suporte Califórnia) realizados em amostras de solo siltoarenoso (ML) de Aveiro, Portugal, reforçado com um geocomposto constituído por geotêxtil não-tecido e fibras de poliéster de alta tenacidade. Observou-se que quanto maior a quantidade de reforço da amostra, maior era a sua resistência, porém essa amostra tornava-se mais deformável (menos rígida), uma vez que o geocomposto era mais deformável que o solo.

A importância da utilização de solos finos em MSRG pode ser atestada pela presença de ábaco de dimensionamento considerando a coesão no Manual Brasileiro de Geossintéticos (VERTEMATTI, 2016).

\subsection{MODELOS FÍSICOS DE MSRG}

Para compreender as relações envolvidas na dinâmica do comportamento de obras de terra, algumas vezes é necessária a construção de modelos físicos em laboratório ou a instrumentação de obras reais. Esse conceito vem sendo utilizado em MSRG tanto viabilizar novas técnicas, quanto para desenvolver métodos de dimensionamento. Diante de sua relevância, nesse item serão abordadas pesquisas que utilizaram modelos físicos de MSRG. 


\subsubsection{Monitoramento de MSRG}

Uma maneira de estudar o comportamento de uma estrutura real de MSRG é realizar o seu monitoramento. Por exemplo, Yang et al. (2010) instalaram leitores de carga e deslocamento no interior de um MSRG construído com argila de baixa plasticidade e face de sacos preenchidos com pedregulho ao longo da linha ferroviária chinesa Gan (Zhou)-Long (Yan) a fim de verificar o efeito da vibração. Foram feitas periodicamente leituras dos equipamentos instalados no interior da estrutura e levantamentos topográficos. Na Figura 2.5 são mostradas fotografias do MRSG monitorado no início da operação da ferrovia e um ano e seis meses após.

Figura 2.5- Muro reforçado monitorado

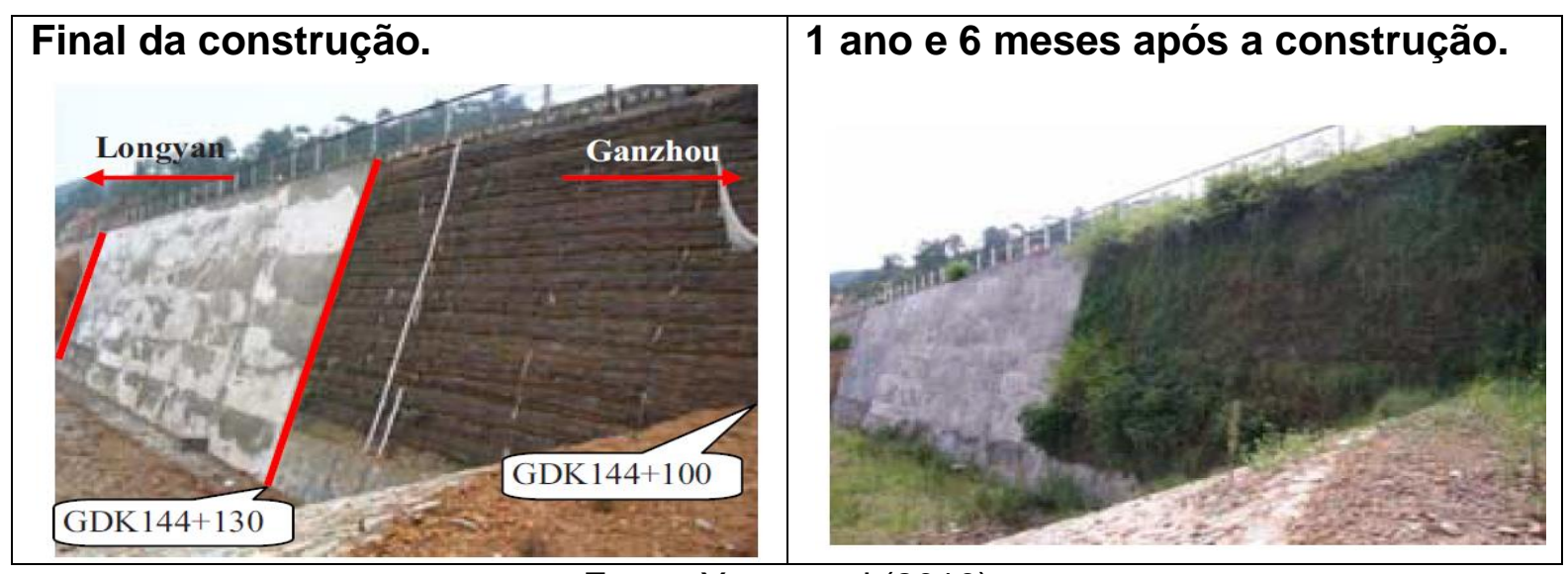

Fonte: Yang et al (2010)

Comparando as imagens não é possível perceber deformações no MSRG, mesmo após um ano e meio de operação. De fato, dificilmente haverá deformações visíveis a olho nu, pois o MSRG possui alta rigidez, o que justifica a instalação de sensores com precisões milimétricas. Porém, pequenos deslocamentos na face e deformações no interior da estrutura são significativos para o entendimento do comportamento da estrutura. $\mathrm{Na}$ Figura 2.6 observam-se os equipamentos instalados no MSRG. 
Figura 2.6 - Equipamentos de leitura de tensão utilizados no monitoramento

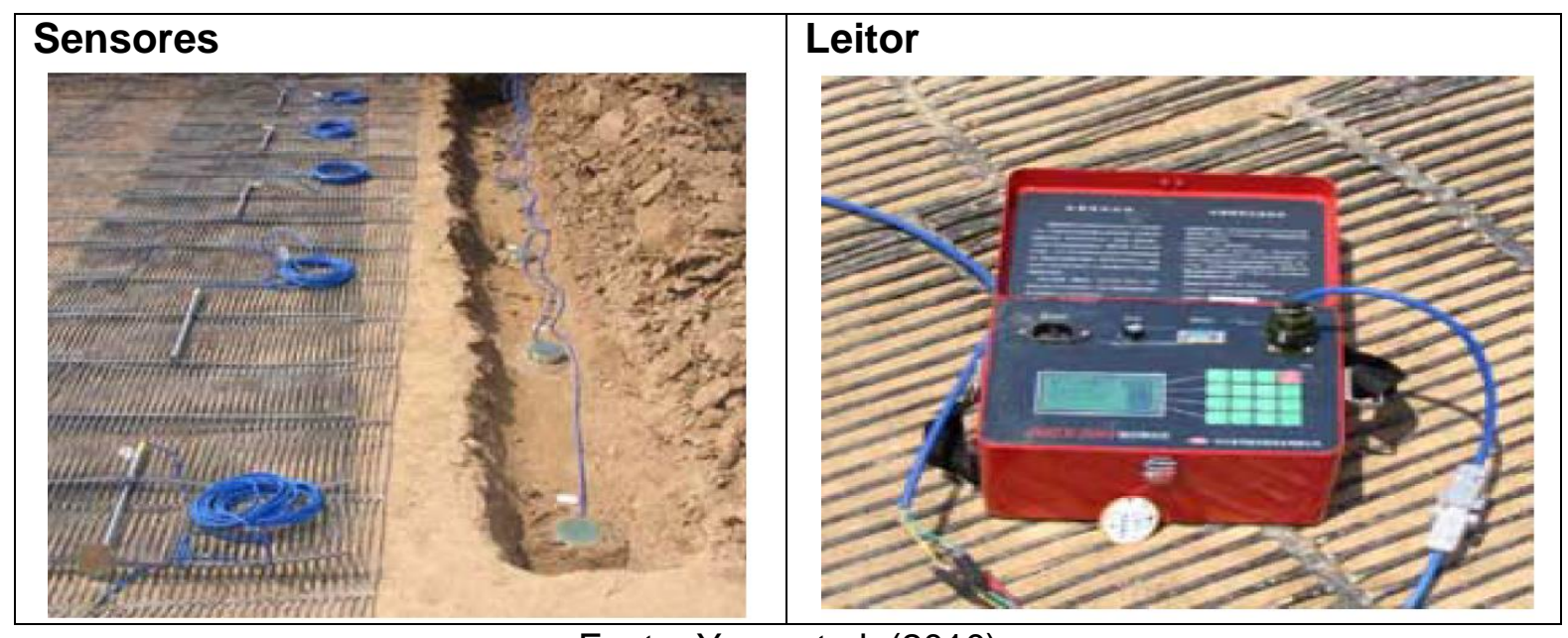

Fonte: Yang et al. (2010)

Observa-se que os sensores de carga foram instalados em contato com o reforço (geogrelha) durante a fase construtiva, com os cabos de transmissão de dados (fio azul) para serem ligados ao receptor após o término da construção. Dessa forma foi possível utilizar uma estrutura real como um modelo físico para estudar o comportamento de um MRSG submetido à vibração. O monitoramento de estruturas reais tem a vantagem de diminuir os custos do modelo físico, pois a construção pode ser paga pelo usuário do MSRG, deixando para a pesquisa apenas o custo dos sensores.

Com o monitoramento da estrutura, especificamente com as leituras das tensões verticais, Yang et al. (2010) observaram que as maiores concentrações de cargas ocorreram no centro da estrutura. Esse comportamento é incomum neste tipo de estrutura, onde a maior solicitação costuma ocorrer próxima à face. Os autores apontaram que o motivo disso foi de o solo ter menor rigidez que o esperado na literatura. Com as leituras da instrumentação os autores também conseguiram comprovar que o MSRG se manteria estável mesmo com uma altura de 25 metros.

Outra instrumentação de MSRG foi realizada por Riccio; Ehrlich e Dias (2014). Construiu-se um muro utilizando solo fino, com geogrelha de poliéster e face de concreto, conforme Figura 2.7. Foram instalados equipamentos para leituras de tensão e deformação no maciço reforçado. O intuito dessa instrumentação foi entender a diferença entre o comportamento de muros reforçados com geossintético ao se utilizar solos finos ao invés de solos granulares. Para tanto as leituras 
realizadas foram comparadas com métodos analíticos e modelagem numérica a fim de se validar equações teóricas. Essa modelagem numérica foi realizada no software de elementos finitos Plaxis 2D, utilizando o estado plano de deformação, com parâmetros de resistência e rigidez de solo obtidos por ensaios laboratoriais.

Figura 2.7 - Modelo físico monitorado

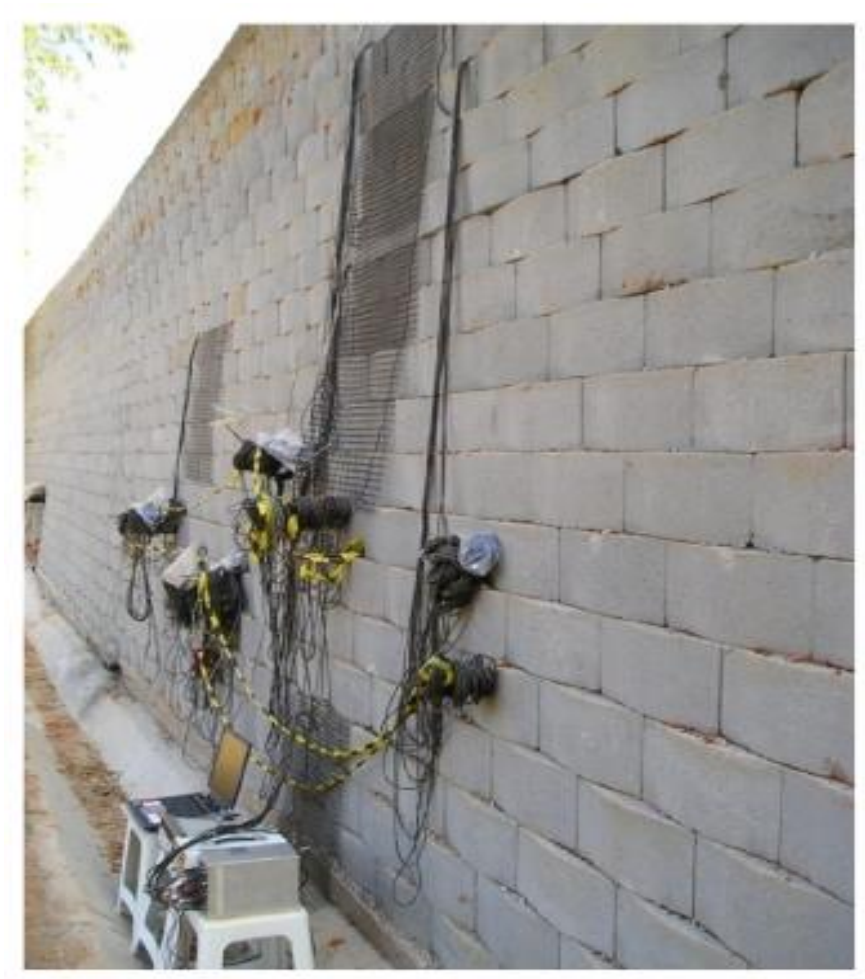

Fonte: Riccio; Ehrlich e Dias (2014)

Pode se observar que trata-se de um MSRG com face rígida em que ocorreram maiores deslocamentos do muro próximos à face (inclinômetros 11) do que os observados na zona de solo não reforçada (inclinômetro I2), superiores no topo do muro do que na base, como mostra a Figura 2.8. A Figura 2.9 mostra as máximas tensões nos reforços, comparando-as com as calculadas pela teoria de Rankine. Os resultados das medições e de campo e calculadas foram muito diferentes devendo-se, porém, ressaltar que o muro encontra-se em condição de trabalho e que a teoria de Rankine se refere à condição de ruptura. 
Figura 2.8- Deslocamentos horizontais medidos pelos inclinômetros no final de construção

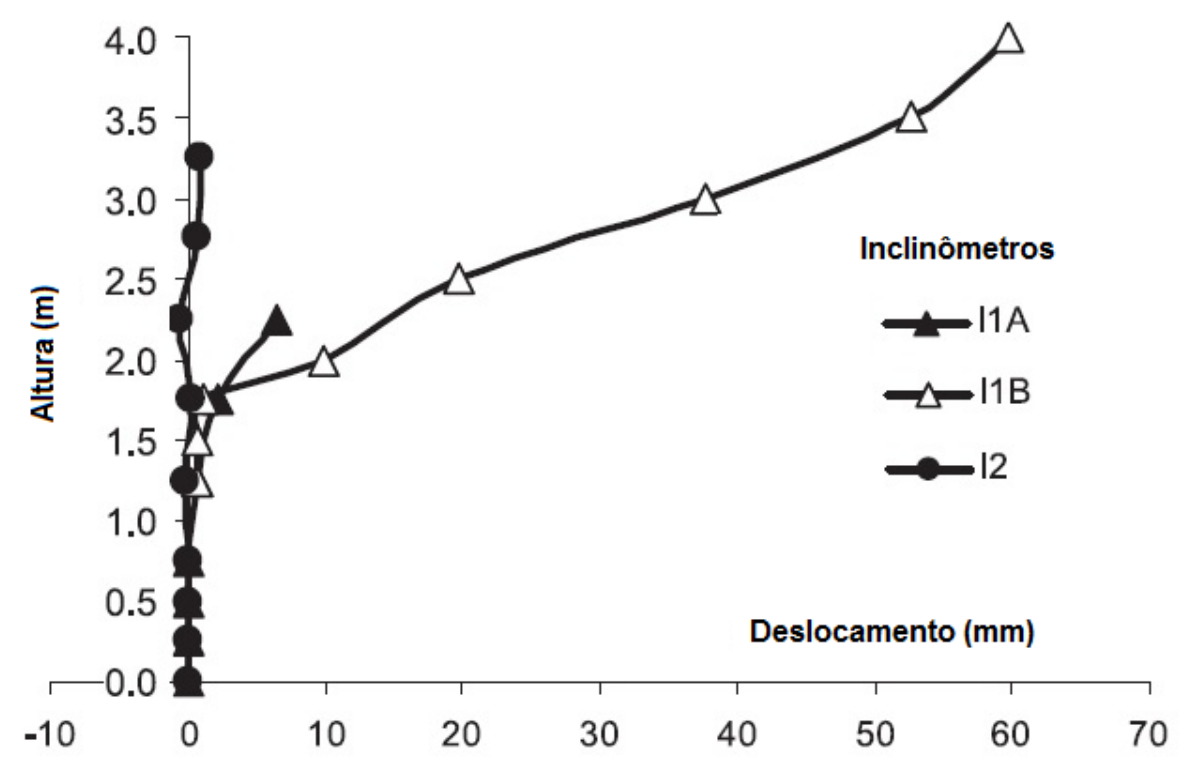

Fonte: Riccio; Ehrlich e Dias (2014)

Figura 2.9 - Localização da máxima tensão nos reforços no final de construção

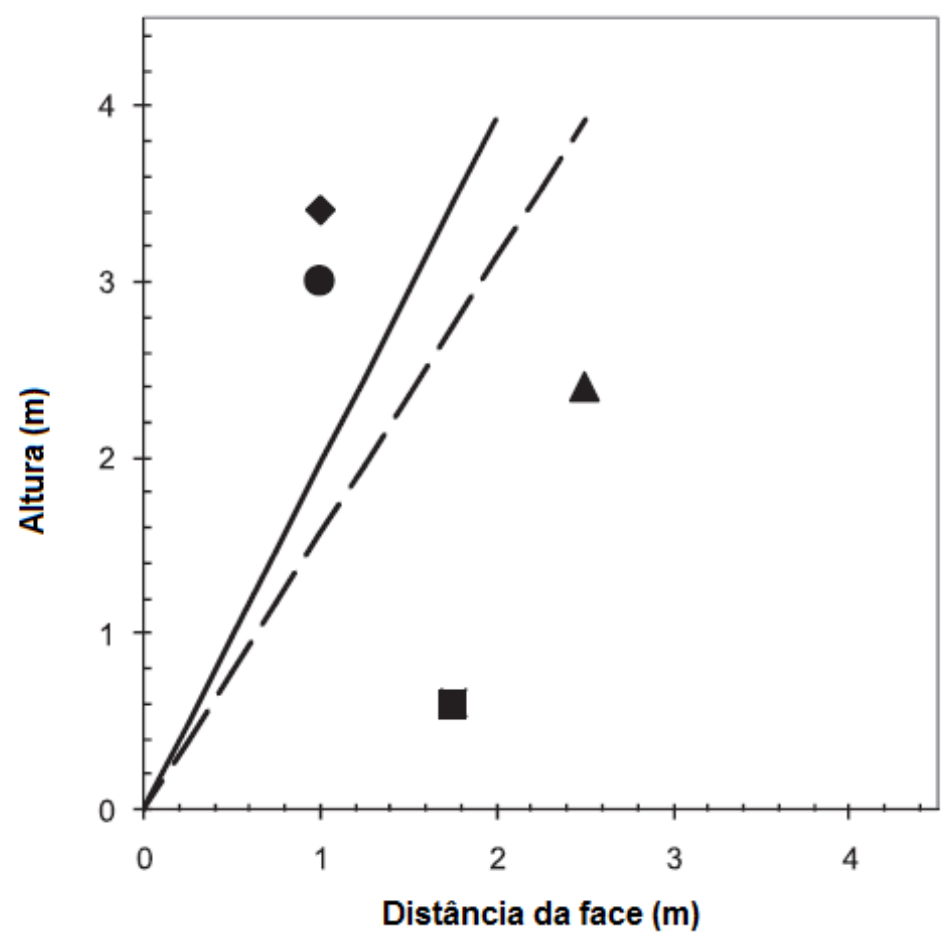

Fonte: Riccio; Ehrlich e Dias (2014)

Portelinha (2012) também instrumentou uma obra de muro reforçado com geossintético, mostrado na Figura 2.10, utilizando uma areia argilosa laterítica. Um 
dos objetivos foi avaliar a diferença no comportamento do muro com a utilização de geotêxtil tecido de maior rigidez e de geotêxtil não tecido. O geotêxtil não tecido possui menor rigidez, mas tem como vantagem uma maior capacidade de drenagem e pode apresentar um menor custo. Foram realizadas leituras das medidas de deslocamentos internos, utilizando extensômetros de hastes metálicas e monitoramento da sucção do solo com o uso de tensiômetro.

Figura 2.10 - Foto do muro reforçado com geotêxtil tecido e não tecido

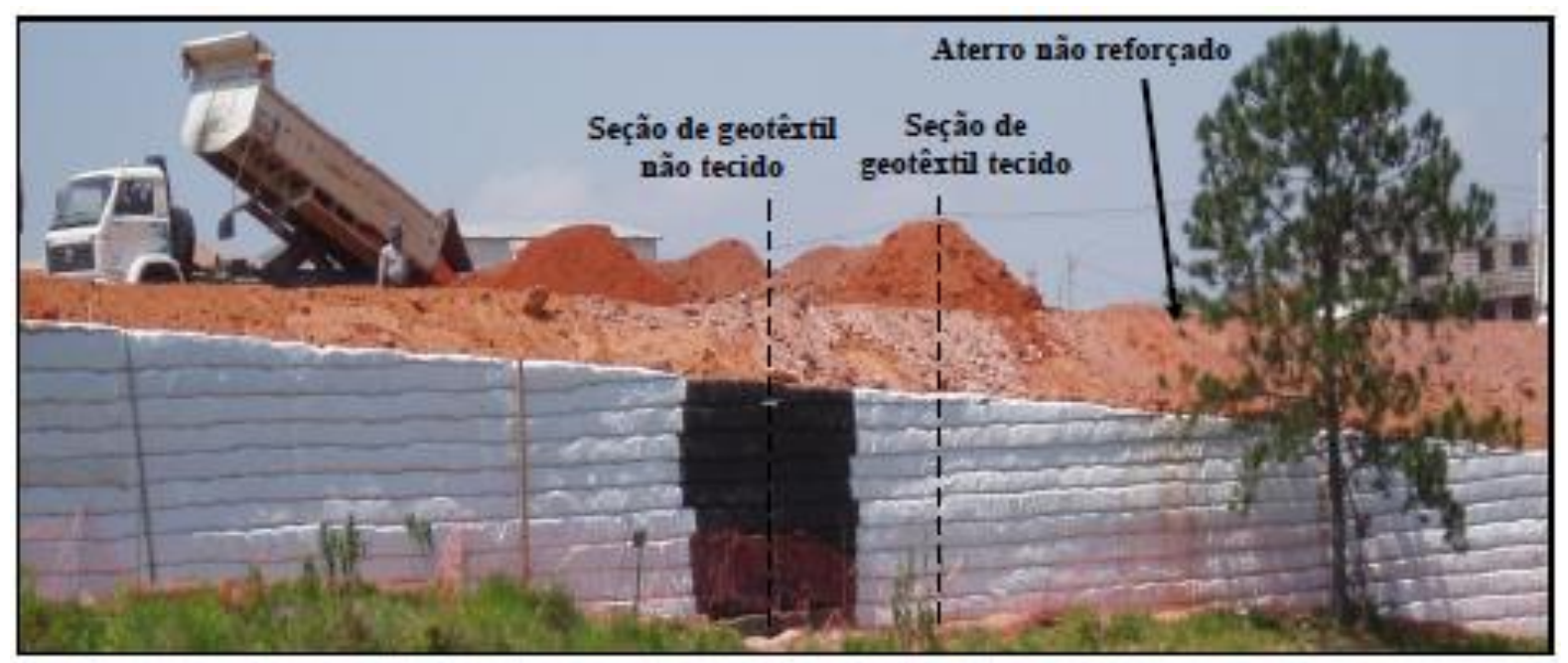

Fonte: Portelinha (2012)

Neste monitoramento foi observado um deslocamento ligeiramente maior no geotêxtil não tecido. Analisando temporalmente durante e após a construção do muro, os maiores deslocamentos ocorreram durante o período construtivo devido ao processo de compactação, sendo estes mais significativos em regiões mais próximas da face. Após o término da construção, o geotêxtil tecido e não tecido apresentaram o mesmo comportamento.

Com as leituras das deformações internas, foi possivel observar a região em que o geossintético era mais solicitado em cada camada. Com esses dados foi possivel obter a potencial superfície de ruptura. A Figura 2.11 mostra a potencial superficie de ruptura obtida no muro de reforço monitorado comparado com superficies de rupturas teóricas encontradas na literatura. 
Figura 2.11 - Potencial superficie de rutura do MSRG com geotêxtil não tecido

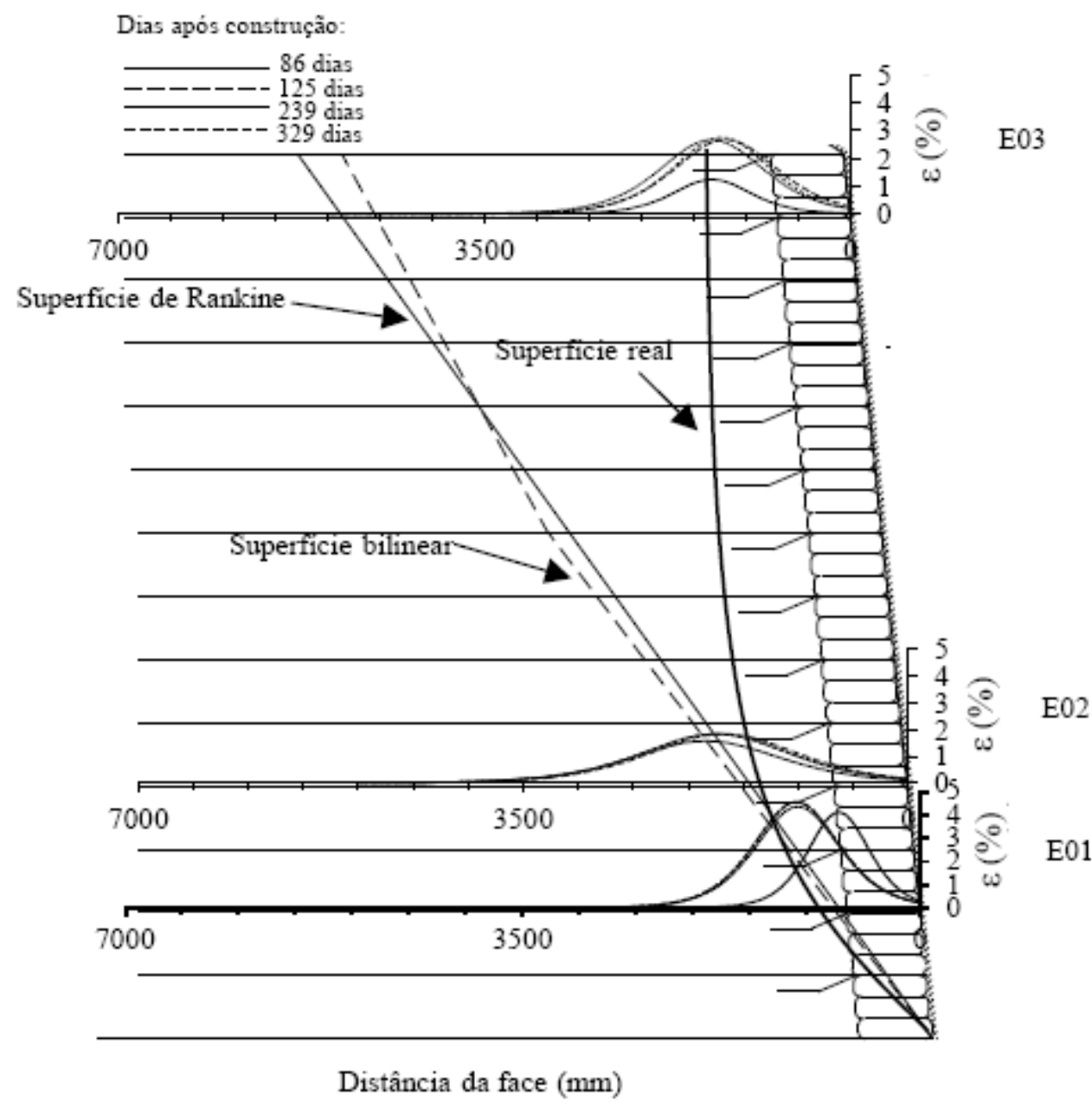

Fonte: Portelinha (2012)

Observa-se que a potencial superfície de ruptura obtida no monitoramento foi bem diferente das calculadas tradicionalmente, no caso a bilinear e a de Rankine. Mais uma vez, a distribuição de tensões nos reforços em um muro em condição de trabalho é diferente da situação de ruptura.

Assim como nas pesquisas de Yang et al. (2010) e de Riccio; Ehrlich e Dias (2014), em Portelinha (2012) foi observada a importância do monitoramento de MSRG construídos, uma vez que MSRG apresentam o comportamento diferente do esperado para muros de contenção sem reforços. Portanto, a utilização de modelos físicos, como o monitoramento de MSRG em campo, é essencial para a compreensão do comportamento de novas estruturas geotécnicas. 


\subsubsection{Protótipos de muros reforçados com geossintéticos}

É comum o uso de modelos físicos representando uma parte de uma estrutura real. Geralmente eles são construídos em laboratório, pois assim podem-se ter condições ambientais controladas; simulações realizadas em um menor período de tempo, e facilidade na instalação da instrumentação e monitoramento. No caso de MSRG, vem sendo muito utilizada a caixa de aço com células de aplicação de carga, como em Saramago (2002), Barboza Júnior (2003), Guedes (2004), Vasconcelos (2010) e Portelinha (2012).

O protótipo tem como objetivo representar uma parte de uma estrutura real de um muro reforçado, conforme exemplificado na Figura 2.12. Para simular o comportamento de um MSRG devido a uma altura maior de muro, é aplicada uma tensão vertical na parte superior do modelo físico, por exemplo, por meio de bolsões de PEAD e compressor de ar, que aplicam uma carga vertical correspondente ao peso do solo. 
Figura 2.12 - Representação do protótipo comparado a um muro reforçado

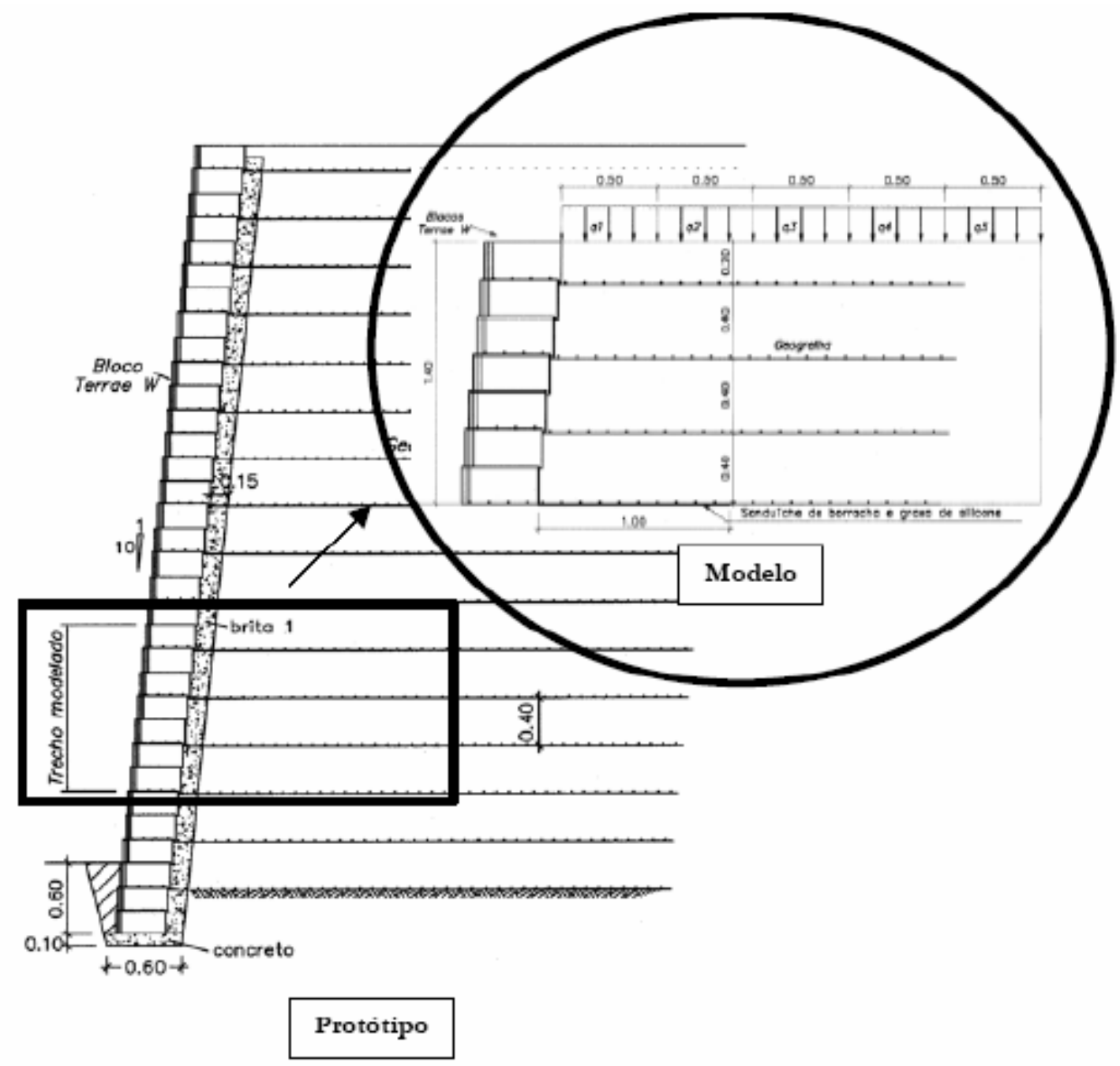

Fonte: Barboza Júnior (2003)

As condições de contorno desse tipo de ensaios não são exatamente iguais às de um MSRG real, pois a restrição ao movimento no topo da caixa devido à célula de carga causa uma interferência nos deslocamentos. Saramago (2002) observou que o protótipo tem uma limitação ao representar uma estrutura real, pois em estruturas com mais de uma determinada altura, a cunha de ruptura interceptaria a caixa metálica do protótipo.

Diversos estudos utilizaram protótipos ou estruturas físicas a fim de verificar o comportamento de diferentes muros, em relação à rigidez da face, ao tipo de solo, ao tipo de inclusão, ao grau de compactação, ao arranjo das inclusões, à altura do muro e à inclinação da face (EHRLICH; MITCHELL, 1994; HELWANY; REARDON; WU, 1999; SARAMAGO, 2002; BARBOZA JÚNIOR, 2003; GUEDES, 2004; 
BENJAMIM, 2006; PALMEIRA, 2009; PEDROSO et al., 2006; EHRLICH; BECKER, 2009; VASCONCELOS, 2010; PORTELINHA, 2012, entre outros).

A seguir será detalhado o modelo físico em laboratório construído por Portelinha (2012) para estudar o comportamento de solos finos tropicais reforçados com geotêxtil, uma vez que seus resultados foram utilizados nesta pesquisa.

A caixa metálica tinha dimensões internas, altura, largura, comprimento, de 1,80 m, 1,65 m, 1,80 m, respectivamente. Foram realizadas leituras de deformações internas e sucção do solo, uma areia argilosa laterítica, conforme eram aplicadas tensões na face superior com o uso da bolsa de ar, cuja técnica é mostrada na Figura 2.13.

Figura 2.13 - Sistema de aplicação de tensões verticais

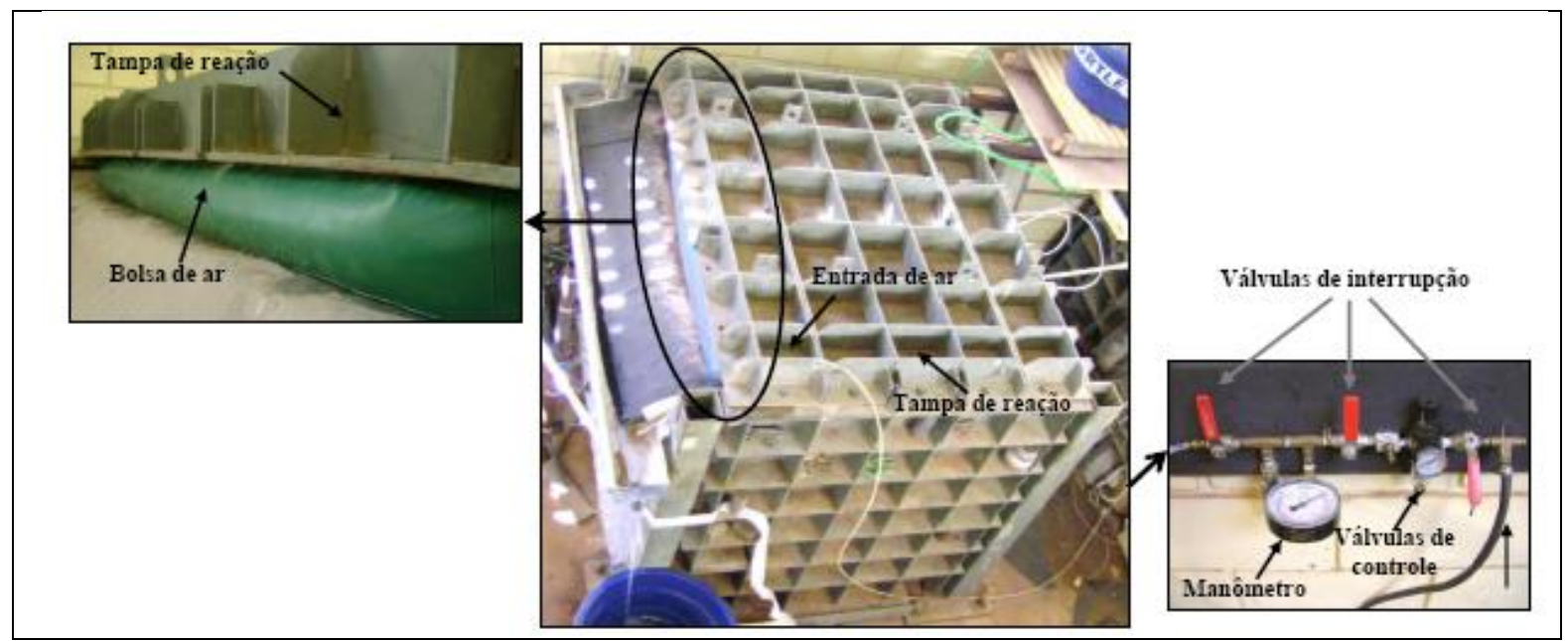

Fonte: Portelinha (2012)

O funcionamento se deu da seguinte forma: o compressor enchia a bolsa de ar, que apoiada na tampa de reação, aplicava a carga no solo, enquanto com o manômetro lia-se a tensão. As paredes e fundo da caixa metálica foram de espessura suficiente para evitar deformações significativas nas laterais da estrutura, de modo que estas fossem irrelevantes diante dos recalques no muro reforçado.

Foram utilizados dois tipos de geossintéticos na montagem dos protótipos, o geotêxteis não tecidos de poliéster (NT-PET), e o geotêxtil não tecido de polipropileno (NT-PP) de maior gramatura. O NT-PP possui maior resistência, como se observa na Figura 2.14, e também maior custo. 
Figura 2.14 - Curvas: Carga x Alongamento

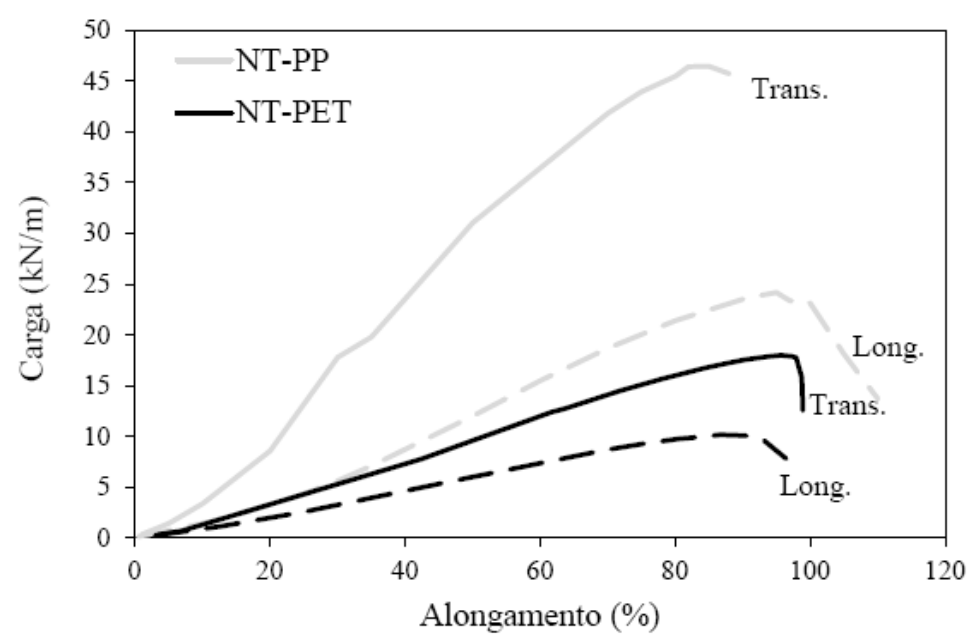

Fonte: Portelinha (2012)

Observa-se que o NT-PP suporta uma carga transversal três vezes maior que o NT-PET. Ambos geotêxteis são não tecidos, técnica de fabricação que acarreta a menor resistência entre os geossintéticos aplicados como reforços, porém têm boa aderência com solos finos e o potencial de funcionar como "tapetes de drenos horizontais". A eficiência como dreno era verificada pela instrumentação de umidade, enquanto a eficiência como reforço era verificada pela instrumentação de tensões e deslocamentos. Na Figura 2.15, observa-se a disposição da instrumentação durante a realização dos ensaios, as dimensões do protótipo e a altura das camadas de reforço. 
Figura 2.15 - Localização da instrumentação no protótipo

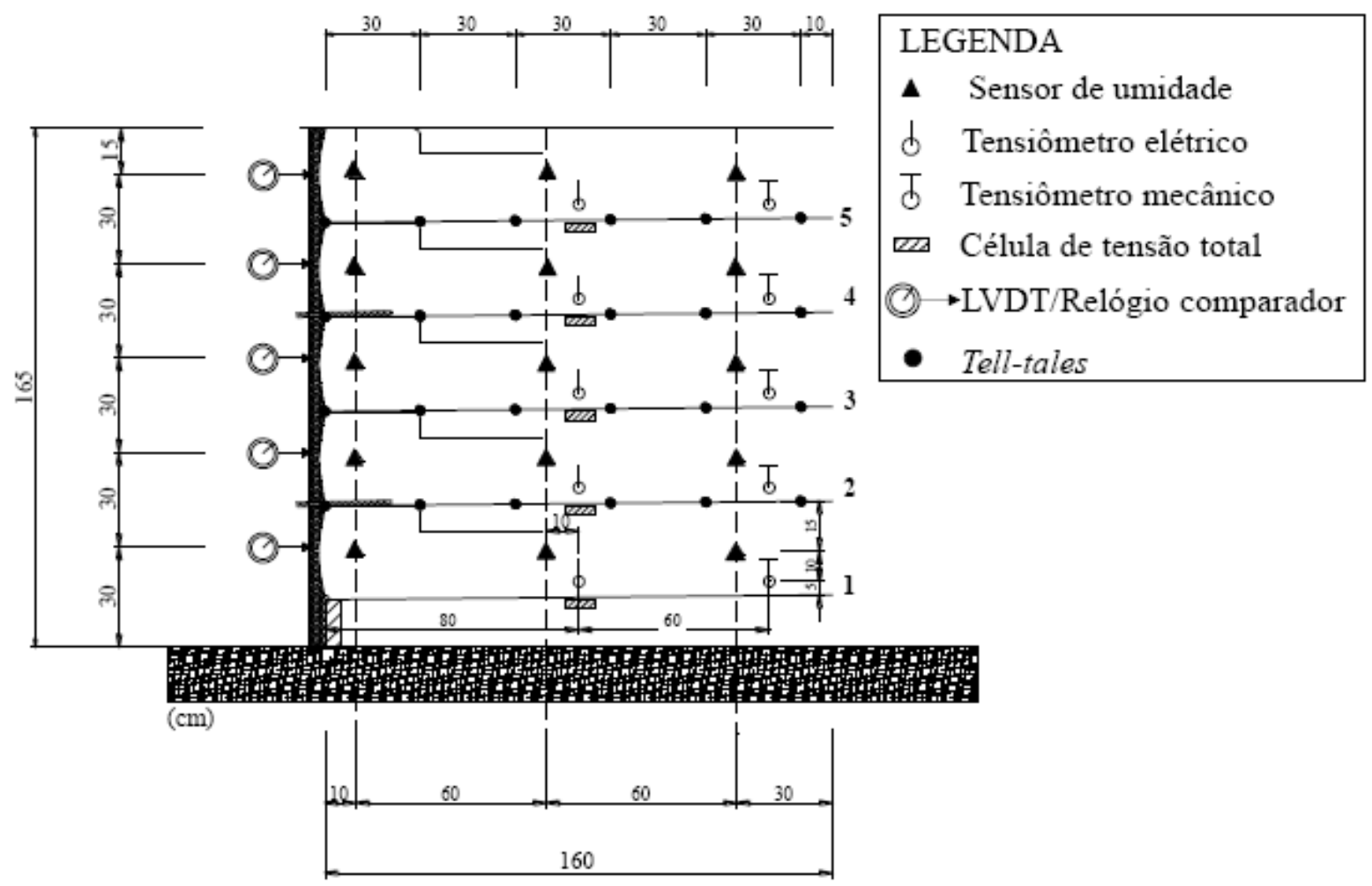

Fonte: Portelinha (2012)

O deslocamento e a sucção foram monitorados em todas as camadas, a fim de verificar a relação entre deformações e umidade. O protótipo foi construído quatro vezes, sempre com a compactação utilizando um peso massa de $15 \mathrm{~kg}$ a uma altura de queda de $60 \mathrm{~cm}$, variando-se a umidade e o tipo de geotêxtil. Foi possível observar a eficiência do geotêxtil não tecido no desempenho do MSRG, pois auxiliou na estabilidade da estrutura e realizou também a função de drenagem interna.

A Figura 2.16 mostra as tensões verticais medidas ao longo da altura do modelo físico, considerando o período do ensaio e comparada à distribuição teórica. É notado que as tensões variaram ao longo do tempo, sendo que a aplicação da sobrecarga de $100 \mathrm{kPa}$ ocorreu no $3^{\circ}$ dia. 
Figura 2.16- Distribuição de tensões no modelo físico

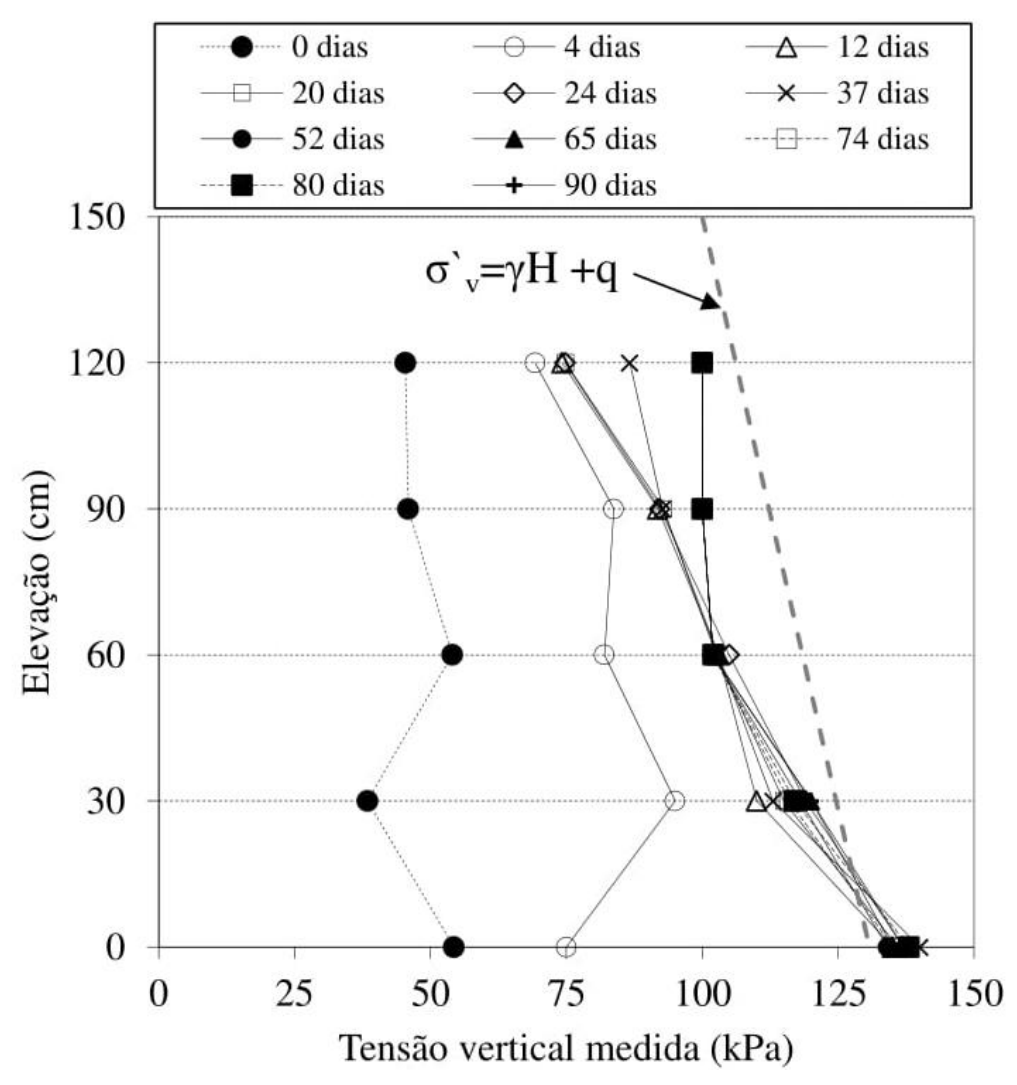

Fonte: Portelinha (2012)

Na Figura 2.17 é mostrado o comportamento do modelo físico ao longo do tempo, expresso pelos deslocamentos horizontais na face, que apresentavam os maiores valores de deslocamentos em relação ao eixo horizontal. 
Figura 2.17- Deslocamentos da face do modelo físico

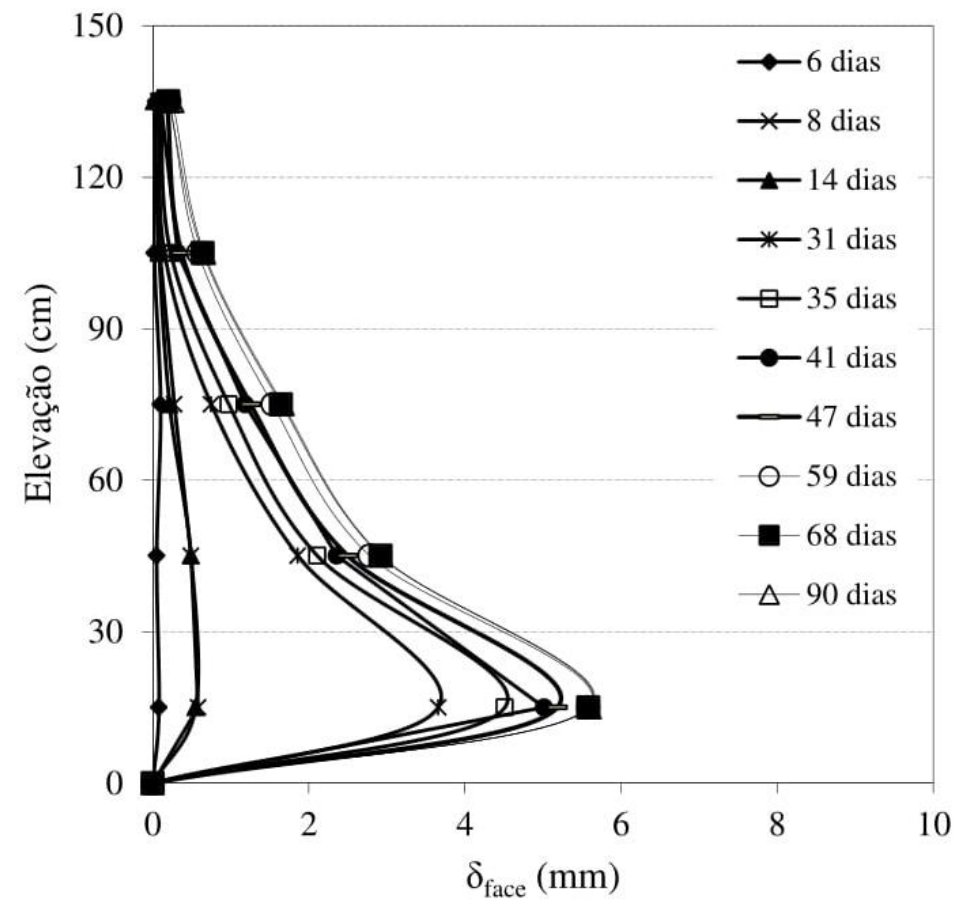

Fonte: Portelinha (2012)

Os estudos em modelos físicos permitem analisar a tendência do comportamento de um MSRG em função de diversos parâmetros relevantes, alguns dos quais serão discutidos a seguir.

\subsubsection{Efeito da configuração do reforço}

As variáveis do reforço que influenciam na estabilidade do MSRG são três: rigidez, espaçamento e comprimento. A rigidez é uma característica diretamente proporcional à resistência do reforço. Entre esses dois parâmetros, a utilização da rigidez é o mais abrangente na análise de estabilidade, pois a resistência do reforço interessa apenas ao se analisar a possibilidade de colapso do MSRG pelo rompimento do reforço, algo raro de acontecer. O espaçamento é uma característica condicionada à rigidez do reforço, pois um reforço de menor rigidez pode ser utilizado se os espaçamentos verticais forem menores. Por fim, o comprimento está condicionado à análise de estabilidade externa, conforme explicado no item 2.1.1.

Oliveira (2006) demonstrou que quanto mais rígido o reforço mais ele contribuirá para a estabilidade. $\mathrm{O}$ autor construiu quatro modelos físicos variando apenas a rigidez do reforço, realizando leituras da tensão nos reforços e da 
movimentação no muro. Para tanto foi utilizada uma caixa de $2 \mathrm{~m}$ de largura, $3 \mathrm{~m}$ de comprimento e 1,5 m de altura, com aplicação de carga na face superior. Esse modelo físico que representa parte de um MSRG, também foi utilizado por Saramago (2002), Barboza Júnior (2003), Guedes (2004) e Vasconcelos (2010). O reforço de rigidez média $(\mathrm{J}=600 \mathrm{kN} / \mathrm{m})$ apresentou tensões mobilizadas superiores ao de menor rigidez $(\mathrm{J}=150 \mathrm{kN} / \mathrm{m})$, mas menores que o reforço mais rígido $(\mathrm{J}=1200$ $\mathrm{kN} / \mathrm{m}$ ). No reforço mais rígido a tensão mobilizada foi a mais alta, inclusive se comparada aos resultados teóricos. O autor observou claramente que há um aumento na resistência do muro com o uso de geossintéticos mais rígidos.

O espaçamento entre os reforços é algo que influencia na estabilidade do muro, porém é uma variável condicionada ao reforço escolhido e a aspectos construtivos. Existe um valor limite o qual pode acarretar rupturas locais. Essas rupturas estão relacionadas à coesão do solo no caso de face exposta, ou às dimensões dos blocos de revestimento, caso seja um MSRG com face. Como blocos grandes são pesados e difíceis de serem manuseados, normalmente é projetado um MSRG com espaçamentos verticais entre 15 a $60 \mathrm{~cm}$. Para tanto a Federal Hightway Administration (FHWA), disponibiliza métodos para o dimensionamento de MSRG, sendo o espaçamento uma variável arbitrada pelo projetista.

Quanto ao comprimento do reforço, o usual é adotar de 70 a $80 \%$ a altura do muro; caso o comprimento ultrapasse essa medida, simplesmente o excedente do reforço não é mobilizado. Ho (1993), que estudou o efeito do comprimento do reforço, percebeu que a simplificação adotada de comprimento de $70 \%$ do valor da altura só é valida quando o ângulo de atrito do solo for igual ou superior a $35^{\circ}$. Portanto, o comprimento do reforço é dependente das características do solo, sendo que a mobilização do reforço se dá principalmente até o local onde ocorre a potencial superfície de ruptura do muro de solo reforçado com geossintético.

Pode-se concluir que dentre as possibilidades de variação no reforço, o que mais interessa a ser estudado é o efeito da rigidez do reforço a ser utilizada, uma vez que o comprimento é uma variável fixada pela estabilidade externa e o espaçamento é uma escolha que envolve os aspectos construtivos. 


\subsubsection{Efeito da variação do tipo de solo e compactação}

As características do solo utilizado no MSRG têm grande influência no seu comportamento. Como a compactação melhora as características do solo, ela melhora a resistência do MSRG, conforme comprovado por Pedroso (2000). Nesse estudo foi verificado que os MSRG com maior grau de compactação apresentaram menores deformações, ou seja, melhor comportamento. O método de Ehrlich e Mitchell (1994) para cálculo das tensões no interior de um muro reforçado dá grande importância à força de compactação aplicada durante a execução, tanto que a tensão na fase de serviço é calculada em função da força aplicada na compactação. Esse método é corroborado por Mirmoradi e Ehrlich (2014), que descrevem como pode ser simulada numericamente a influência da compactação.

Quanto ao tipo de solo, Helwany; Reardon e Wu (1999) apontam que o muro terá maiores deformações e o reforço será mais solicitado quanto menor for a rigidez e a resistência ao cisalhamento do solo. Tal relação também foi observada nos protótipos de Benjamim (2006), que estudou o comportamento de MSRG com solos finos em comparação a solos granulares. Os resultados mostraram que os solos tropicais finos de boa qualidade apresentaram melhor comportamento em relação aos tradicionais solos granulares dos MSRG.

Saramago (2002), Barboza Júnior (2003), Guedes (2004), Oliveira (2006) e Vasconcelos (2010) utilizaram solos granulares em seus ensaios, respeitando a recomendação internacional para MSRG. Com isso garantia-se que o solo teria boa permeabilidade, evitando o surgimento de pressões hidrostáticas no contato do reforço com o solo, que comprometeriam a aderência e poderiam levar a uma ruptura por arrancamento. Para a utilização de solos finos é necessário um sistema de drenagem adequado.

Conclui-se que solos granulares têm como vantagem uma resistência oriunda de um ângulo de atrito elevado e boa capacidade de drenagem. Os solos finos possuem coesão, que ajuda na estabilidade do MSRG, mas apresentam como dificuldades para seu uso a baixa permeabilidade e uma menor aderência ao reforço em algumas combinações. No entanto, adequando-se o projeto a essas dificuldades, é viável utilizar solos finos tropicais em MSRG. 


\subsubsection{Efeito da variação da rigidez e inclinação da face}

O tipo de face de um MSRG impacta tanto no aspecto estético quanto na estabilidade do MSRG. As faces mais rígidas são as de sistemas de blocos segmentais, painéis modulares ou paredes integrais, enquanto as faces mais flexíveis são as do sistema de autoenvelopamento. Ambos os tipo de face têm o seu desempenho condicionado à combinação solo-reforço e à geometria do MSRG.

A contribuição da face rígida pode ser analisada pela leitura da tensão na ancoragem bloco-reforço. Dessa forma, Barboza Júnior (2003) observou que há maior contribuição da face para a estabilidade ao se utilizarem revestimentos de maior rigidez, porém a rigidez da face do muro pode não contribuir significativamente se a mobilização do reforço ocorrer no interior do maciço.

A mesma conclusão foi observada por Guler; Hamderi e Demirkan (2007), que analisaram uma grande diversidade de muros reforçados quanto a sua estabilidade e contribuição da face. Verificou-se que as cargas máximas de tração nas camadas de reforço, no final da fase de construção, estavam no intervalo de 5 a $15 \mathrm{kN} / \mathrm{m}$, porém variavam de posição devido às características do solo e do reforço, e ao procedimento construtivo. Para exemplificar essa proporção, a Tabela 2.3 mostra os resultados obtidos de um dos modelos estudados com suas cargas de tração máximas calculadas.

Tabela 2.3 - Cargas de tração em camadas de reforço

\begin{tabular}{|c|c|c|c|}
\hline № reforço & Carregamento* $^{*}(\mathbf{k N})$ & Distância da face $\mathbf{( m )}$ & Carregamento $^{\text {** }} \mathbf{( k N )}$ \\
\hline 9 & 4,0 & 5,5 & 2,8 \\
\hline 8 & 5,9 & 5,5 & 2,8 \\
\hline 7 & 10,5 & 4,5 & 5,9 \\
\hline 6 & 12,1 & 4,0 & 7,6 \\
\hline 5 & 12,7 & 2,5 & 9,0 \\
\hline 4 & 13,2 & 2,5 & 10,2 \\
\hline 3 & 13,4 & 1,5 & 10,7 \\
\hline 2 & 8,9 & 1,5 & 7,9 \\
\hline 1 & 3,5 & 1,0 & 7,0 \\
\hline
\end{tabular}

${ }^{*}$ Tração de pico imediatamente atrás dos blocos

**Tração de pico no comprimento restante

Fonte: Adaptado de Guler; Hamderi e Demirkan (2007)

O reforço de número 1 representa a camada mais baixa do MSRG. Analisando-a, é possível observar que nos reforços de número 8 e 9 a face não é 
tão solicitada quanto nas camadas mais baixas, onde a carga máxima se localiza a menor distância da face. Portanto, dependendo da camada do MSRG a ser analisada e da configuração do MSRG, a mobilização da face ocorrerá de forma distinta, podendo-se concluir apenas que há uma tendência de maior contribuição da face quando ela for mais rígida.

No caso da construção de muros reforçados através do método de envelopamento, é importante como é feita a ancoragem do geossintético no solo. Lajevardi; Briançon e Dias (2014) confirmaram isso ao estudar o comportamento do reforço de acordo com o tipo de ancoragem. Na Figura 2.18 são mostrados os principais tipos de ancoragens utilizadas.

Figura 2.18 - Diferentes técnicas de amarração do reforço
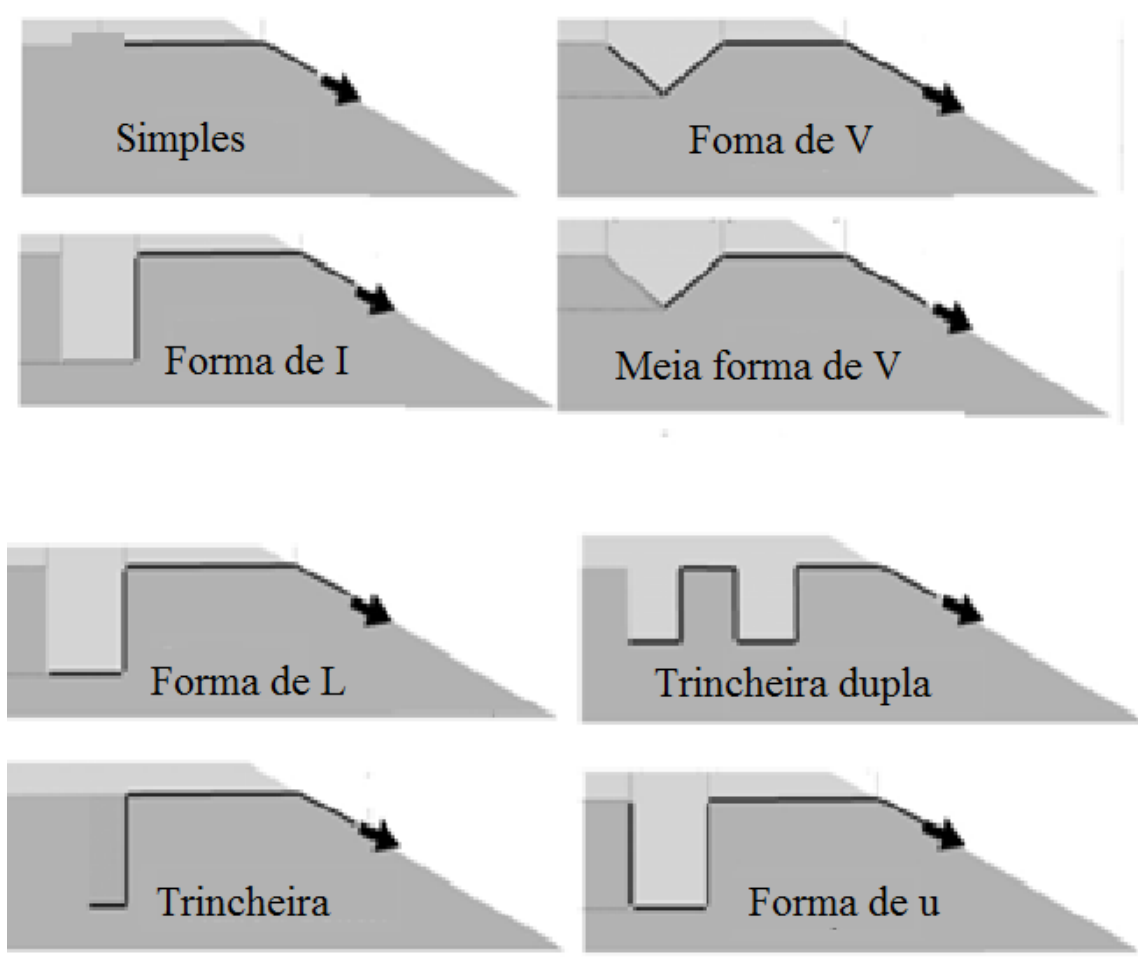

Fonte: Lajevardi; Briançon e Dias (2014)

Excetuando a ancoragem simples, todos os outros modos são classificados como modos entrelaçados. Os autores perceberam que a ancoragem simples depende dos parâmetros de rigidez do reforço e do solo, e do coeficiente de interação solo-reforço, enquanto o modo entrelaçado sempre apresenta o mesmo valor de resistência. Isso ocorre porque o modo entrelaçado tem uma mobilização 
imediata do reforço, enquanto a ancoragem simples inicia sua mobilização de forma dependente do seu deslocamento de ponta.

Quanto à inclinação, quanto mais vertical for o talude, maiores serão as deformações e mais solicitados serão os constituintes do MSRG. Esse raciocínio se aplica a todas as estruturas geotécnicas, tanto é que é um dos parâmetros de entrada para dimensionamento dos MSRG, conforme se observa nos métodos de Ehrlich e Mitchell (1994), Dantas e Ehrlich (2000) e Helwany; Reardon e Wu (1999).

Mirmoradi; Ehrlich e Dieguez (2016) estudaram o efeito da restrição horizontal inferior em modelos físicos de MSRG em diferentes inclinações de face, $75^{\circ}$ e $84^{\circ}$. Nesse trabalho é observado que há um aumento da tensão mobilizada em todas as camadas de reforço quando maior o ângulo de inclinação da face. Ao se analisar a distribuição dos deslocamentos ao longo da altura, observou-se que a maior influência da inclinação ocorreu no trecho médio da estrutura. Os autores concluíram que a restrição ao movimento horizontal do pé tem impacto mais significativo nos muros com inclinação menores, por exemplo, a liberação da movimentação do pé acarretou em um aumento de $49 \%$ na somatória da tensão máxima mobilizada para a inclinação de face de $84^{\circ} e$ de $63 \%$ para a inclinação de face de $75^{\circ}$. Por fim, pode-se concluir que a inclinação da face, como ela é construída o seu tipo influenciam no comportamento do MSRG.

\subsubsection{Efeito da altura do muro}

Para simular um MSRG com maior altura em um modelo físico aumenta-se a carga aplicada na face superior. Essa técnica tem algumas limitações, como explicado no item 2.2.2 "Protótipos de muros reforçados com geossintético".

De forma geral, quanto mais alto for o muro, mais solicitado será o reforço, até que se atinja uma altura limite que acarrete o colapso. Portanto, há uma correlação direta entre as tensões verticais em um MSRG e suas deformações internas e deslocamentos da face.

Estudos comprovaram que a altura do muro influencia mais nos deslocamentos quando a tensão vertical resultante supera a energia aplicada na compactação do solo, conforme verificado por Vasconcelos (2010). Esse estudo foi 
realizado em um modelo físico com a possibilidade de variação de intensidade e posição da carga. Observou-se também que quando o MSRG é submetido a carregamentos pontuais, ou seja, quando há a concentração de carga, é maior a mobilização dos reforços na projeção vertical do ponto de aplicação da carga. Portanto, o comportamento do MSRG está relacionado tanto à intensidade e quanto à distribuição das tensões verticais.

\subsubsection{Efeitos da água no MSRG}

O dimensionamento e análise numérica de muros reforçados muitas vezes desconsideram a ação da água, porém seus resultados devem ser utilizados com cautela, pois um dos principais motivos que levam um MSRG ao colapso é a redução nos parâmetros de resistência do maciço ou alívio das tensões efetivas no contato entre o solo e os reforços devido à ação da água.

Movimentos de fluidos na zona não saturada têm grande relevância em problemas geotécnicos. Estudos recentes têm mostrado o desenvolvimento de uma coluna de barreira capilar na interface entre solo fino e geossintético em condições não saturadas. O desenvolvimento de barreiras capilares com geossintéticos pode beneficiar determinadas aplicações na engenharia, como quando for interesse a retenção do líquido, ou prejudicar, como no caso de solos reforçados. Por outro lado, existem geotêxteis não tecidos hidrofílicos que tem um efeito oposto, o efeito da quebra capilar, podendo representar um ganho de resistência dependendo da região do muro em que se encontram (BOUAZZA et al., 2013).

O comportamento do reforço quanto à umidade também se dá de forma distinta no umedecimento ou na secagem. Lima; Palmeira e Zornberg (2014) obtiveram curvas de retenção de água em amostras de geotêxteis não tecidos com diferentes gramaturas. Foi observada uma grande diferença no comportamento durante o processo de molhagem e o processo de secagem, atribuída pelos autores ao fato de o geotêxtil analisado ser um material hidrofóbico, devido à variedade de tamanhos de distribuição de poros do material, o que dificulta a expulsão do ar durante a fase de molhagem e mantém a sucção alta no início da fase de secagem. 
Conclui-se que é importante verificar se o projeto de MSRG contempla um sistema de drenagem adequado. Deve-se ter a atenção redobrada quando houver a utilização de solos finos, pois os efeitos do fluxo de água são mais acentuados. É importante também se atentar aos efeitos da formação de barreira capilar na escolha do geossintético, para evitar a ruptura da estrutura após a construção.

Estudos sobre este tema vêm sendo desenvolvidos, entre outros, por Portelinha (2012) e Albino et al. (2016).

\subsection{MODELAGEM NUMÉRICA NA GEOTECNIA}

Para o estudo de estruturas geotécnicas complexas podem-se utilizar modelos físicos em escala reduzida ou modelos numéricos. As principais vantagens de trabalhar com modelos físicos se devem à sua fácil compreensão e à medição direta das variáveis de interesse, no entanto tais modelos têm como desvantagem demandarem grande investimento financeiro, serem de difícil duplicação e, uma vez implantados, não permitirem grandes alterações.

Modelos numéricos, por sua vez, têm como principais vantagens: a facilidade de testar diferentes configurações sem aumento substancial de tempo e custo; e poderem ser utilizados nas empresas de projetos e universidades sem investimento com infraestrutura. Em contrapartida, exigem um conhecimento prévio por parte do usuário das ferramentas de cálculo e de outras ferramentas básicas computacionais.

A modelagem numérica é a representação de uma estrutura real no ambiente virtual. Para tanto, seu comportamento é obtido a partir de equações matemáticas e da discretização espacial. Uma técnica comum na análise numérica é a utilização do método dos elementos finitos, que consiste em separar em pequenos elementos algo que é continuo no modelo físico.

O grau de discretização está relacionado com o custo computacional desse processamento, limitado à tecnologia do processador da máquina, ou seja, quanto mais precisa a análise, maior o tempo necessário para seu processamento. Discretizar, no contexto de modelos computacionais, significa a substituição de uma equação integral por um modelo numérico aproximado, com equações algébricas e incógnitas determinadas em um número finito de pontos. 
Azevedo (2003) explica matematicamente o procedimento de discretização para a aplicação do método dos elementos finitos, citando a variação de volume, onde uma equação contínua de cálculo de volume é substituída pela somatória dos valores calculados para todos os elementos.

A representação gráfica computacional dos elementos finitos é dada por uma malha de elementos triangulares ou retangulares, de acordo com o procedimento matemático para a resolução do problema. É possível também utilizar o método dos elementos finitos para analisar modelos bidimensionais ou tridimensionais.

Cada elemento dentro da malha possui parâmetros mecânicos distintos, inclusive em direções distintas. Esses parâmetros estão relacionados aos materiais da estrutura real que o modelo numérico representa. No caso de MSRG, os parâmetros dos elementos estão relacionados ao solo, ao reforço ou à face, de acordo com a posição do elemento. Portanto, para que os modelos numéricos de MSRG sejam eficientes, é necessário conhecer os parâmetros mecânicos da estrutura real e obter uma calibração consistente.

A calibração de um modelo numérico é feita comparando-se suas tensões e deformações com as obtidos de um modelo físico em condições semelhantes. Construído um modelo numérico confiável, pode-se diversos simular cenários, tornando assim a modelagem numérica uma ferramenta poderosa para realizar pesquisas. Diversos estudos estão sendo elaborados dessa forma, como alguns trabalhos abordados a seguir para ilustrar a importância dessa ferramenta.

\subsubsection{Modelagem numérica do solo}

A maior dificuldade na modelagem numérica de um muro reforçado com geossintético é a modelagem do solo. Solos são materiais naturais com grande diversidade de composição e comportamento mecânico, diferentemente dos materiais fabricados como os geossintéticos e os blocos da face do muro. Diante desse fato, os softwares numéricos apresentam diversos modelos constitutivos a serem escolhidos pelo usuário para melhor representar o comportamento do solo.

A modelagem numérica necessita da identificação dos fatores relevantes para cada tipo de análise. No caso da análise de tensões e deformações, são 
importantes parâmetros como: coeficiente de deformação, índice de variação volumétrica e tensão de plastificação. A escolha do modelo constitutivo deve contemplar o comportamento do solo em relação a esses parâmetros.

A escolha do modelo constitutivo do solo tem grande impacto no resultado de uma modelagem numérica. Bathe (1982) propôs um método para a escolha do modelo constitutivo em uma análise numérica, que consiste em simular inicialmente o comportamento do solo por um modelo numérico apontado na literatura, comparálo com dados reais, fazer ajustes e então realizar uma nova simulação, refazendo esse ciclo várias vezes até encontrar uma similaridade entre os resultados do modelo numérico e físico.

Os modelos constitutivos mais utilizados na análise numérica de solos são: modelo elástico, modelo elástico perfeitamente plástico (com critério de escoamento de Mohr-Coulomb) e modelo hiperbólico (modelo de solo com endurecimento) (PLAXIS, 2002).

Materiais com comportamento perfeitamente elástico, quando carregados e descarregados, voltam exatamente à condição inicial, enquanto outros materiais retornam parcialmente à condição inicial. No modelo elástico a relação entre tensão e deformação é descrita por uma função (linear ou não linear), sendo coincidentes suas trajetórias de carregamento e descarregamento. Quando há uma relação direta linear entre tensão e deformação, o modelo constitutivo será representado por uma equação de primeiro grau.

O modelo elástico perfeitamente plástico com critério de escoamento de Mohr-Coulomb representa um solo com comportamento perfeitamente elástico linear se não for atingida uma tensão limite. Caso esta seja atingida, o solo escoará infinitamente ou até que a tensão solicitante diminua devido ao escoamento. A tensão limite no caso dos solos é condicionada ao tradicional critério de ruptura de Mohr-Coulomb, que considera a tensão confinante, a coesão e o ângulo de atrito.

Outro modelo constitutivo que pode representar o solo é o hiperbólico, que aproxima a curva tensão-deformação a uma hipérbole. Nesse modelo o módulo de elasticidade varia com a tensão aplicada. O modelo hiperbólico se caracteriza por 
um módulo de deformabilidade não linear regido pela equação (1), onde o estado de tensões é um fator relevante. Vários autores apresentam trabalhos com $\mathrm{m}$ variando de 0,5 (siltes e areias) a 1,0 (argilas), sendo "p" a tensão confinante de referência adotada arbitrariamente (PLAXIS, 2002).

$$
E=E_{r e f} *\left[\frac{\left.c * \cos \phi+\sigma \prime_{3} * \operatorname{sen} \phi\right)}{\left.c * \cos \phi+p_{r e f} * \operatorname{sen} \phi\right)}\right]^{m}
$$

O modelo hiperbólico pode ser associado ao modelo de solo com endurecimento ou Hardening Soil Model (HSM) quando também representa o endurecimento do solo ao ser novamente submetido a uma tensão depois de sofrer descarregamento. A forma da curva tensão-deformação é similar à obtida no modelo hiperbólico, conforme mostrado na Figura 2.19 (BRINKGREVE; VERMEER, 1998).

Figura 2.19 - Hardening Soil Model (HSM)

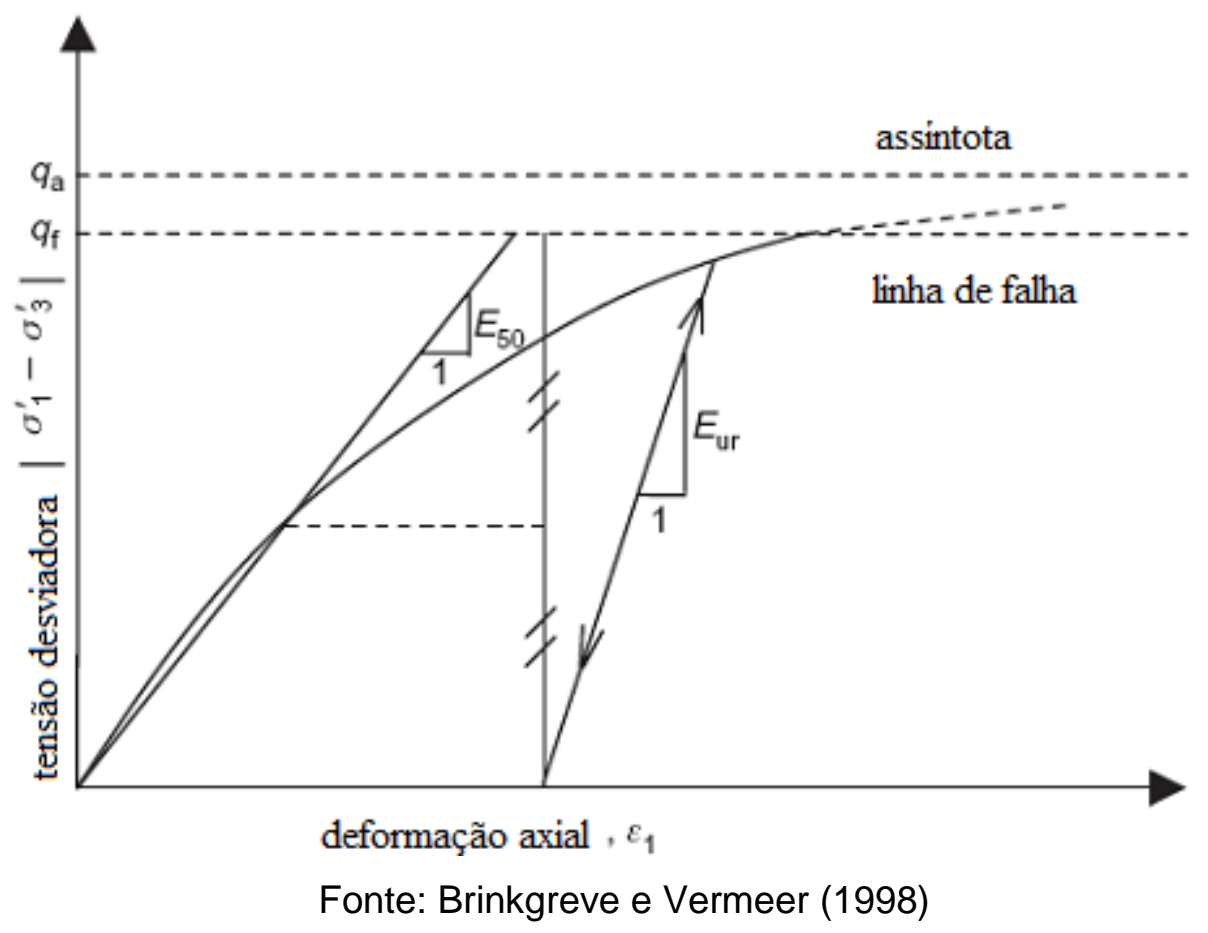

Sendo:

$E_{u r}=$ módulo de deformabilidade de descarregamento e carregamento;

$E_{50}=$ módulo de deformabilidade no carregamento; e,

m = parâmetro que controla a variação da rigidez com o estado de tensão.

Observa-se que no início do carregamento o comportamento é condicionado ao $E_{50}$, mas após ser carregado e descarregado o comportamento se dá em função 
de $E_{u r}$. Como $E_{u r}$ é maior que $E_{50}$, o solo torna-se mais rígido ao sofrer uma tensão previamente. Portanto o modelo de solo com endurecimento é mais adequado quando se quer simular efeitos como enrijecimento devido à compactação.

Diante da diversidade de modelos constitutivos disponíveis, os ensaios de laboratório podem ser utilizados como critério de escolha. Por exemplo, Teixeira (2006) e Karpurapu e Bathurst (1995) realizaram a modelagem numérica do próprio ensaio triaxial a fim de comparar as curvas tensão-deformação ao ensaio real. Realizaram-se as modelagens com o modelo constitutivo elástico perfeitamente plástico com critério de escoamento Morh-Coulomb e HSM. Com isso pôde-se também verificar se os parâmetros utilizados estavam coerentes.

Teixeira (2006) também realizou ensaios triaxiais com os reforços (geogrelhas) inseridos no corpo de prova, a fim de encontrar em qual o ângulo a geogrelha apresentava melhor eficiência. $\mathrm{O}$ autor concluiu que o modelo constitutivo do solo mais representativo foi o HSM, pois ocorria um aumento da rigidez do solo ao se aumentar a tensão solicitante. Karpurapu e Bathurst (1995) chegaram às mesmas conclusões com suas modelagens numéricas.

Por outro lado, o modelo constitutivo elástico perfeitamente plástico com critério de escoamento Morh-Coulomb teve melhor representatividade nos estudos realizados por Xue (2014). Portanto, o melhor modelo constitutivo para o solo depende da condição que se pretende simular numericamente: para a simulação em situação de ruptura, o modelo elástico perfeitamente plástico é adequado, enquanto para a condição de trabalho com solo compactado pode ser melhor representada pelo modelo HSM.

\subsubsection{Efeito da compactação na modelagem numérica}

O comportamento de um MSRG depende do grau de compactação do solo, pois a compactação aumenta a rigidez e a resistência. A simulação numérica da compactação ajuda a compreender o comportamento do muro, porém ela é difícil de ser realizada. Pesquisas recentes propõem métodos para simular a compactação em modelos numéricos, como Mirmoradi e Ehrlich (2014), mostrado na Figura 2.20. 
Figura 2.20 - Metodologia da simulação da compactação

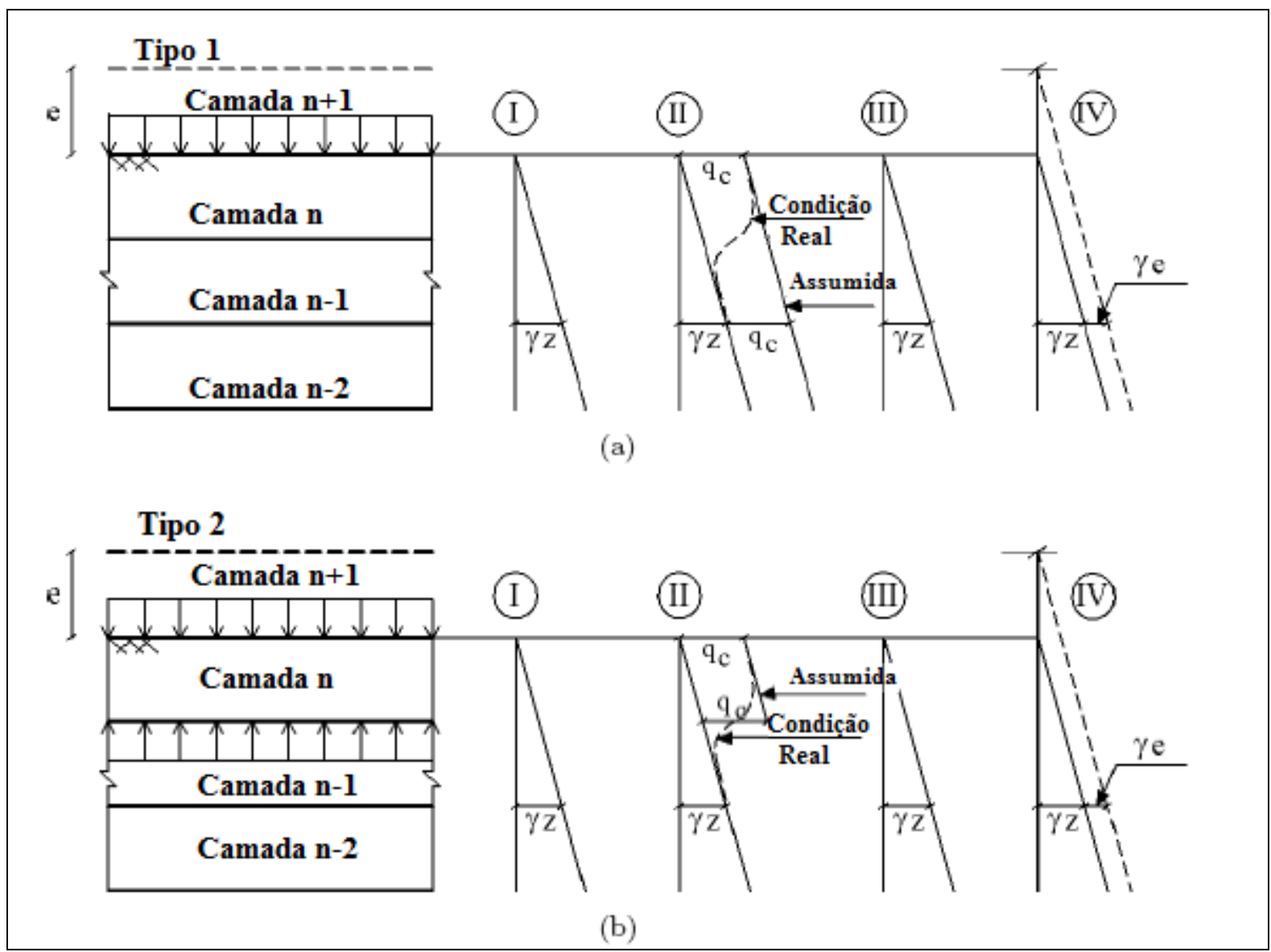

Fonte: Mirmoradi e Ehrlich (2014)

O método tipo 1 consiste em simular o efeito da compactação dinâmica pelo aumento da rigidez do solo devido a carregamentos verticais na parte superior de cada camada. No método tipo 2 há também um carregamento na parte inferior de cada camada a fim de restringir o efeito da compactação. Com isso as tensões de compactação do modelo numérico se aproximam melhor da condição real, como é observado nos diagramas (II) da Figura 2.20.a e da Figura 2.20. b. A modelagem se dá segundo as etapas da compactação da camada "n": (I) Colocação de camada de solo; (II) Equipamento de compactação em operação; (III) Final de compactação; e (IV) Colocação de camada próxima do solo (camada "n + 1").

Os autores procuraram verificar a eficiência do método comparando-o a um modelo físico. Para isso a modelagem numérica foi realizada no software Plaxis 8.0, utilizando para o solo o Hardening Soil Model, essencial para a simulação da compactação. Para o reforço foi utilizado o modelo elástico linear. A Tabela 2.4 
apresenta os valores dos parâmetros (MIRMORADI; EHRLICH, 2014), sendo possível observar a mesma relação empírica utilizada por Xue (2014), $E_{u r}=3 E_{50}$.

Tabela 2.4 - Parâmetros do modelo

\begin{tabular}{|c|c|}
\hline \multicolumn{2}{|c|}{ Parâmetros para simulação do solo - Hardening Soil Model } \\
\hline Peso específico $\left(\mathrm{kN} / \mathrm{m}^{3}\right)$ & 16,80 \\
\hline Módulo de deformabilidade secante $\mathrm{E}_{50}\left(\mathrm{kN} / \mathrm{m}^{2}\right)$ & 56.667 \\
\hline Módulo de deformabilidade último $\mathrm{E}_{\mathrm{ur}}\left(\mathrm{kN} / \mathrm{m}^{2}\right)$ & 170.000 \\
\hline Coeficiente de Poisson & 0,25 \\
\hline Coesão $\left(\mathrm{kN} / \mathrm{m}^{2}\right)$ & 1 \\
\hline Ângulo de atrito $\left(^{\circ}\right)$ & 44 \\
\hline Ângulo de dilatância $\left(^{\circ}\right)$ & 11 \\
\hline Expoente m & 0,5 \\
\hline Razão de ruptura Rf & 0,9 \\
\hline Tensão confinante de referência $\left(\mathrm{kN} / \mathrm{m}^{2}\right)$ & 80 \\
\hline Parâmetros para simulação da geogrelha \\
\hline Módulo de deformabilidade $(\mathrm{kN} / \mathrm{m})$ & 97 \\
\hline \multicolumn{2}{|c|}{ Fon } \\
\hline
\end{tabular}

Fonte: Adaptado de Mirmoradi e Ehrlich (2014)

Para a análise da compactação, diferentes fatores de energia de compactação (CF) foram considerados $(0,0,0,5,1,0$ e 2,0). O fator de energia de compactação, CF, é definido através da equação (2) (EHRLICH; MITCHELL, 1994):

$$
\mathrm{CF}=\frac{\sigma_{\mathrm{zc}, \mathrm{i}}^{\prime}}{\gamma \mathrm{H}}
$$

Onde: $\sigma_{\mathrm{zc}, \mathrm{i}}^{\prime}$ é a tensão vertical induzida durante a compactação, $\gamma$ o peso específico do solo e $\mathrm{H}$ a altura do muro.

Os autores conseguiram provar que o método é eficiente para diferentes fatores de energia de compactação, mesmo assim limita-se a simular os efeitos na rigidez do solo, não modificando os parâmetros de resistência. Portanto há a possibilidade de se simular numericamente a compactação do solo pelo método de Mirmoradi e Ehrlich (2014), com algumas restrições.

\subsubsection{Modelagem do geossintético}

A simulação numérica do reforço compreende dois aspetos: a relação tensão-deformação até se atingir a ruptura e a variação da aderência com o solo sob diferentes solicitações. A aderência do solo com o reforço é mais complicada de ser simulada, pois ela se dá por pequenos deslocamentos de interface, enquanto os 
softwares de elementos finitos (como o Plaxis 8.0) simulam deformações e não deslocamentos. Existe uma diferença entre os métodos de elementos finitos e de diferenças finitas, pois o primeiro processa as deformações internas dos elementos de malha e o segundo, os deslocamentos entre os elementos.

A fim de verificar a eficiência da simulação do reforço em diferentes modelos numéricos, Yu; Damians e Bathurst (2015) compararam com modelos físicos simulações numéricas de solos reforçados utilizando o programa FLAC (método de diferenças finitas), que oferece três opções diferentes para a modelagem do reforço (viga, cabo e elemento de faixa) e o programa Plaxis (método dos elementos finitos), com duas opções para modelagem do reforço (viga e elemento georreforço). Obtiveram-se resultados diferentes, tanto ao se comparar o software Flac com o Plaxis, quanto no mesmo programa ao utilizar elementos distintos. Especificamente para o Plaxis concluiu-se que a utilização do elemento reforço, que considera perfeita aderência entre o solo e o reforço, é eficiente, exceto quando o MSRG está próximo ao colapso ou quando deve ser avaliada a tensão cisalhante no reforço.

Outra pesquisa para verificar a eficiência da modelagem do reforço foi realizada por Tran; Meguid e Chouinad (2013). Diferente do estudo anterior, foram utilizados dois softwares em uma única simulação numérica para representar a interação solo-reforço de forma mais realista. O aterro e o reforço foram modelados pelo método dos elementos finitos, enquanto para a interação foi utilizado um software de diferenças finitas tridimensional simulando um ensaio de arrancamento. Os autores obtiveram resultados melhores quando comparados a simulações com um único software. A interação entre solo e reforço tem grande importância no comportamento tensão-deformação do MSRG nos casos em que a tensão é próxima à tensão de arrancamento, portanto nessa situação é necessária uma metodologia sofisticada de modelagem numérica.

De forma geral um MSRG dificilmente atinge a tensão de arrancamento, pois a área de contato entre o solo e o reforço é grande, diferente da Terra Armada, que utiliza fitas ao invés de mantas. Portanto, as simulações numéricas de MSRG por softwares de elementos finitos tendem a ser realistas apesar de considerarem perfeita aderência entre o solo e o reforço. 


\subsubsection{Modelagem numérica de MSRG}

Uma das preocupações da construção de um modelo numérico é o refinamento da malha. $O$ estudo da malha se mostra necessário, pois o custo computacional limita seu refinamento, por outro lado, se a malha for muito grosseira, pode-se obter um resultado muito discrepante. Um exemplo é o estudo realizado por Cecílio Jr (2009), onde uma única análise demandou 5 dias de processamento do programa Plaxis, mesmo utilizando-se uma malha grosseira para economizar tempo.

O autor apontou que resultados representativos podem ser obtidos com menor custo computacional ao refinar-se a malha apenas nos locais onde se esperam maiores variações de tensões. É aconselhado testar inicialmente algumas simulações com diferentes malhas a fim de se verificar se o refinamento da malha é justificado pela melhoria do resultado.

Em MSRG é comum o refinamento da malha próximo aos reforços e à face, conforme realizado por Riccio; Ehrlich e Dias (2014), conforme a Figura 2.21.

Figura 2.21 - Malha do modelo numérico do muro de solo reforçado

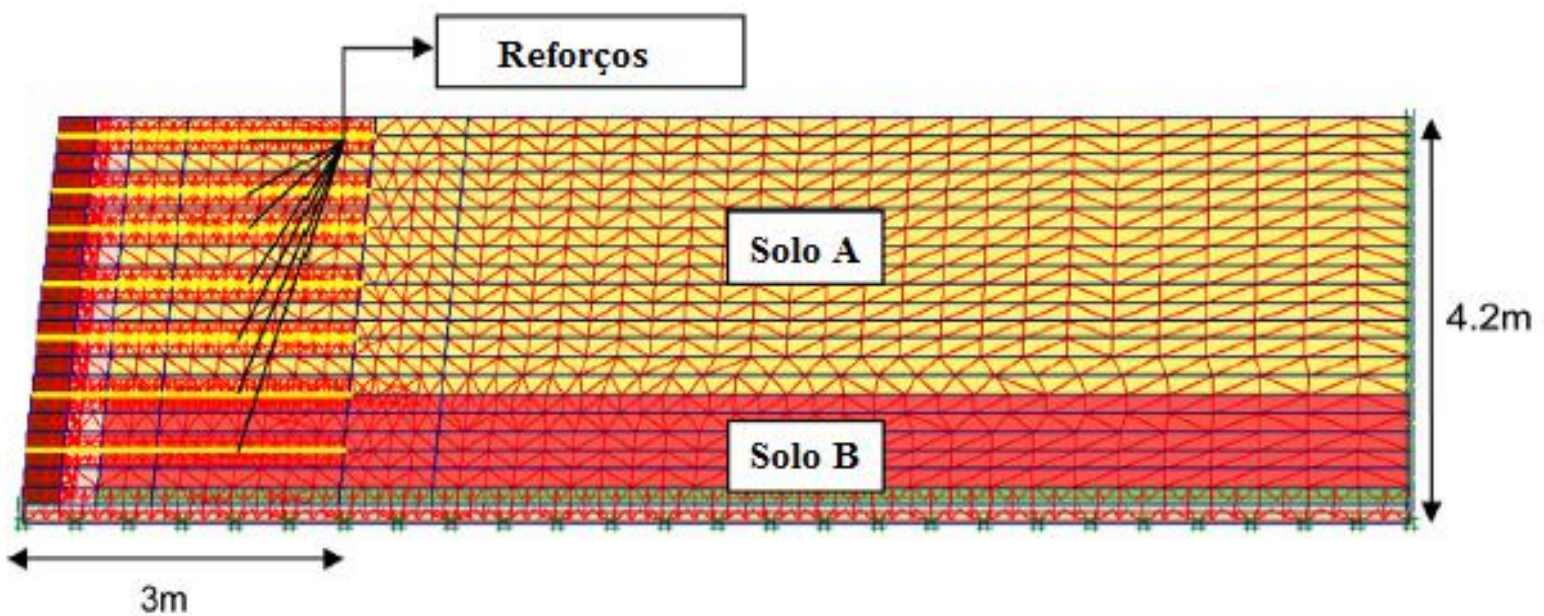

Fonte: Riccio; Ehrlich e Dias (2014)

É possível observar a distribuição dos elementos da malha, representados por triângulos, assim como as condições de contorno (restrição total na base da estrutura e restrição horizontal na face direita). Essa simulação foi validada ao ser comparada com um modelo físico, portanto a malha foi refinada satisfatoriamente e as condições de contorno foram coerentes com a realidade. 
No estudo de Riccio; Ehrlich e Dias (2014), o protótipo construído com solo fino, geogrelha de poliéster e face de concreto foi analisado numericamente pelo software Plaxis $2 D$ utilizando malha com elementos de 15 nós.

Lin et al. (2016) demonstraram que a modelagem numérica é uma ferramenta eficiente para o estudo paramétrico em MSRG. Nesse trabalho foi simulado no programa FLAC (baseado no método das diferenças finitas) estruturas que representam MSRG para medir a deformação ao se variar: os parâmetros de resistência do solo utilizado como aterro, as características de deslocamento da face, a rigidez do reforço e o carregamento superior. Com esse estudo paramétrico o autor apresenta uma estimativa de deslocamentos ao se construir estruturas semelhantes à estudada.

A análise numérica também possibilita estudar os recalques do muro devido ao adensamento do subsolo. A fim de verificar quais eram as causas do deslocamento excessivo de um MSRG e se haveria o colapso do mesmo ao longo do tempo, Xue (2014) utilizou-se da análise numérica, calibrando o modelo por meio de leituras de deslocamentos e pressões neutras. O muro foi construído com solo arenoso, representado pelo modelo constitutivo elástico perfeitamente plástico com critério de escoamento de Mohr-Coulomb. O subsolo foi modelado pelo Hardening Soil Model considerando o solo saturado. Foram utilizados os parâmetros $\mathrm{J}=620$ $\mathrm{kN} / \mathrm{m}$ e a resistência à tração de $T=70 \mathrm{kN} / \mathrm{m}$ para o reforço. Por razões de simplificação e disponibilidade dos modelos no software, adotou-se para a interface entre o solo e o geossintético um modelo rígido, com um coeficiente de interface de 0,7 , baseado em testes de arrancamento. Para o solo fino utilizaram-se as relações empíricas: $E_{u r}=3 E_{\text {oed }}=3 E_{50}$ e $\mathrm{m}=1$.

Neste caso, a fundação não foi considerada indeformável. Avaliou-se também a eficiência dos drenos e o comportamento não saturado do muro reforçado com estado estacionário de fluxo de umidade. Com o estudo numérico foi possível observar que a provável cunha de ruptura ocorreria fora do trecho de reforço, conforme Figura 2.22, não havendo o risco de ruptura por cisalhamento ou arrancamento dos reforços. 
Figura 2.22- Fator de segurança e superfície de ruptura sem os drenos funcionando

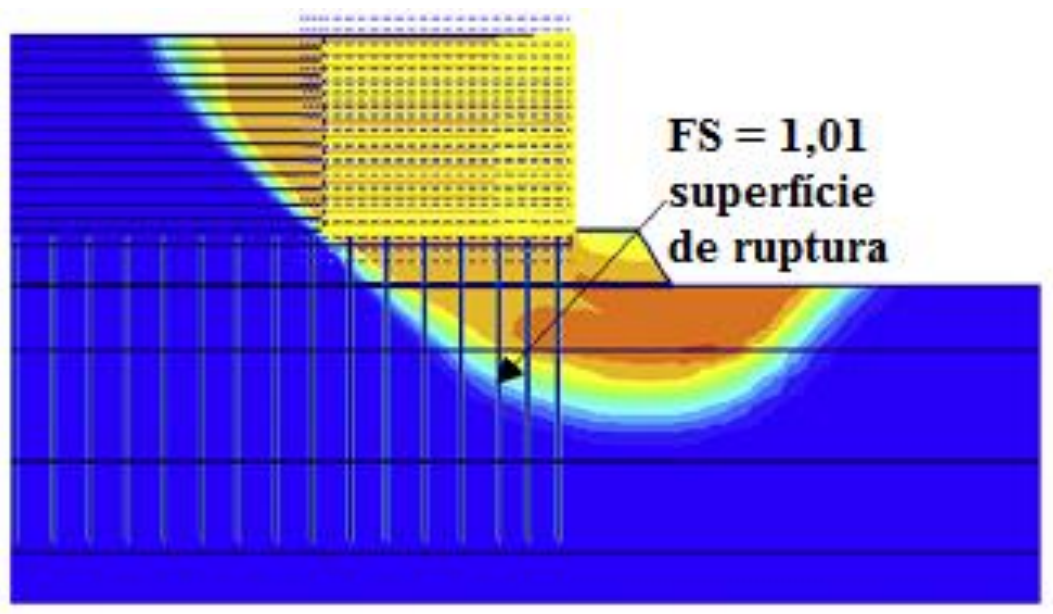

Fonte: Xue (2014)

A causa de instabilidade poderia ser a falha de funcionamento dos drenos, que acarretaria excesso de subpressão no subsolo (ROWE; SKINNER 2001). A modelagem numérica verificou que uma fundação com solos deformáveis ocasiona um aumento na solicitação dos reforços no interior do MSRG.

O estudo numérico realizado no Plaxis por Ehrlich e Mirmoradi (2013) mostrou o ganho de resistência da estrutura de muro reforçado ao ancorar o reforço na face de blocos de concreto. Notou-se também que em muitas situações a face não influi significativamente na mobilização do reforço. Através da modelagem numérica da estrutura reforçada foi possível realizar o dimensionamento da espessura do revestimento externo para cada variante, evitando-se a construção de revestimento em estruturas em que a distribuição da mobilização do reforço ficaria mais adentro do maciço.

Pesquisas numéricas de MSRG também são realizadas em modelos físicos que representam parte da estrutura, como explicado no item 2.2.2 "Protótipos de muros reforçados com geossintético". Utilizando modelagem numérica por elementos finitos DACSAR (Análise de Deformação Considerando Tensão Anisotrópica e Reorientação), Helwany; Reardon e Wu (1999) estudaram a interação entre o solo e o reforço em 144 combinações de um protótipo de MSRG (três reforços geossintéticos, dezesseis tipos de solos e três configurações de parede). Para validar o modelo numérico, foram utilizados resultados analíticos e experimentais obtidos em um ensaio laboratorial instrumentado em larga escala. A 
validação da análise numérica se deu a partir das leituras das deformações na face, cujos resultados podem ser observados na Figura 2.23.

Figura 2.23 - Deslocamentos horizontais da face

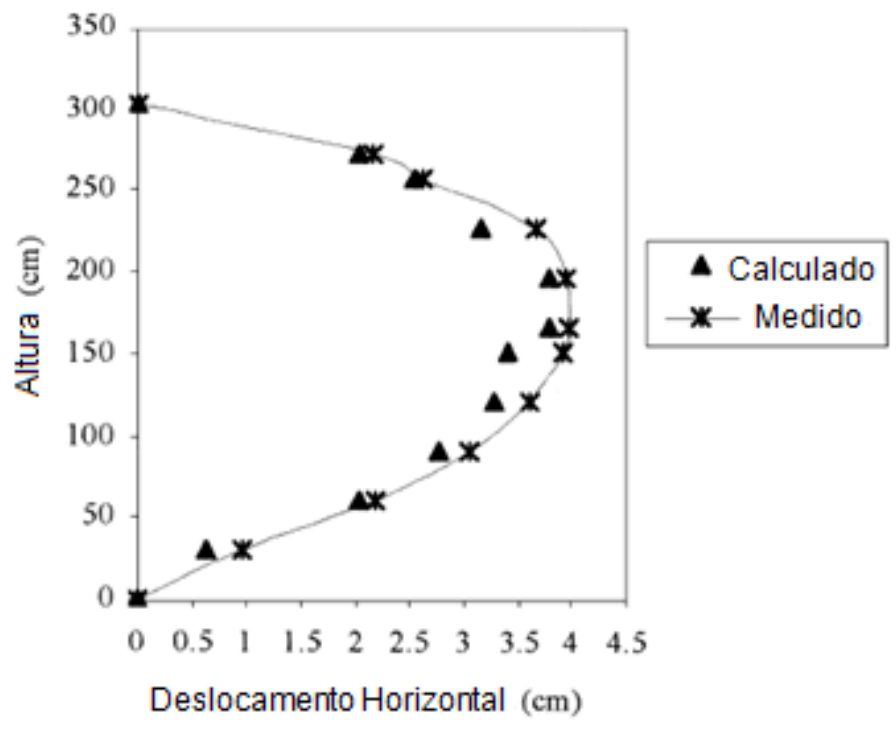

Fonte: Helwany; Reardon; Wu (1999)

Obtiveram-se deslocamentos horizontais nulos, tanto medidos no modelo físico, como calculados pelo modelo numérico, nos extremos inferiores e superiores do muro. Isso acarretou uma deformada não usual da face do muro, devido às restrições do protótipo de muro de solo reforçado.

Hatami e Bathurst (2005) utilizaram o programa FLAC para investigar o efeito da compactação e o efeito do aumento da carga, assim como para comprovar o modelo constitutivo adotado para os materiais (blocos, solo, reforço). O estudo apresentou resultados previstos na literatura, como o aumento da deformação com a diminuição dos parâmetros de resistência dos materiais. Houve sensíveis diferenças entre o modelo numérico e o modelo físico de referência, conforme a Figura 2.24. 
Figura 2.24 - Deslocamentos horizontais da face
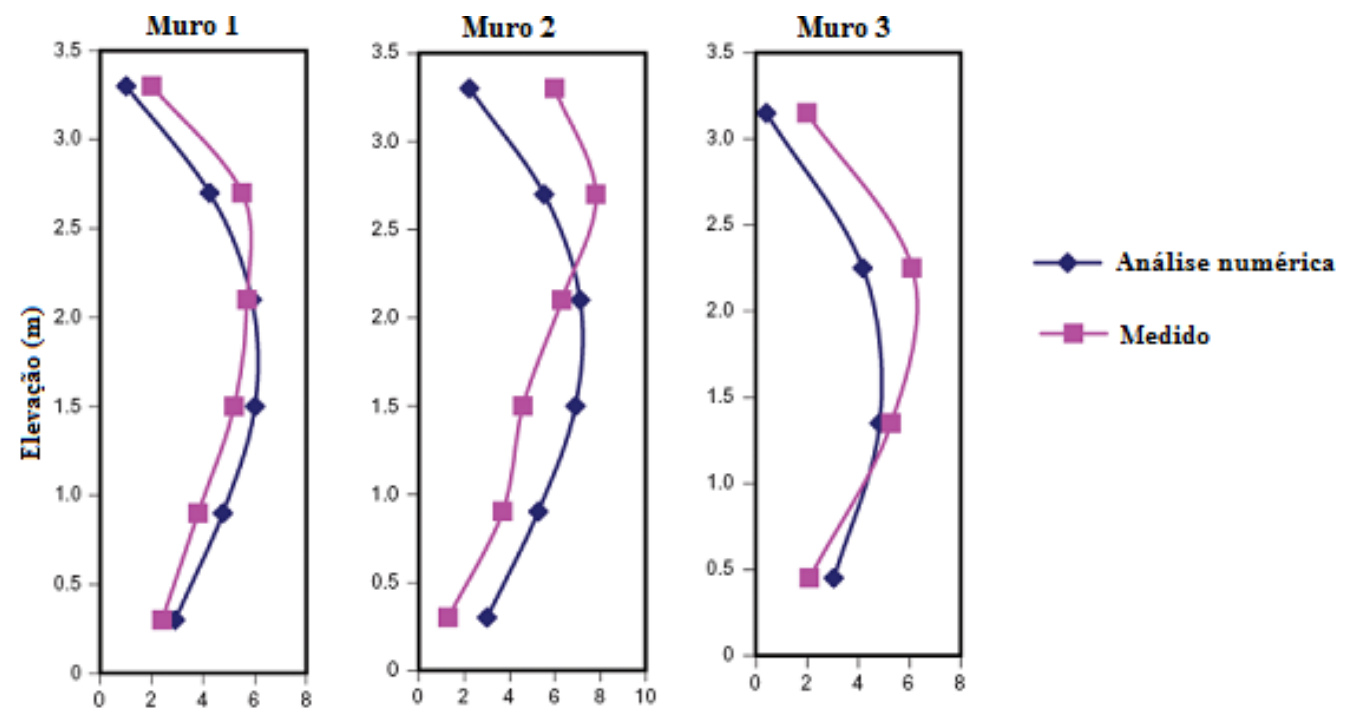

Deslocamento relativo da face $(\mathrm{mm})$

Fonte: Hatami; Bathurst (2005)

Os autores justificam tais diferenças devido aos blocos não se moverem de maneira uniforme em cada elevação. Assim como no modelo numérico de Helwany; Reardon e Wu (1999), foi possível observar que os maiores deslocamentos ocorreram no trecho médio das estruturas, devido às condições dos vínculos nas extremidades do protótipo.

Os estudos de modelos numéricos apresentados neste capítulo foram realizados com um estado estacionário de umidade. Os estudos de Park (2005); de Iryo e Rowe (2005) e de Yoo e Jung (2006) demonstram a grande importância do fluxo de umidade em meio não saturado, pois a redução dos parâmetros de resistência pode levar ao colapso da estrutura. A condição estacionária de umidade é uma hipótese muito restrita das condições a que a estrutura real estará sujeita e deve ser utilizada com cautela no dimensionamento do muro, sendo importante a verificação das variações de umidade que a estrutura irá sofrer ao longo da vida útil.

Conclui-se que é possível modelar numericamente um MSRG com eficiência. Porém deve ser verificado se: a malha é adequada; as condições de contorno são validas; não há influência da fundação, e se pode ser adotado o estado estacionário de umidade. Salvo essas verificações, a utilização de modelagens numéricas em MSRG é uma ferramenta poderosa para pesquisas futuras. Ressalta-se que a 
modelagem numérica, quando comparada a ensaios laboratoriais, apresenta como vantagem um menor custo e menor tempo para sua execução, além de possibilitar a simulação de estruturas de grande porte. 


\section{MODELAGEM NUMÉRICA BASEADA EM MODELO FÍSICO}

O objetivo principal desta pesquisa é realizar a modelagem numérica de um muro de solo reforçado com geossintético utilizando-se o software de elementos finitos. Dada a dificuldade de se construir diretamente um modelo numérico de um solo de muro reforçado com geossintético diante do grande número de variáveis e de modelos constitutivos disponíveis, adotou-se como metodologia da pesquisa um aumento progressivo de complexidade das análises, iniciando-se com a modelagem numérica de um modelo físico.

\subsection{MODELO FÍSICO DE PORTELINHA (2012)}

Inicialmente foi realizada a modelagem numérica do modelo físico de MSRG desenvolvido por Portelinha (2012) no Laboratório de Geossintéticos da Escola de Engenharia de São Carlos da Universidade de São Paulo. Esse modelo físico foi escolhido devido a: utilização de um solo tropical; construção de forma a atender a condição de estado plano de deformação, definida para a análise numérica; aplicação de carga de forma controlada; e disponibilidade de leituras de tensões, deformações, sucção e umidade.

O modelo físico desenvolvido por Portelinha (2012) foi construído em uma caixa metálica com dimensões internas 1,80 m de altura x 1,55 m de largura x 1,80 $\mathrm{m}$ de comprimento, com paredes de aço reforçadas para suportar elevadas tensões laterais de solo e apresentar deformações laterais resultantes praticamente nulas, garantindo assim o estado plano de deformações. Os materiais utilizados foram um solo tropical e um geossintético de menor custo e rigidez (geotêxtil não tecido). $\mathrm{O}$ solo foi compactado e envelopado pelo geotêxtil com o uso de formas móveis. Sobre a estrutura foi aplicada uma tensão vertical constante de $100 \mathrm{kPa}$ por meio de uma bolsa inflável de ar, que transferia a carga por uma tampa de reação parafusada no topo de cada parede lateral.

O solo utilizado no modelo físico é um solo laterítico típico do interior do Estado de São Paulo, coletado no Campus II da Universidade de São Paulo, cidade de São Carlos - SP. Sua origem geológica é sedimentar cenozoica, produto do retrabalhamento dos materiais do Grupo Bauru e das Formações Serra Geral e 
Botucatu, através de transporte em meio aquoso, e depositado em formas de aluviões e coluviões, posteriormente laterizados (Portelinha, 2012). Em termos geotécnicos, trata-se de uma areia argilosa (SC) com $40 \%$ de finos (IP=20\% e $\mathrm{LL}=20 \%$ ), que apresenta parâmetros de compactação $\mathrm{Ydmax}_{\mathrm{d}}=17,9 \mathrm{kN} / \mathrm{m}^{3}$ e wopt= 14,6\% na energia Proctor Normal. Com o grau de compactação de 98\%, este

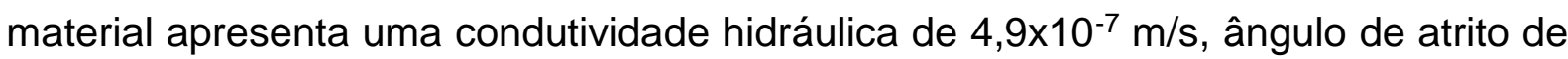
$27^{\circ}$ e coesão de $32 \mathrm{kPa}$ (ensaios triaxiais do tipo CD com solo na umidade de compactação).

O autor escolheu geotêxteis não tecidos porque podem cumprir a dupla função de reforço e drenagem interna, além de que apresentam boa resistência de interface com solos finos. Geotêxteis não tecidos agulhados de poliéster com gramatura de $300 \mathrm{~g} / \mathrm{m}^{2}$ foram utilizados como reforços. As propriedades de ensaios de tração faixa-larga são: resistência de $11 \mathrm{kN} / \mathrm{m}$ e deformação máxima de $87 \%$.

Para simular a ficha do MSRG, uma barra de aço transversal de $0,15 \mathrm{~m}$ de espessura foi colocada na base do modelo travando os $0,15 \mathrm{~m}$ inferiores da face aberta (frente do muro) para evitar deslocamento horizontal. Assim, apesar do modelo ter 1,65 m de altura, considerou-se a altura do muro como 1,50 m.

A execução, programa de instrumentação e monitoramento do modelo físico estão detalhados em Portelinha (2012). A Figura 3.1 mostra uma seção transversal do modelo físico experimental, denominado M1 pelo autor, uma vez que em seu trabalho foram estudadas 4 configurações (M1 a M4). 
Figura 3.1 - Seção transversal do modelo físico de MSRG de Portelinha (2012)

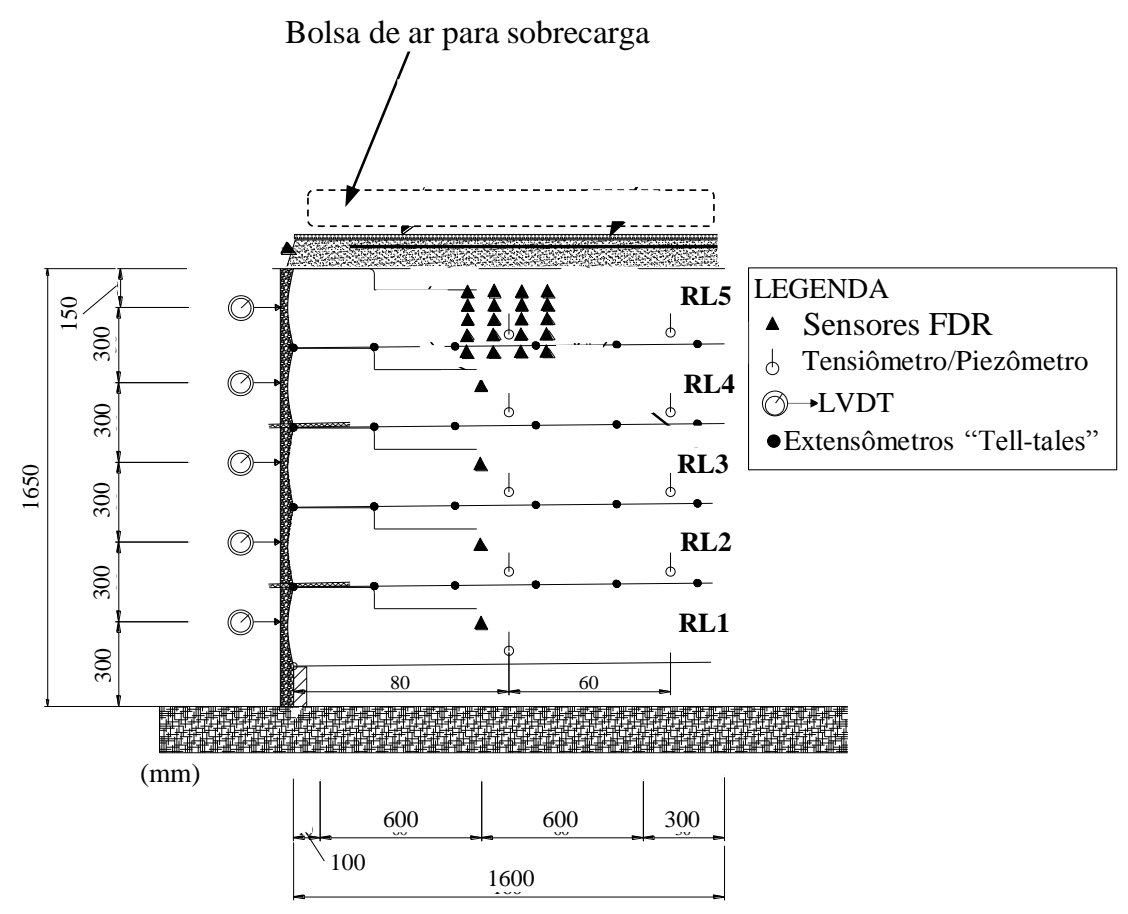

Fonte: Portelinha (2012)

A distribuição da instrumentação teve como objetivo abranger a maior área possível, propiciando a compreensão de como são as tensões no interior do modelo físico e, por consequência, a solicitação do reforço. A tensão no interior é resultado tanto das características do solo e do reforço quanto das condições de contorno. No topo a tensão aplicada pela bolsa é de $100 \mathrm{kPa}$. Na base inferior a tensão tem intensidade devida à soma da carga aplicada pela bolsa com o peso do solo. A solicitação das paredes laterais decorre do surgimento de tensões horizontais no solo. Na mecânica dos solos clássica a tensão horizontal no solo sem deformação horizontal pode ser estimada pelo coeficiente de empuxo em repouso de Rankine, que se dá em função do ângulo de atrito e da coesão do solo. A Figura 3.2 mostra uma seção transversal com a contribuição das condições de contorno do modelo físico, cuja tensão horizontal foi calculada pelo método de Rankine. 
Figura 3.2 - Condições do entorno do modelo físico.

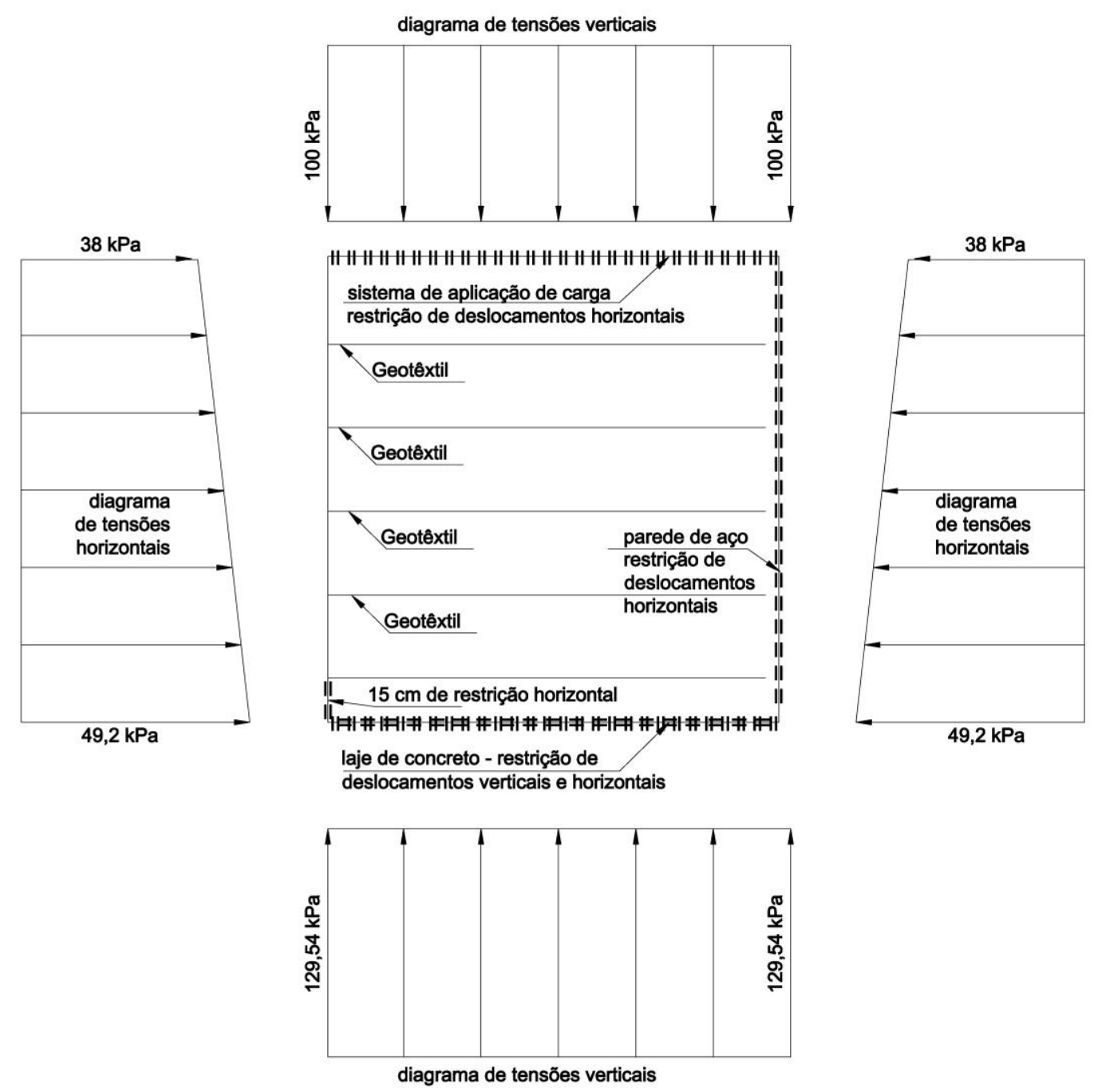

Fonte: Próprio autor

A figura é uma forma didática de entender o que ocorre no modelo físico, porém é esperado que as tensões horizontais tenham intensidades diferentes, uma vez que a face exposta não possui restrições de deslocamentos. As tensões horizontais acarretam em deformações horizontais, por consequência o geotêxtil (reforço) é mobilizado. Dessa forma o modelo físico pode ser utilizado para estudar o comportamento dos MSRG. 


\subsection{MODELO NUMÉRICO BASEADO NO MODELO FíSICO DE PORTELINHA (2012)}

\subsubsection{Software Plaxis}

Para a modelagem numérica do modelo físico e as simulações de MSRG foi utilizado o software Plaxis 2D, baseado no método dos elementos finitos. A principal ferramenta do software é a analise de deformações de estruturas geotécnicas, possibilitando a escolha entre diversos modelos constitutivos para o solo, além de já possuir a geogrelha como uma das opções de entrada de materiais.

Para utilizar um modelo bidimensional, deve-se verificar se a estrutura trabalha no estado plano de deformação, como é o caso do modelo físico de Portelinha (2012) e de uma seção transversal de um muro longo. O software disponibiliza também a alternativa de simular em 2D uma estrutura axissimétrica, geralmente empregada na simulação de ensaios de compressão triaxial.

A discretização é feita por elementos triangulares, com 6 ou 15 nós por elemento. $\mathrm{Na}$ análise de tensões, estes se convertem em 3 ou 12 nós por elemento, respectivamente. Neste trabalho, foram utilizados elementos de 15 nós, segundo recomendação do manual.

\subsubsection{Construção do modelo numérico}

A primeira simulação computacional foi realizada para o modelo físico M1 construído por Portelinha (2012) na situação de carga de $100 \mathrm{KPa}$ aplicada pelo compressor durante 90 dias com teor de umidade constante. A carga aplicada corresponde a aproximadamente $5 \mathrm{~m}$ de altura de muro. A Figura 3.3 mostra o modelo numérico do protótipo construído no software Plaxis. 
Figura 3.3 - Modelo construído no software Plaxis

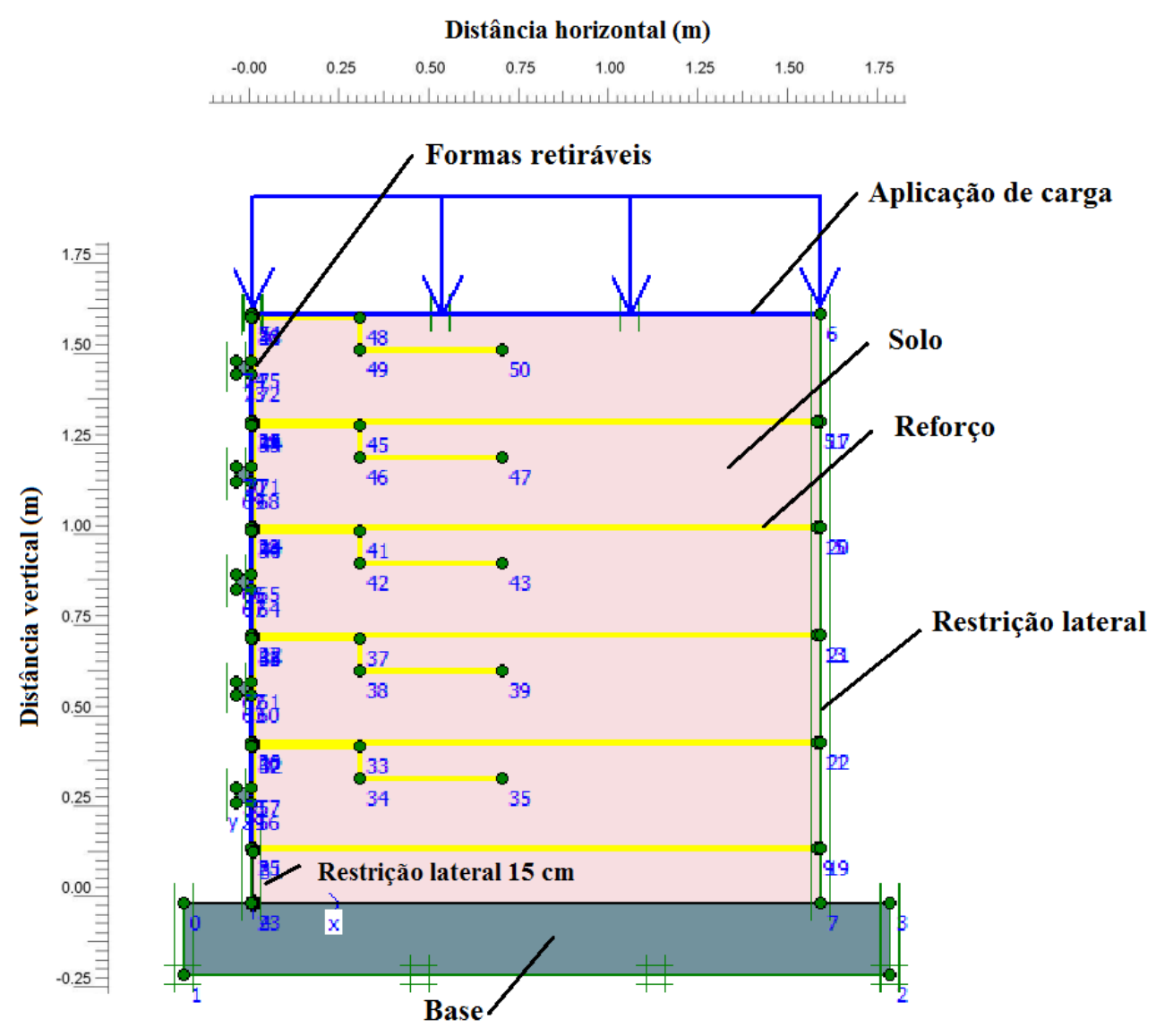

Fonte: Próprio autor

As condições de contorno adotadas foram:

- A face do fundo do modelo físico foi representada por uma condição de contorno que não permite deslocamento horizontal nem rotação, só deslocamento vertical (2 vínculos);

- Como a face exposta do modelo físico é livre para se deslocar, a condição de contorno é sem vínculos, podendo se deslocar e girar;

- A base foi simulada com 3 vínculos (sem deslocamentos e rotação), com elementos de rigidez alta o suficiente para não acarretar deslocamentos adicionais no MSRG, simulando a laje de reação sobre a qual foi construído o modelo físico;

- A face superior (topo) do muro foi simulada sem deslocamento horizontal (um vínculo), devido à presença do sistema de aplicação de carga vertical. 
Realizou-se um estudo prévio do refinamento da malha. Percebeu-se que o refinamento máximo do software não ocasionava diferenças significativas nos resultados nem custo computacional significativo (tempo de processamento). Adotou-se, portanto, a malha mais densa possível em cada simulação. Na Figura 3.4 é mostrado o modelo numérico com a malha de processamento com 1.484 elementos e 12.129 nós.

Figura 3.4 - Malha de elementos finitos do modelo numérico

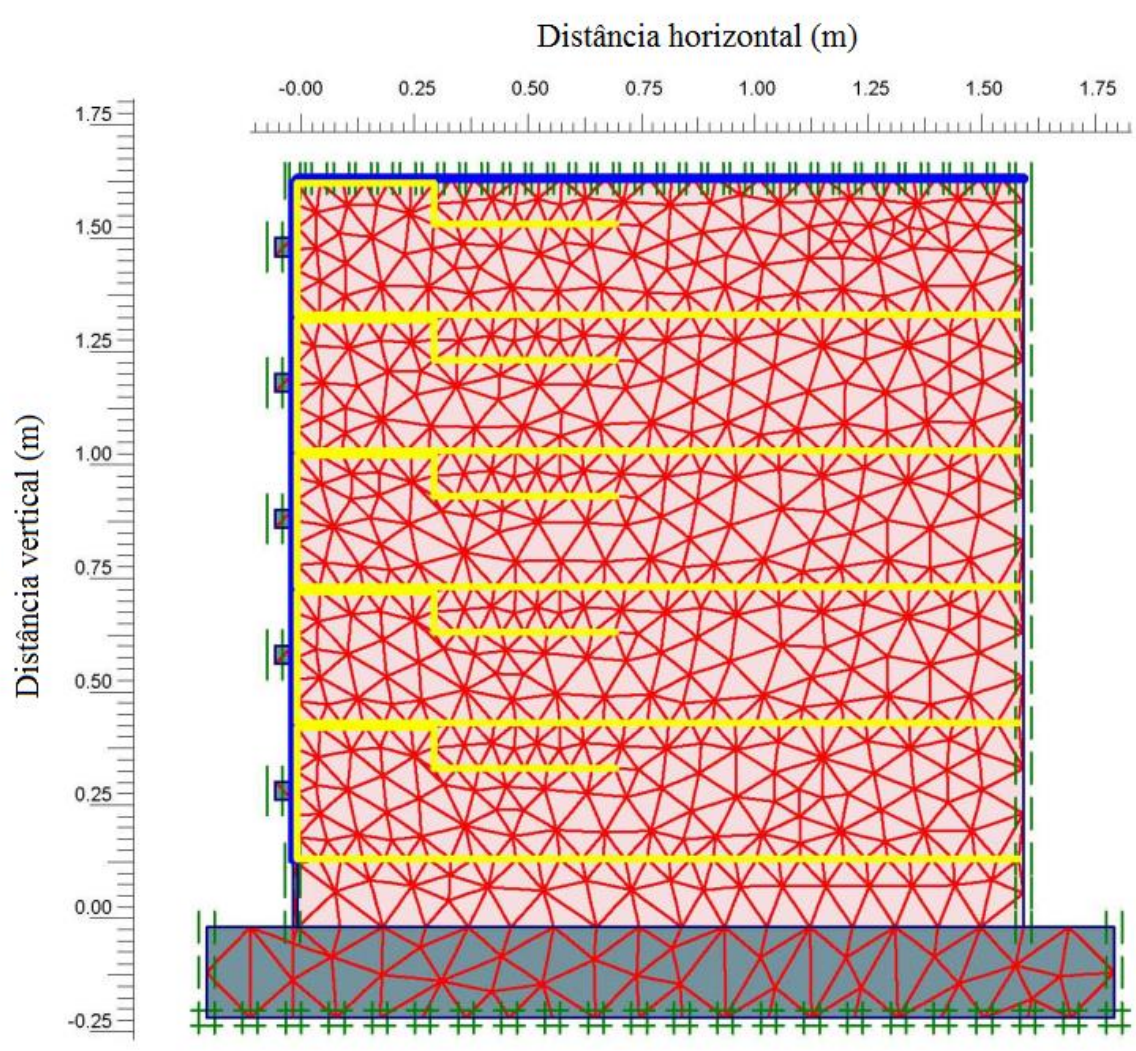

Fonte: Próprio autor

\subsubsection{Parâmetros de entrada do modelo constitutivo}

Quanto mais complexo o modelo de comportamento tensão-deformação de uma simulação numérica, maior a quantidade de parâmetros necessários para a calibração do modelo. Para início das análises adotou-se para o comportamento do solo o modelo elasto-plástico com critério de escoamento em Morh-Coulomb. Para modelagem do solo segundo este modelo constitutivo são necessários os seguintes parâmetros: (1) peso do solo na umidade natural, (2) peso do solo submerso, (3) módulo de deformabilidade do solo, (4) coeficiente de Poisson, (5) coesão, (6) 
ângulo de atrito e (7) ângulo de dilatância. Os valores utilizados foram, respectivamente, $17,9 \mathrm{kN} / \mathrm{m}^{3}, 17,9 \mathrm{kN} / \mathrm{m}^{3}$ (este parâmetro não foi utilizado porque não se supôs mudança de umidade), $17.000 \mathrm{kN} / \mathrm{m}^{2}, 0,3,32 \mathrm{kPa}, 27^{\circ}$ e $0^{\circ}$.

A seguir utilizou-se o modelo constitutivo de soil hardening. Foi adotado como simplificação um coeficiente de interface rígido entre o solo e o reforço. É esperado que o comportamento da interface entre o solo e o reforço no modelo numérico se aproxime do ocorrido no modelo físico, conforme observado por Yu; Damians; Bathrust (2015). Para o solo foram adotadas as seguintes relações empíricas: $E_{u r}=3 E_{\text {oed }}=3 E_{50}$ e $\mathrm{m}=1$ apontadas por Xue (2014).

Para a simulação do comportamento do reforço, foi utilizado o modelo elástico linear, para o qual é necessário o modulo de deformabilidade. Esse parâmetro foi obtido a partir de ensaios realizados por Portelinha (2012). Adotou-se como ruptura deformações superiores a $3 \%$, que correspondem ao arrancamento do geotêxtil em relação ao solo que o envolve (Portelinha, 2012).

\subsection{CALIBRAÇÃO DO MODELO NUMÉRICO}

Para calibrar o modelo numérico, compararam-se os deslocamentos horizontais da face do muro calculados pelo modelo numérico e os medidos no modelo físico 90 dias após a construção, quando houve a estabilização dos deslocamentos, conforme mostra a Figura 3.5

Inicialmente foi feita a simulação do modelo numérico totalmente construído e carregado, com o comportamento do solo representado pelo modelo elasto-plástico com critério de escoamento em Mohr-Coulomb. 
Figura 3.5- Comparação entre os deslocamentos horizontais medidos no modelo físico de Portelinha (2012) e calculados no modelo numérico

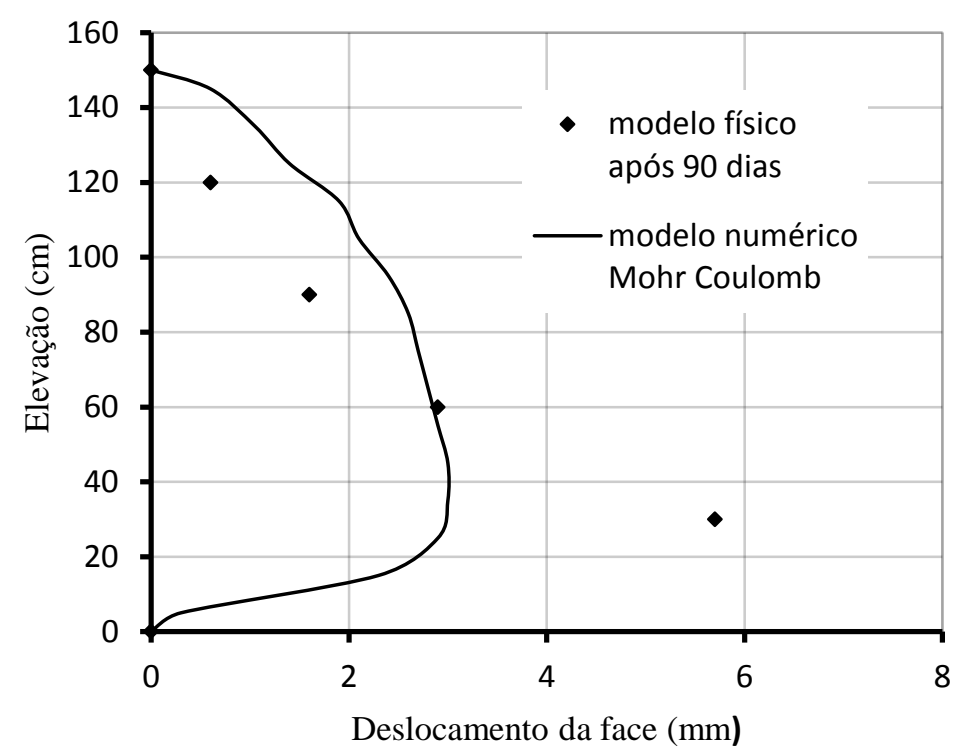

Fonte: Próprio autor

Embora os deslocamentos medidos e calculados da face tenham apresentado a mesma ordem de grandeza, o perfil de deslocamentos do modelo numérico foi muito diferente do medido no modelo físico.

Os valores medidos apresentaram-se diferentes dos resultados obtidos nos trabalhos de Helwany; Reardone e Wu (1999) e Hatami e Bathurst (2005) em modelos físicos semelhantes, apresentados respectivamente na Figura 2.23 e na Figura 2.24: no primeiro trabalho o deslocamento máximo medido ocorreu próximo ao ponto médio do muro, enquanto no segundo os máximos deslocamentos medidos em três experimentos ocorreram entre o ponto médio e o quarto superior do muro.

Também quanto à modelagem numérica, os valores obtidos nesta pesquisa diferiram em relação a esses dois trabalhos, nos quais o máximo deslocamento ocorreu no ponto médio do muro.

Pela teoria de Rankine, as tensões horizontais estão relacionadas ao coeficiente de empuxo do solo (em repouso ou ativo) e à tensão vertical, resultando em um diagrama triangular, com resultante no terço inferior do muro. Por outro lado, o efeito de arqueamento em muros não reforçados tende a elevar o ponto de aplicação da resultante para cima. Nos muros reforçados, quando o solo se desloca, os reforços 
são solicitados e contribuem para absorver parte das tensões horizontais, alterando sua distribuição.

No modelo físico estudado, a face superior não pode se deslocar devido à laje, que transfere uma sobrecarga vertical de $100 \mathrm{kPa}$ aplicada por meio de uma bolsa de ar inflável. Considerando-se uma altura de 1,65 $\mathrm{m}$ de solo compactado no ponto ótimo da energia de Proctor normal $\left(\gamma \mathrm{dmax}=17,9 \mathrm{kN} / \mathrm{m}^{3}\right.$ e wopt $=14,6 \%$, ou seja, $\gamma=$ $20,5 \mathrm{kN} / \mathrm{m}^{3}$ ), obtém-se o valor de $33,85 \mathrm{kPa}$. Na parte inferior há uma reação para manter o equilíbrio estático de 133,85 kPa, que é igual à sobrecarga de $100 \mathrm{kPa}$ acrescida das tensões verticais devidas ao peso próprio do solo.

Analisando a Figura 3.2, a diferença de tensões horizontais entre a base e 0 topo (34\%) não justificaria um aumento tão significativo de deslocamentos nas cotas mais baixas, uma vez que na base e no topo há restrições de deslocamentos horizontais.

Hatami; Bathurst (2005) sugerem que as diferenças nos deslocamentos entre as modelagens físicas e numéricas podem ocorrer por algumas imprecisões na montagem do modelo físico, como na compactação do solo. Considerando-se essa hipótese, procurou-se simular o efeito de compactação, que tem grande importância no comportamento de um MSRG (EHRLICH; MIRMORADI; SARAMAGO, 2012). A simulação da compactação na modelagem numérica foi realizada segundo o método 1 proposto por Mirmoradi e Ehrlich (2014). Ressalta-se que na simulação da compactação foi utilizado o Hardening Soil Model, modelo constitutivo mais adequado para a simulação da compactação em uma modelagem numérica (MIRMORADI; EHRLICH, 2014).

A execução do modelo numérico se deu então da mesma forma que a construção do modelo físico, ou seja, procurou-se modelar a sequência de compactação das camadas de solo. Como a construção do modelo físico se deu em etapas, com a fixação de forma móvel, escoramento da forma, lançamento do solo, compactação da camada de solo, instalação do geotêxtil e deslocamento da forma para a execução da próxima camada, a modelagem também foi realizada em etapas de $30 \mathrm{~cm}$ (sete ao todo). 
A camada inicial de $0,15 \mathrm{~m}$ foi modelada com restrição de deslocamento na face, devido à colocação da barra de aço fixa no pé do modelo físico para representar a ficha. A seguir, o processo de compactação foi simulado com base no método 1 sugerido por Mirmoradi e Ehrlich (2014), segundo o qual a energia de compactação dinâmica é convertida em uma tensão vertical uniforme distribuída sobre a superfície da camada até os deslocamentos do solo se estabilizarem.

Modelou-se uma camada de 0,30 m com aplicação de uma tensão vertical; a tensão era desconsiderada na camada já compactada e novamente aplicada na camada superior conforme esquema apresentado na Figura 3.6. Este procedimento foi repetido ao longo de toda a altura do modelo. $O$ valor adotado para a carga vertical aplicada a cada camada de solo compactado foi $98,2 \mathrm{kPa}$, com base em Mirmoradi e Ehrlich (2014) e no melhor ajuste visual obtido para uma faixa de valores testados. Esse método possui algumas limitações, pois não simula o acréscimo de resistência do solo pela compactação, apenas simula o acréscimo do módulo de elasticidade do solo.

Para simular as formas móveis, fixadas durante a compactação de cada camada de solo e retiradas para o lançamento da camada seguinte, no modelo matemático também se impôs deslocamento horizontal nulo durante a construção de cada camada de solo. As formas foram, portanto, simuladas por elementos Plate com restrição de deslocamento lateral, sendo colocadas e retiradas camada por camada.

Figura 3.6 - Construção do protótipo em etapas no software Plaxis

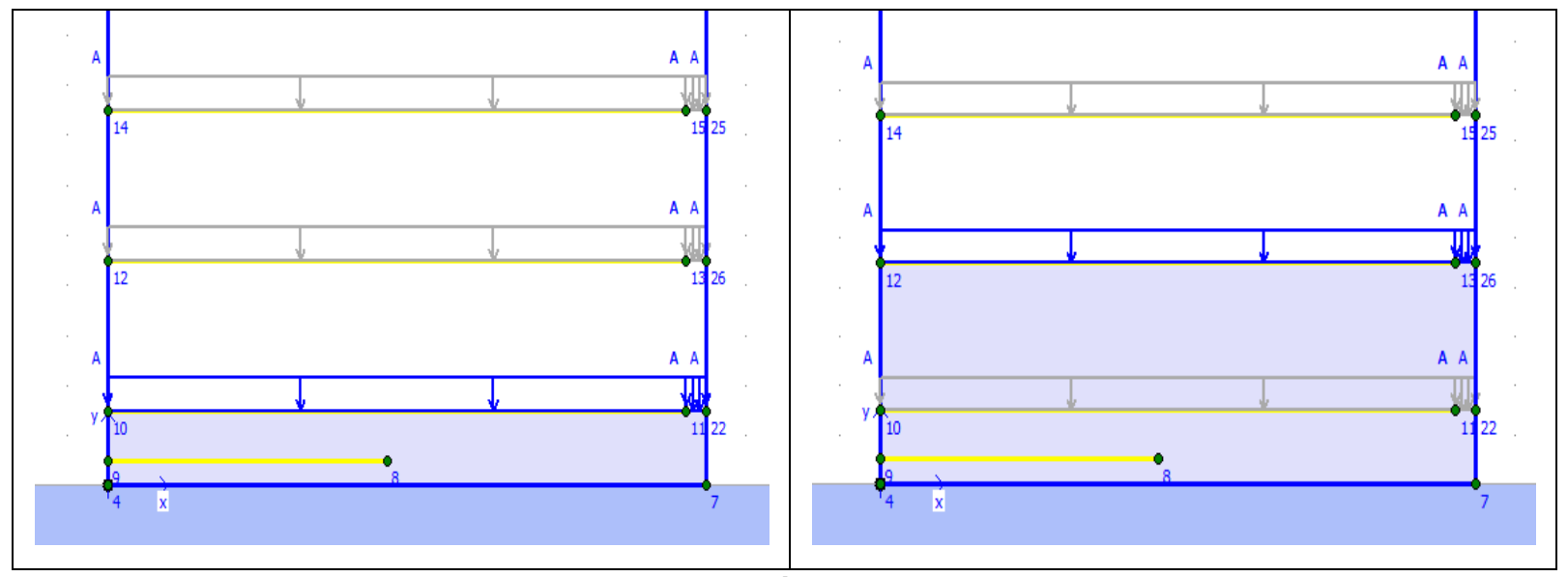

Fonte: Próprio autor 
Quando o modelo numérico havia atingido a altura final do modelo físico, ou seja, ao término da última camada de solo compactado e retirada do escoramento no final da construção, os deslocamentos foram zerados, para considerar apenas a influência de tensões aplicadas sobre o muro construído. Aplicou-se então a tensão vertical de $100 \mathrm{kPa}$ no topo da estrutura, simulando a tensão aplicada pela bolsa de ar comprimido.

Os resultados da calibração do modelo físico de Portelinha (2012) com e sem consideração da compactação encontram-se na Figura 3.7.

Figura 3.7- Comparação entre os deslocamentos horizontais calculados no modelo numérico sem e com simulação da compactação

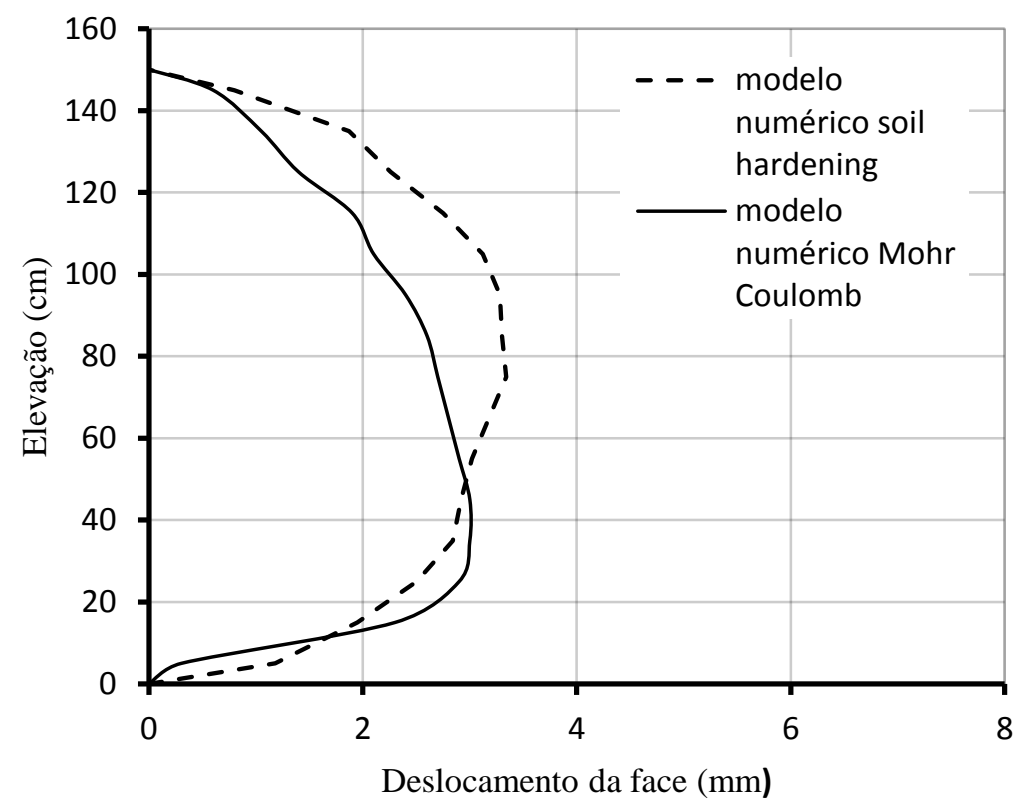

Fonte: Próprio autor

Observa-se que a simulação da compactação (ou seja, construção em etapas, aplicação de carga estática a cada camada, endurecimento do solo e anulação dos deslocamentos construtivos) resultou em uma alteração da curva de deslocamentos horizontais na face em função da altura, tornando-a mais próxima dos resultados de Helwany; Reardone Wu (1999) e Hatami e Bathurst (2005), porém mais distantes dos resultados obtidos no modelo físico.

Procurou-se encontrar possibilidades de imprecisões durante a construção do modelo físico. A seguir repetiu-se todo este processo com uma variação: na 
compactação da primeira camada, deixou-se a forma deslocar 0,005 m. Tentou-se assim representar a heterogeneidade da compactação, com a parte inferior do muro sujeita a maiores deslocamentos. Barbosa Júnior (2003) observou que deslocamentos da forma durante a compactação (da ordem de 0,005 m) são responsáveis por diferentes comportamentos do MRSG após término da construção, neste caso os deslocamentos da face no modelo numérico se aproximariam melhor dos deslocamentos da face medidos no modelo físico.

Uma pequena diferença na compactação do solo da primeira camada durante a montagem do modelo físico acarretaria uma parcela ligeiramente menos rígida no trecho inferior. Consequentemente, ao ser aplicado o carregamento de $100 \mathrm{kPa}$ na face superior do modelo construído, ocorreriam maiores deslocamentos no trecho inferior.

Esta hipótese permitiu obter um perfil de deslocamentos da face do modelo numérico mais próximo do modelo físico, conforme exposto na Figura 3.8.

Figura 3.8 - Comparação entre os deslocamentos horizontais medidos no modelo físico de Portelinha (2012) e calculados no modelo numérico com simulação de compactação e deslocamento de $0,005 \mathrm{~m}$ na primeira camada

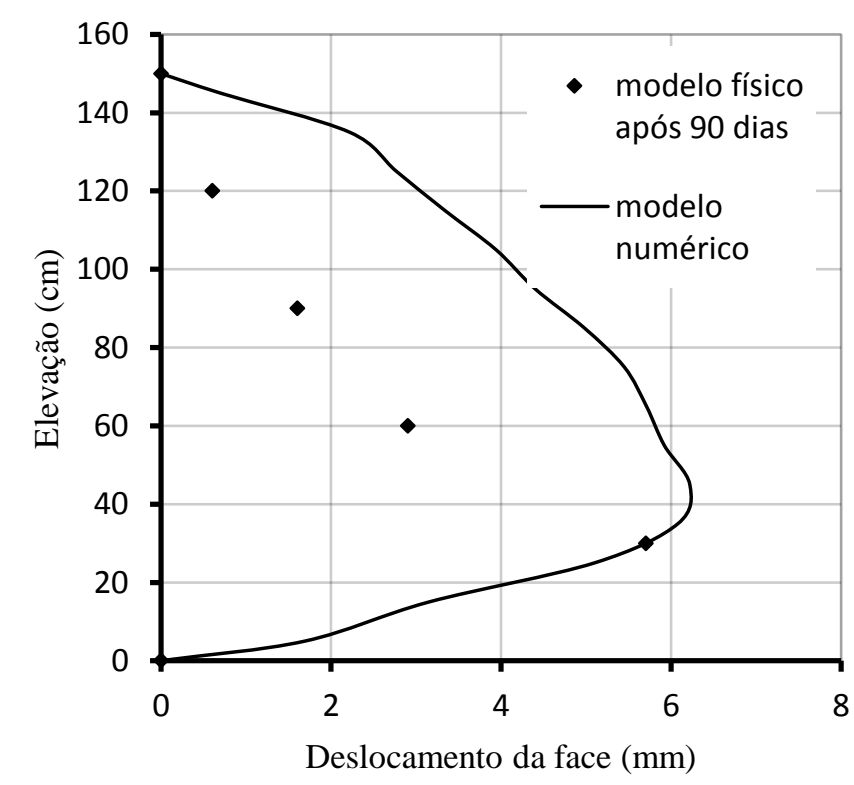

Fonte: Próprio autor

A Figura 3.9 mostra a comparação entre as deformações horizontais em função da distância até a face externa no reforço mais solicitado nos modelos físico e 
numérico. Observa-se boa concordância entre as curvas: no modelo físico foi medida a deformação máxima de 3,6 \% a 300 m de distância da face, enquanto o numérico aponta deformação máxima de 3,2 \% a 200 mm da face.

Figura 3.9 - Deformação horizontal no geossintético no trecho mais solicitado em função da distância até a face externa

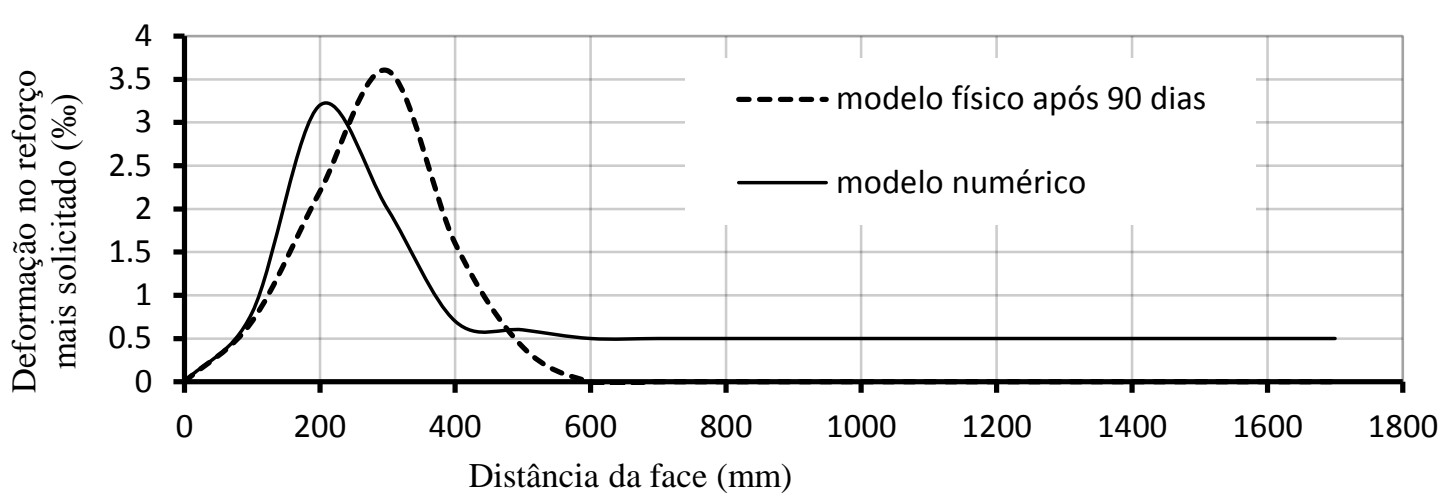

Fonte: Próprio autor

A distância da face onde ocorre a máxima deformação em cada reforço para os modelos físico e numérico está apresentada na Figura 3.10. Segundo Portelinha (2012), a ligação entre os pontos das maiores deformações dos reforços aponta a potencial superfície de ruptura, como mostrado na Figura 2.11.

Figura 3.10 - Comparação entre a potencial superfície de ruptura obtida no modelo físico de Portelinha (2012) e potencial superfície obtida no modelo numérico

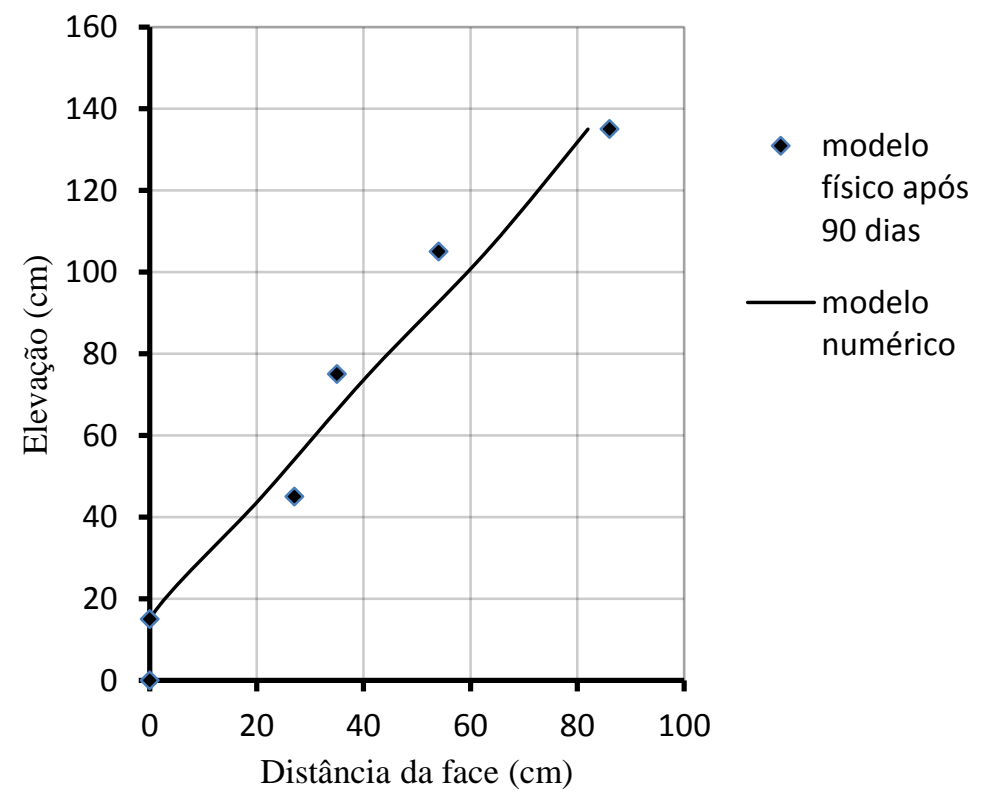

Fonte: Próprio autor 
Conclui-se que o efeito da compactação pode ser simulado na modelagem numérica por meio da construção por etapas, da utilização do modelo constitutivo soil hardening, da representação do esforço de compactação por uma carga estática vertical aplicada e pela imposição de um deslocamento pequeno na base do muro. Contudo, os resultados ainda não foram totalmente satisfatórios e não foram utilizados para as simulações posteriores.

\subsection{ESTUDO PARAMÉTRICO NO MODELO NUMÉRICO}

A partir do modelo calibrado, foram realizadas simulações para estudar o efeito da rigidez do reforço e do solo no comportamento do muro. Foram realizadas simulações com 5 tipos de solo e 4 tipos de reforços.

Utilizaram-se parâmetros de quatro solos tropicais sugeridos por Ehrlich e Becker (2009) e do solo utilizado no modelo físico (Solo 1), apresentados na Tabela 3.1. Para o reforço, foi adotado um material de comportamento elástico linear, com parâmetros: $E A=11 \mathrm{kN} / \mathrm{m}$, representando o geotêxtil não tecido utilizado no modelo físico; $E A=750 \mathrm{kN} / \mathrm{m}$ e $E A=1700 \mathrm{kN} / \mathrm{m}$ representando dois tipos de geogrelhas utilizadas por Ehrlich e Becker (2009) e EA $=100 \mathrm{kN} / \mathrm{m}$, representando um geotêxtil tecido com valor intermediário entre os dois tipos de materiais.

Tabela 3.1- Parâmetros dos solos tropicais utilizados nas simulações

\begin{tabular}{|c|c|c|c|c|c|c|c|c|c|}
\hline Solo & SUCS & $\begin{array}{c}\gamma \\
\left(\mathrm{kN} / \mathrm{m}^{3}\right)\end{array}$ & $\begin{array}{c}\mathrm{E}_{50} \\
(\mathrm{kPa})\end{array}$ & $\begin{array}{c}\mathrm{E}_{\mathrm{oed}} \\
(\mathrm{kPa})\end{array}$ & $\begin{array}{c}\mathrm{E}_{\mathrm{ur}} \\
(\mathrm{kPa})\end{array}$ & $\mathrm{m}$ & $v$ & $\begin{array}{c}\mathrm{C} \\
(\mathrm{kPa})\end{array}$ & $\varphi\left(^{\circ}\right)$ \\
\hline 1 & $\mathrm{SC}$ & 20 & 5.667 & 5.667 & 17,000 & 1 & 0,3 & 32 & 25 \\
\hline 2 & $\mathrm{SM}$ & 20 & 20.000 & 20.000 & 60.000 & 1 & 0,3 & 20 & 36 \\
\hline 3 & $\mathrm{ML}$ & 18 & 6.667 & 6.667 & 20.00 & 1 & 0,3 & 20 & 28 \\
\hline 4 & $\mathrm{MH}$ & 16 & 10.000 & 10.000 & 30.000 & 1 & 0,3 & 25 & 25 \\
\hline 5 & $\mathrm{CL}$ & 17 & 4.667 & 4.667 & 14.000 & 1 & 0,3 & 15 & 28 \\
\hline
\end{tabular}

Fonte: Próprio autor

SUCS: Sistema Unificado de Classificação de Solos; $\gamma$ : peso específico aparente; $E_{50}$ : módulo de deformabilidade no carregamento; $\mathrm{E}_{\text {oed: }}$ módulo de deformabilidade oedométrico; $\mathrm{E}_{\mathrm{ur}}$ : módulo de deformabilidade no recarregamento; $\mathrm{m}$ : expoente empírico da relação entre rigidez e estado de tensão; v: coeficiente de Poisson ; c: coesão; $\varphi$ : ângulo de atrito.

$\mathrm{Na}$ Figura 3.11 e na Figura 3.12 são expostos os maiores deslocamentos calculados da face em função da rigidez do solo e da rigidez do reforço, respectivamente. 
Figura 3.11 - Influência da rigidez do solo no deslocamento máximo da face

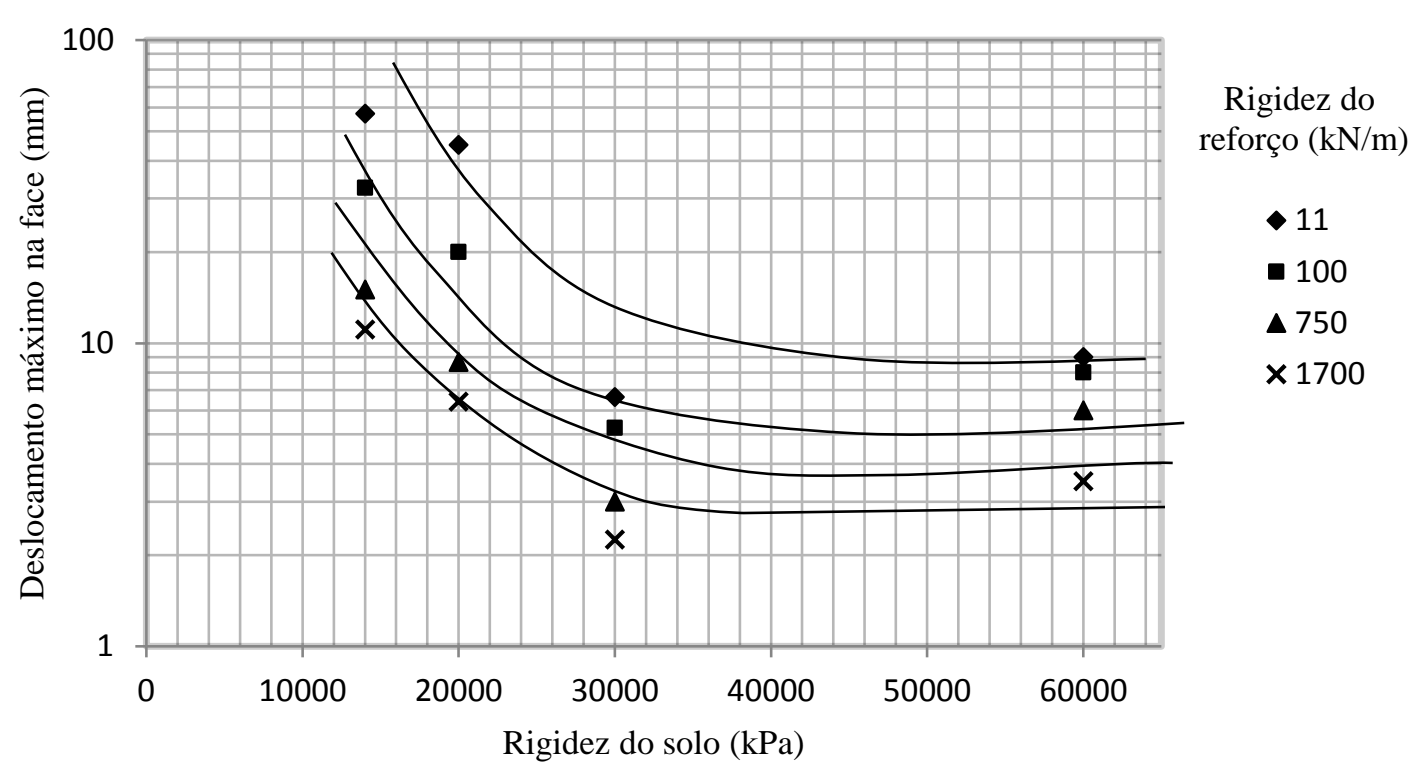

Fonte: Próprio autor

A Figura 3.11 mostra que, para um determinado valor de rigidez do trforço, os deslocamentos máximos na face diminuem significativamente quando aumenta a rigidez do solo de 10.000 a $30.000 \mathrm{kPa}$ e mantém-se praticamente constantes para valores de rigidez do solo maiores do que $30.000 \mathrm{kPa}$, entre $3 \mathrm{~mm}$ (rigidez do reforço de $1700 \mathrm{kN} / \mathrm{m}$ ) e $9 \mathrm{~mm}$ (rigidez do reforço de $11 \mathrm{kN} / \mathrm{m}$ ). As diferenças entre o deslocamento máximo da face para rigidez do reforço máxima e mínima também diminuem significativamente com o aumento da rigidez do solo (observa-se que o eixo das ordenadas na Figura 3.11 está na escala logarítmica).

Quando a rigidez do solo é baixa, evidencia-se a importância da rigidez do reforço. Por exemplo, para solo com rigidez de $20.000 \mathrm{kPa}$, os máximos deslocamentos variaram entre $7 \mathrm{~mm}$ e $45 \mathrm{~mm}$ para rigidez do reforço de, respectivamente, $1700 \mathrm{kN} / \mathrm{m}$ e $11 \mathrm{kN} / \mathrm{m}$. Realmente, o estudo de Helwany; Reardon e Wu (1999) apontou que o tipo de aterro tem profundo efeito sobre o comportamento de muros de solos reforçados, sendo que a rigidez do reforço tem um efeito mais pronunciado quando o solo utilizado tem menor rigidez e resistência ao cisalhamento. 
Figura 3.12 - Influência da rigidez do reforço no deslocamento máximo da face

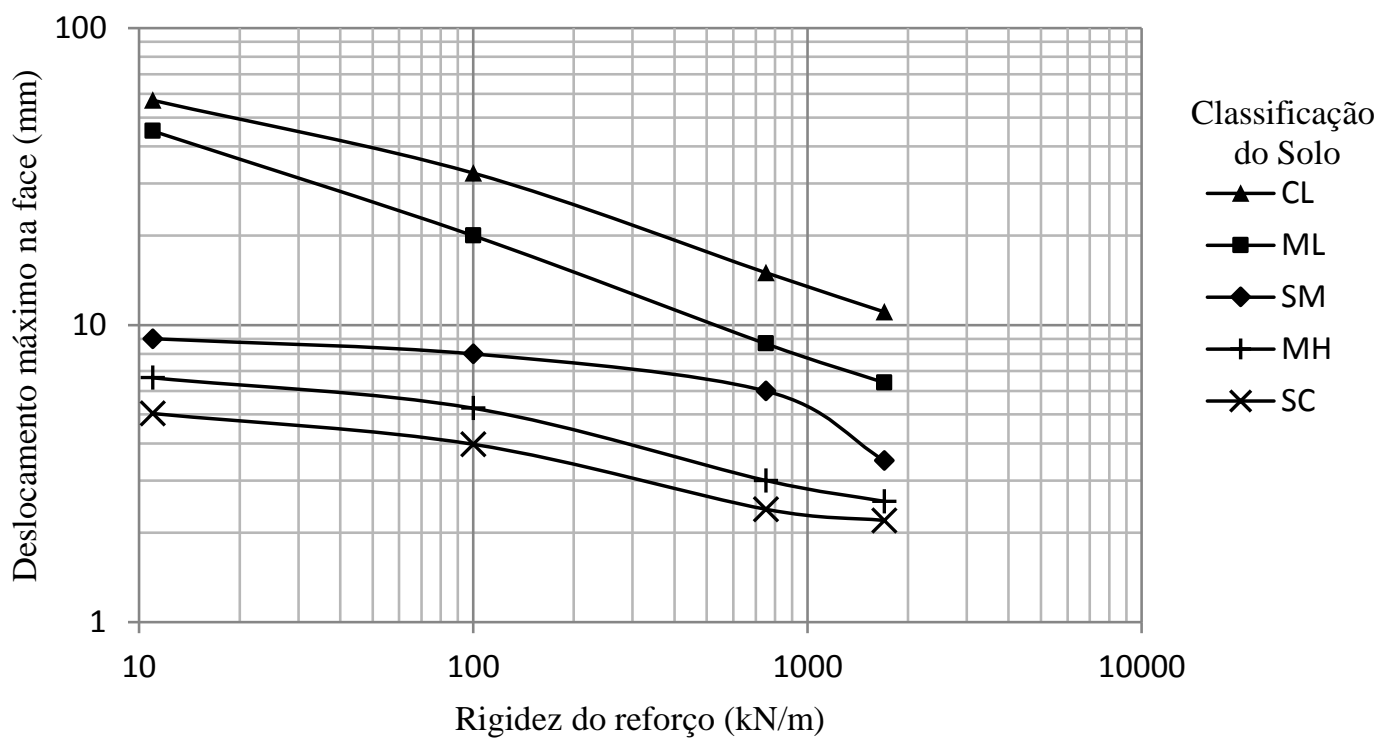

Fonte: Próprio autor

A influência da rigidez do reforço é mais importante para os solos CL e ML do que para os solos $\mathrm{MH}$, SM e SC. Para o solo $\mathrm{CL}$, por exemplo, o deslocamento máximo na face diminui de $70 \mathrm{~mm}$ para $10 \mathrm{~mm}$ quando a rigidez do reforço aumenta de $11 \mathrm{kN} / \mathrm{m}$ para $1700 \mathrm{kN} / \mathrm{m}$. Para o solo SC, esta redução é menos importante, de 5 $\mathrm{mm}$ para $2 \mathrm{~mm}$.

Os parâmetros de resistência e deformabilidade variam entre os solos, portanto não fica claro o fator de maior influência, indicando a necessidade de estudar a variação paramétrica mais sistematicamente.

Na Figura 3.13 são expostas as deformações máximas no reforço em função da rigidez do solo, e na Figura 3.14, o esforço mobilizado do reforço (deformação vezes o módulo de rigidez) em função da rigidez do reforço. 
Figura 3.13 - Influência da rigidez do reforço na deformação máxima no reforço

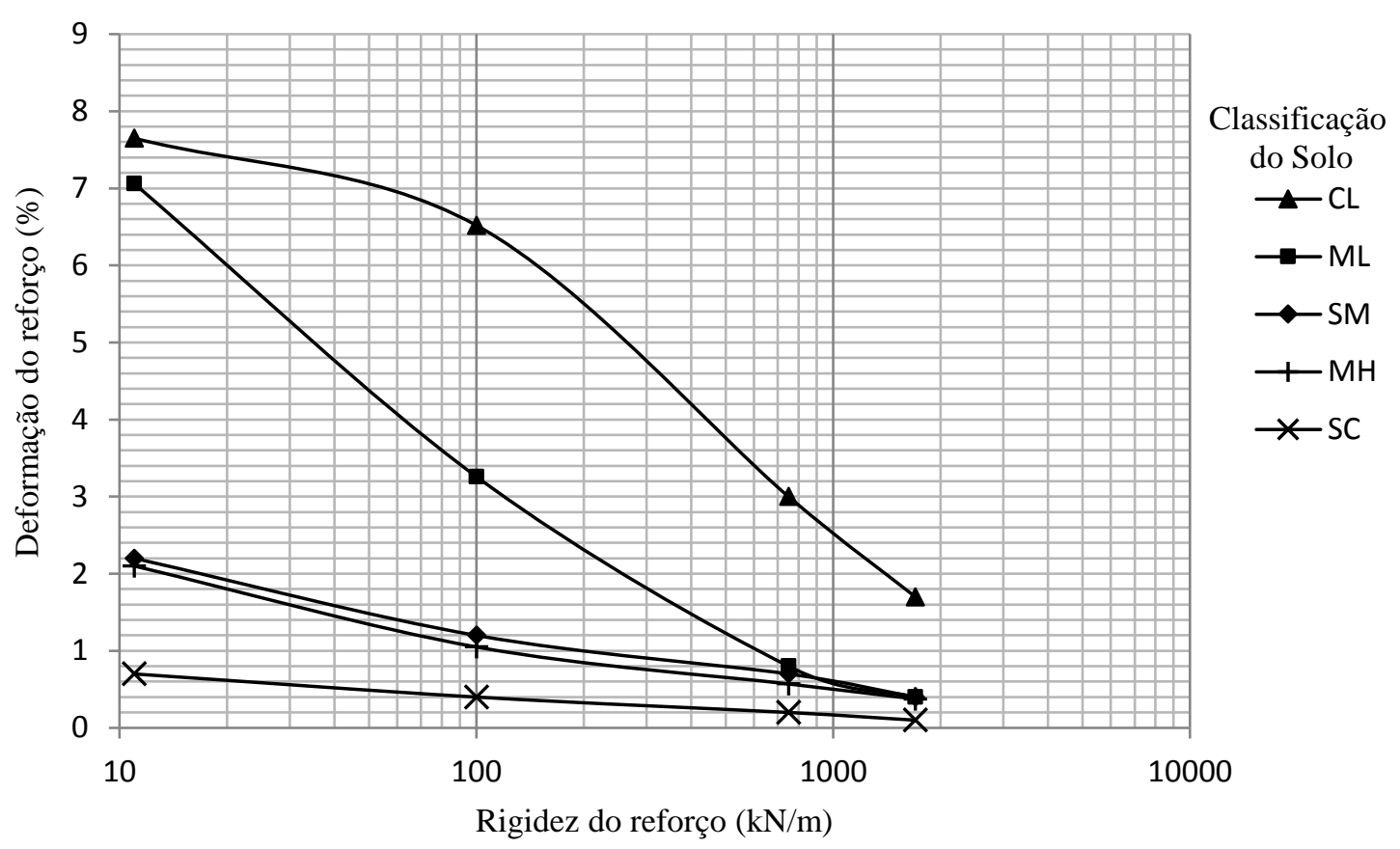

Fonte: Próprio autor

O tipo de solo é realmente fundamental em relação às máximas deformações, como apontado por Helwany; Reardon e Wu (1999). As deformações máximas no reforço para os solos CL e ML variam de 7,1\%-7,6\% para menos de $2 \%$ quando a rigidez do reforço aumenta de $11 \mathrm{kN} / \mathrm{m}$ para $1700 \mathrm{kN} / \mathrm{m}$. Para os demais solos, esta variação é pouco significativa e a deformação máxima é inferior ao valor de $3 \%$ sugerido como limite por Portelinha (2012).

Observa-se que um MSRG construído com o solo classificado como ML apresentaria maiores deformações no reforço do que se construído com o solo classificado como $\mathrm{MH}$. Embora se espere que um solo menos plástico cause menores deformações do que um solo mais plástico, deve-se lembrar que neste caso o solo ML tem menor módulo de deformabilidade do que o solo $\mathrm{MH}$. Esses valores referem-se a solos tropicais brasileiros, para os quais o Sistema Unificado de Classificação dos Solos nem sempre se relaciona satisfatoriamente com o comportamento observado. 
Figura 3.14 - Influência da rigidez do reforço no esforço mobilizado (kN)

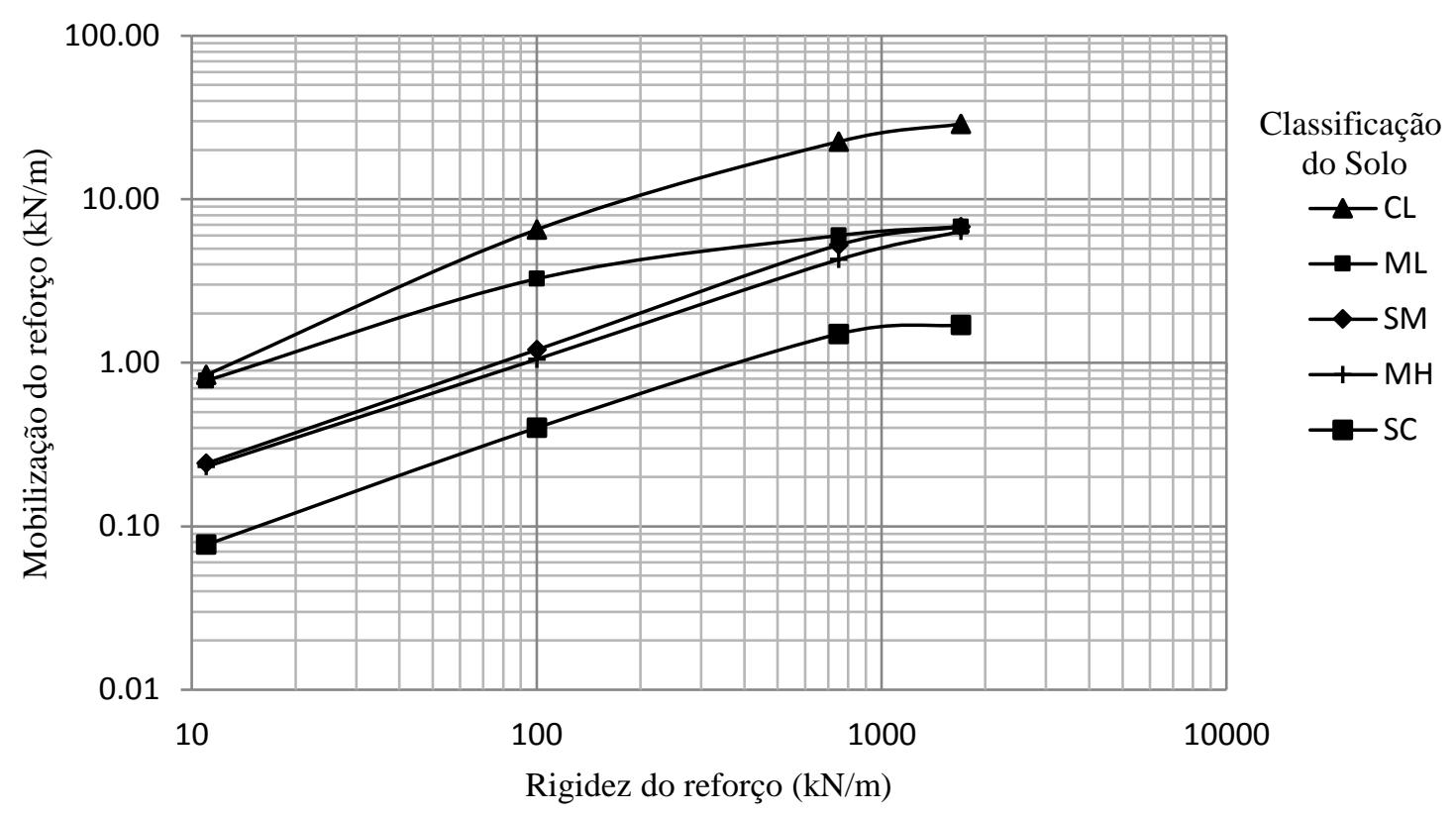

Fonte: Próprio autor

A mobilização do reforço pode variar de uma ordem de grandeza em função do tipo do solo ou, para o mesmo solo, dependendo da rigidez do geossintético. Observa-se que sempre há maior mobilização do reforço com o aumento da rigidez do reforço, independente do tipo de solo. A Figura 3.15 mostra a variação da potencial superfície de ruptura ao se variar o tipo de solo e a rigidez do reforço. Foram selecionadas as combinações que apresentaram deformações extremas.

Figura 3.15 - Influência da variação paramétrica na potencial superfície de ruptura
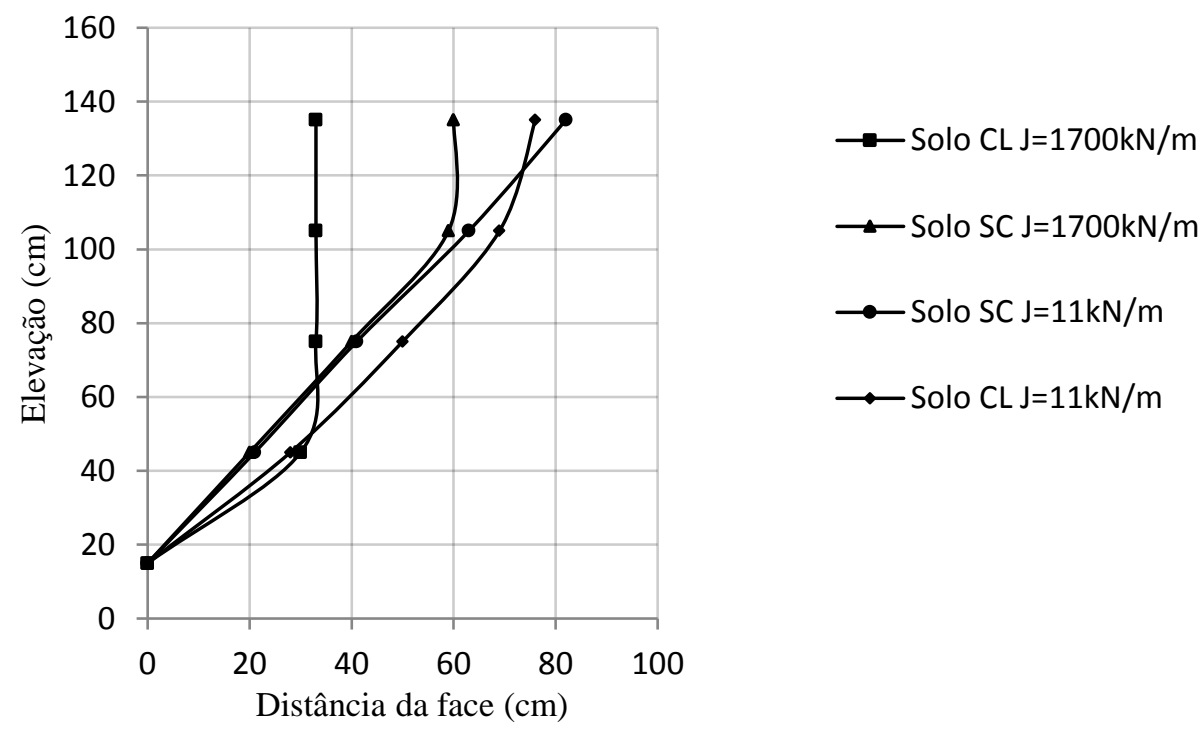
As conclusões preliminares sobre a variação dos parâmetros do solo e do reforço a partir da modelagem numérica de um modelo físico de solo reforçado com geossintético foram:

- O uso de reforço mais rígido de fato contribuiria para que houvesse menores deslocamentos e deformações na estrutura, visto que ela não romperia se construída com qualquer um dos solos investigados.

- A importância do módulo de rigidez do geossintético depende do solo com que é construído o muro.

- Conforme esperado, o solo utilizado na calibração do modelo (SC) teve um desempenho melhor que os solos finos baseados na literatura (CL, $\mathrm{ML}, \mathrm{MH}$ e SM), que tinham valores de resistência e deformabilidade conservativos.

- Reforços mais rígidos contribuem mais para a resistência do muro de solo reforçado, pois mesmo havendo menores deformações internas, as forças mobilizadas pelos reforços mais rígidos foram maiores, solicitando menos o solo. 


\section{MODELAGEM NUMÉRICA DE UM MSRG HIPOTÉTICO}

Com o conhecimento adquirido através da construção e calibração do modelo numérico baseado no modelo físico de Portelinha (2012), foi possível criar um modelo genérico de MSRG e estudar mais detalhadamente as variações paramétricas, quais sejam, diferentes alturas, reforços e solos. Nesse modelo as tensões são devidas ao peso próprio do muro (no modelo físico a bolsa procurava representar uma determinada altura de muro) e é adotada uma seção transversal considerando-se um estado plano de deformação.

\subsection{CONSTRUÇÃO DO MODELO NUMÉRICO DE MSRG}

De forma geral o modelo numérico de MSRG foi construído com as seguintes características:

- Seção transversal de $50 \mathrm{~m}$ de largura e altura de até $20 \mathrm{~m}$;

- O muro não tem ficha;

- Elementos finitos de 15 nós;

- Malha mais refinada possível (o número de elementos variou, portanto, com a altura do muro);

- Comprimento do reforço variável;

- Condições de contorno:

A base tem com 3 vínculos (sem deslocamentos e rotação), com elementos de rigidez muito elevada $\left(10^{11} \mathrm{MPa}\right)$;

A face exposta do muro é livre, podendo se deslocar horizontalmente, verticalmente e girar (sem vínculos);

A face superior (topo) do muro também sem restrição de deslocamento e rotação (sem vínculos); 
A face do fundo do muro sem deslocamento horizontal nem rotação, só deslocamento vertical (2 vínculos);

- Espaçamento constante entre as camadas de reforços geossintéticos e a aplicação de reforços de mesma rigidez;

- Solo com comportamento elasto-plástico com critério de ruptura de MohrCoulomb;

- Reforço com comportamento elástico linear com critério de ruptura de deformação máxima de 3\%;

- Inclinação constante da face;

- Não consideração do ganho de resistência do aterro reforçado devido à face.

Embora na prática sejam comuns os espaçamentos diferentes e a composição de diferentes tipos de reforços, nas simulações numéricas foram adotados valores constantes. Essa simplificação é adotada porque o foco principal do estudo é a influência dos parâmetros de rigidez e resistência do solo e do reforço. Além disso, o arranjo ideal varia muito de acordo com o local e disponibilidade de materiais, tendo em vista a praticidade na execução, o custo do reforço, o ganho em economia de escala e a disponibilidade técnica na instalação.

Outra simplificação adotada foi não haver ficha na construção do muro, substituída por uma condição de restrição de deslocamentos horizontais e verticais na primeira camada. Na prática o aprofundamento do muro (ficha) tem a intenção de evitar que ocorra a ruptura do muro pela fundação por capacidade de carga ou ruptura generalizada, e que não ocorra a ruptura por deslizamento. A profundidade da ficha é dimensionada a partir do tipo de solo da fundação e altura do muro, e como esses parâmetros são variados ao longo do estudo, a ficha foi substituída pelas condições de contorno que ela dá à estrutura.

A simulação numérica tem como limitação não considerar a ruptura e 0 arrancamento do reforço, limitando-se ao escoamento plástico do elemento (o significa que após atingir determinada tensão máxima, essa tensão se mantém e há 
uma redistribuição de cargas na estrutura até se atingir a estabilidade interna). Como essas variáveis dependem também do tipo de reforço, e não apenas de sua rigidez, uma deformação excessiva pode implicar em diferentes formas de ruptura, como: arrancamento do reforço, ruptura do reforço ou mesmo o escoamento plástico, conforme o modelo numérico. A fim de englobar essas hipóteses nas simulações numéricas foi interpretada como ruptura a deformação máxima de $3 \%$ no reforço. Esse valor foi um valor médio apresentado como ruptura nos estudos de Benjamim (2006) e por Koerner e Koerner (2013).

Não foi simulado o efeito da compactação do solo nesta etapa, apesar dos resultados razoáveis obtidos no item 3.3. Na calibração do modelo físico, compararam-se os valores medidos de deslocamentos com os calculados pelo modelo numérico somente devido à carga aplicada, uma vez que os deslocamentos devidos ao peso do solo e à compactação eram zerados em cada etapa construtiva. Caso se procedesse da mesma forma na simulação numérica de um MSRG sem carga aplicada na superfície, os deslocamentos calculados finais seriam nulos.

A Figura 4.1 mostra o modelo numérico de MSRG, para o caso de muro com 20 $\mathrm{m}$ de altura, reforço de comprimento igual a $80 \%$ da altura, e inclinação da face de $1 \mathrm{~V}: 9 \mathrm{H}$. 
Figura 4.1 - Modelo numérico do MSRG

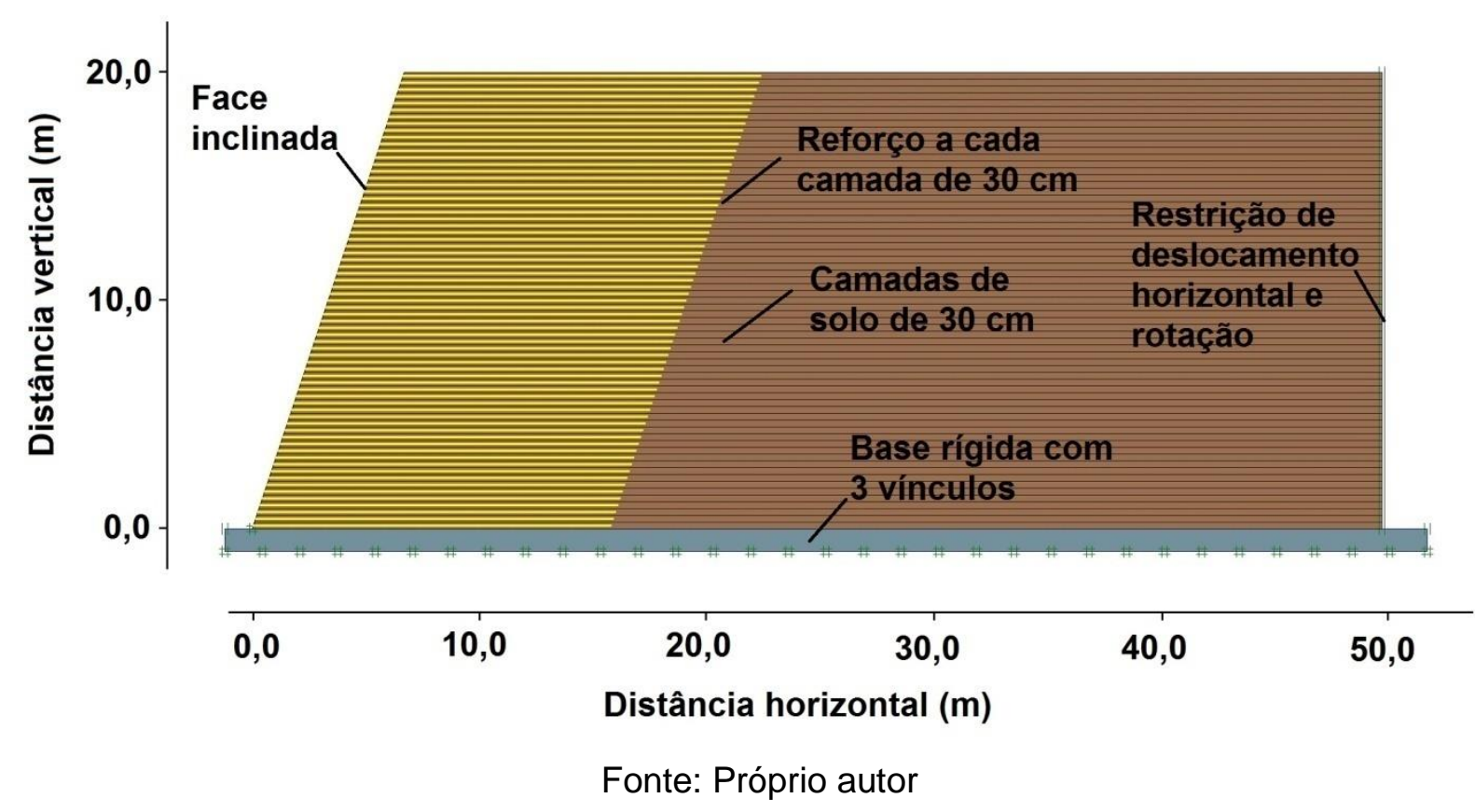

\subsection{SIMULAÇÕES DO MODELO NUMÉRICO DE MSRG COM ALTEAMENTOS SUCESSIVOS COM TRÊS SOLOS TROPICAIS}

A fim de avaliar o comportamento da estrutura construída com solos tropicais, foram selecionados três solos dentre os cinco analisados anteriormente, com valores extremos e valor médio de módulo de elasticidade: SM, MH e CL. Os dados dos solos encontram-se na Tabela 3.1, adotando-se modelo constitutivo elasto-plástico com critério de escoamento de Mohr-Coulomb, com o valor de E (módulo de elasticidade do solo) igual ao de $\mathrm{E}_{\mathrm{ur}}$ do hardening soil model.

As simulações foram de um muro com alteamento progressivo de 0,90 $\mathrm{m}$ até atingir a altura de $20 \mathrm{~m}$ ou até a ruptura, inclinação da face $3 \mathrm{~V}: 1 \mathrm{H}$, espaçamento entre reforços de $0,30 \mathrm{~m}$, comprimento do reforço de $20 \mathrm{~m}$. Variou-se a rigidez do reforço (11 a $500 \mathrm{kN} / \mathrm{m})$ para cada solo.

Foi utilizada uma malha com 7460 elementos e 60.209 nós. Nos cenários mais críticos (muro com $20 \mathrm{~m}$ de altura), o tempo de processamento foi de aproximadamente 1,5 horas.

As simulações do modelo físico com solos tropicais foram nomeadas com a sigla "ALT", apresentados na Tabela 4.1. 
Tabela 4.1- Variação paramétrica do modelo físico com três solos tropicais e alteamento sucessivo até $20 \mathrm{~m}$

\begin{tabular}{|c|c|c|}
\hline $\begin{array}{c}\text { Nome da } \\
\text { simulação }\end{array}$ & $\begin{array}{c}\text { Solo } \\
\text { (Tabela 3.1) }\end{array}$ & $\begin{array}{c}\text { Rigidez do } \\
\text { reforço } \mathbf{( k N / m )}\end{array}$ \\
\hline ALT 1 & 2 & 11 \\
\hline ALT 2 & 2 & 100 \\
\hline ALT 3 & 2 & 500 \\
\hline ALT 4 & 4 & 11 \\
\hline ALT 5 & 4 & 100 \\
\hline ALT 6 & 4 & 500 \\
\hline ALT 7 & 5 & 11 \\
\hline ALT 8 & 5 & 100 \\
\hline ALT 9 & 5 & 500 \\
\hline
\end{tabular}

Fonte: Próprio autor

\subsection{SIMULAÇÕES DO MODELO NUMÉRICO DE MSRG COM ALTEAMENTOS SUCESSIVOS COM SOLOS HIPOTÉTICOS}

Para isolar o efeito de cada variação paramétrica, simulou-se um muro com alteamento sucessivo até $10 \mathrm{~m}$ de altura, solo elástico perfeitamente plástico com critério de escoamento de Mohr-Coulomb, com peso específico seco de $20 \mathrm{kN} / \mathrm{m}^{3}$, coeficiente de Poisson igual a 0,3, espaçamento entre reforços de $30 \mathrm{~cm}$, inclinação da face 3V:1H. Variaram-se os seguintes parâmetros: coesão do solo (1 a $40 \mathrm{kPa}$ ), ângulo de atrito do solo (10 a 40), módulo de elasticidade do solo (10 a $60 \mathrm{MPa}$ ), módulo de rigidez do reforço (11 a $500 \mathrm{kN} / \mathrm{m}$ ) e comprimento de reforço (5 a $10 \mathrm{~m}$ ).

Nessas simulações as combinações entre coesão (c), ângulo de atrito $(\varphi)$ e módulo de deformabilidade do solo (E) não correspondem a solos encontrados na natureza, mas facilitam a compreensão da influência desses parâmetros no comportamento do muro de solo reforçado. A variação paramétrica foi simulada utilizando combinações dos parâmetros mostrados na Tabela 4.2 
Tabela 4.2-Variação dos parâmetros nas simulações

\begin{tabular}{|c|c|}
\hline Rigidez do reforço (kN/m) & 11,100 e 500 \\
\hline Altura máxima do muro $(\mathbf{m})$ & 5 e 10 \\
\hline $\mathbf{c ~}\left(\mathbf{k N} / \mathbf{m}^{2}\right)$ & 0,20 e 40 \\
\hline$\varphi^{\circ}$ & 10,20 e 40 \\
\hline $\mathbf{E}\left(\mathbf{k N} / \mathbf{m}^{2}\right)$ & $10.000,20.000$ e 60.000 \\
\hline
\end{tabular}

Fonte: Próprio autor

As demais variáveis do modelo se mantém iguais em todas as simulações, sendo elas: peso do solo: $20 \mathrm{kN} / \mathrm{m}^{3}$ e coeficiente de Poisson: 0,3 e alteamento sucessivo e inclinação de face $1 \mathrm{~V}: 3 \mathrm{H}$.

Neste momento percebeu-se que para muros construídos com solo sem coesão o software apontava ruptura entre duas camadas de reforço, o que não ocorre na realidade devido ao envelopamento do muro pelo geossintético. Decidiuse utilizar o elemento Plate do software para representar um muro de face flexível com envelopamento, de modo que o solo não ficasse solto. Os parâmetros do elemento tipo Plate na face foram selecionados para ter pouca rigidez, somente para confinar o solo. No elemento Plate foi adotado $w=0 \mathrm{KN} / \mathrm{m} / \mathrm{m}, E A=60 \mathrm{KN} / \mathrm{m}$ e $\mathrm{El}=1,0$ $\mathrm{KN} / \mathrm{m}^{2} / \mathrm{m}$, representando assim uma face sem contribuição significativa, sendo w o peso linear, E o módulo de deformabilidade, A a área e I o momento de inércia. Foram refeitas algumas simulações, que confirmaram que esta solução não influencia na deformada final do muro, só evita a ruptura localizada. Nas simulações seguintes, foram incorporados os elementos Plate na face do MSRG.

Os parâmetros das simulações estão apresentados com a sigla "PARA" na Tabela 4.3. 
Tabela 4.3 - Variação paramétrica com alteamento sucessivo

\begin{tabular}{|c|c|c|c|c|}
\hline $\begin{array}{l}\text { Nome da } \\
\text { simulação }\end{array}$ & $\begin{array}{l}\text { Rigidez do } \\
\text { reforço } \\
(\mathrm{kN} / \mathrm{m})\end{array}$ & c kN/m² & $\varphi^{\circ}$ & $\begin{array}{c}E \\
k N / m^{2}\end{array}$ \\
\hline PARA 1 & 11 & 1 & 10 & 10.000 \\
\hline PARA 2 & 11 & 1 & 20 & 10.000 \\
\hline PARA 3 & 11 & 1 & 40 & 10.000 \\
\hline PARA 4 & 11 & 20 & 20 & 10.000 \\
\hline PARA 5 & 11 & 20 & 20 & 60.000 \\
\hline PARA 6 & 11 & 40 & 20 & 10.000 \\
\hline PARA 7 & 100 & 20 & 20 & 10.000 \\
\hline PARA 8 & 100 & 20 & 20 & 10.000 \\
\hline PARA 9 & 100 & 20 & 20 & 10.000 \\
\hline PARA 10 & 500 & 40 & 40 & 60.000 \\
\hline PARA 11 & 11 & 20 & 20 & 10.000 \\
\hline PARA 12 & 500 & 0 & 40 & 10.000 \\
\hline
\end{tabular}

\subsection{SIMULAÇÕES DE MSRG DE 10 M DE ALTURA COM VARIAÇÃO PARAMÉTRICA}

Para completar a análise da influência dos parâmetros do solo, realizaram-se então simulações fixando-se: altura do muro de $10 \mathrm{~m}$ (altura plena, sem alteamento sucessivos), reforço de $8 \mathrm{~m}$ equivalentes a $80 \%$ da altura do muro, rigidez do reforço de $1.000 \mathrm{kN} / \mathrm{m}$, espaçamento do reforço de $30 \mathrm{~cm}$, inclinação da face de $9 \mathrm{~V}: 1 \mathrm{H}$, coeficiente de Poisson igual a 0,3. Variaram-se os seguintes parâmetros do solo: coesão (10 a $60 \mathrm{kPa}$ ), ângulo de atrito $\left(10\right.$ a $30^{\circ}$ ) e módulo de rigidez (10 a $60 \mathrm{MPa}$ ).

A influência da inclinação do muro foi estudada para um muro de $10 \mathrm{~m}$ de altura (altura plena, sem alteamento sucessivos), reforço de $8 \mathrm{~m}$ equivalentes a $80 \%$ da altura do muro, rigidez do reforço de $1.000 \mathrm{kN} / \mathrm{m}$, espaçamento do reforço de 30 cm, coeficiente de Poisson igual a 0,3. Variaram-se os seguintes parâmetros do solo: coesão (20 a $60 \mathrm{kPa}$ ), ângulo de atrito (10 a 30) e módulo de rigidez do solo (10 a $60 \mathrm{MPa}$ ), com três inclinações: 3V:1H, 6V: 1H, 9V:1H.

Para compreender a influência do espaçamento vertical e a equivalência entre combinações de espaçamento e rigidez de geossintético proposta pela FHWAHRT-14-094 (2015), realizaram-se simulações com muro de $10 \mathrm{~m}$ de altura (altura plena, sem alteamento sucessivos), reforço de $8 \mathrm{~m}$ equivalentes a $80 \%$ da altura do 
muro, inclinação do muro de $9 \mathrm{~V}: 1 \mathrm{H}$ e módulo de rigidez do solo de $30 \mathrm{MPa}$. Estudaram-se os casos de solo não coesivo ( $\mathrm{c}=1 \mathrm{kPa}$ e $\left.\varphi=30^{\circ}\right)$, solo coesivo com baixa coesão $\left(\mathrm{C}=20 \mathrm{kPa}\right.$ e $\left.\varphi=20^{\circ}\right)$ e solo coesivo com alta coesão ( $\mathrm{C}=40 \mathrm{kPa}$ e $\left.\varphi=20^{\circ}\right)$. Os espaçamentos estudados foram de 0,30 a $1,20 \mathrm{~m}$ e a rigidez do reforço de 10 a $1000 \mathrm{KN} / \mathrm{m}$.

As simulações com o intuito de estudar a influência dos parâmetros do solo no modelo numérico de MSRG sem o alteamento foram nomeadas com a sigla "PAR", apresentados na Tabela 4.4, sempre utilizando um reforço com rigidez de 1.000 (kN/m). Variaram-se os seguintes parâmetros do solo: coesão (10, 20, 40 e $60 \mathrm{kPa})$, ângulo de atrito $\left(10,20\right.$ e $\left.30^{\circ}\right)$ e módulo de rigidez (10, 20, 40 e $\left.60 \mathrm{MPa}\right)$.

Tabela 4.4 - Variação paramétrica sem alteamento progressivo com foco no solo

\begin{tabular}{|l|c|c|c|}
\hline $\begin{array}{l}\text { Nome da } \\
\text { simulação }\end{array}$ & $\mathbf{c} \mathbf{k N} / \mathbf{m}^{\mathbf{2}}$ & $\boldsymbol{\varphi}^{\circ}$ & $\mathbf{E} \mathbf{k N} / \mathbf{m}^{\mathbf{2}}$ \\
\hline PAR 1 & 10 & 10 & 10.000 \\
\hline PAR 2 & 10 & 20 & 20.000 \\
\hline PAR 3 & 10 & 30 & 40.000 \\
\hline PAR 4 & 10 & 10 & 60.000 \\
\hline PAR 5 & 10 & 20 & 10.000 \\
\hline PAR 6 & 10 & 30 & 20.000 \\
\hline PAR 7 & 10 & 10 & 40.000 \\
\hline PAR 8 & 10 & 20 & 60.000 \\
\hline PAR 9 & 10 & 30 & 10.000 \\
\hline PAR 10 & 10 & 10 & 20.000 \\
\hline PAR 11 & 10 & 20 & 40.000 \\
\hline PAR 12 & 10 & 30 & 60.000 \\
\hline PAR 13 & 20 & 10 & 10.000 \\
\hline PAR 14 & 20 & 20 & 10.000 \\
\hline PAR 15 & 20 & 30 & 10.000 \\
\hline PAR 16 & 20 & 10 & 20.000 \\
\hline PAR 17 & 20 & 20 & 20.000 \\
\hline PAR 18 & 20 & 30 & 20.000 \\
\hline PAR 19 & 20 & 10 & 40.000 \\
\hline PAR 20 & 20 & 20 & 40.000 \\
\hline PAR 21 & 20 & 30 & 40.000 \\
\hline PAR 22 & 20 & 10 & 60.000 \\
\hline PAR 23 & 20 & 20 & 60.000 \\
\hline
\end{tabular}

\begin{tabular}{|l|l|l|l|}
\hline PAR 24 & 20 & 30 & 60.000 \\
\hline PAR 25 & 40 & 10 & 10.000 \\
\hline PAR 26 & 40 & 20 & 10.000 \\
\hline PAR 27 & 40 & 30 & 10.000 \\
\hline PAR 28 & 40 & 10 & 20.000 \\
\hline PAR 29 & 40 & 20 & 20.000 \\
\hline PAR 30 & 40 & 30 & 20.000 \\
\hline PAR 31 & 40 & 10 & 40.000 \\
\hline PAR 32 & 40 & 20 & 40.000 \\
\hline PAR 33 & 40 & 30 & 40.000 \\
\hline PAR 34 & 40 & 10 & 60.000 \\
\hline PAR 35 & 40 & 20 & 60.000 \\
\hline PAR 36 & 40 & 30 & 60.000 \\
\hline PAR 37 & 60 & 10 & 10.000 \\
\hline PAR 38 & 60 & 20 & 10.000 \\
\hline PAR 39 & 60 & 30 & 10.000 \\
\hline PAR 40 & 60 & 10 & 20.000 \\
\hline PAR 41 & 60 & 20 & 20.000 \\
\hline PAR 42 & 60 & 30 & 20.000 \\
\hline PAR 43 & 60 & 10 & 40.000 \\
\hline PAR 44 & 60 & 20 & 40.000 \\
\hline PAR 45 & 60 & 30 & 40.000 \\
\hline PAR 46 & 60 & 10 & 60.000 \\
\hline PAR 47 & 60 & 20 & 60.000 \\
\hline PAR 48 & 60 & 30 & 60.000 \\
\hline
\end{tabular}


As simulações com o intuito de estudar a influência da inclinação da face no modelo numérico de MSRG sem o alteamento sucessivo foram nomeadas com a sigla "INCL", apresentados na Tabela 4.5, sempre utilizando um reforço com rigidez de $1.000 \mathrm{kN} / \mathrm{m}$ e com inclinações 3V:1H, 6V:1H ou 9V:1H.

Tabela 4.5 - Variação paramétrica sem alteamento progressivo com foco na inclinação

\begin{tabular}{|l|c|c|c|c|}
\hline $\begin{array}{c}\text { Nome da } \\
\text { simulação }\end{array}$ & $\begin{array}{c}\text { Inclinação } \\
\text { da face }\end{array}$ & $\mathbf{c ~ k N / \mathbf { m } ^ { 2 }}$ & $\varphi^{\circ}$ & $\mathbf{E ~} \mathbf{~ N} / \mathbf{m}^{2}$ \\
\hline INCL 1 & $3 \mathrm{~V}: 1 \mathrm{H}$ & 20 & 10 & 10.000 \\
\hline INCL 2 & $3 \mathrm{~V}: 1 \mathrm{H}$ & 20 & 20 & 10.000 \\
\hline INCL 3 & $3 \mathrm{~V}: 1 \mathrm{H}$ & 20 & 30 & 10.000 \\
\hline INCL 4 & $6 \mathrm{~V}: 1 \mathrm{H}$ & 20 & 10 & 10.000 \\
\hline INCL 5 & $6 \mathrm{~V}: 1 \mathrm{H}$ & 20 & 20 & 10.000 \\
\hline INCL 6 & $6 \mathrm{~V}: 1 \mathrm{H}$ & 20 & 30 & 10.000 \\
\hline INCL 7 & $9 \mathrm{~V}: 1 \mathrm{H}$ & 20 & 10 & 10.000 \\
\hline INCL 8 & $9 \mathrm{~V}: 1 \mathrm{H}$ & 20 & 20 & 10.000 \\
\hline INCL 9 & $9 \mathrm{~V}: 1 \mathrm{H}$ & 20 & 30 & 10.000 \\
\hline INCL 10 & $3 \mathrm{~V}: 1 \mathrm{H}$ & 20 & 10 & 60.000 \\
\hline INCL 11 & $3 \mathrm{~V}: 1 \mathrm{H}$ & 20 & 20 & 60.000 \\
\hline INCL 12 & $3 \mathrm{~V}: 1 \mathrm{H}$ & 20 & 30 & 60.000 \\
\hline INCL 13 & $6 \mathrm{~V}: 1 \mathrm{H}$ & 20 & 10 & 60.000 \\
\hline INCL 14 & $6 \mathrm{~V}: 1 \mathrm{H}$ & 20 & 20 & 60.000 \\
\hline INCL 15 & $6 \mathrm{~V}: 1 \mathrm{H}$ & 20 & 30 & 60.000 \\
\hline INCL 16 & $9 \mathrm{~V}: 1 \mathrm{H}$ & 20 & 10 & 60.000 \\
\hline INCL 17 & $9 \mathrm{~V}: 1 \mathrm{H}$ & 20 & 20 & 60.000 \\
\hline INCL 18 & $9 \mathrm{~V}: 1 \mathrm{H}$ & 20 & 30 & 60.000 \\
\hline INCL 19 & $3 \mathrm{~V}: 1 \mathrm{H}$ & 40 & 20 & 10.000 \\
\hline INCL 20 & $6 \mathrm{~V}: 1 \mathrm{H}$ & 40 & 20 & 10.000 \\
\hline INCL 21 & $9 \mathrm{~V}: 1 \mathrm{H}$ & 40 & 20 & 10.000 \\
\hline INCL 22 & $3 \mathrm{~V}: 1 \mathrm{H}$ & 60 & 20 & 10.000 \\
\hline INCL 23 & $6 \mathrm{~V}: 1 \mathrm{H}$ & 60 & 20 & 10.000 \\
\hline INCL 24 & $9 \mathrm{~V}: 1 \mathrm{H}$ & 60 & 20 & 10.000 \\
\hline
\end{tabular}

Fonte: Próprio autor

As simulações com o intuito de estudar a influência do espaçamento vertical e rigidez do reforço no modelo numérico de MSRG sem o alteamento sucessivo foram nomeadas com a sigla "ESP", cujos parâmetros estão apresentados na Tabela 4.6. $\mathrm{O}$ módulo de rigidez do solo (E) sempre foi $30 \mathrm{MPa}$. Variaram-se os seguintes parâmetros do reforço: módulo de rigidez $\left(10,100,500\right.$ e $\left.1.000 \mathrm{kN} / \mathrm{m}^{2}\right)$ e espaçamento $(30,60,90$ e $120 \mathrm{~cm})$. 
Tabela 4.6 - Variação paramétrica sem alteamento progressivo com foco no espaçamento

\begin{tabular}{|c|c|c|c|c|}
\hline $\begin{array}{l}\text { Nome da } \\
\text { simulação }\end{array}$ & $\begin{array}{l}\text { Rigidez do } \\
\text { reforço } \\
(\mathbf{k N} / \mathbf{m})\end{array}$ & $\begin{array}{c}\text { e - } \\
\text { espaçamento } \\
\text { vertical entre } \\
\text { reforços }(\mathrm{cm})\end{array}$ & c kN/m² & $\varphi^{\circ}$ \\
\hline ESP 1 & 10 & 30 & 1 & 30 \\
\hline ESP 2 & 100 & 30 & 1 & 30 \\
\hline ESP 3 & 500 & 30 & 1 & 30 \\
\hline ESP 4 & 1.000 & 30 & 1 & 30 \\
\hline ESP 5 & 10 & 60 & 1 & 30 \\
\hline ESP 6 & 100 & 60 & 1 & 30 \\
\hline ESP 7 & 500 & 60 & 1 & 30 \\
\hline ESP 8 & 1.000 & 60 & 1 & 30 \\
\hline ESP 9 & 10 & 90 & 1 & 30 \\
\hline ESP 10 & 100 & 90 & 1 & 30 \\
\hline ESP 11 & 500 & 90 & 1 & 30 \\
\hline ESP 12 & 1.000 & 90 & 1 & 30 \\
\hline ESP 13 & 10 & 120 & 1 & 30 \\
\hline ESP 14 & 100 & 120 & 1 & 30 \\
\hline ESP 15 & 500 & 120 & 1 & 30 \\
\hline ESP 16 & 1.000 & 120 & 1 & 30 \\
\hline ESP 17 & 10 & 30 & 20 & 20 \\
\hline ESP 18 & 100 & 30 & 20 & 20 \\
\hline ESP 19 & 500 & 30 & 20 & 20 \\
\hline ESP 20 & 1.000 & 30 & 20 & 20 \\
\hline ESP 21 & 10 & 60 & 20 & 20 \\
\hline ESP 22 & 100 & 60 & 20 & 20 \\
\hline ESP 23 & 500 & 60 & 20 & 20 \\
\hline ESP 24 & 1.000 & 60 & 20 & 20 \\
\hline ESP 25 & 10 & 90 & 20 & 20 \\
\hline ESP 26 & 100 & 90 & 20 & 20 \\
\hline ESP 27 & 500 & 90 & 20 & 20 \\
\hline ESP 28 & 1.000 & 90 & 20 & 20 \\
\hline ESP 29 & 10 & 120 & 20 & 20 \\
\hline ESP 30 & 100 & 120 & 20 & 20 \\
\hline ESP 31 & 500 & 120 & 20 & 20 \\
\hline ESP 32 & 1.000 & 120 & 20 & 20 \\
\hline ESP 33 & 500 & 30 & 40 & 20 \\
\hline ESP 34 & 1.000 & 30 & 40 & 20 \\
\hline ESP 35 & 500 & 60 & 40 & 20 \\
\hline ESP 36 & 1.000 & 60 & 40 & 20 \\
\hline ESP 37 & 500 & 90 & 40 & 20 \\
\hline ESP 38 & 1.000 & 90 & 40 & 20 \\
\hline ESP 39 & 500 & 120 & 40 & 20 \\
\hline ESP 40 & 1.000 & 120 & 40 & 20 \\
\hline
\end{tabular}

Fonte: Próprio autor 


\section{RESULTADOS}

\subsection{SIMULAÇÕES DO MODELO NUMÉRICO DE MSRG COM ALTEAMENTOS SUCESSIVOS COM TRÊS SOLOS TROPICAIS.}

A título de exemplo, na Figura 5.1 pode-se observar a deformada de um muro de $15 \mathrm{~m}$ de altura construído com o solo $\mathrm{MH}$ e um reforço de $100 \mathrm{KN} / \mathrm{m}$ de rigidez. As deformações estão ampliadas em 50 vezes para melhor visualização. Nessa situação houve deformações excessivas sem que ocorresse a ruptura da estrutura, pois ela se manteve estável devido à grande contribuição do reforço.

Figura 5.1 - Deformada de um MSRG de 15 m de altura construído com solo MH e reforço de rigidez de $100 \mathrm{kN} / \mathrm{m}$

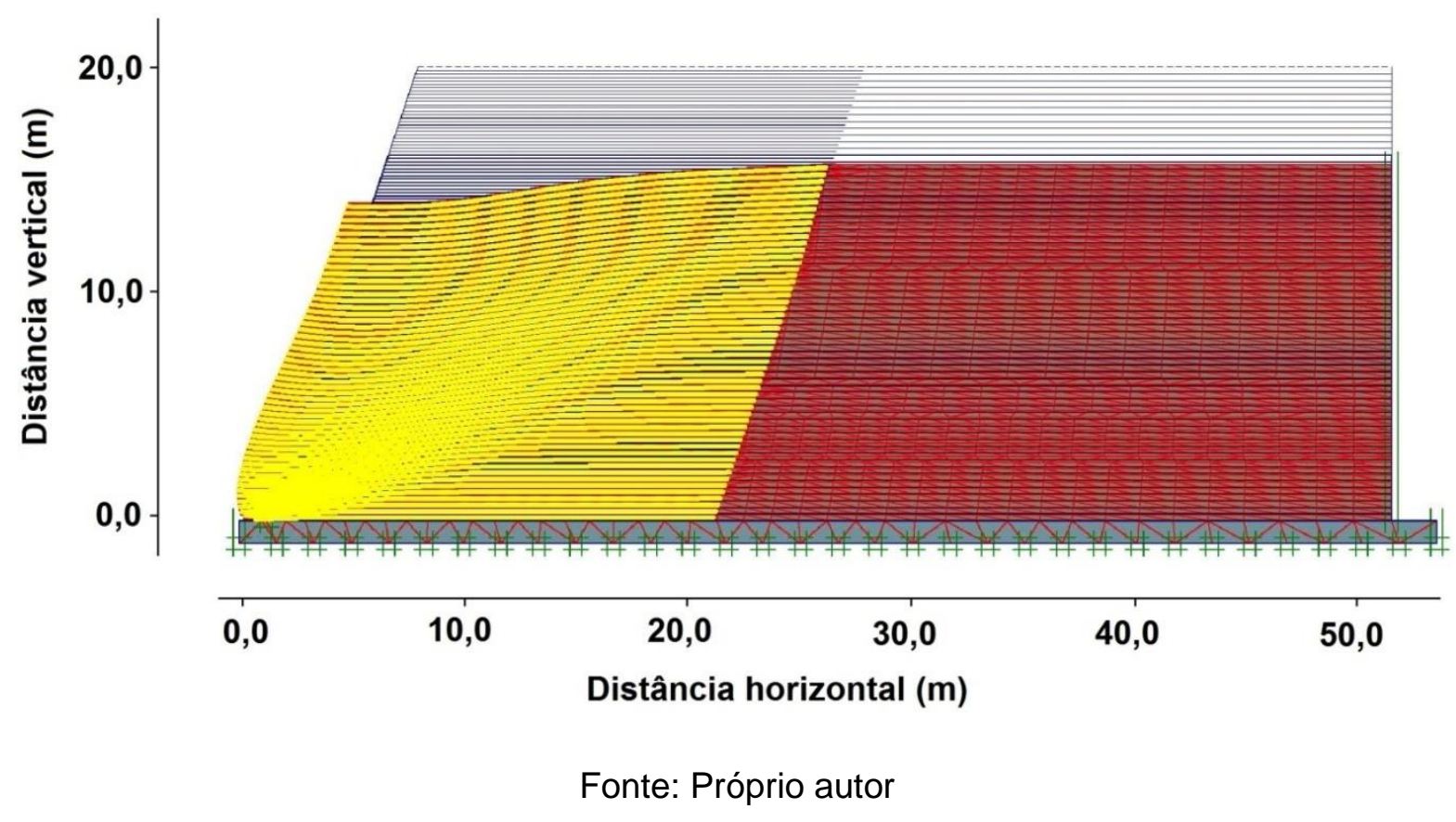

Para analisar a contribuição do reforço, utilizou-se a saída do software força mobilizada no reforço, exemplificada na Figura 5.2 para o reforço da camada inferior, que foi o mais solicitado. Para cada alteamento do muro, obteve-se o valor da máxima força mobilizada no reforço mais solicitado. Esses valores foram utilizados para construir o diagrama de força mobilizada em função da altura do muro. 
Figura 5.2 - Exemplo de distribuição da força mobilizada no reforço
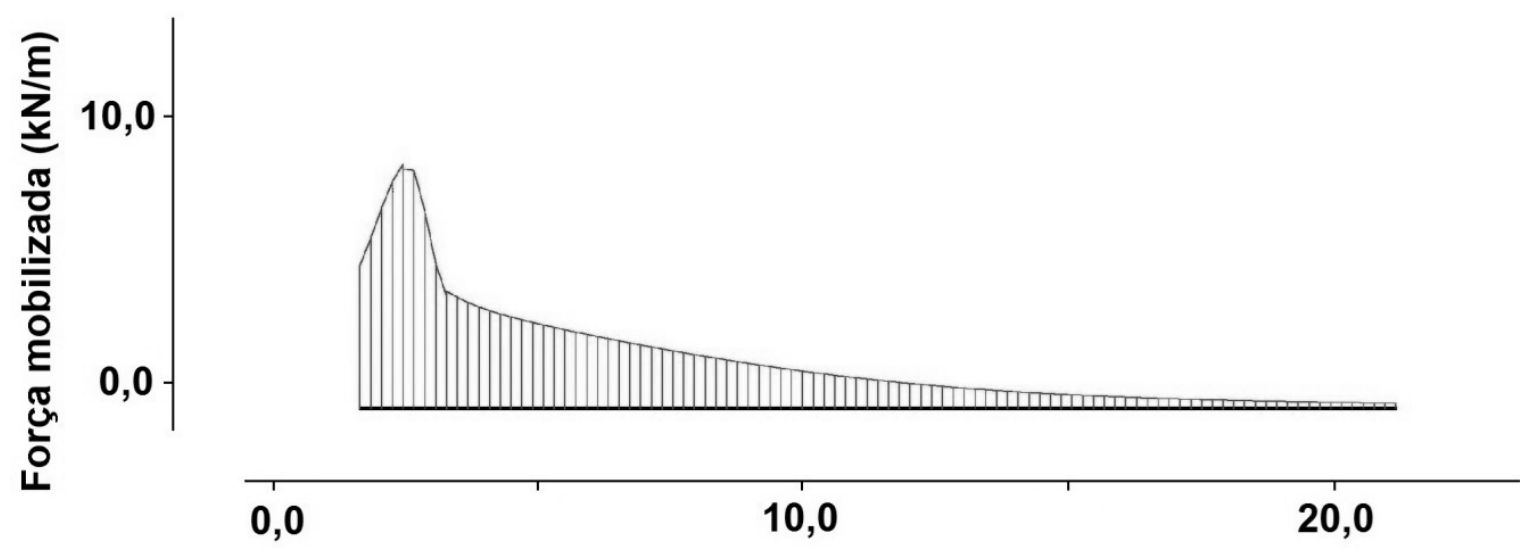

Distância horizontal (m)

Fonte: Próprio autor

A Figura 5.3 e a Figura 5.4 mostram respectivamente os deslocamentos horizontais máximos na face do muro e força máxima mobilizada no reforço mais solicitado para o MSRG construído com solos tropicais, inclinação de face $1 \mathrm{~V}: 3 \mathrm{H}$, reforço a cada 30 centímetros e rigidez do reforço de $11 \mathrm{kN} / \mathrm{m}$. Estão apresentados os resultados até a ruptura do muro ou até $20 \mathrm{~m}$ de altura, que foi o máximo valor simulado. Na prática, porém, utilizam-se geogrelhas (mais rígidas) para MSRG de grande altura. 
Figura 5.3 - Deslocamento horizontal máximo na face do MSRG construído com solos tropicais e reforço de $11 \mathrm{kN} / \mathrm{m}$

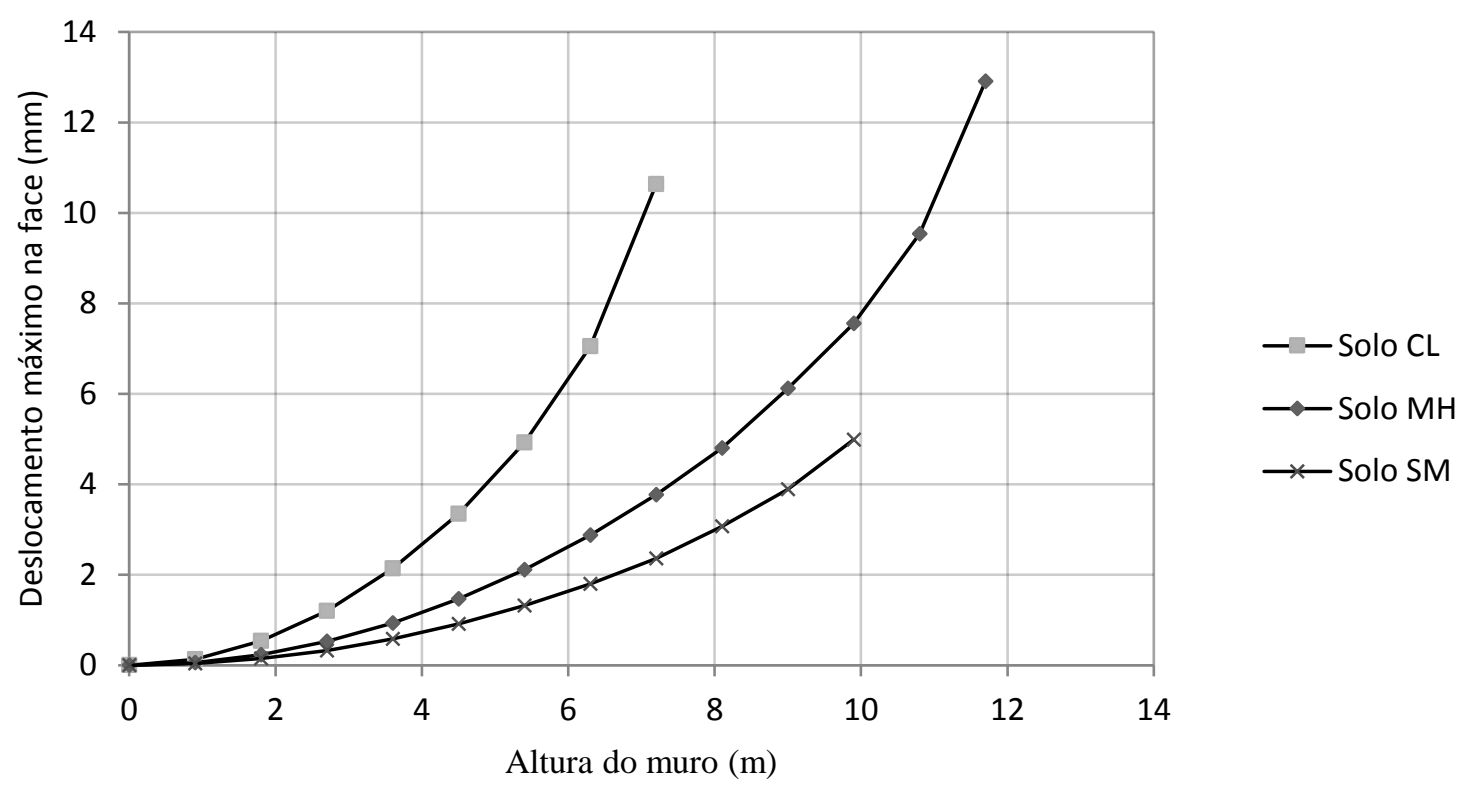

Fonte: Próprio autor

Figura 5.4 - Força máxima mobilizada no reforço do MSRG construído com solos tropicais e reforço de $11 \mathrm{kN} / \mathrm{m}$

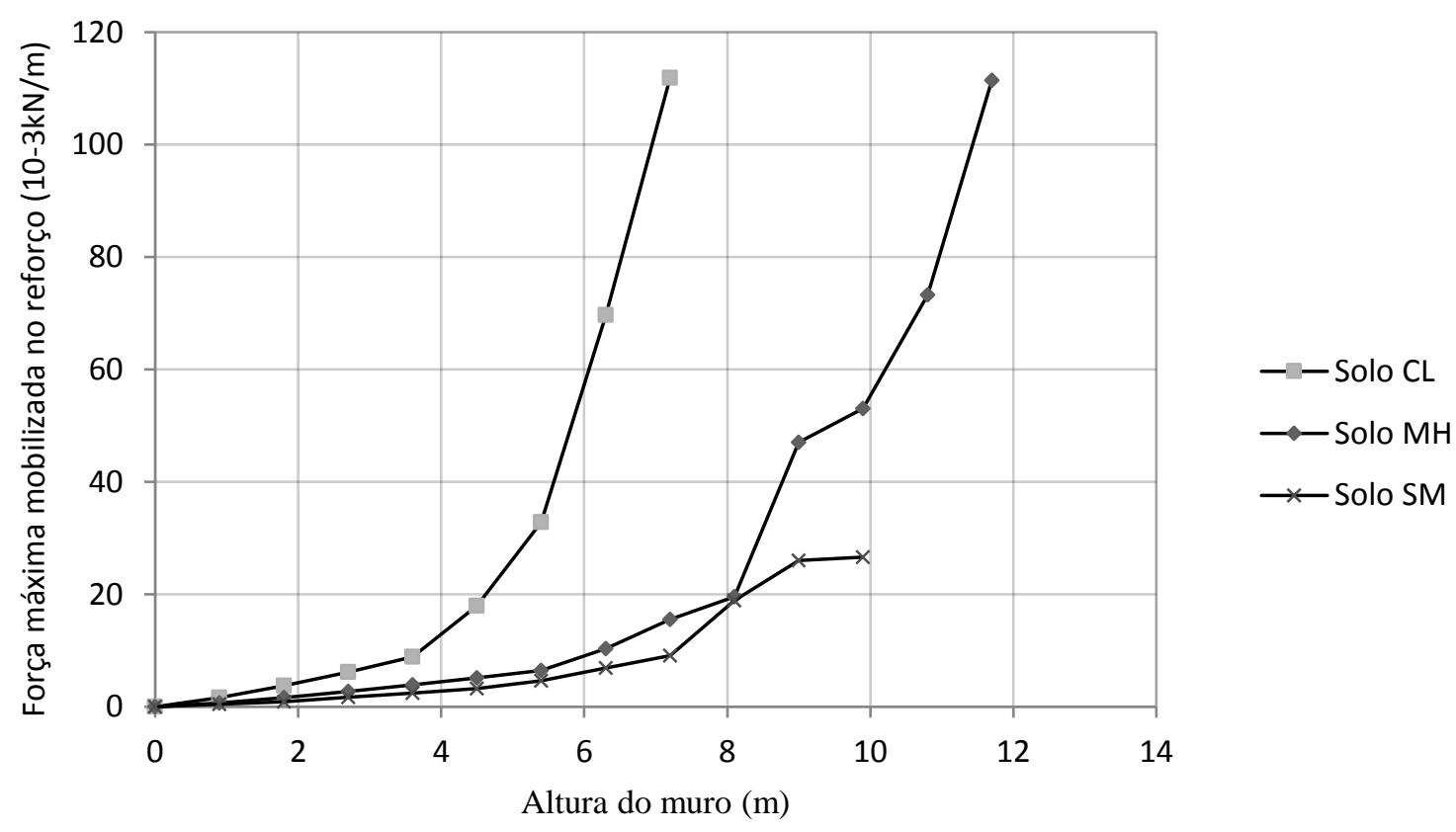

Fonte: Próprio autor 
Foi possível observar que ao se utilizar um reforço com rigidez de $11 \mathrm{kN} / \mathrm{m}$ (típica de um geotêxtil não tecido), o solo $\mathrm{CL}$ apresentou os maiores deslocamentos de face e solicitação do reforço. $\mathrm{O}$ muro romperia com a altura de $7 \mathrm{~m}$ para o solo $\mathrm{CL}, 10 \mathrm{~m}$ para o solo SM e $12 \mathrm{~m}$ para o solo $\mathrm{MH}$. Por outro lado, para muros de 10 $\mathrm{m}$ de altura, o deslocamento da face seria maior com o solo $\mathrm{MH}(\sim 8 \mathrm{~mm})$ do que com o solo SM ( $5 \mathrm{~mm})$.

A Figura 5.5 e a Figura 5.6 mostram respectivamente os deslocamentos horizontais máximos e força mobilizada no reforço para o MSRG construído com solos tropicais, inclinação de face $1 \mathrm{~V}: 3 \mathrm{H}$, reforço a cada 30 centímetros e rigidez do reforço de $100 \mathrm{kN} / \mathrm{m}$.

Figura 5.5 - Deslocamento horizontal máximo na face do MSRG construído com solos tropicais e reforço de $100 \mathrm{kN} / \mathrm{m}$

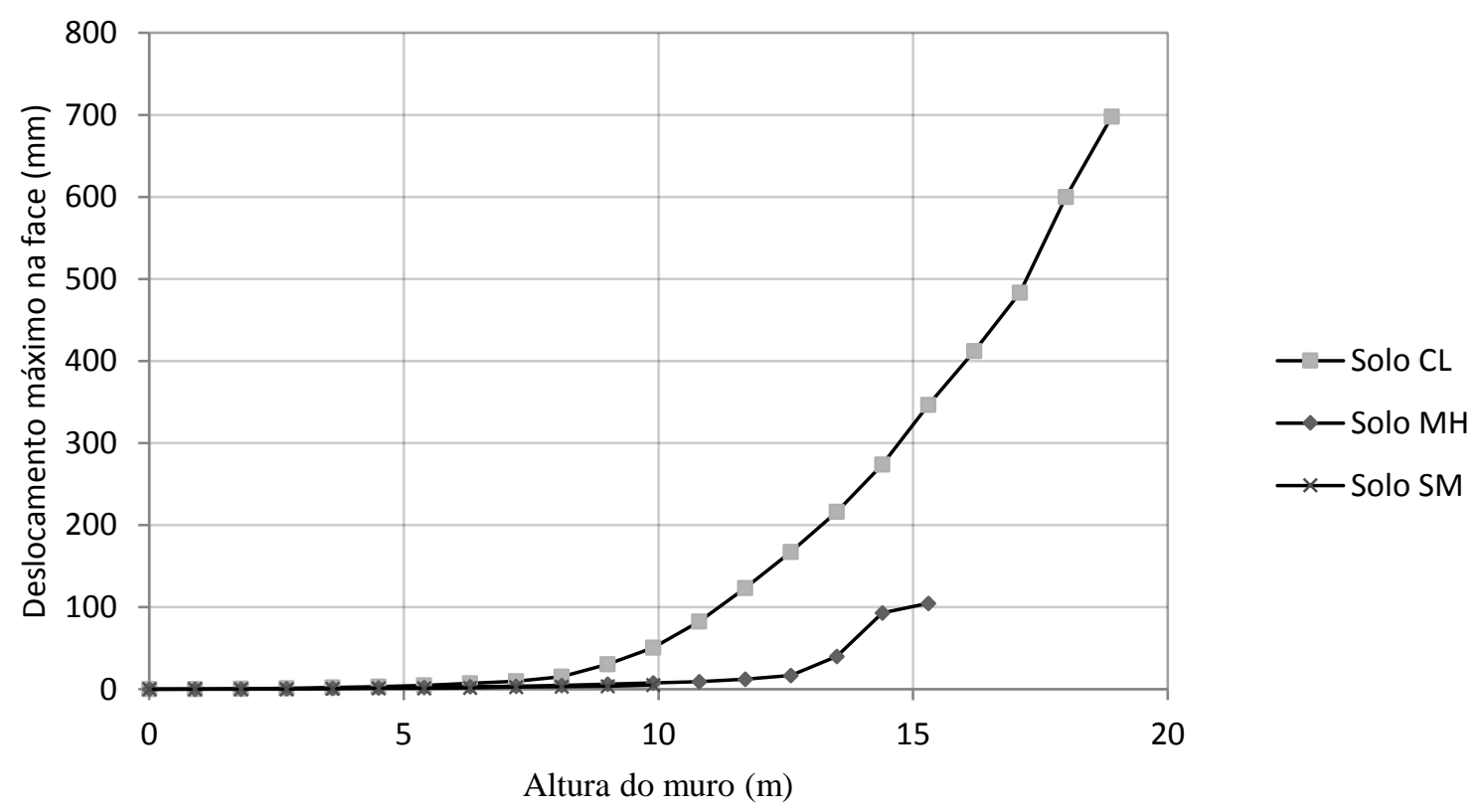

Fonte: Próprio autor 
Figura 5.6 - Força máxima mobilizada no reforço do MSRG construído com solos tropicais e reforço de $100 \mathrm{kN} / \mathrm{m}$

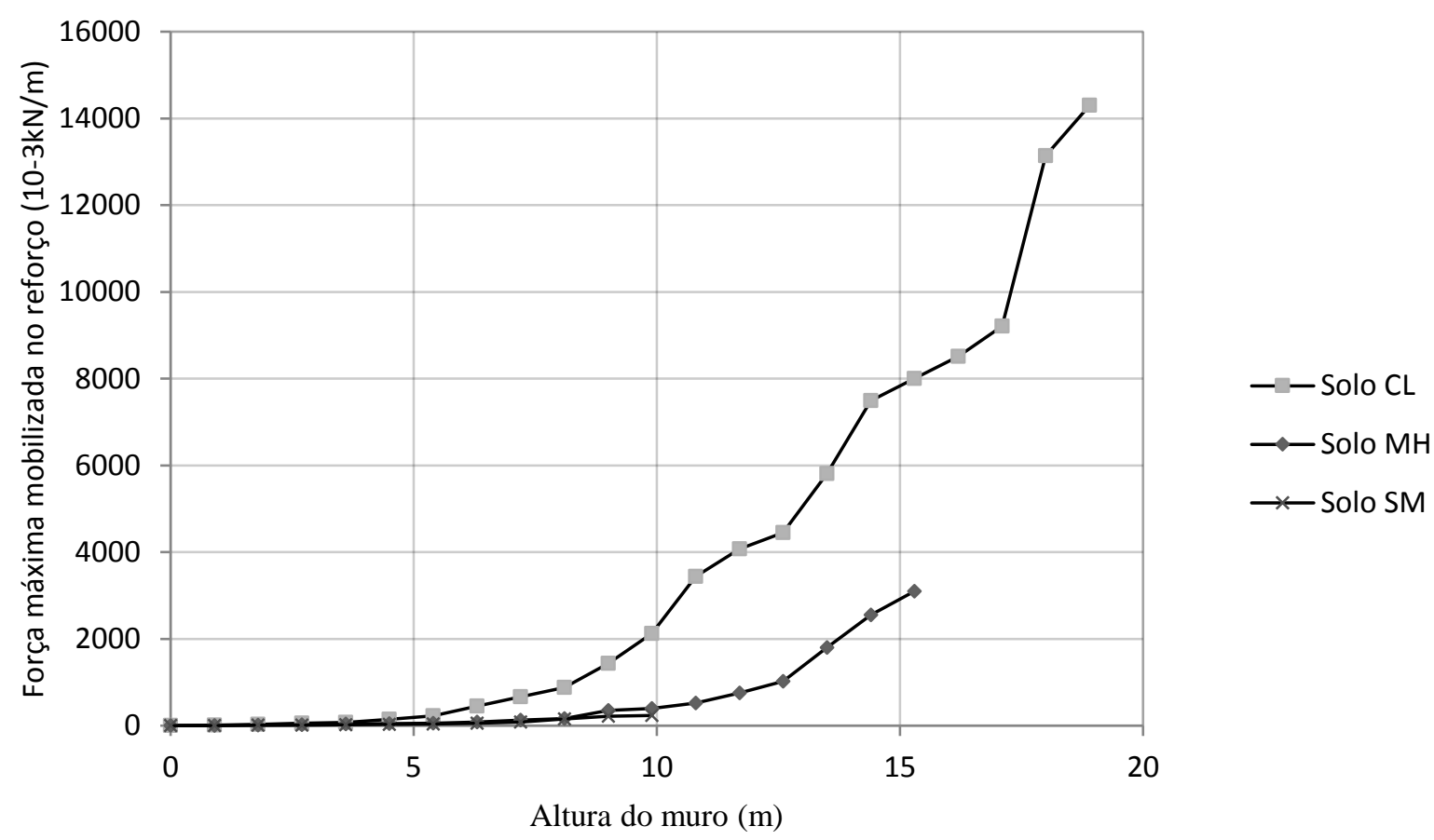

Fonte: Próprio autor

Foi possível observar que ao se utilizar um reforço com rigidez de $100 \mathrm{kN} / \mathrm{m}$ (típica de um geotêxtil tecido ou geogrelha) o solo CL apresentou os maiores deslocamentos de face e solicitação do reforço, e também atingiu a maior altura, 19 m. O muro romperia com a altura de $10 \mathrm{~m}$ para o solo SM e $16 \mathrm{~m}$ para o solo $\mathrm{MH}$.

A Figura 5.7 e a Figura 5.8 mostram respectivamente os deslocamentos horizontais máximos e força mobilizada no reforço para o MSRG construído com solos tropicais, inclinação de face $1 \mathrm{~V}: 3 \mathrm{H}$, reforço a cada 30 centímetros e rigidez do reforço de $500 \mathrm{kN} / \mathrm{m}$. 
Figura 5.7 - Deslocamento horizontal máximo na face do MSRG construído com solos tropicais e reforço de $500 \mathrm{kN} / \mathrm{m}$

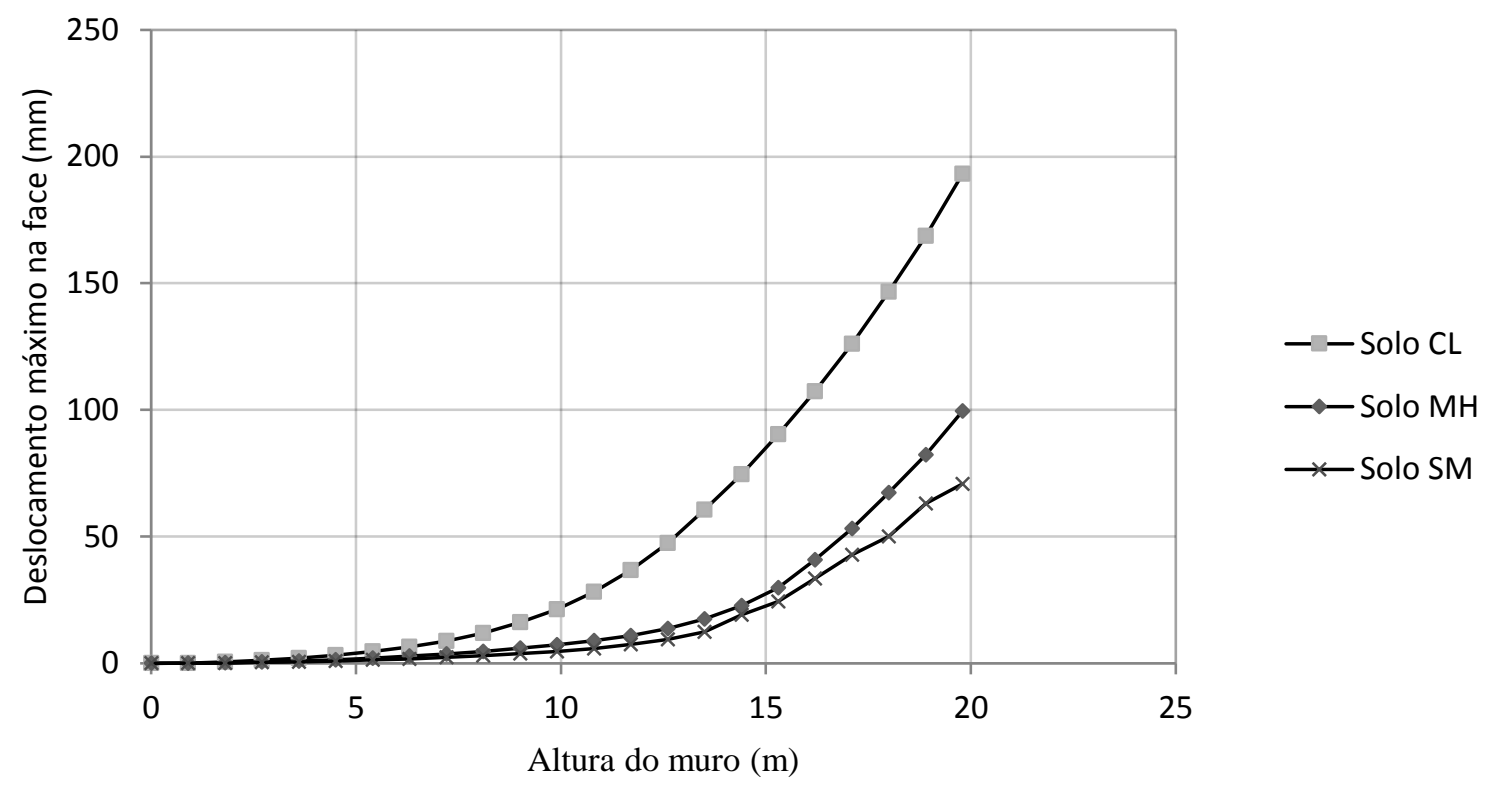

Fonte: Próprio autor

Figura 5.8 - Força máxima mobilizada no reforço do MSRG construído com solos tropicais e reforço de $500 \mathrm{kN} / \mathrm{m}$

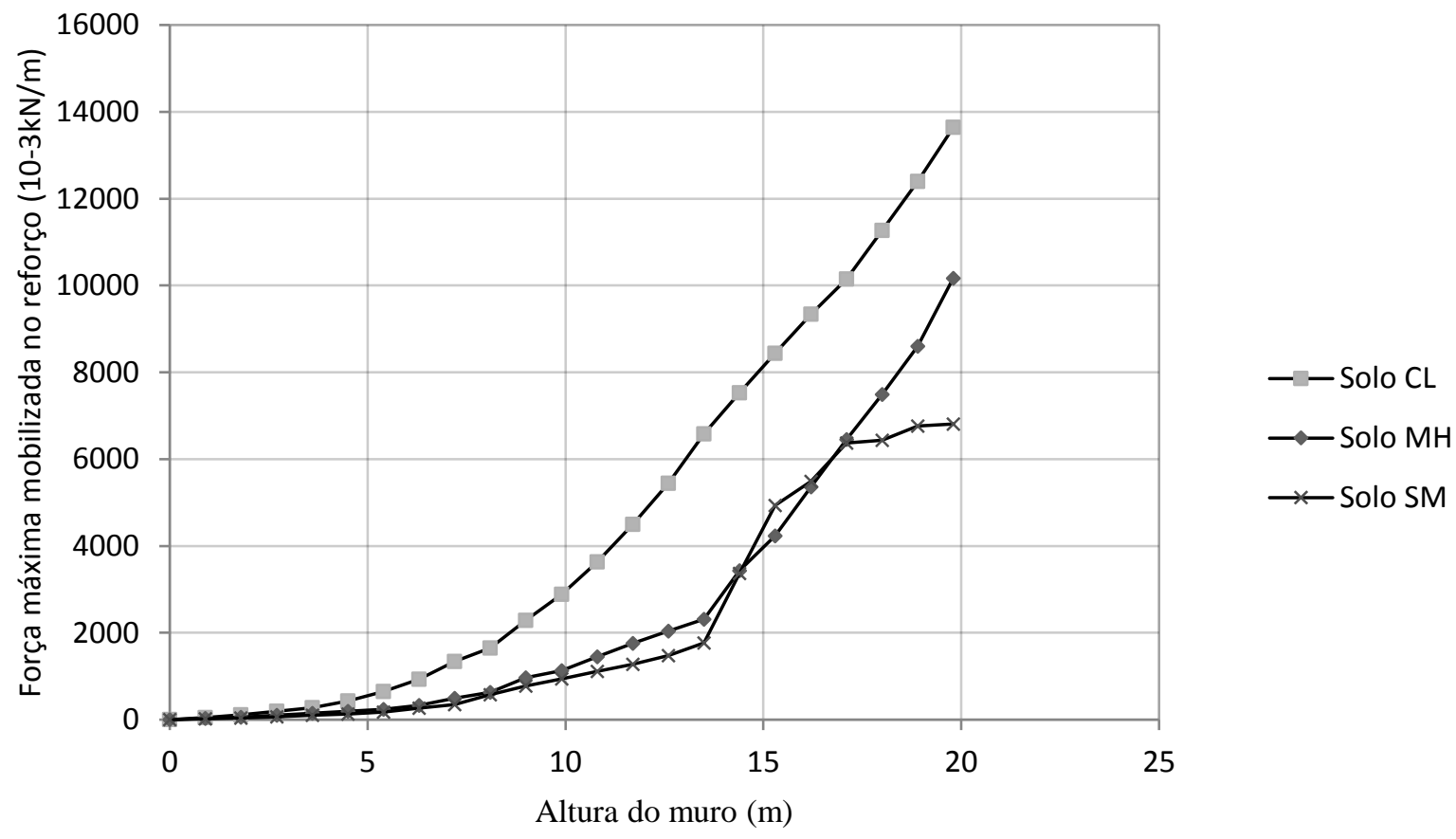

Fonte: Próprio autor 
Foi possível observar que ao se utilizar um reforço com rigidez de $500 \mathrm{kN} / \mathrm{m}$ (típica de uma geogrelha), o muro se manteria estável com $20 \mathrm{~m}$ de atura para qualquer dos três solos investigados. $\mathrm{O}$ solo $\mathrm{CL}$ apresentou os maiores deslocamentos de face e solicitação do reforço.

É interessante notar que para reforço com rigidez de $11 \mathrm{kN} / \mathrm{m}$, o muro atingiria maior altura com o solo $\mathrm{MH}$, enquanto que com rigidez de $100 \mathrm{kN} / \mathrm{m}$, a maior altura seria atingida com o solo $\mathrm{CL}$. Os deslocamentos máximos da face do muro são praticamente iguais para muros de mesma altura construídos com os solos MH e SM para qualquer reforço estudado; porém, comparando-se esses dois solos para o mesmo reforço, com o solo $\mathrm{MH}$ pode ser atingida maior altura.

A Figura 5.9 mostra a variação da potencial superfície de ruptura ao se variar o tipo de solo e a altura do MSRG com a rigidez do reforço de $100 \mathrm{kN} / \mathrm{m}$. Foram selecionadas algumas combinações que apresentaram valores extremos de deslocamento de face.

Figura 5.9 - Influência do tipo de solo na potencial superfície de ruptura do MSRG com reforço de $100 \mathrm{kN} / \mathrm{m}$

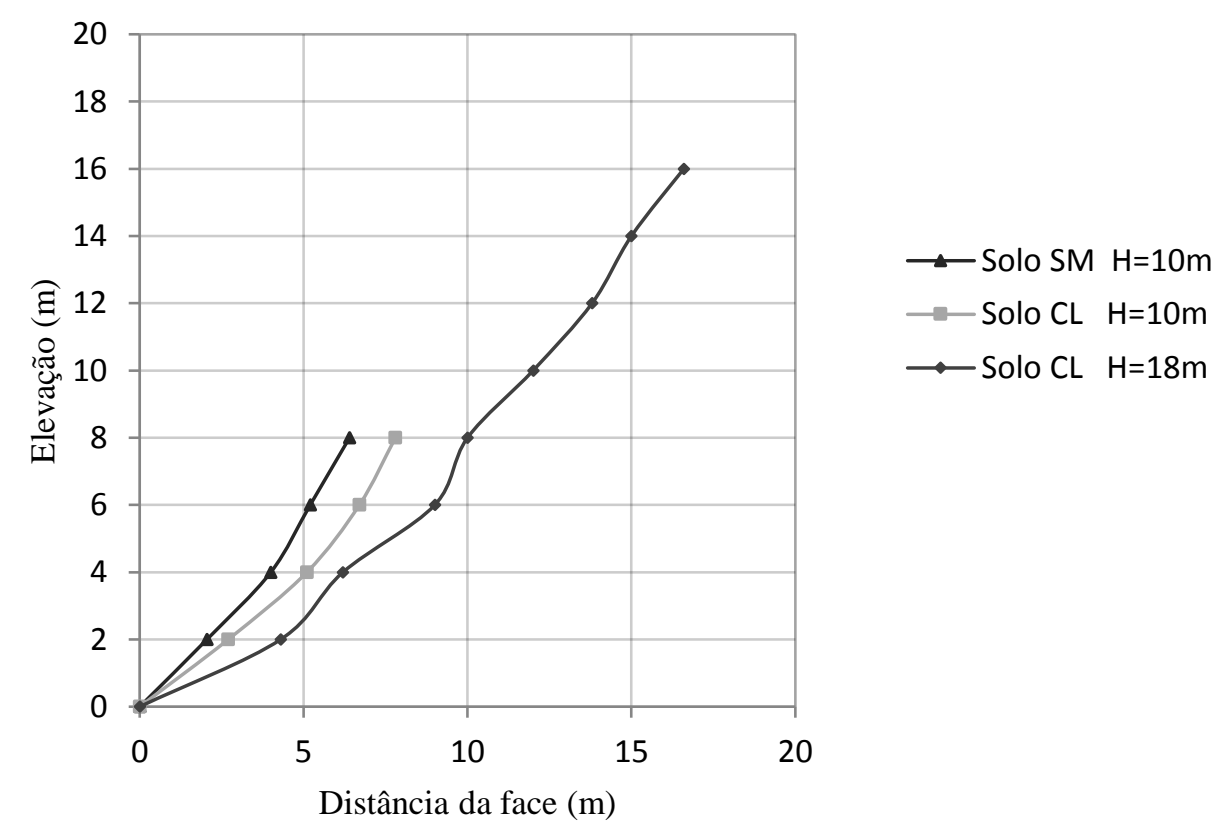


A análise da influência do tipo de solo na potencial superfície de ruptura é complexa, pois adotou-se o lugar geométrico dos pontos de maior deformação em cada reforço. Porém, para a altura de $10 \mathrm{~m}$, o muro construído com o solo SM está próximo da ruptura, enquanto o muro construído com o solo $\mathrm{CL}$ estaria em condição de trabalho.

Por outro, comparando-se as duas curvas para o solo $\mathrm{CL}$, o muro com $10 \mathrm{~m}$ de altura estaria na condição de trabalho e o muro com $18 \mathrm{~m}$ de altura estaria na condição de ruptura. Neste caso, para um dado solo, quanto mais alto o muro e mais próxima a situação de ruptura, menos inclinada é a potencial superfície de ruptura.

\subsection{SIMULAÇÕES DE MSRG COM ALTEAMENTO SUCESSIVO COM SOLOS HIPOTÉTICOS}

O estudo da influência da coesão é mostrado na Figura 5.10 e na Figura 5.11, que relacionam a altura do muro construído com o deslocamento máximo na face e a força máxima mobilizada no reforço. Foram fixados os seguintes parâmetros: rigidez do geossintético $(\mathrm{J}=11 \mathrm{kN} / \mathrm{m})$; altura máxima simulada $(\mathrm{H}=5 \mathrm{~m})$; comprimento do reforço $(L=5 \mathrm{~m})$, e ângulo de atrito e módulo de rigidez do solo $\left(\varphi=20^{\circ}\right.$ e $\left.E=10 \mathrm{MPa}\right)$. 
Figura 5.10 - Influência da coesão no deslocamento horizontal em MSRG

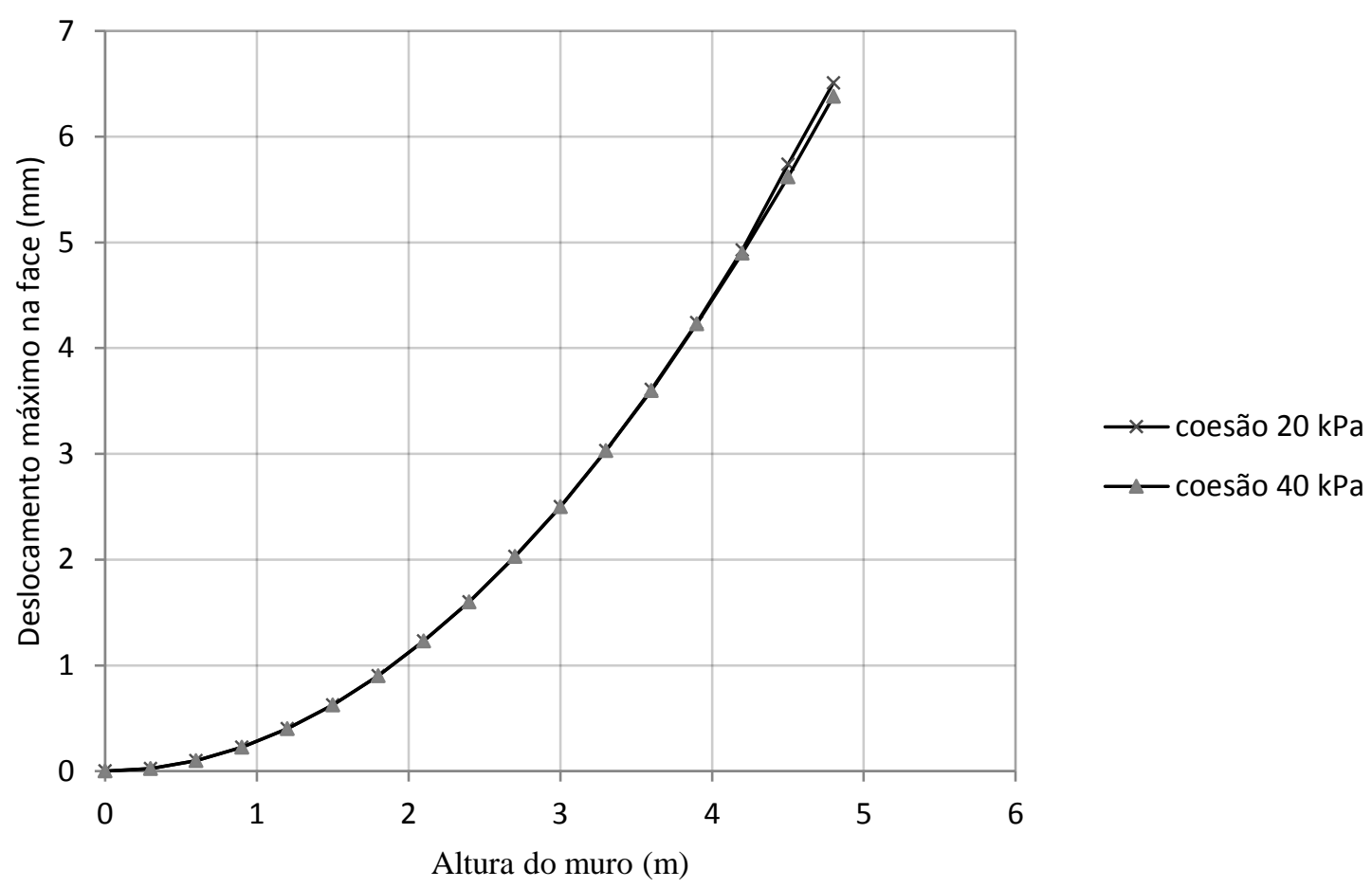

Fonte: Próprio autor

Figura 5.11 - Influência da coesão na mobilização do reforço em MSRG

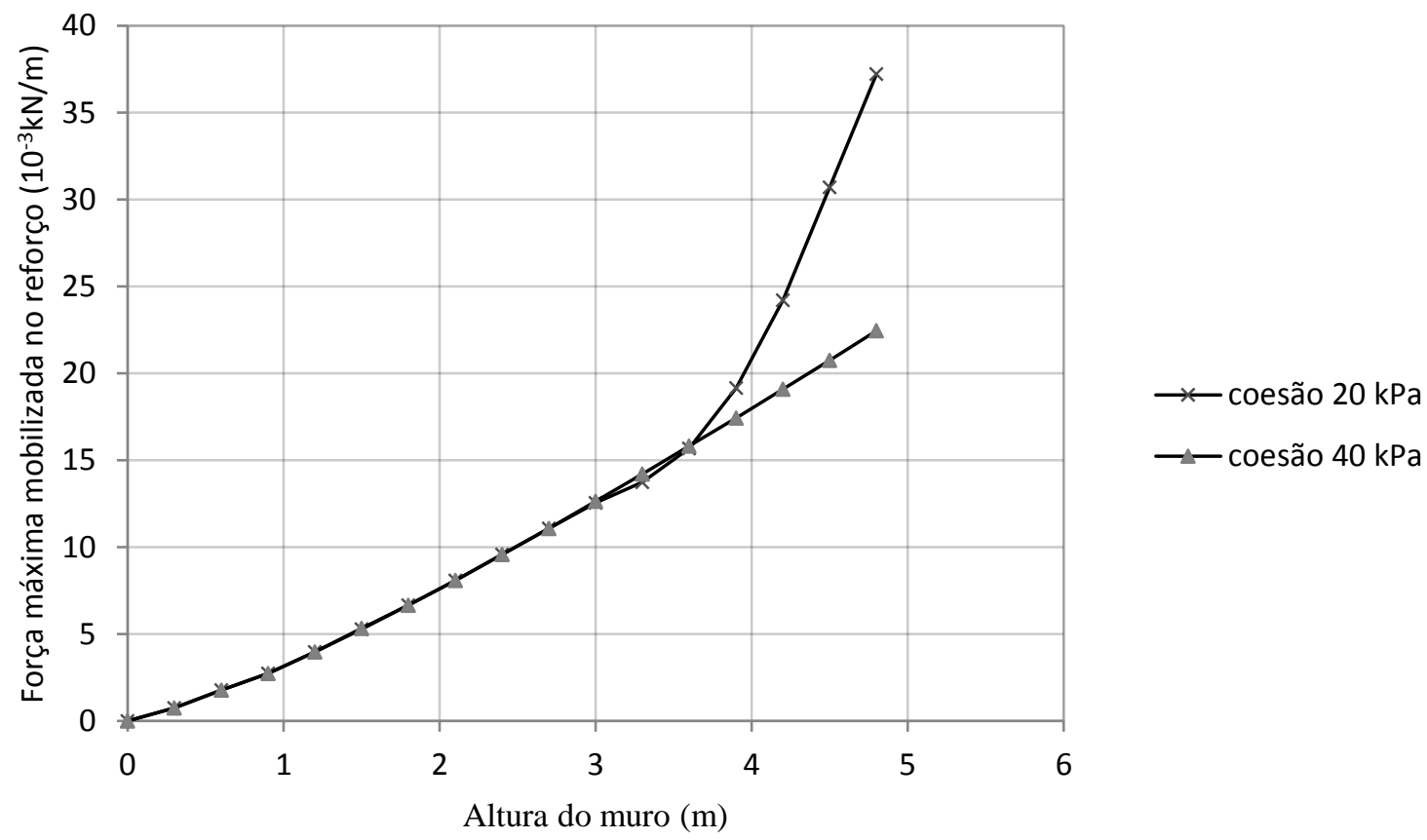

Fonte: Próprio autor 
Observa-se que enquanto o muro pode atingir 4,8 m com coesão de 20 ou 40 $\mathrm{kPa}$. Foi observado também que nas simulações com coesão de 20 e $40 \mathrm{kPa}$ os deslocamentos do MSRG se mantiveram praticamente idênticas.

A influência da rigidez do solo é mostrada na Figura 5.12 e na Figura 5.13, que relacionam a altura do muro construído com o deslocamento máximo na face e a força máxima mobilizada no reforço. Foram fixados os seguintes parâmetros: rigidez do geossintético $(\mathrm{J}=11 \mathrm{kN} / \mathrm{m})$; altura máxima simulada $(\mathrm{H}=5 \mathrm{~m})$; comprimento do reforço $(L=5 \mathrm{~m})$, e coesão e ângulo de atrito do solo ( $\mathrm{c}=20 \mathrm{kPa}$ e $\left.\varphi=20^{\circ}\right)$.

Figura 5.12 - Influência da rigidez do solo no deslocamento horizontal em MSRG

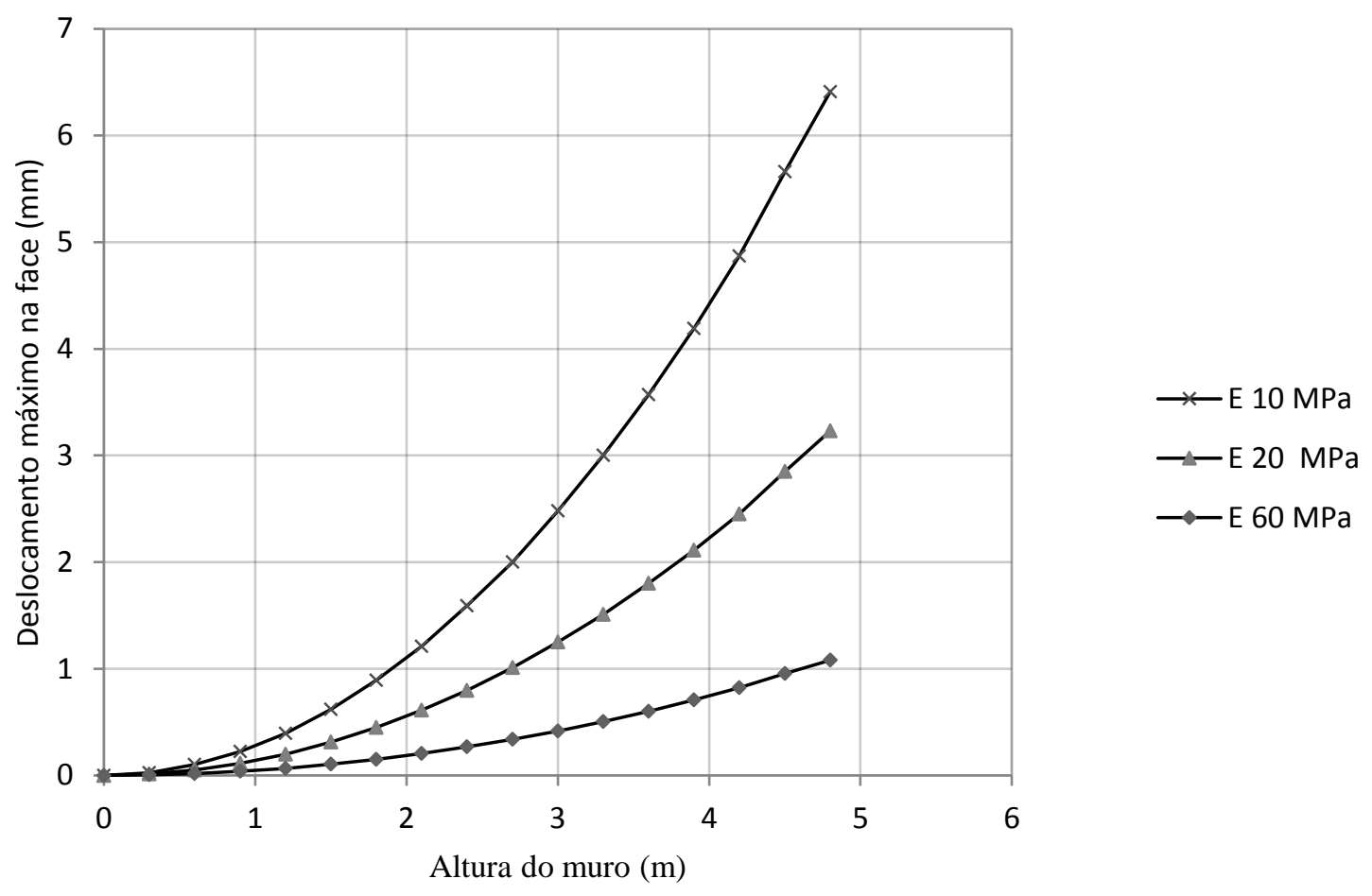

Fonte: Próprio autor 
Figura 5.13 - Influência da rigidez do solo na mobilização do reforço em MSRG

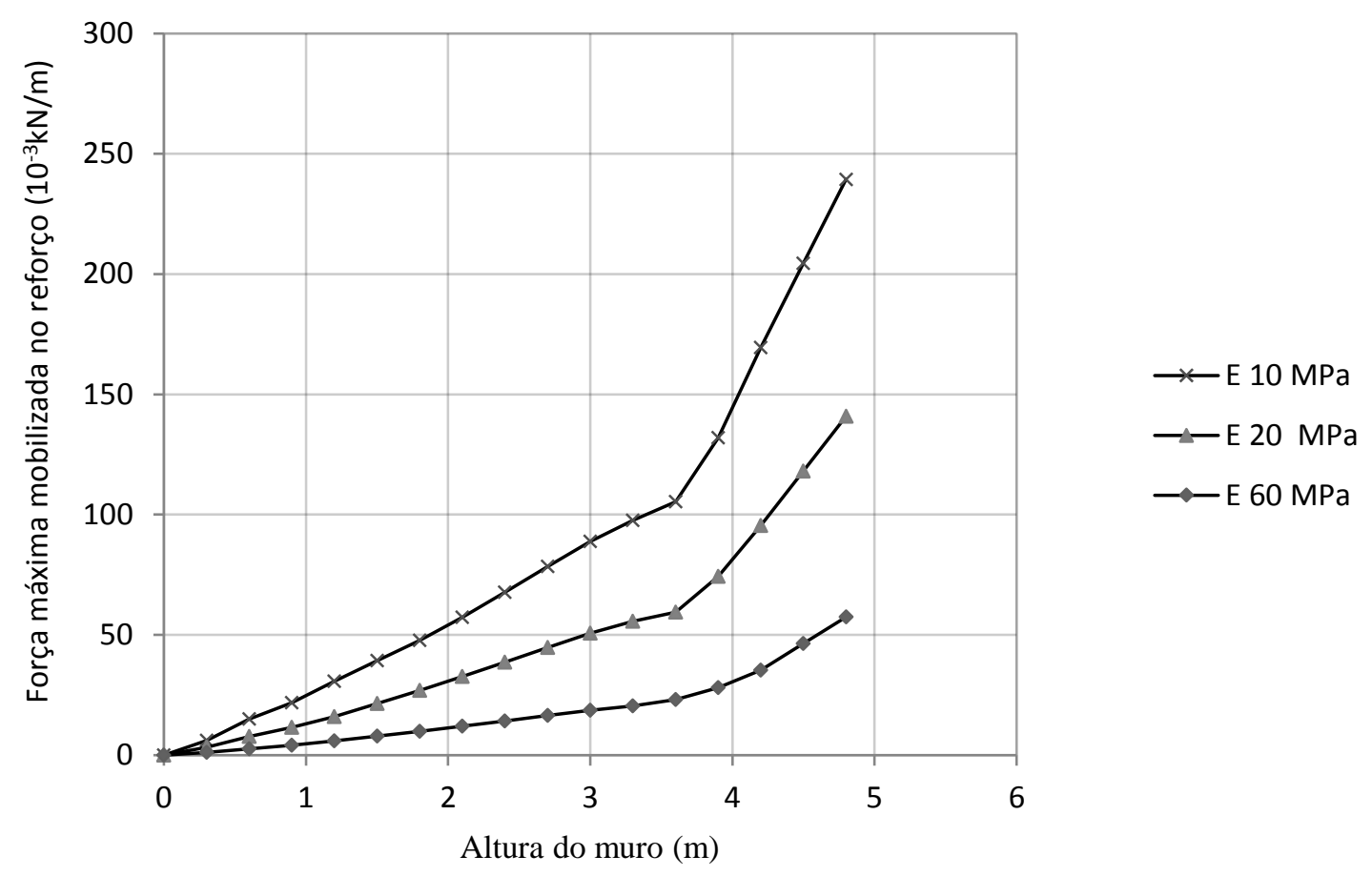

Fonte: Próprio autor

Para as condições estudadas, o módulo de rigidez do solo e o deslocamento máximo estão inversamente relacionados, sendo que ao se dobrar a rigidez do solo observou-se metade do deslocamento máximo.

O estudo da influência do comprimento do reforço é mostrado na Figura 5.14 e na Figura 5.15, que relacionam a altura do muro construído com o deslocamento máximo na face e a força máxima mobilizada no reforço. Foram fixados os seguintes parâmetros: rigidez do geossintético $(\mathrm{J}=11 \mathrm{kN} / \mathrm{m})$; e coesão, ângulo de atrito e módulo de rigidez do solo ( $\mathrm{c}=20 \mathrm{kPa}, \varphi=20^{\circ}$ e $\mathrm{E}=10 \mathrm{MPa}$ ). Foram testadas duas condições: comprimento do reforço de $5 \mathrm{~m}(\mathrm{~L}=5 \mathrm{~m})$ com alteamento sucessivo até 5 $\mathrm{m}(\mathrm{H}=5 \mathrm{~m})$, e comprimento de reforço de $10 \mathrm{~m}(\mathrm{~L}=10 \mathrm{~m})$ com alteamento sucessivo até $10 \mathrm{~m}(\mathrm{H}=10 \mathrm{~m})$. 
Figura 5.14 - Influência do comprimento do reforço no deslocamento horizontal em MSRG

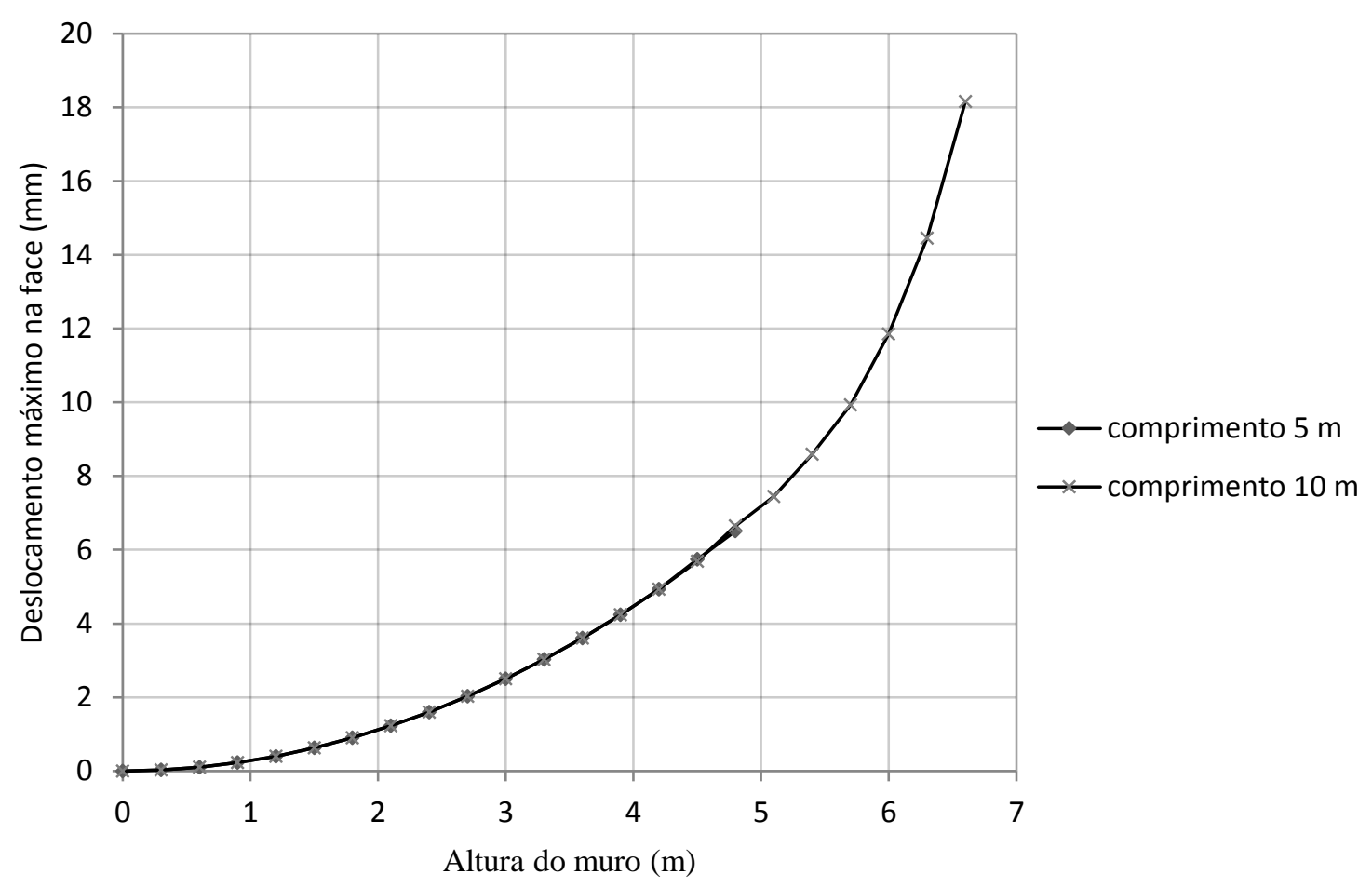

Fonte: Próprio autor

Figura 5.15 - Influência do comprimento do reforço na mobilização do reforço em MSRG

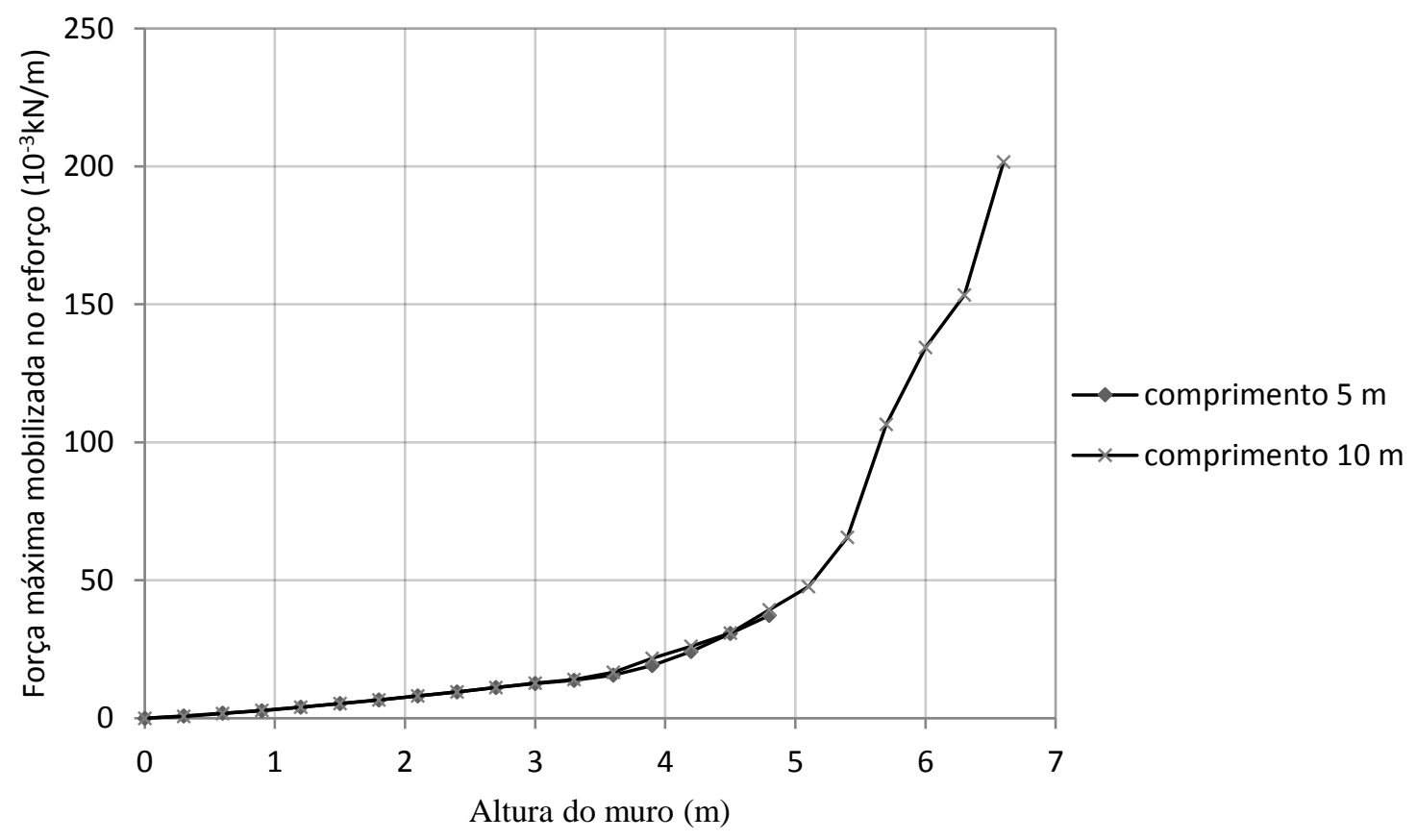

Fonte: Próprio autor 
Comparando-se os máximos deslocamentos na face dos muros alteados até $5 \mathrm{~m}$, conclui-se que o comprimento do reforço $(5 \mathrm{~m}$ ou $10 \mathrm{~m}$ ) não modificou $\mathrm{o}$ comportamento do muro. Este resultado era esperado, pois $5 \mathrm{~m}$ de comprimento de reforço já ultrapassam a superfície potencial de ruptura de um muro de $5 \mathrm{~m}$ de altura, garantindo a estabilidade externa do muro.

O estudo da influência da rigidez do reforço é mostrado na Figura 5.16 e na Figura 5.17, que relacionam a altura do muro construído com o deslocamento máximo na face e força máxima mobilizada no reforço. Foram fixados os seguintes parâmetros: altura máxima da simulação $(H=5 \mathrm{~m})$; comprimento do reforço $(\mathrm{L}=5 \mathrm{~m})$, e coesão, ângulo de atrito e módulo de rigidez do solo ( $\mathrm{c}=20 \mathrm{kPa} \varphi=20^{\circ}$ e $\mathrm{E}=60$ $\mathrm{MPa}$ ). Como para esses parâmetros do solo não se observou anteriormente diferença nos deslocamentos em função da rigidez do reforço, na simulação com $\mathrm{J}=500 \mathrm{kN} / \mathrm{m}$ utilizaram-se os seguintes parâmetros: $\mathrm{c}=40 \mathrm{kPa} ; \varphi=40^{\circ}$, e E=60 MPa.

Figura 5.16 - Influência da rigidez do reforço no deslocamento horizontal em MSRG

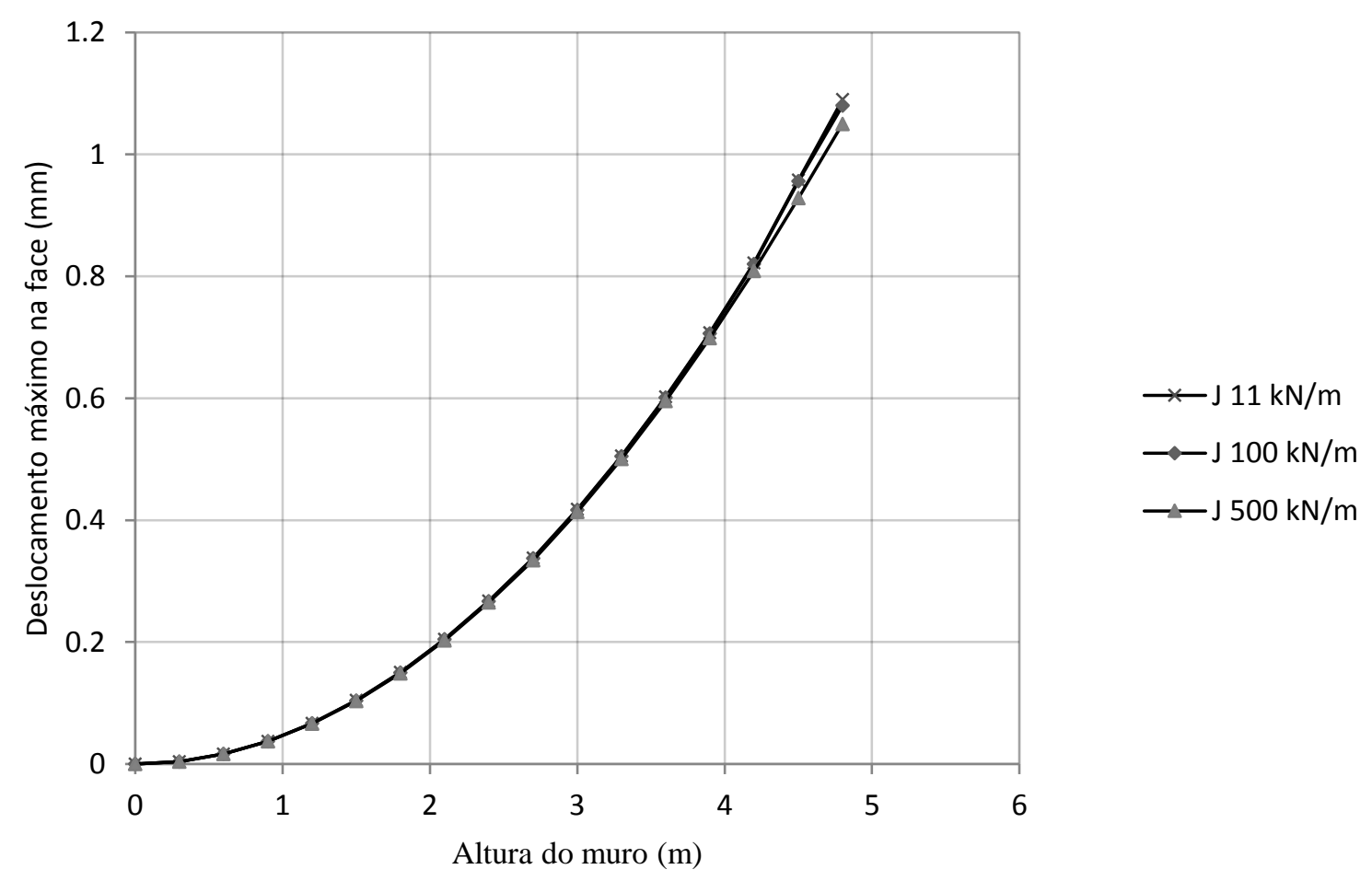

Fonte: Próprio autor 
Figura 5.17 - Influência da rigidez do reforço na mobilização do reforço em MSRG

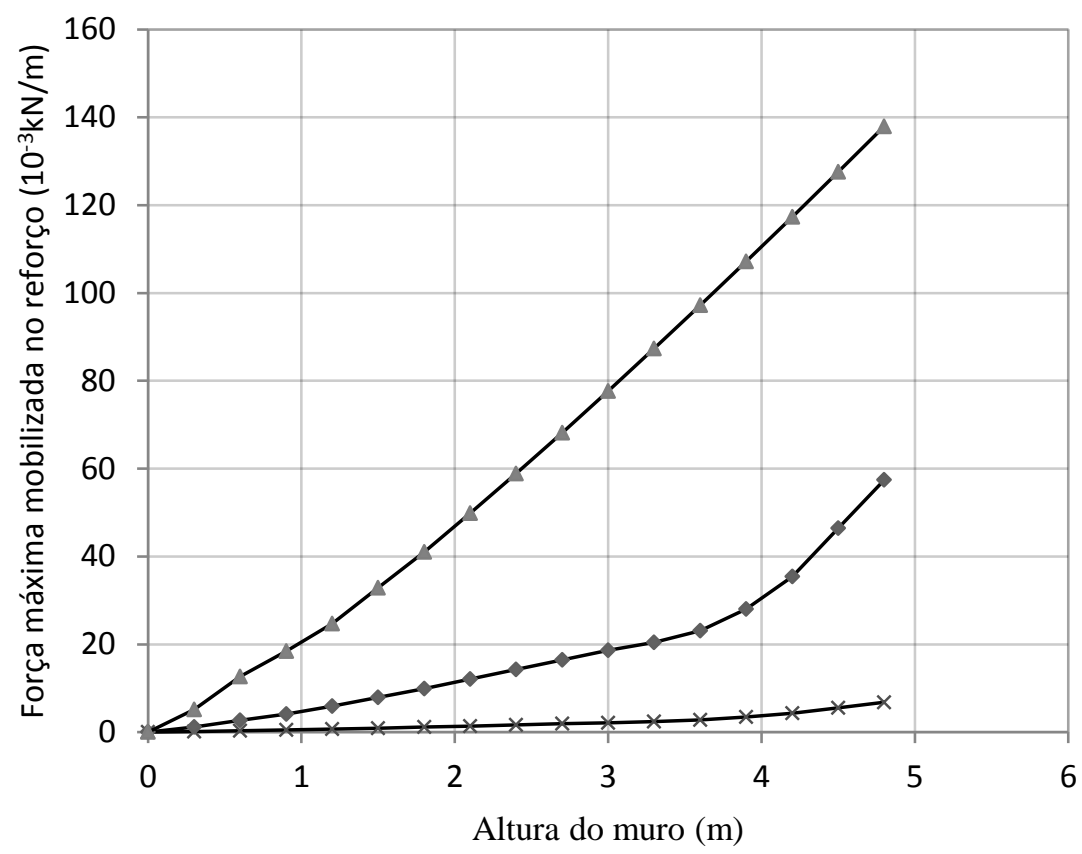

* J $11 \mathrm{kN} / \mathrm{m}$

$\rightarrow-\mathrm{J} 100 \mathrm{kN} / \mathrm{m}$

$\neg-\mathrm{J} 500 \mathrm{kN} / \mathrm{m}$

Fonte: Próprio autor

Observa-se uma discreta diferença nos deslocamentos horizontais da face com o aumento da rigidez do reforço apenas para alturas acima de $4 \mathrm{~m}$. Nos três casos a estrutura se manteve estável ao atingir $5 \mathrm{~m}$ de altura. Como ao aumentar os parâmetros de resistência do solo e rigidez do reforço a deformada da face não se alterou, pode-se concluir que MSRGs com a configuração estudada construídos com solo de elevada resistência tem sua deformada influenciada principalmente pelo módulo de rigidez do solo e não pela rigidez do reforço.

O comportamento das curvas de deslocamento e das forças mobilizadas em função dos diversos parâmetros apresentadas neste item foram muitos similares, com exceção do caso em que houve variação da rigidez do reforço (Figura 5.17).

\subsection{SIMULAÇÕES DE MSRG DE 10 M DE ALTURA COM VARIAÇÕES SISTEMÁTICAS DOS PARÂMETROS DO SOLO}

Os dados apresentados nesta parte foram extraídos das simulações identificadas com a sigla "PAR". Os dados foram ordenados de modo que se pudesse observar a variação no comportamento do MSRG ao se modificar o ângulo de atrito, coesão ou o módulo de elasticidade do solo. Foram fixados os seguintes parâmetros: rigidez do geossintético $(\mathrm{J}=1.000 \mathrm{kN} / \mathrm{m})$; espaçamento vertical do 
geossintético $(\mathrm{e}=30 \mathrm{~cm})$; altura do muro $(\mathrm{H}=10 \mathrm{~m})$; comprimento do reforço $(\mathrm{L}=8 \mathrm{~m})$; inclinação da face $(9 \mathrm{~V}: 1 \mathrm{H})$, e elemento Plate na face.

\subsubsection{Estudo da influência do ângulo de atrito do solo}

A Figura 5.18 e a Figura 5.19 mostram respectivamente os deslocamentos horizontais máximos na face e a força máxima mobilizada no reforço em função do ângulo de atrito do solo fixando a coesão (c=10 kPa).

Figura 5.18 - Influência do ângulo de atrito no deslocamento horizontal - coesão $10 \mathrm{kPa}$

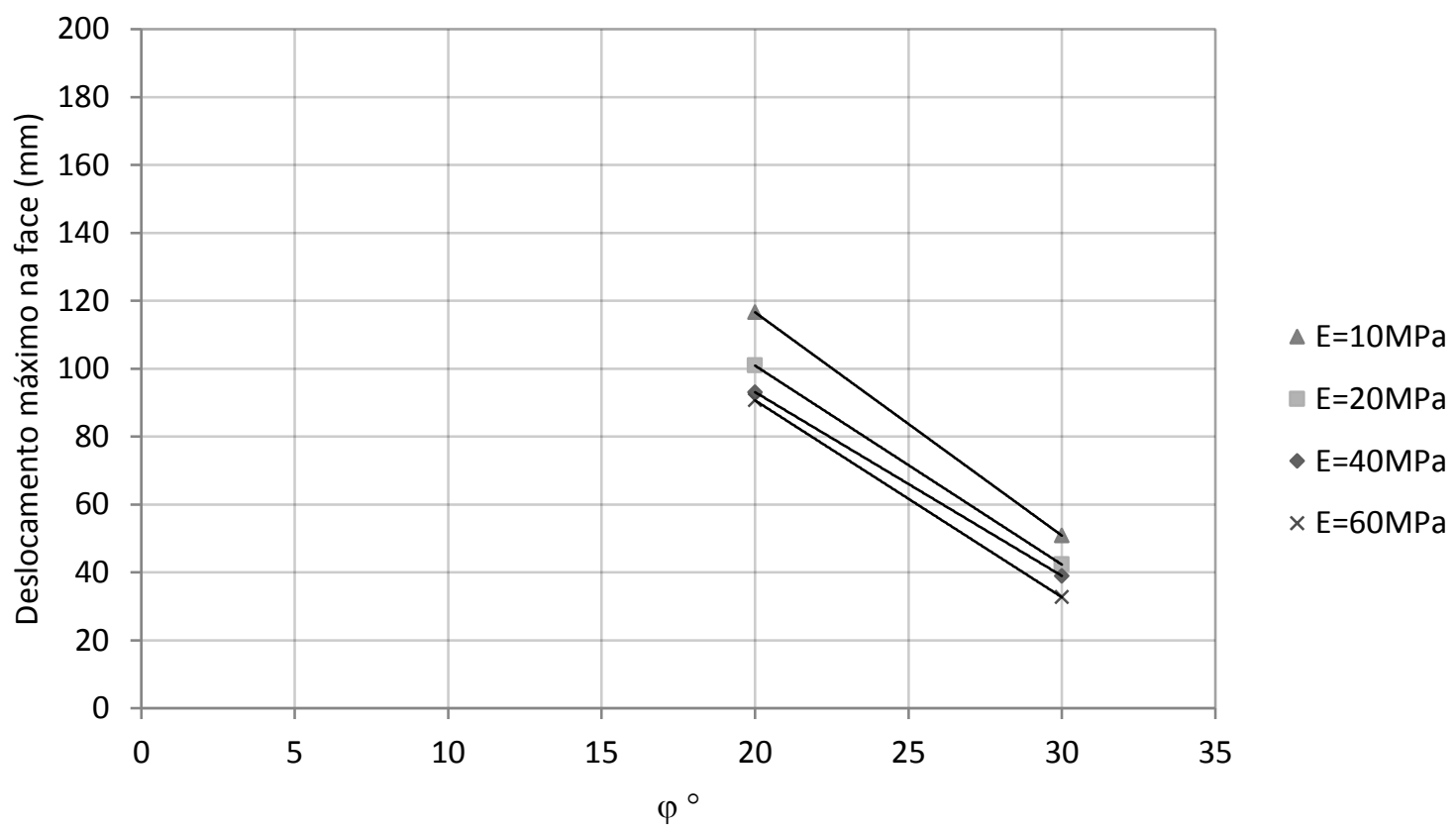

Fonte: Próprio autor 
Figura 5.19- Influência do ângulo de atrito na mobilização do reforço - coesão $10 \mathrm{kPa}$

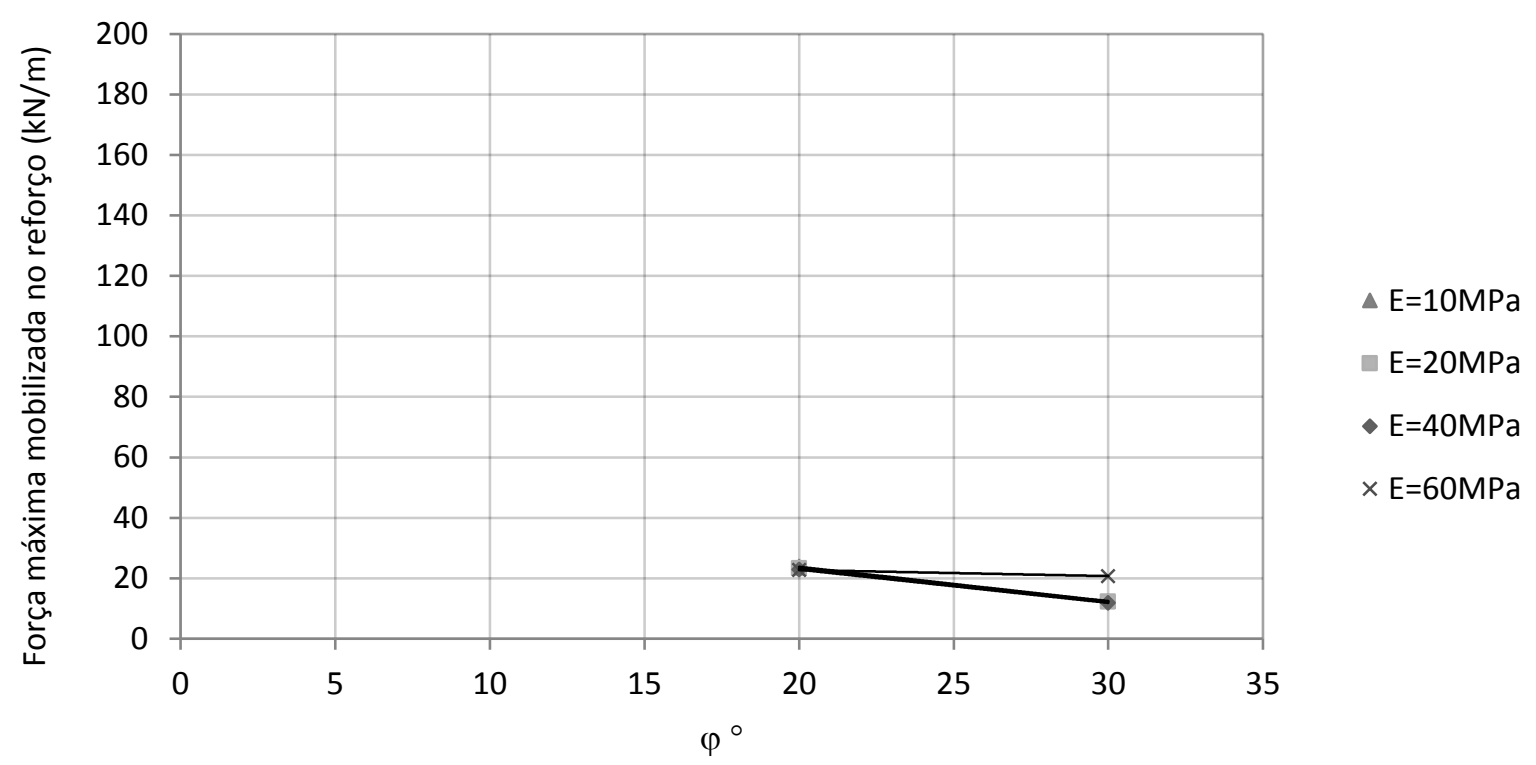

Fonte: Próprio autor

Houve o colapso da estrutura para o ângulo de atrito de $10^{\circ}$, nas demais simulações houve um decréscimo dos deslocamentos com 0 aumento da resistência. A influência do módulo de elasticidade do solo se manteve com o aumento da resistência ( $20 \mathrm{~mm}$ de diferença entre $\mathrm{E}=10 \mathrm{MPa}$ e E=60 MPa).

A Figura 5.20 e a Figura 5.21 mostram respectivamente os deslocamentos horizontais máximos na face e a força máxima mobilizada no reforço em função do ângulo de atrito do solo fixando a coesão (c=20 kPa). 
Figura 5.20 - Influência do ângulo de atrito no deslocamento horizontal - coesão $20 \mathrm{kPa}$

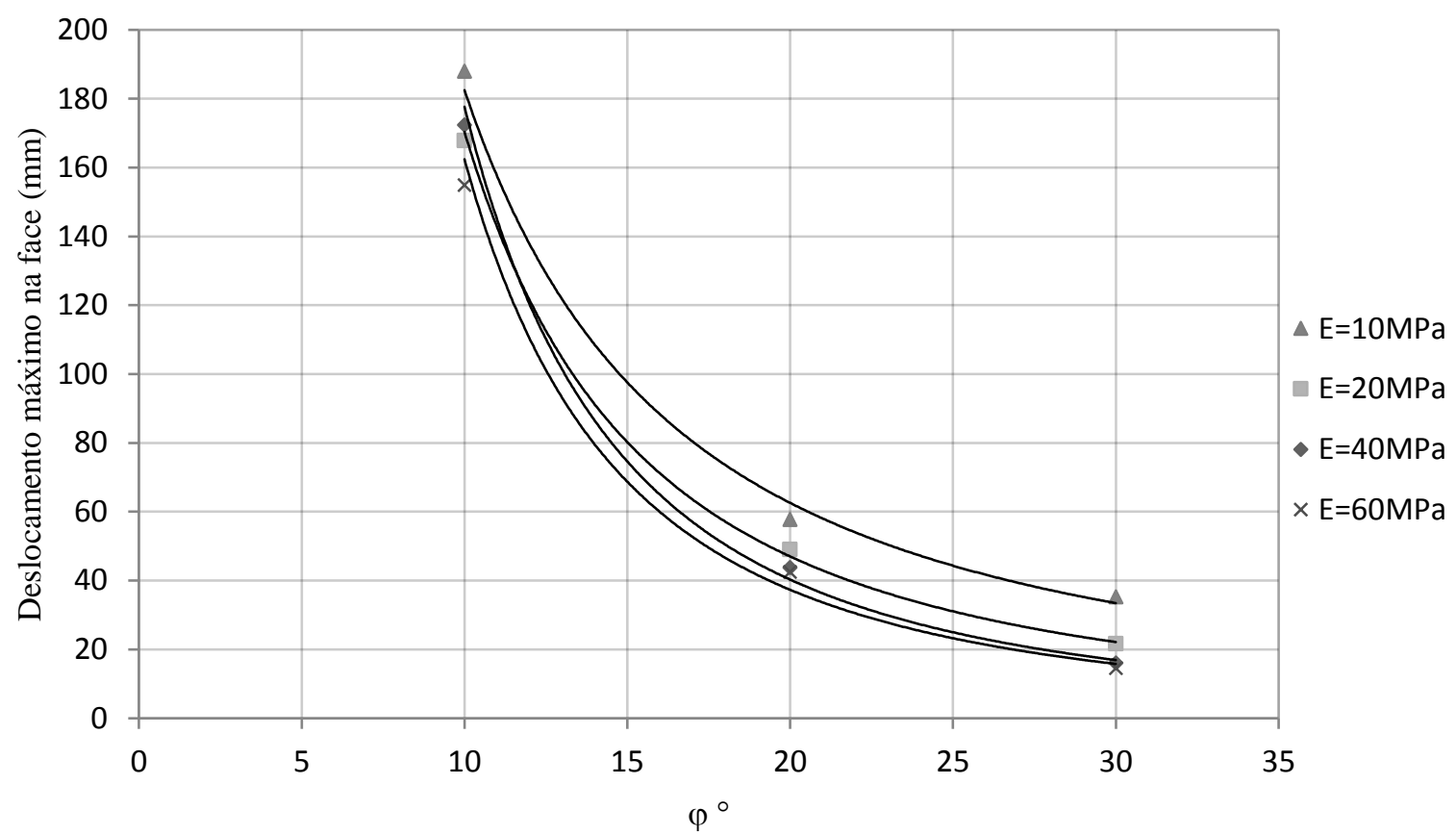

Fonte: Próprio autor

Figura 5.21- Influência do ângulo de atrito na mobilização do reforço - coesão $20 \mathrm{kPa}$

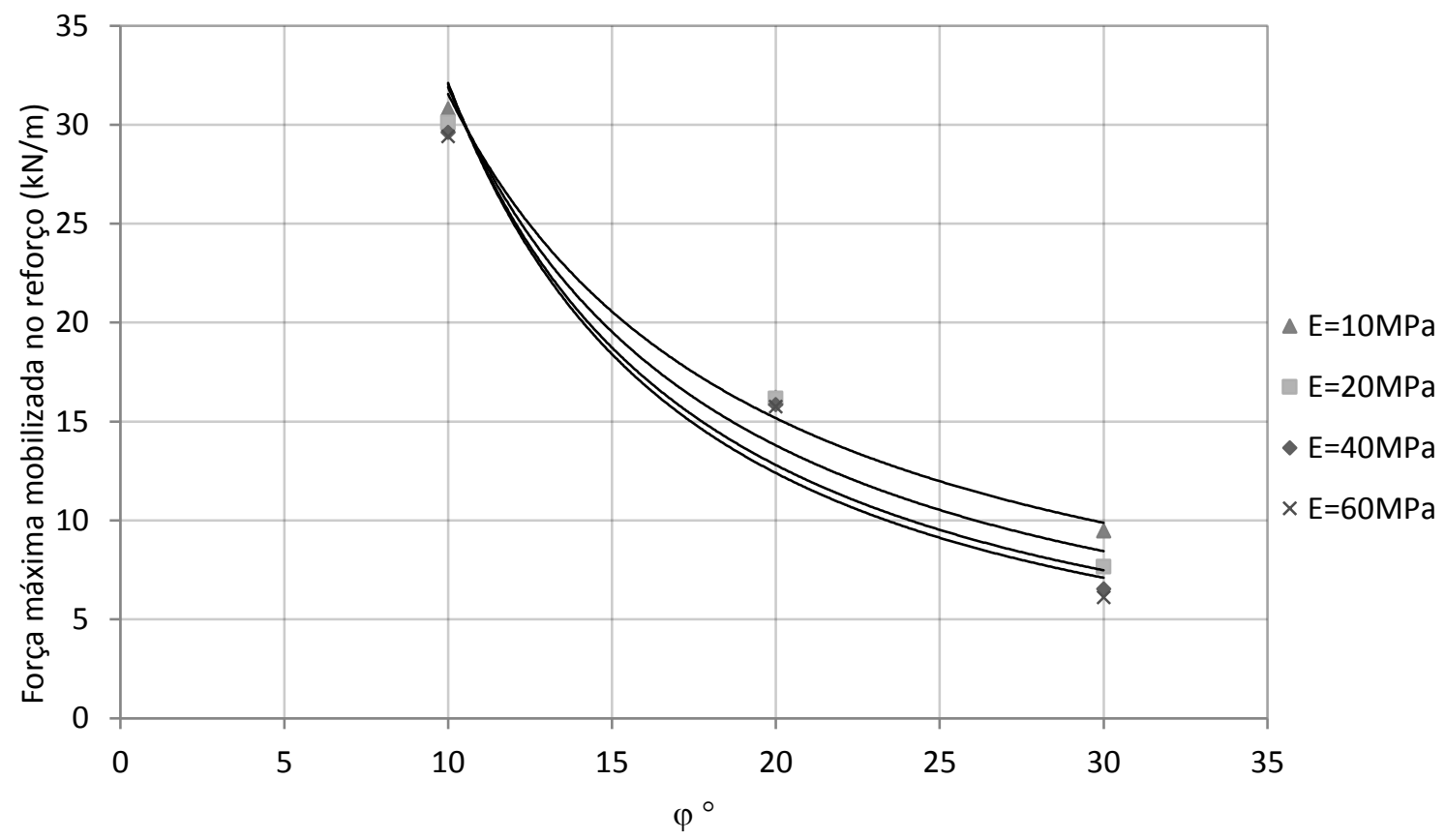

Fonte: Próprio autor 
Em todas as simulações o muro não rompeu com a altura de $10 \mathrm{~m}$. Na variação do ângulo de atrito de $10^{\circ}$ para $20^{\circ}$ a diminuição do deslocamento máximo na face (140 a $160 \mathrm{~mm}$ ) foi mais significativa do que de $20^{\circ}$ para $30^{\circ}(\sim 20 \mathrm{~mm})$.

A Figura 5.22 e a Figura 5.23 mostram respectivamente os deslocamentos horizontais máximos na face e a força máxima mobilizada no reforço em função do ângulo de atrito do solo fixando a coesão $(\mathrm{c}=40 \mathrm{kPa})$.

Figura 5.22 - Influência do ângulo de atrito no deslocamento horizontal - coesão $40 \mathrm{kPa}$

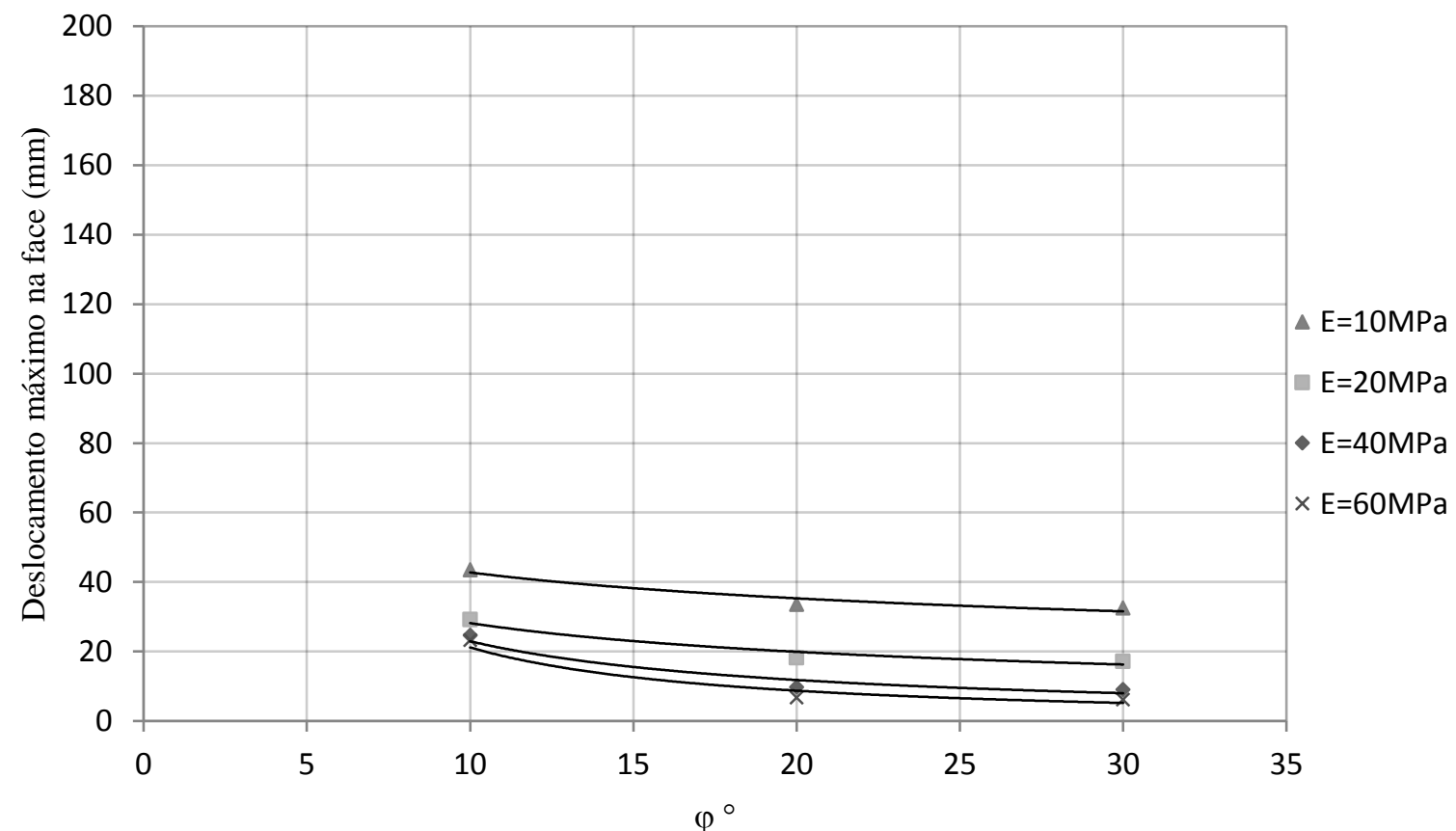

Fonte: Próprio autor 
Figura 5.23- Influência do ângulo de atrito na mobilização do reforço - coesão 40 kPa

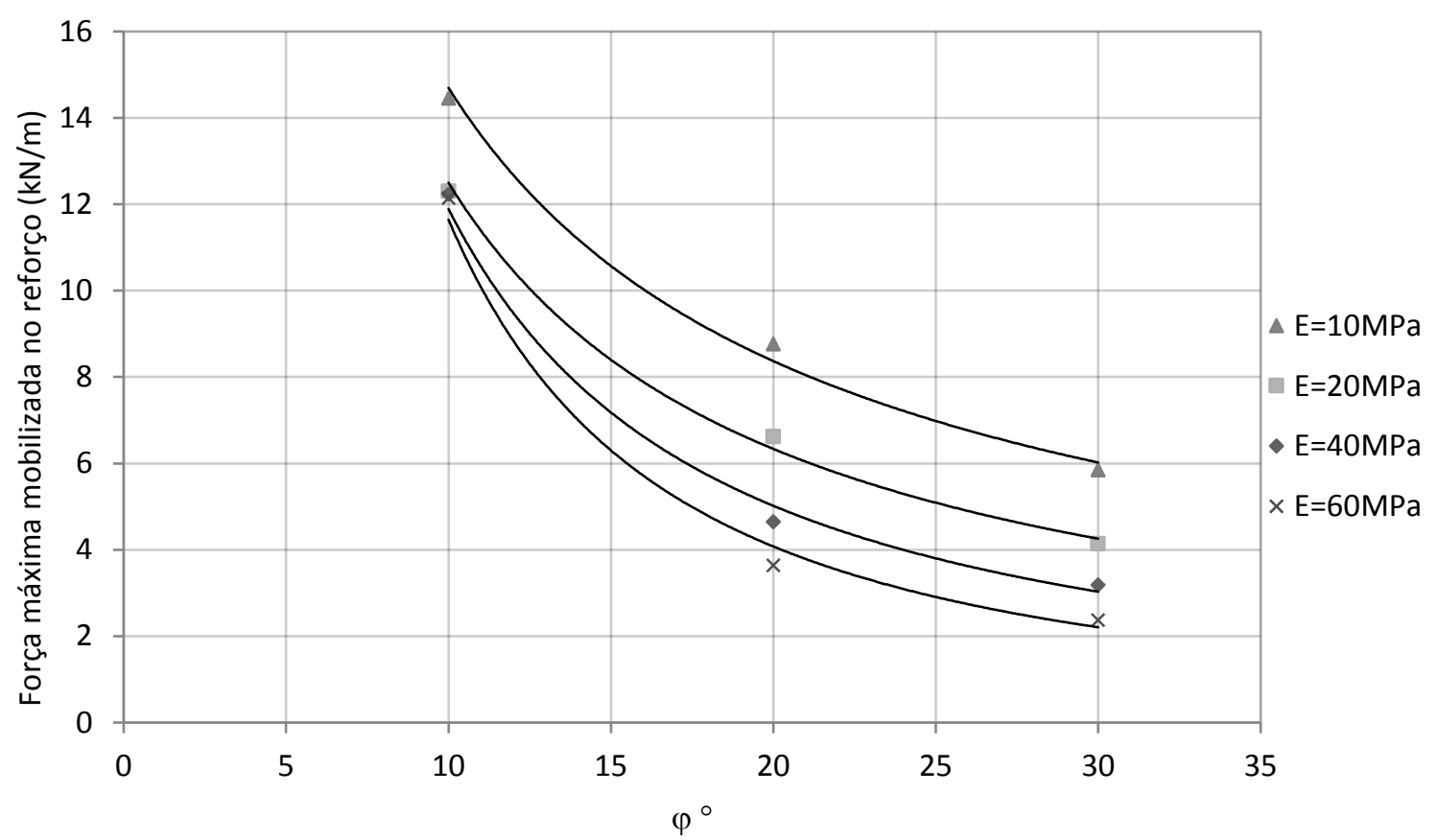

Fonte: Próprio autor

Neste ponto observa-se o inicio da estabilização dos deslocamentos em função do ângulo de atrito, pois as curvas de deslocamento máximo em função do ângulo de atrito são praticamente horizontais.

A Figura 5.24 e a Figura 5.25 mostram respectivamente os deslocamentos horizontais máximos na face e a força máxima mobilizada no reforço em função do ângulo de atrito do solo fixando-se a coesão (c=60 kPa). 
Figura 5.24 - Influência do ângulo de atrito no deslocamento horizontal - coesão $60 \mathrm{kPa}$

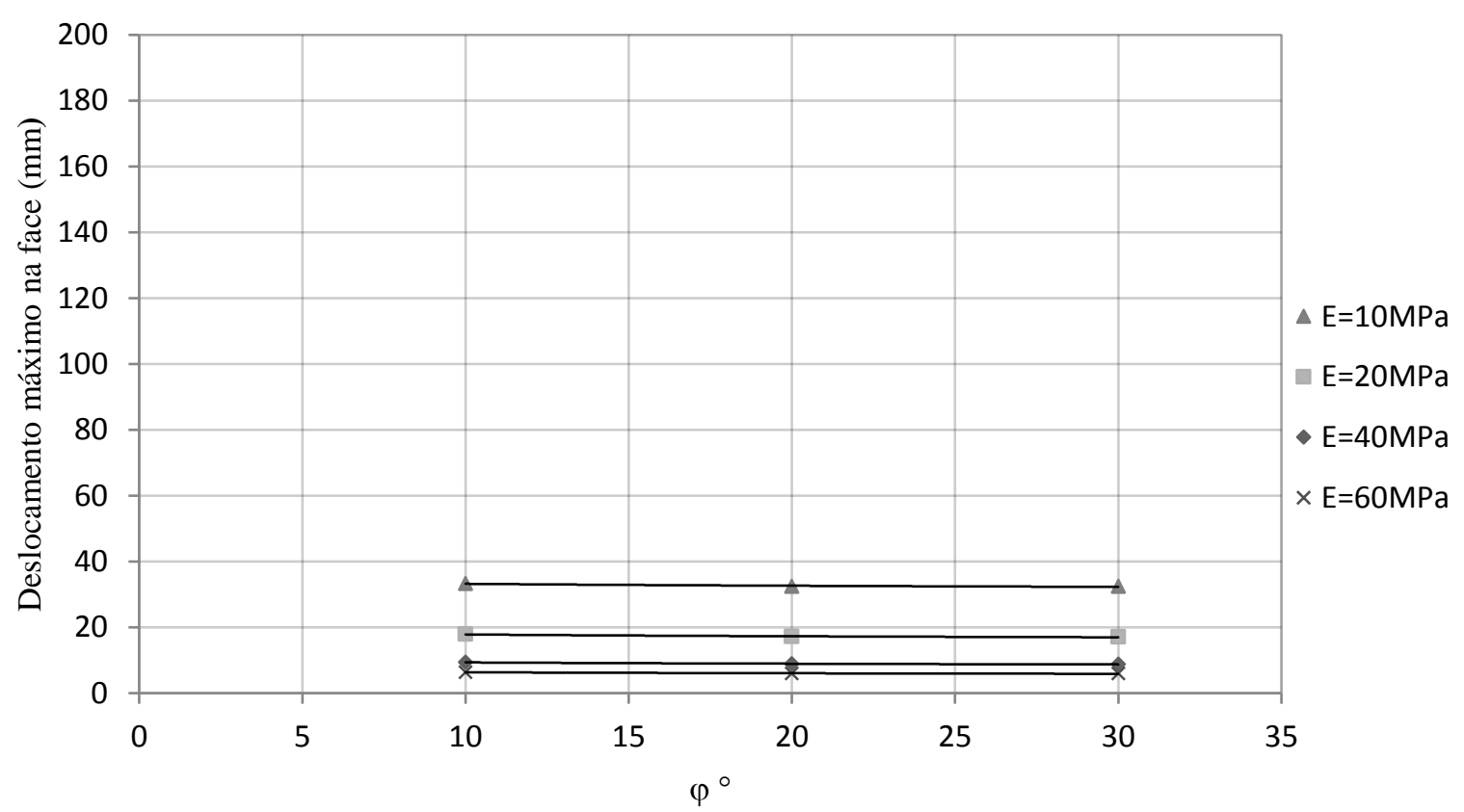

Fonte: Próprio autor

Figura 5.25- Influência do ângulo de atrito na mobilização do reforço - coesão 60 kPa

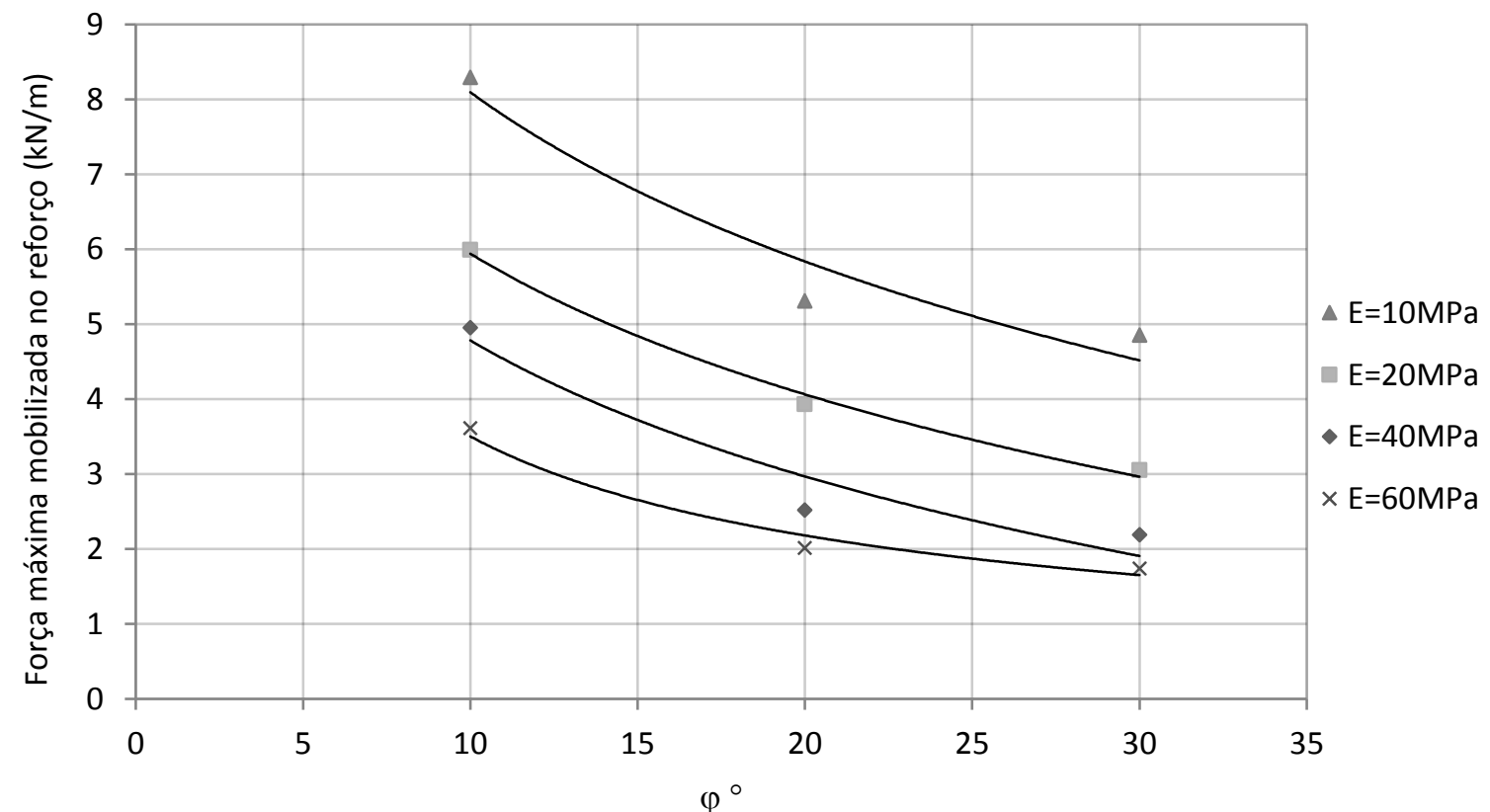

Fonte: Próprio autor

Por fim as curvas se aproximaram ainda mais de retas horizontais, com valores inferiores a $40 \mathrm{~mm}$ de deslocamento máximo na face para um MSRG de 10 $\mathrm{m}$ de altura, mostrando que para coesão de $60 \mathrm{kPa}$ o ângulo de atrito não influenciou a deformada do MSRG. 


\subsubsection{Estudo da influência da coesão do solo}

A Figura 5.26 e a Figura 5.27 mostram respectivamente os deslocamentos horizontais máximos na face e a força máxima mobilizada no reforço em função da coesão, fixado o módulo de elasticidade do solo ( $E=10 \mathrm{MPa})$.

Figura 5.26 - Influência da coesão no deslocamento horizontal - E=10 MPa

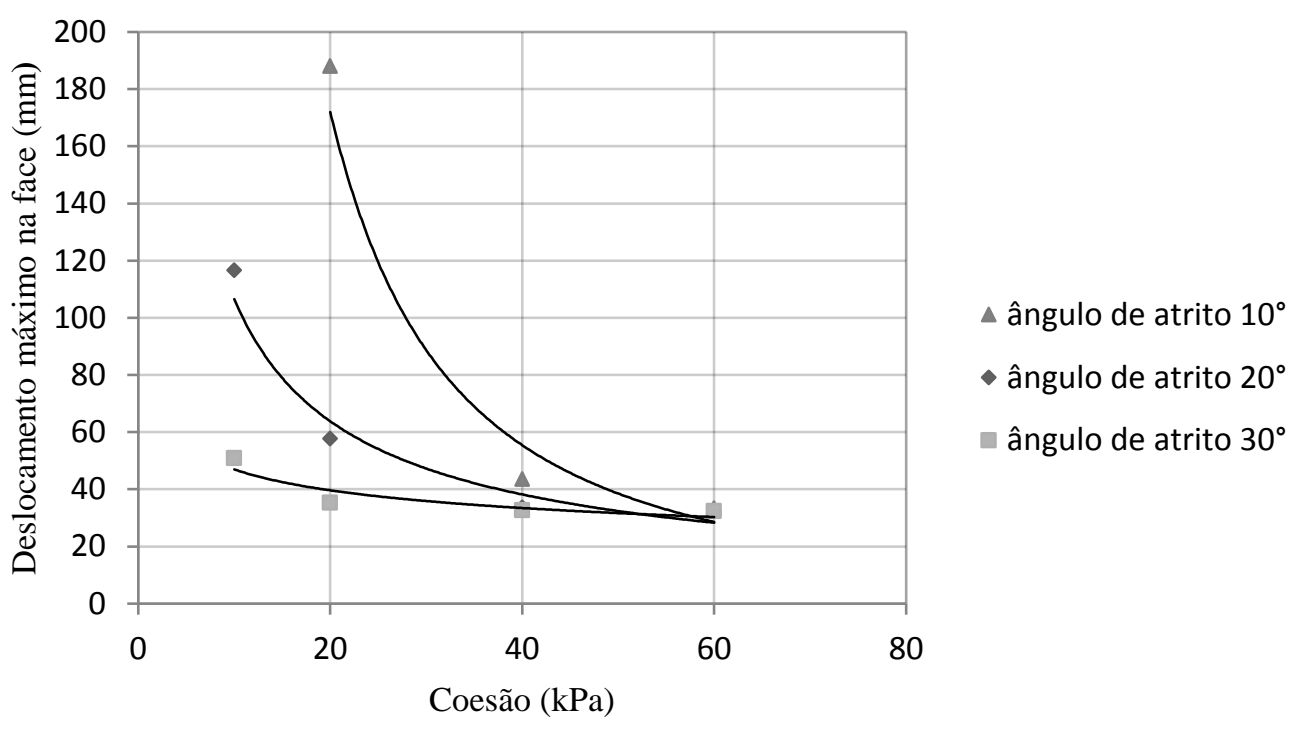

Fonte: Próprio autor

Figura 5.27- Influência da coesão na mobilização do reforço - E=10 MPa

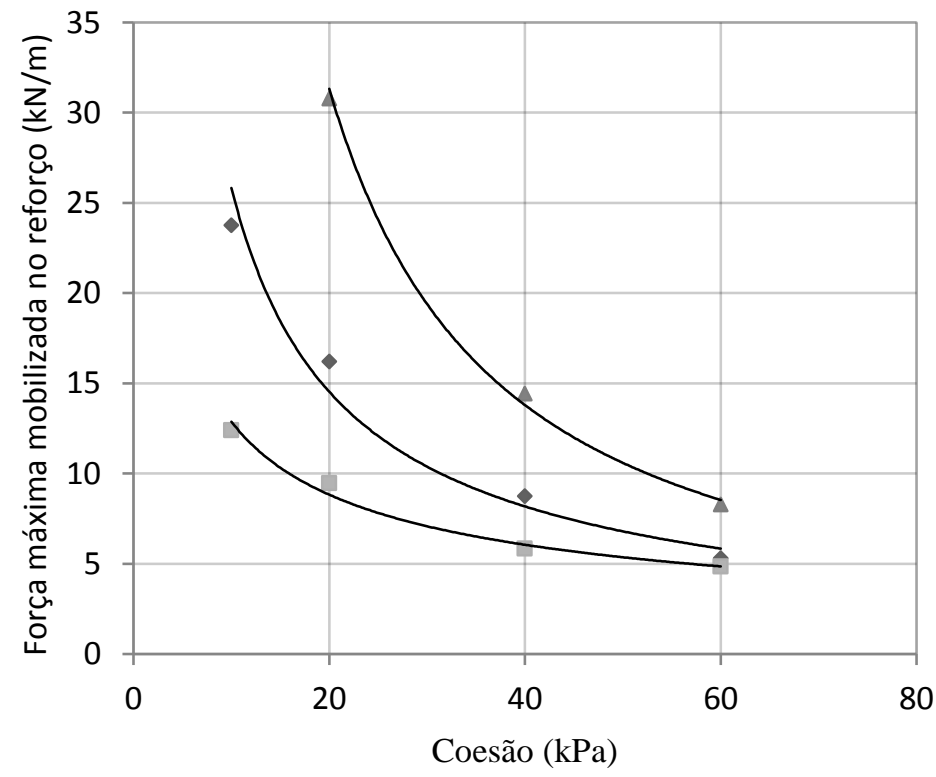

$\triangle$ ângulo de atrito $10^{\circ}$

- ângulo de atrito $20^{\circ}$

ângulo de atrito $30^{\circ}$

Fonte: Próprio autor 
A Figura 5.28 e a Figura 5.29 mostram respectivamente os deslocamentos horizontais máximos na face e a força máxima mobilizada no reforço em função da coesão, fixado o módulo de deformabilidade do solo ( $E=20 \mathrm{MPa}$ ).

Figura 5.28 - Influência da coesão no deslocamento horizontal - E=20 MPa

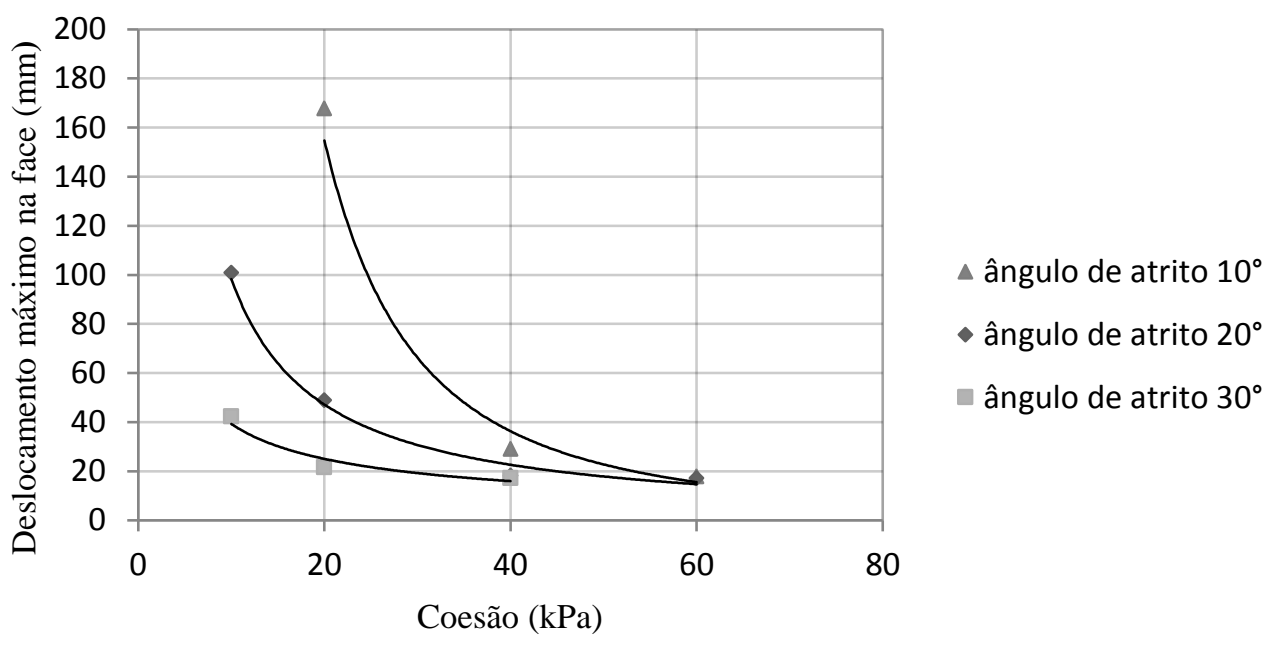

Fonte: Próprio autor

Figura 5.29- Influência da coesão na mobilização do reforço - E=20 MPa

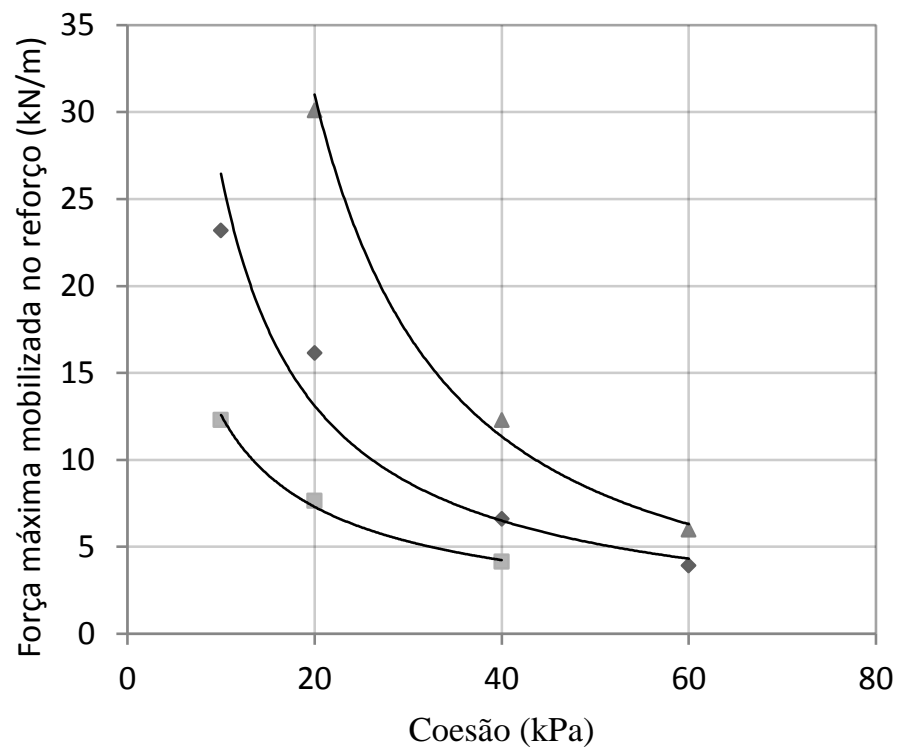

$\triangle$ ângulo de atrito $10^{\circ}$

- ângulo de atrito $20^{\circ}$

ângulo de atrito $30^{\circ}$

Fonte: Próprio autor 
A Figura 5.30 e a Figura 5.31 mostram respectivamente os deslocamentos horizontais máximos na face e a força máxima mobilizada no reforço em função da coesão, fixado o módulo de elasticidade do solo ( $E=40 \mathrm{MPa})$.

Figura 5.30 - Influência da coesão no deslocamento horizontal - E=40 MPa

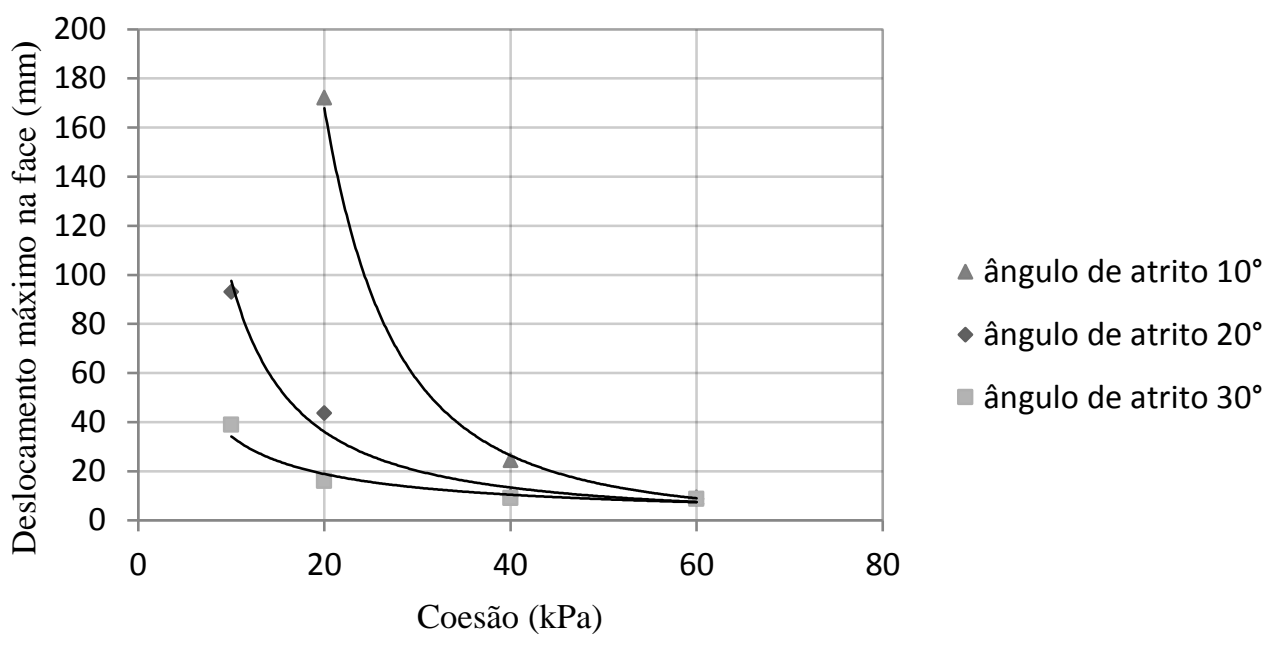

Fonte: Próprio autor

Figura 5.31- Influência da coesão na mobilização do reforço - E=40 MPa

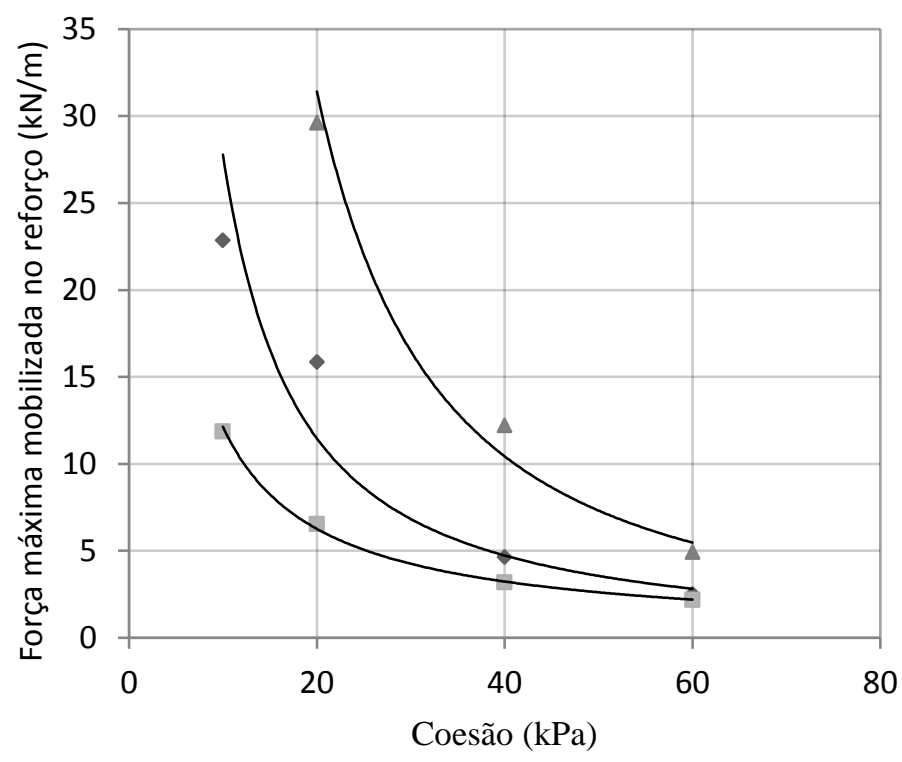

$\triangle$ ângulo de atrito $10^{\circ}$

- ângulo de atrito $20^{\circ}$

ângulo de atrito $30^{\circ}$

Fonte: Próprio autor 
A Figura 5.32 e a Figura 5.33 mostram respectivamente os deslocamentos horizontais máximos na face e a força máxima mobilizada no reforço em função da coesão, fixado o módulo de elasticidade do solo ( $E=60 \mathrm{MPa})$.

Figura 5.32 - Influência da coesão no deslocamento horizontal - E=60 MPa

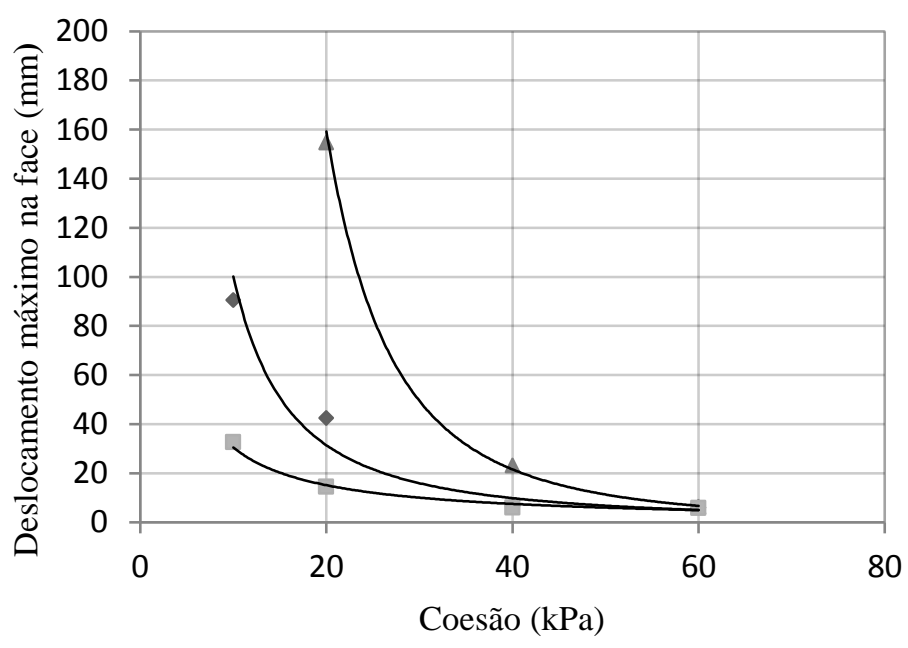

$\triangle$ ângulo de atrito $10^{\circ}$

- ângulo de atrito $20^{\circ}$

ângulo de atrito $30^{\circ}$

Fonte: Próprio autor

Figura 5.33- Influência da coesão na mobilização do reforço - E=60 MPa

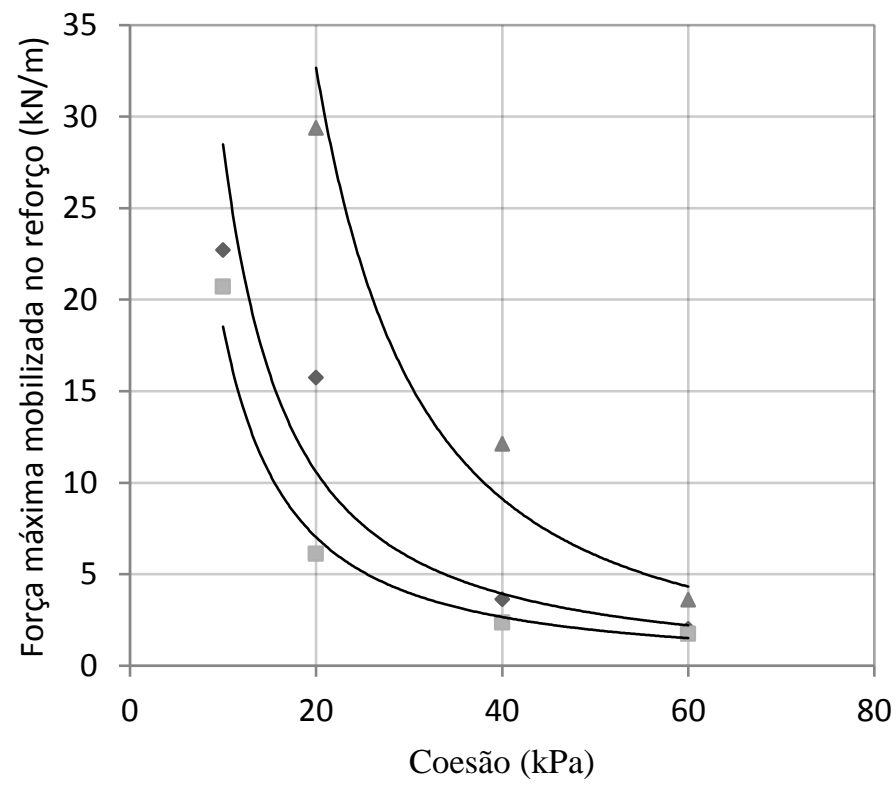

$\triangle$ ângulo de atrito $10^{\circ}$

- ângulo de atrito $20^{\circ}$

ângulo de atrito $30^{\circ}$

Fonte: Próprio autor 
Observa-se nas curvas da Figura 5.26 a Figura 5.32 que ao se aumentar a coesão diminuiu-se o deslocamento máximo na face, muito significativamente para o ângulo de atrito de $10^{\circ}(\sim 150 \mathrm{~mm})$ e menos significativamente para $30^{\circ}(\sim 20 \mathrm{~mm})$. As curvas tendem ao mesmo ponto para $\mathrm{C}=60 \mathrm{kPa}$, independente do ângulo de atrito. Comparando-se as quatro figuras, observa-se que o módulo de elasticidade não teve muita influência, apenas diminuiu de forma pouca acentuada o deslocamento máximo da face.

\subsubsection{Estudo da influência do módulo de elasticidade do solo}

A Figura 5.34 e a Figura 5.35 mostram respectivamente os deslocamentos horizontais máximos na face e a força máxima mobilizada no reforço em função do módulo de elasticidade do solo, fixada a coesão ( $\mathrm{c}=10 \mathrm{kPa})$.

Figura 5.34 - Influência do módulo de elasticidade no deslocamento horizontal máximocoesão $10 \mathrm{kPa}$

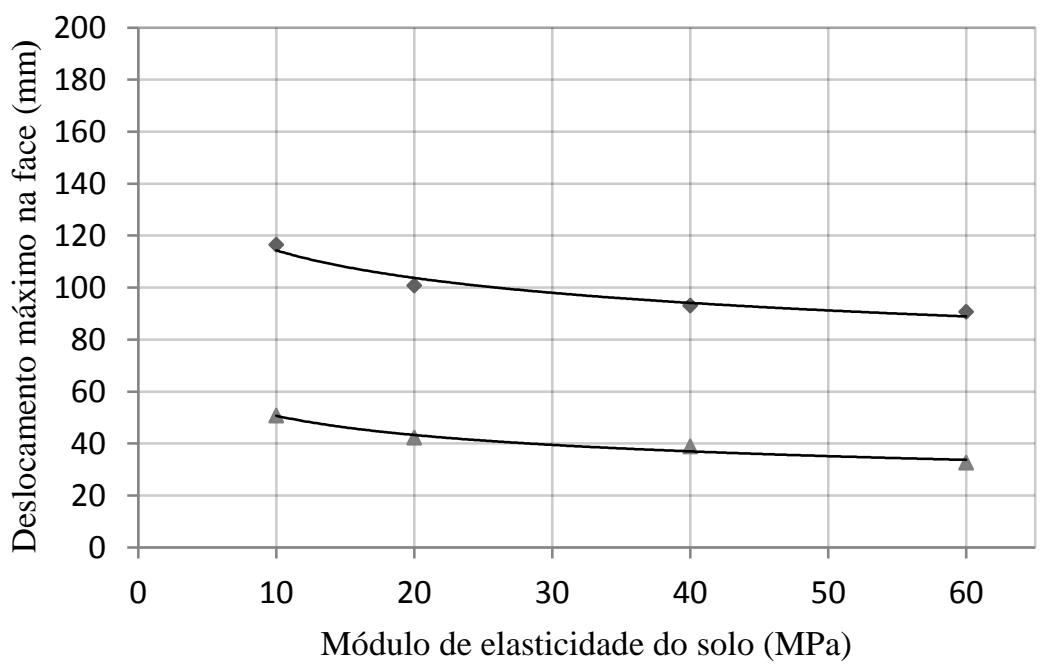

$\times$ ângulo de atrito $10^{\circ}$

- ângulo de atrito $20^{\circ}$

$\Delta$ ângulo de atrito $30^{\circ}$

Fonte: Próprio autor 
Figura 5.35- Influência do módulo de elasticidade na força máxima mobilizada no reforçocoesão $10 \mathrm{kPa}$

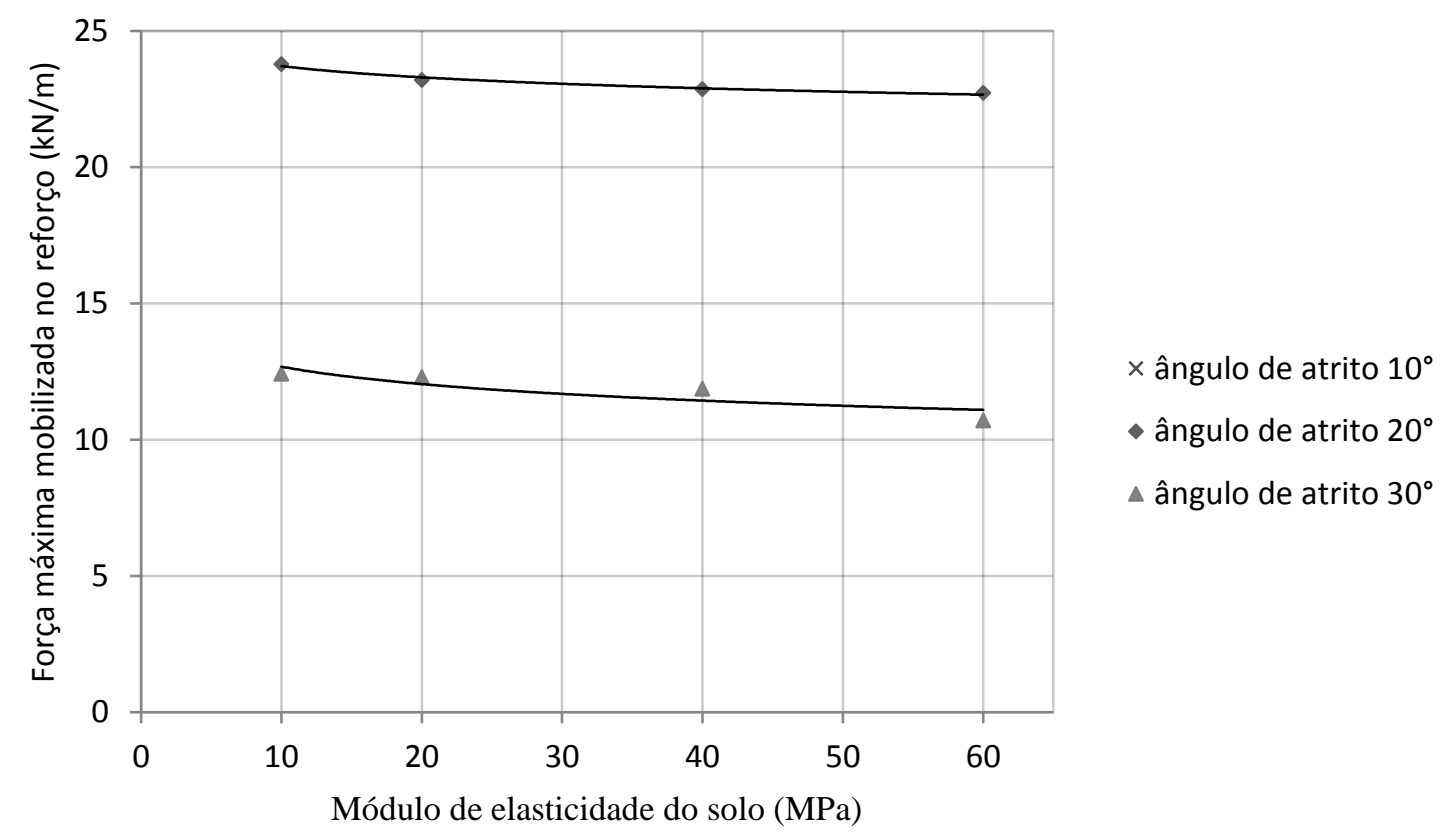

Fonte: Próprio autor

Houve o colapso da estrutura para o ângulo de atrito de $10^{\circ}$ e coesão 10 $\mathrm{kPa}$, para os 4 módulos de elasticidade simulados. O aumento do modulo de elasticidade do solo resultou em uma diminuição do deslocamento máximo da face, como esperado, porém esse parâmetro mostrou muito menos influencia que os parâmetros de resistência.

A Figura 5.36 e a Figura 5.37 mostram respectivamente os deslocamentos horizontais máximos na face e a força máxima mobilizada no reforço em função do módulo de elasticidade do solo fixado a coesão ( $c=20 \mathrm{kPa})$. 
Figura 5.36 - Influência do módulo de elasticidade no deslocamento horizontal máximocoesão $20 \mathrm{kPa}$

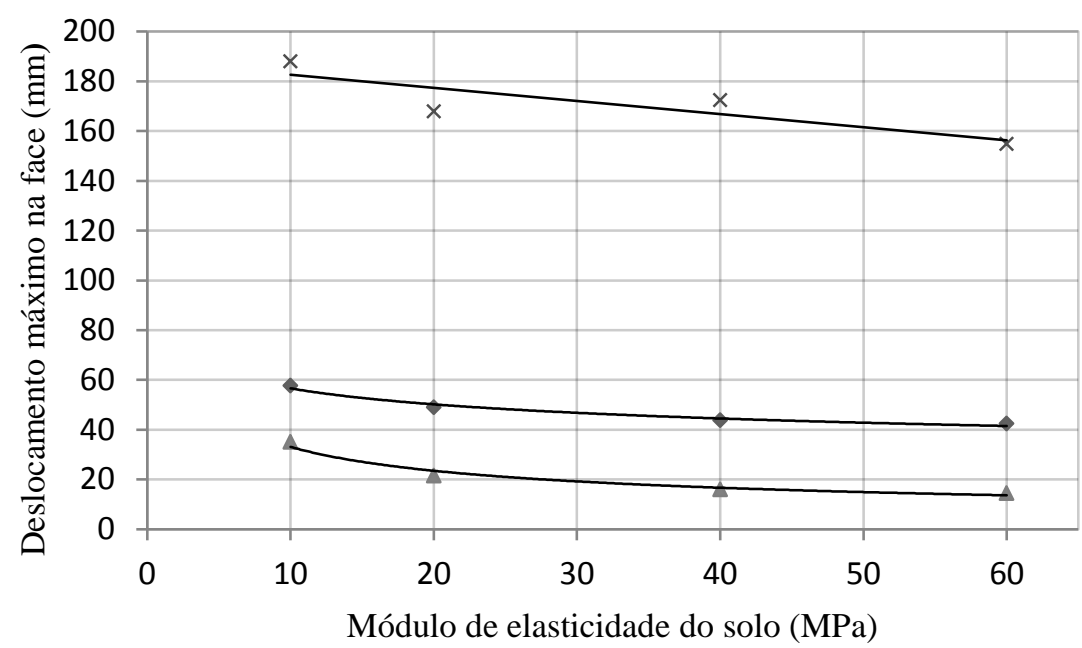

$\times$ ângulo de atrito $10^{\circ}$

- ângulo de atrito $20^{\circ}$

$\triangle$ ângulo de atrito $30^{\circ}$

Fonte: Próprio autor

Figura 5.37- Influência do módulo de elasticidade na força máxima mobilizada no reforço - coesão $20 \mathrm{kPa}$

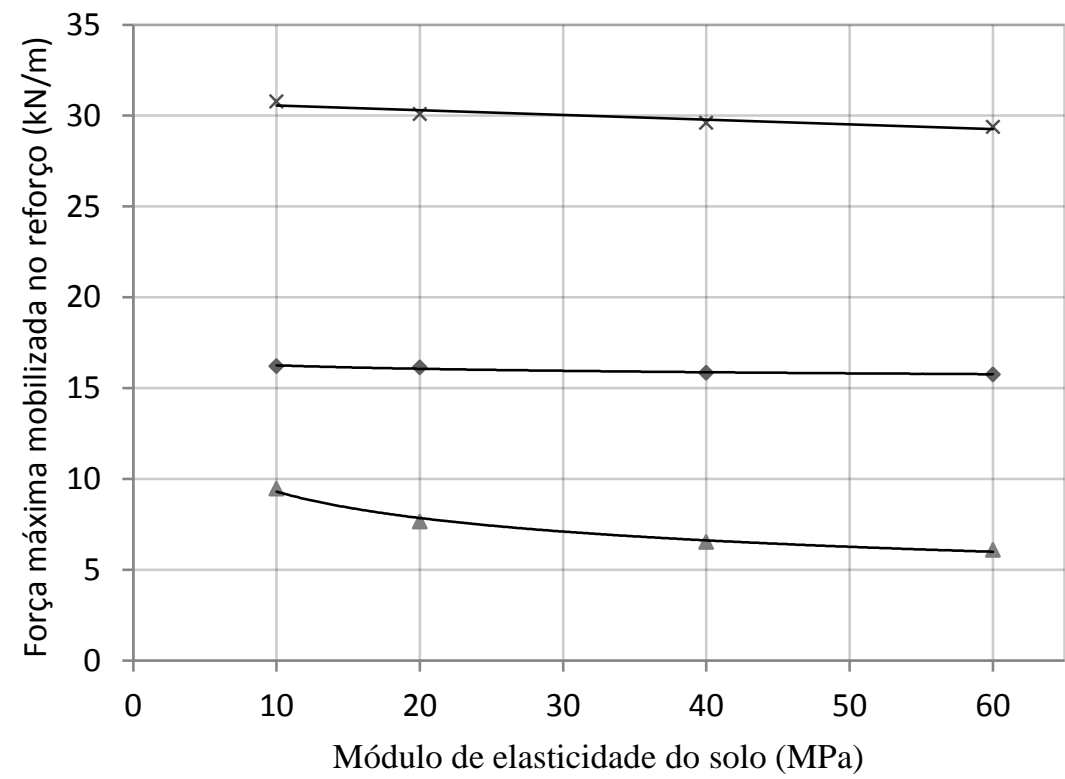

$\times$ ângulo de atrito $10^{\circ}$

- ângulo de atrito $20^{\circ}$

$\triangle$ ângulo de atrito $30^{\circ}$

Fonte: Próprio autor 
A Figura 5.38 e a Figura 5.39 mostram respectivamente os deslocamentos horizontais máximos na face e a força máxima mobilizada no reforço em função do módulo de elasticidade do solo fixado a coesão ( $\mathrm{c}=40 \mathrm{kPa})$.

Figura 5.38 - Influência do módulo de elasticidade no deslocamento horizontal - coesão $40 \mathrm{kPa}$

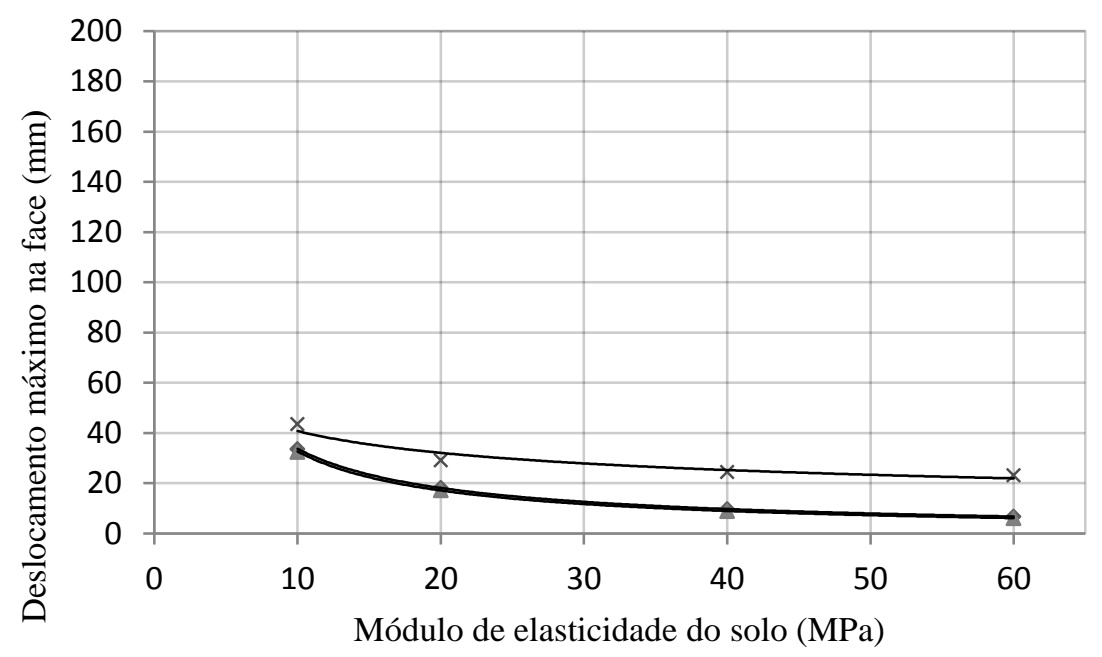

$\times$ ângulo de atrito $10^{\circ}$

- ângulo de atrito $20^{\circ}$

$\triangle$ ângulo de atrito $30^{\circ}$

Fonte: Próprio autor

Figura 5.39- Influência do módulo de elasticidade na força máxima mobilizada no reforço - coesão $40 \mathrm{kPa}$

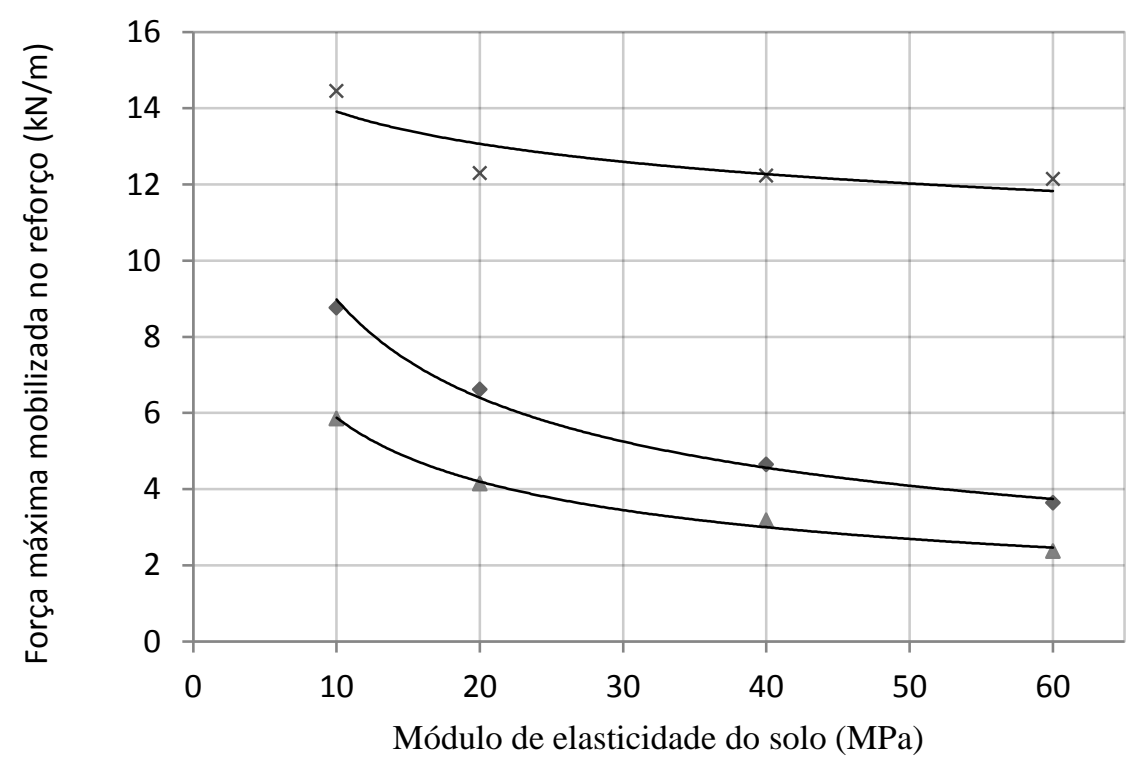

$\times$ ângulo de atrito $10^{\circ}$

- ângulo de atrito $20^{\circ}$

$\triangle$ ângulo de atrito $30^{\circ}$

Fonte: Próprio autor 
A Figura 5.40 e a Figura 5.41 mostram respectivamente os deslocamentos horizontais máximos na face e a força máxima mobilizada no reforço em função do módulo de elasticidade do solo fixado a coesão (c=60 kPa).

Figura 5.40 - Influência do módulo de elasticidade no deslocamento horizontal máximocoesão $60 \mathrm{kPa}$

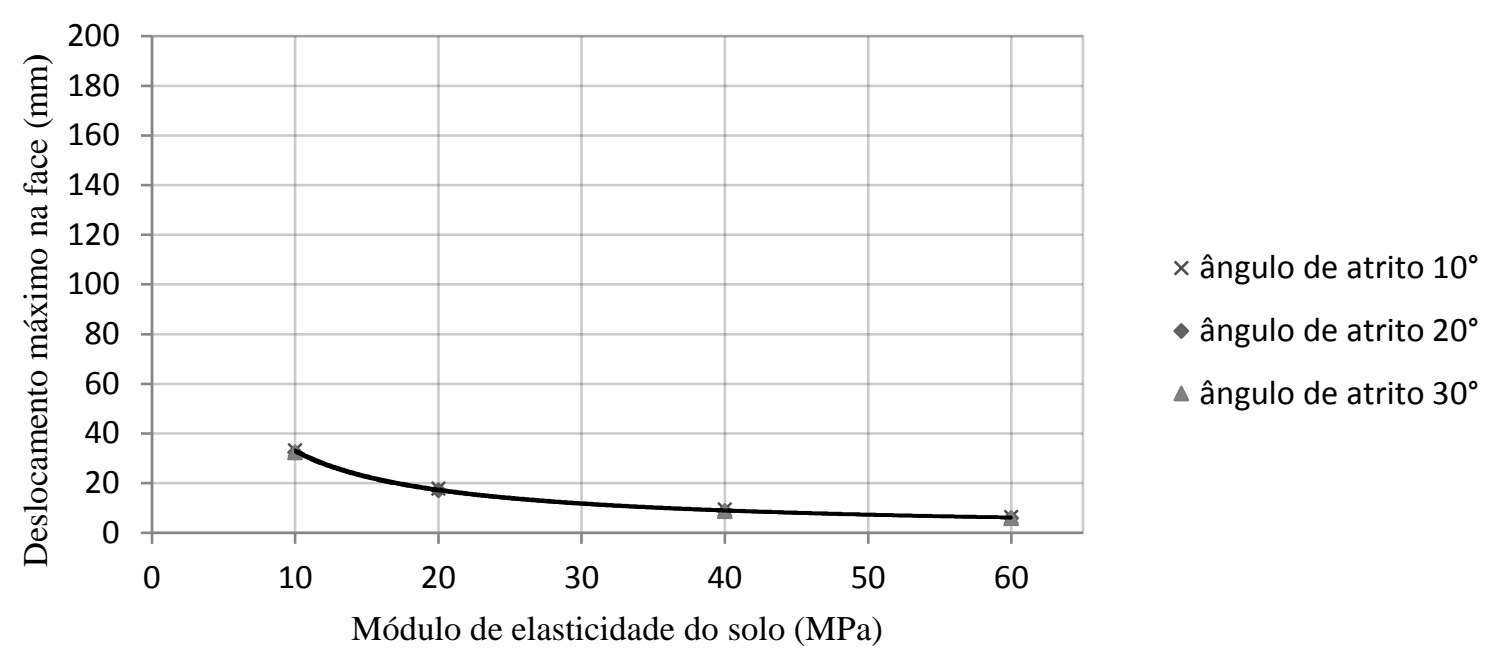

Fonte: Próprio autor

Figura 5.41- Influência do módulo de elasticidade na força máxima mobilizada no reforço - coesão $60 \mathrm{kPa}$

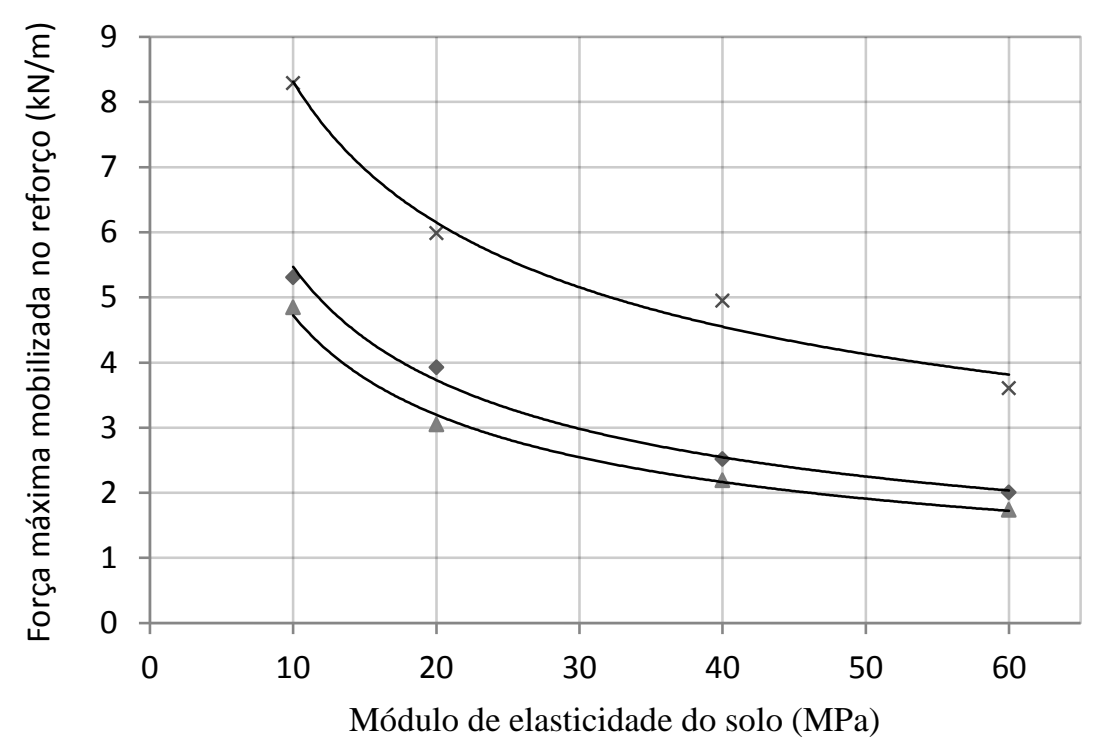

$\times$ ângulo de atrito $10^{\circ}$

- ângulo de atrito $20^{\circ}$

$\triangle$ ângulo de atrito $30^{\circ}$

Fonte: Próprio autor 
Da Figura 5.36 a Figura 5.40, observa-se que o aumento do módulo de elasticidade do solo diminui o deslocamento máximo da face do muro, mas que essa influência não é tão significativa para E variando de 10 a $60 \mathrm{MPa}$. Quando o solo deforma, mobiliza o reforço, que passa atuar em conjunto; um solo mais deformável mobiliza mais o reforço, assim a rigidez do conjunto solo-reforço pode não se diferenciar tanto daquela de um solo menos deformável.

Uma possível causa dos parâmetros de resistência terem influenciado mais no comportamento do muro do que a rigidez do solo é que boa parte da massa de solo entrou em escoamento pelo critério de Mohr-Coulomb. Isso ocorre quando as tensões desviatórias superam as tensões de ruptura segundo os parâmetros de resistência do solo (coesão e ângulo de atrito), acarretando deformações plásticas e redistribuição da carga ao longo do maciço. As deformações plásticas do solo são significativamente maiores do que as que ocorrem na região elástica. Dessa forma o que rege o comportamento do muro passa a ser os parâmetros de resistência do solo, e não mais sua rigidez. De fato boa parte do MSRG nas simulações numéricas tem o solo plastificado, como mostra a Figura 5.42 .

Figura 5.42- Solo plastificado na simulação PAR 18

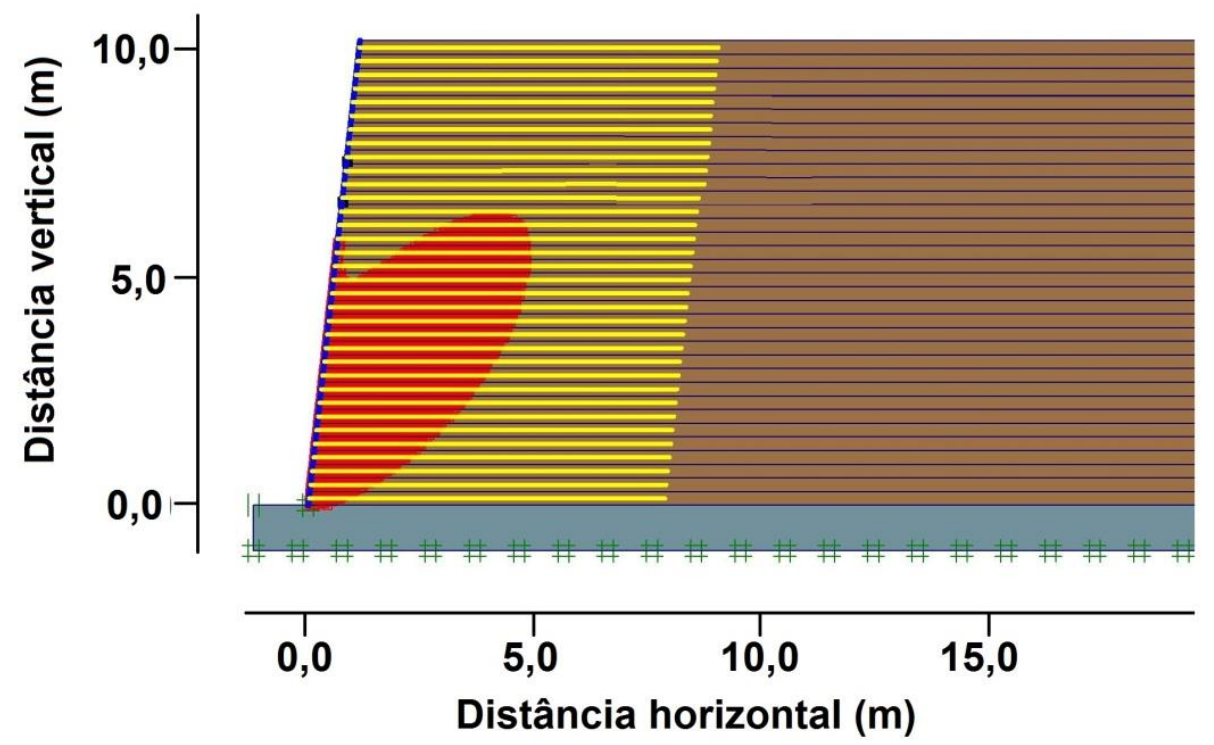

Fonte: Próprio autor

A figura mostra a saída do software PLAXIS dos elementos que estão em escoamento plástico (em vermelho) de uma das simulações deste capítulo (PAR 18). Pode-se inferir qual a potencial superfície de ruptura, onde o solo se encontra em 
escoamento plástico. Portanto nas simulações com os maiores deslocamentos o comportamento do MSRG é dado principalmente em função dos parâmetros de resistência do solo. A Figura 5.43 mostra a variação da potencial superfície de ruptura ao se variar os parâmetros de resistência e rigidez do solo em MSRG com a rigidez do reforço de 1000 kN/m e 10 metros de altura. Foram selecionadas algumas combinações que apresentaram valores extremos de deslocamento de face. Assim como no item anterior, as curvas da potencial superfície de ruptura não apresentaram uma tendência clara em relação à variação paramétrica.

Figura 5.43 - Influência da variação paramétrica do solo na potencial superfície de ruptura de MSRG com reforço de rigidez de $1000 \mathrm{kN} / \mathrm{m}$
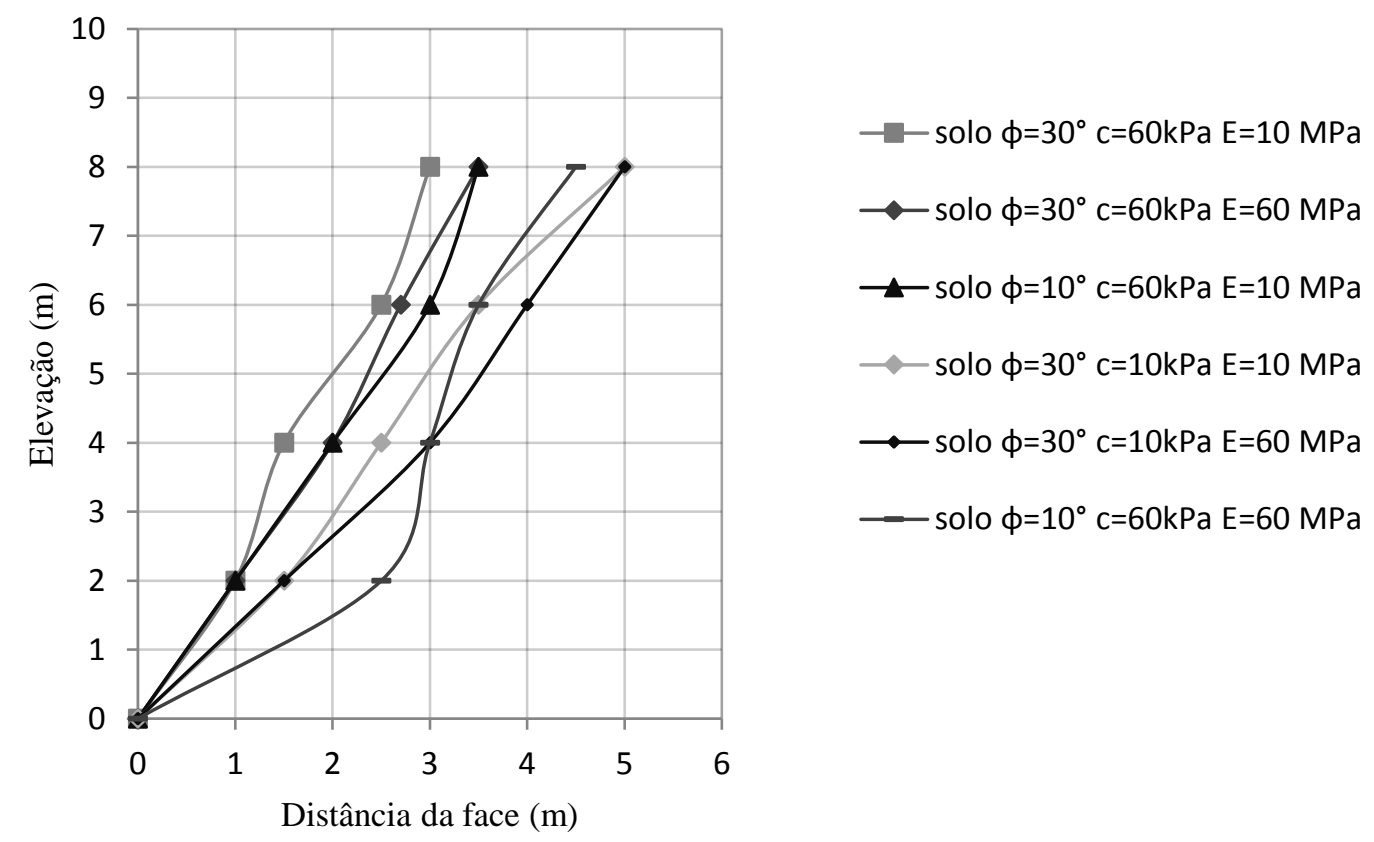


\subsection{SIMULAÇÕES DE MSRG DE 10 M DE ALTURA COM VARIAÇÕES DA INCLINAÇÃO DO MURO}

Os dados utilizados nesta parte foram extraídos das simulações identificadas com a sigla "INCL". Os dados foram ordenados de modo que se possa observar a variação no comportamento do MSRG ao se modificar a inclinação da face. Foram fixados os seguintes parâmetros: rigidez do geossintético ( $J=1.000 \mathrm{kN} / \mathrm{m})$; espaçamento vertical do geossintético $(\mathrm{e}=30 \mathrm{~cm})$; altura do muro $(\mathrm{H}=10 \mathrm{~m})$; comprimento do reforço $(\mathrm{L}=8 \mathrm{~m})$, e elemento Plate na face.

A Figura 5.44 e a Figura 5.45 mostram respectivamente os deslocamentos horizontais máximos na face e a força máxima mobilizada no reforço em função da inclinação da face, fixados a coesão (c=20 kPa) e módulo de elasticidade do solo $(\mathrm{E}=10 \mathrm{MPa})$.

Figura 5.44 - Influência da inclinação da face no deslocamento horizontal máximo coesão $20 \mathrm{kPa}$ e E=10 MPa

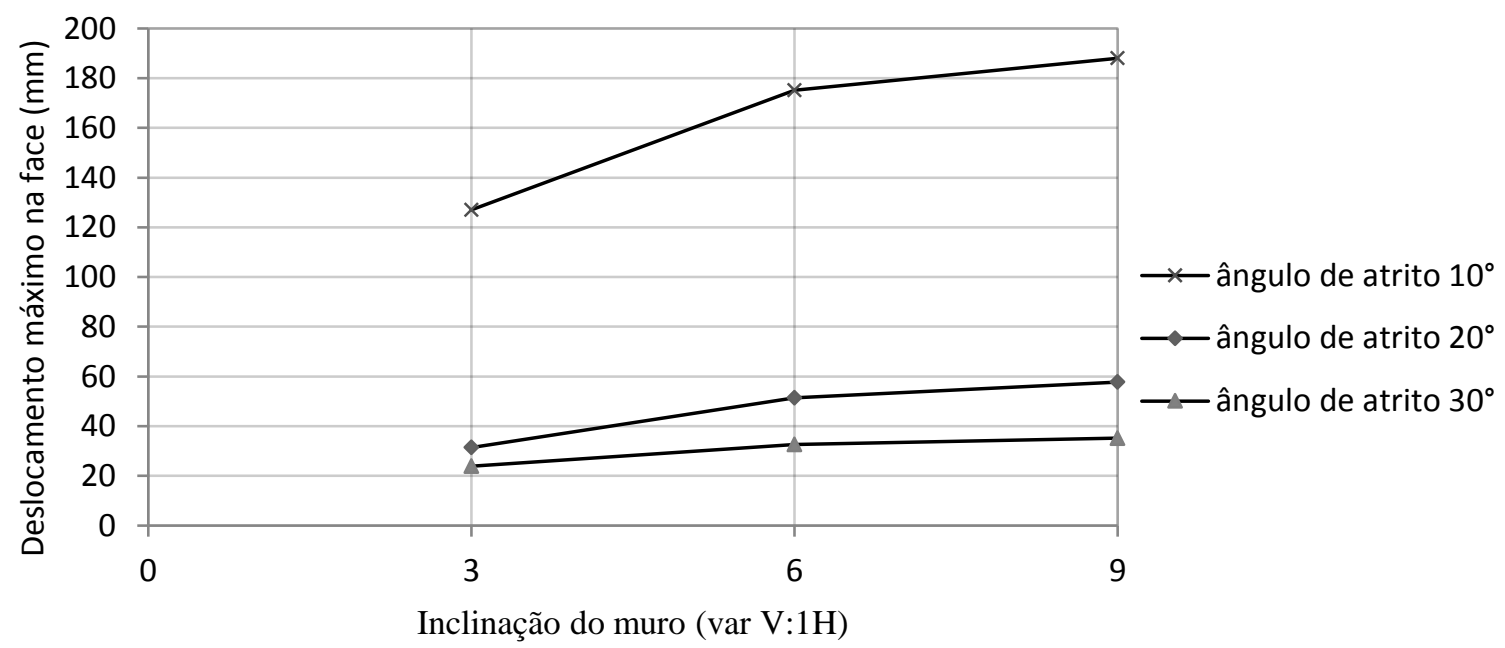

Fonte: Próprio autor 
Figura 5.45- Influência da inclinação da face na força máxima mobilizada no reforço coesão $20 \mathrm{kPa}$ e $\mathrm{E}=10 \mathrm{MPa}$

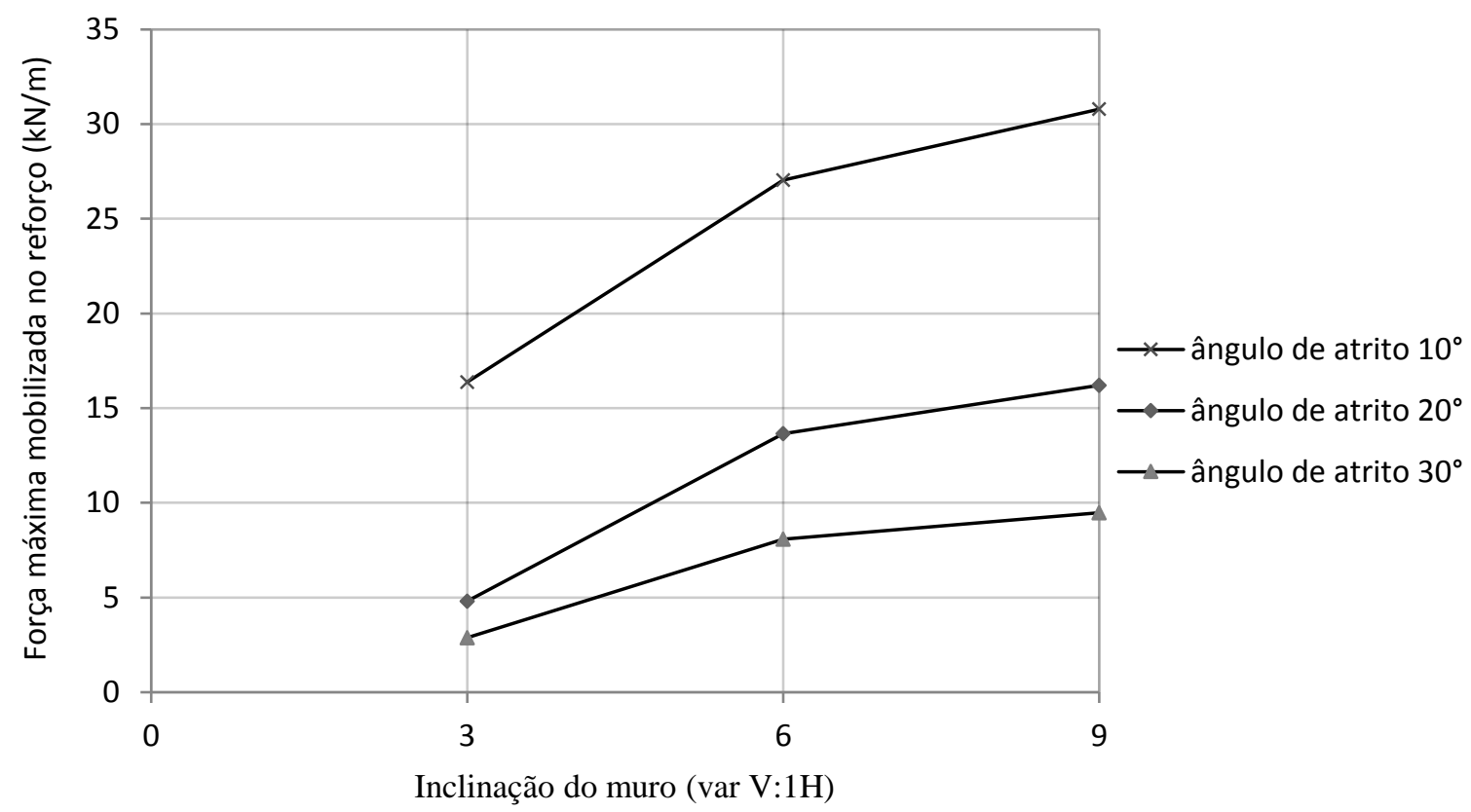

Fonte: Próprio autor

Foi observado um aumento dos deslocamentos ao se aumentar a inclinação do muro. No solo com o ângulo de atrito de $10^{\circ}$, os deslocamentos foram maiores e também maior foi a influência da inclinação do muro.

A Figura 5.46 e a Figura 5.47 mostram respectivamente os deslocamentos horizontais máximos na face e a força máxima mobilizada no reforço em função da inclinação da face, fixados a coesão $(c=20 \mathrm{kPa})$ e módulo de elasticidade do solo $(\mathrm{E}=60 \mathrm{MPa})$. 
Figura 5.46 - Influência da inclinação da face no deslocamento horizontal máximo coesão $20 \mathrm{kPa}$ e E=60 MPa

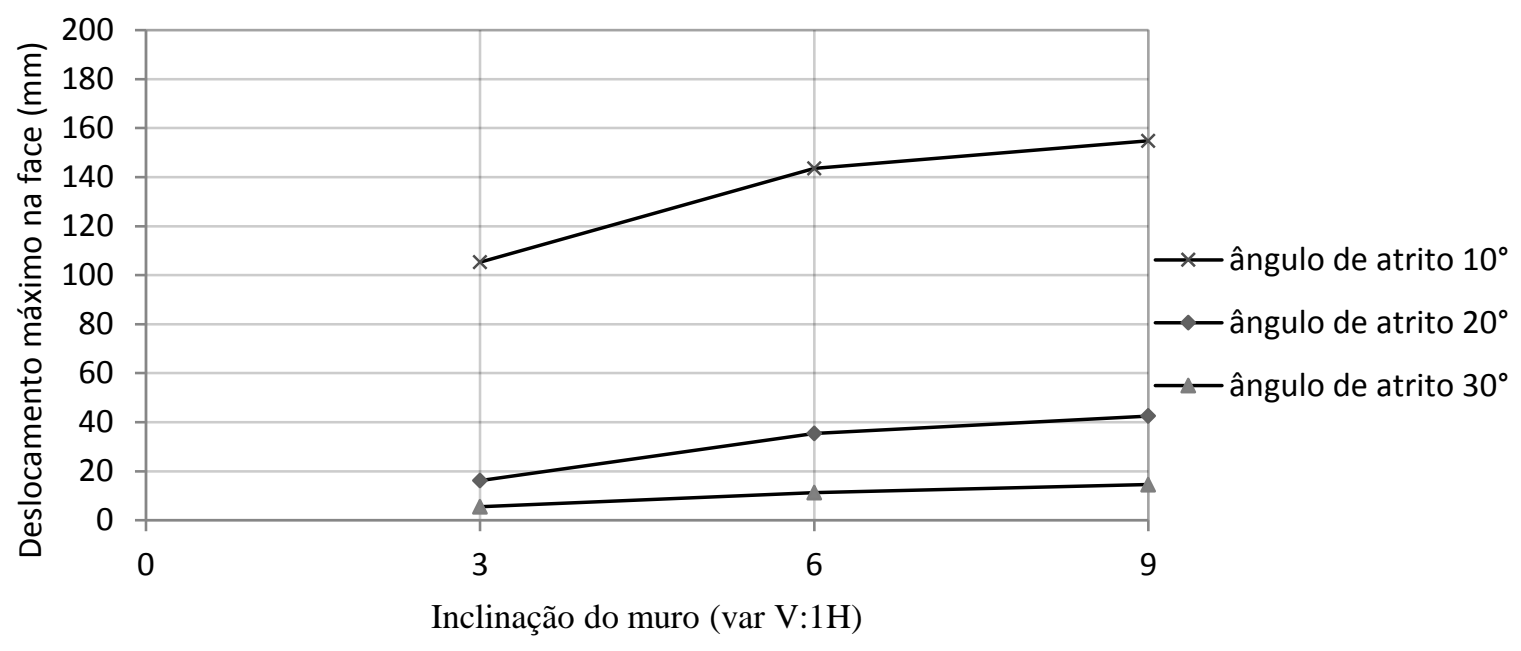

Fonte: Próprio autor

Figura 5.47- Influência da inclinação da face na força máxima mobilizada no reforço coesão $20 \mathrm{kPa}$ e E=60 MPa

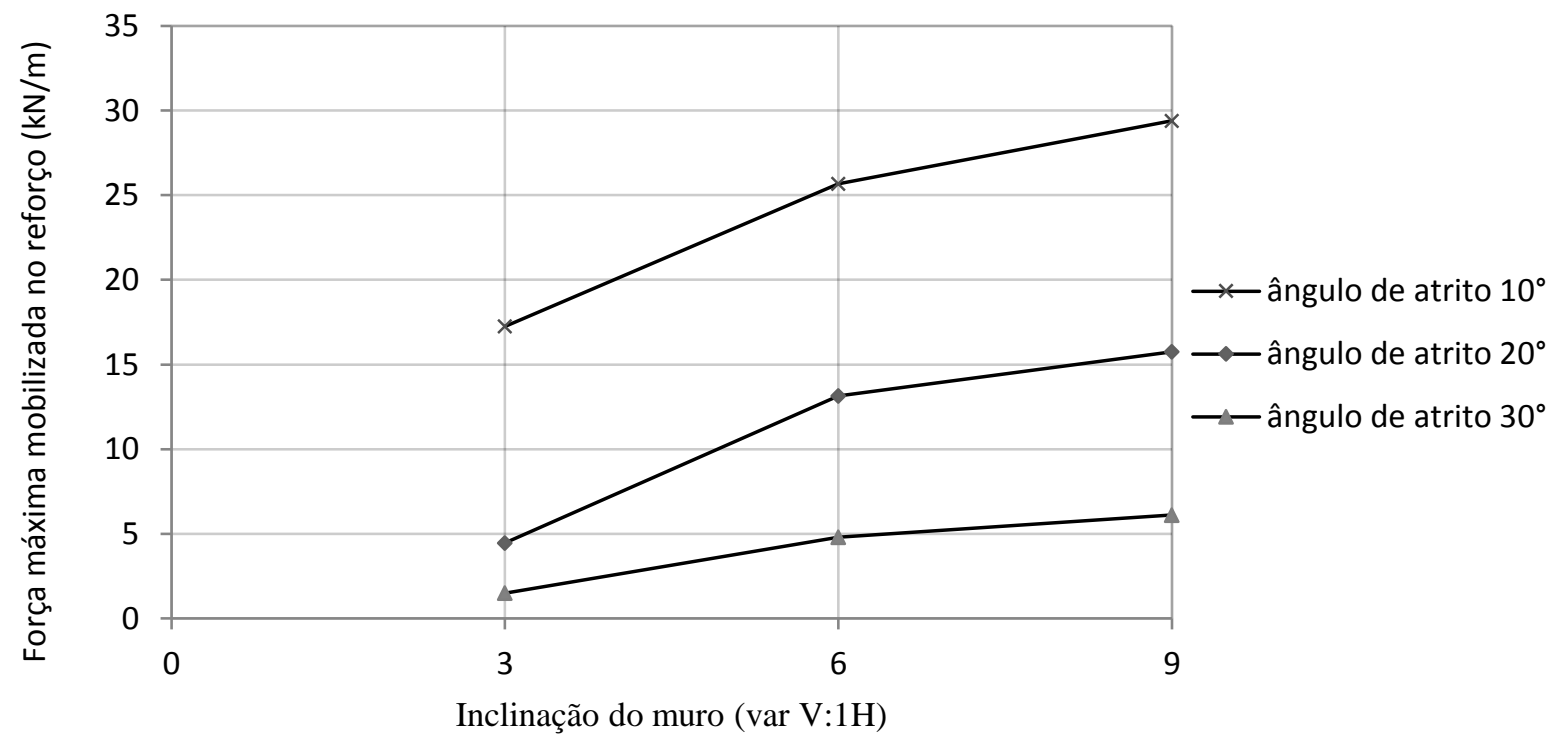

Fonte: Próprio autor 
Com o aumento do módulo de elasticidade do solo houve uma sutil diferença nos deslocamentos, porém as configurações das curvas se mantiveram, indicando elas independem do módulo de elasticidade do solo.

A Figura 5.48 e a Figura 5.49 mostram respectivamente os deslocamentos horizontais máximos na face e a força máxima mobilizada no reforço em função da inclinação da face, fixados o ângulo de atrito $\left(\varphi=20^{\circ}\right)$ e módulo de elasticidade do solo $(E=10 \mathrm{MPa})$.

Figura 5.48 - Influência da inclinação da face no deslocamento horizontal máximo ângulo de atrito $\left(\varphi=20^{\circ}\right)$ e $E=10 \mathrm{MPa}$

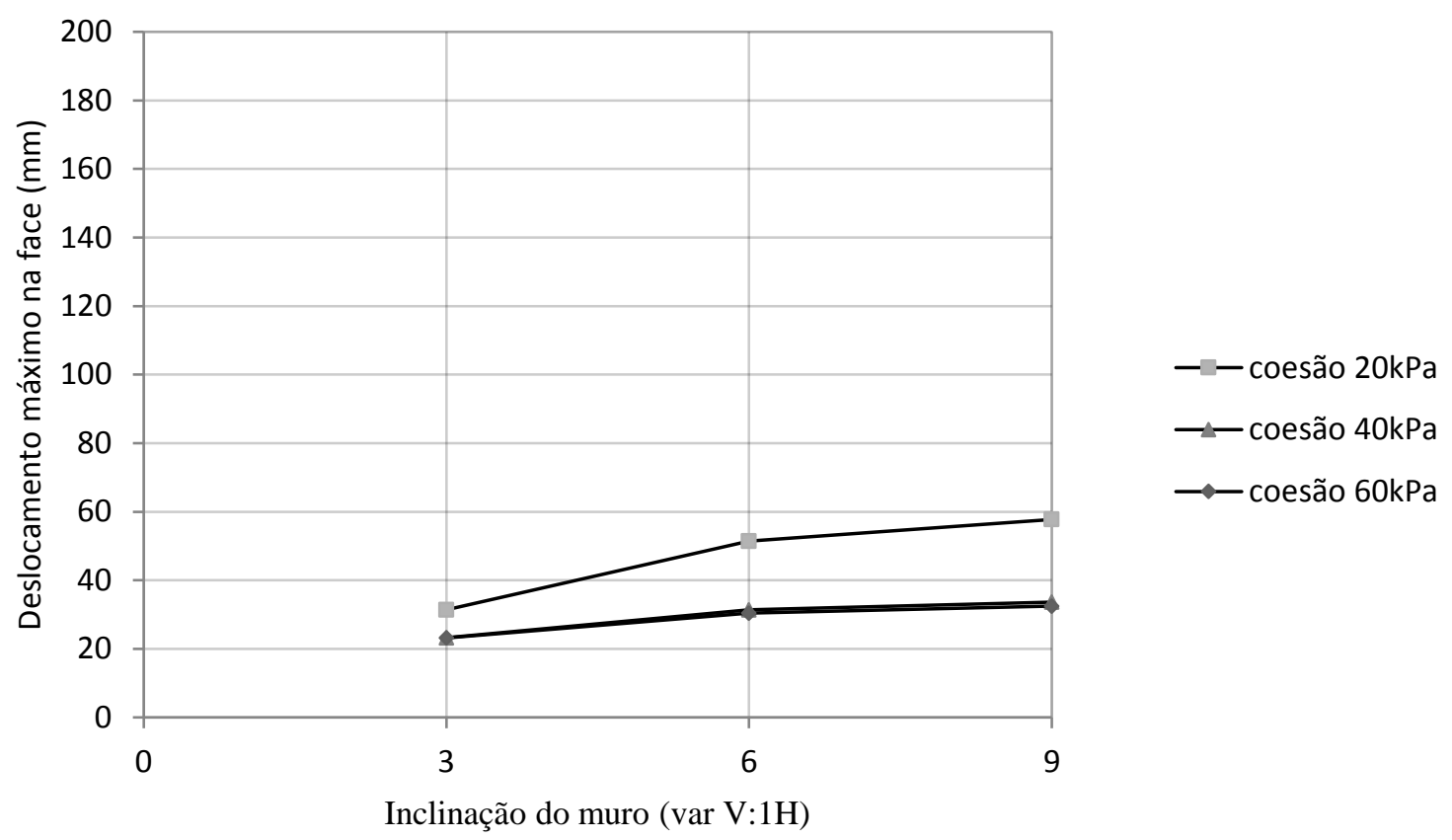

Fonte: Próprio autor 
Figura 5.49- Influência da inclinação da face na força máxima mobilizada no reforço ângulo de atrito $\left(\varphi=20^{\circ}\right)$ e $E=10 \mathrm{MPa}$

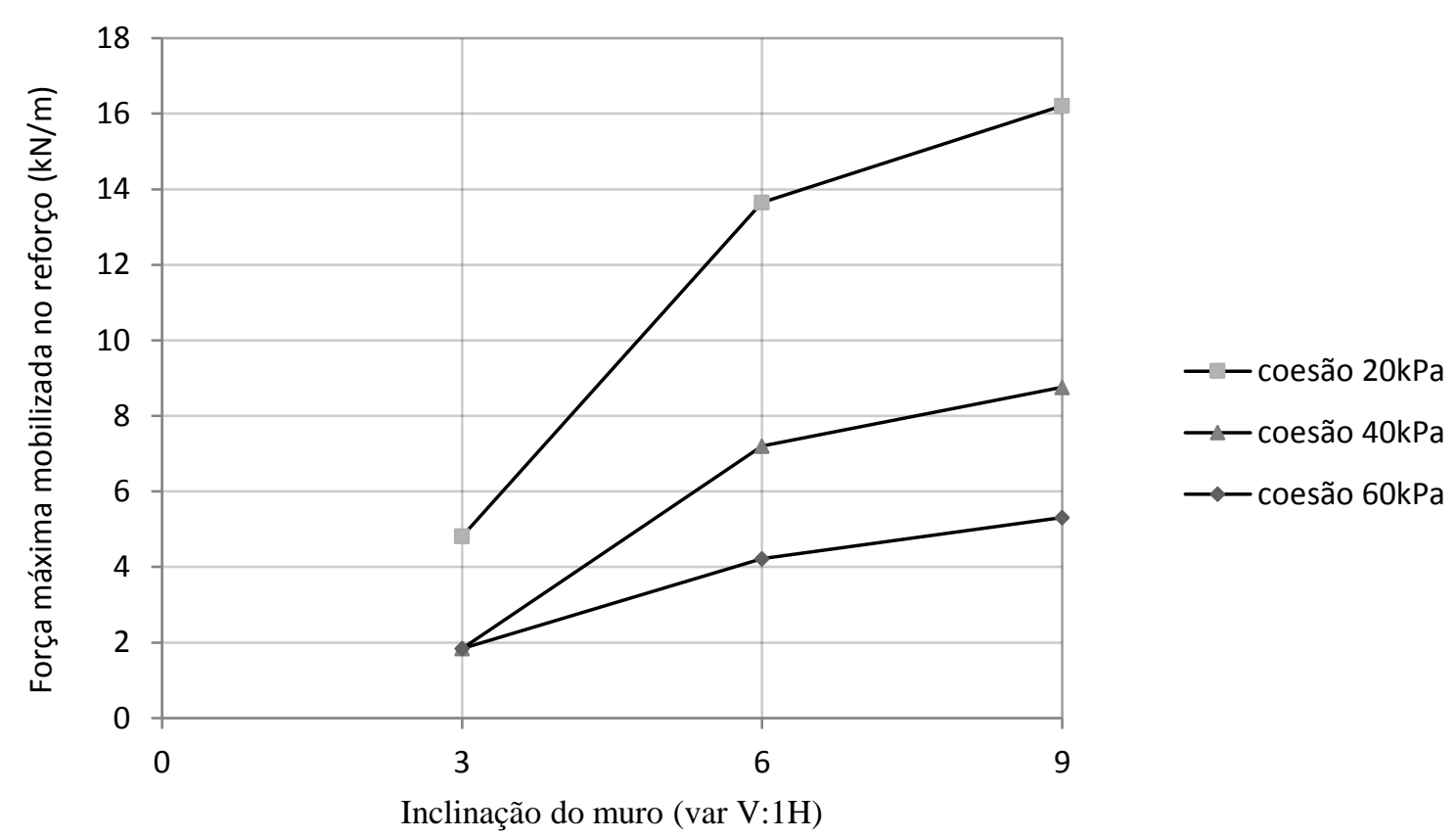

Fonte: Próprio autor

Pode-se observar que a partir de certo valor de coesão (40 e $60 \mathrm{kPa}$ ) as curvas se mantiveram praticamente idênticas, indicando elevada resistência do solo para esta situação. Como nos casos anteriores, a inclinação do MSRG acarretou um aumento do deslocamento máximo na face, de intensidade mediana se comparada em percentual, de 20 para $30 \mathrm{~mm}$, porém com valores absolutos baixos em comparação aos $190 \mathrm{~mm}$ do caso mais crítico.

\subsection{SIMULAÇÕES DE MSRG DE 10 M DE ALTURA COM ENVELOPAMENTO COM VARIAÇÕES DE ESPAÇAMENTO E RIGIDEZ DO REFORÇO}

Os dados utilizados nesta parte foram extraídos das simulações identificadas com a sigla "ESP". Foram fixados os seguintes parâmetros: altura do muro $(\mathrm{H}=10$ $\mathrm{m})$; comprimento do reforço $(L=8 \mathrm{~m})$; elemento Plate na face; inclinação da face (9V:1H), e módulo de elasticidade de solo (E=30 MPa). A Figura 5.50 e a Figura 5.51 mostram respectivamente os deslocamentos horizontais máximos na face e a força máxima mobilizada no reforço em função do espaçamento do reforço. 
Figura 5.50 - Influência do espaçamento do reforço no deslocamento horizontal máximo

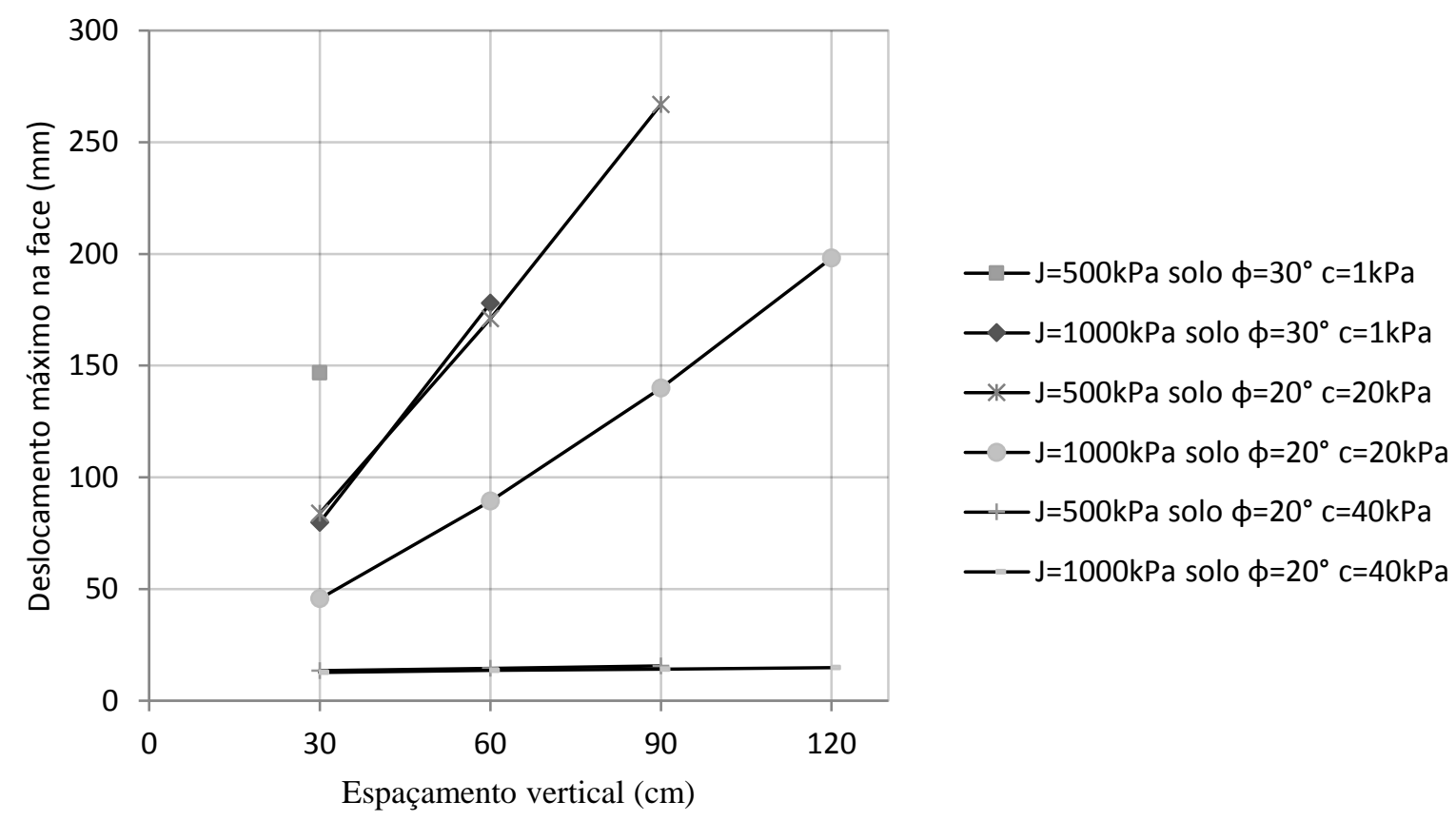

Fonte: Próprio autor

Figura 5.51- Influência do espaçamento do reforço na força mobilizada no reforço

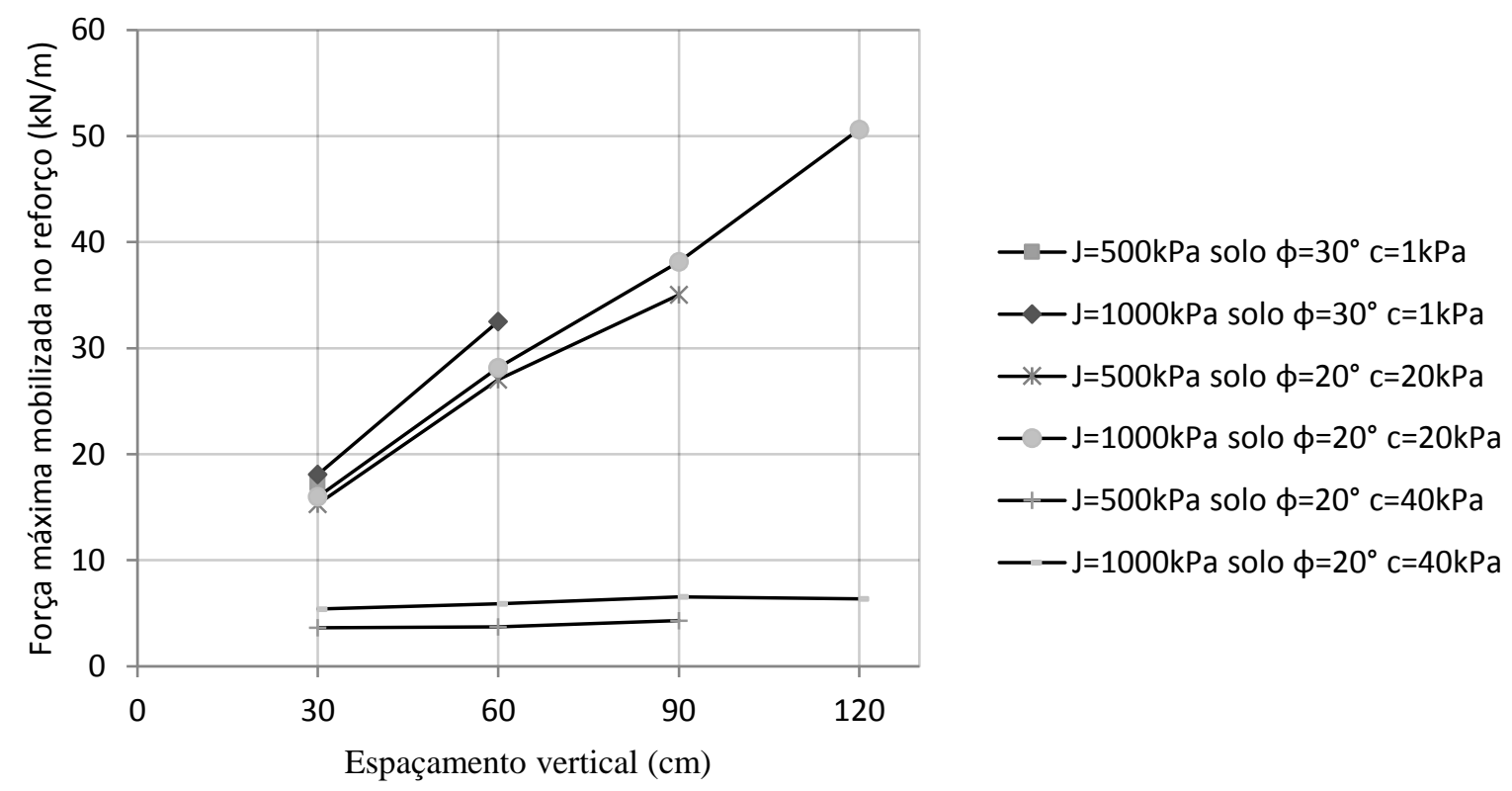

Fonte: Próprio autor

Para solo não coesivo, um muro com a configuração adotada romperia com espaçamentos maiores do que $0,30 \mathrm{~m}$ para $\mathrm{J}=500 \mathrm{kN} / \mathrm{m}$ e maiores do que $0,60 \mathrm{~m}$ para $\mathrm{J}=1000 \mathrm{kN} / \mathrm{m}$. 
Nas demais simulações houve um decréscimo dos deslocamentos com 0 aumento da rigidez do reforço, assim como algumas relações esperadas entre o espaçamento e a rigidez, como o MSRG com $\mathrm{J}=1000 \mathrm{kPa}$ e e=0,60 m ter deslocamentos parecidos aos do MSRG com $\mathrm{J}=500 \mathrm{kPa}$ e e $=0,30 \mathrm{~m}$.

Tanto Ehrlich e Becker (2009) quanto a FHWA-HRT-14-094 (2015) utilizam a relação entre a resistência do reforço e seu espaçamento nos seus métodos de calculo. Seguindo essa lógica as relações $(\mathrm{J} / \mathrm{e})$ apresentadas nesse gráfico deveriam acarretar valores idênticos no deslocamento máximo da face, o que ocorreu apenas em algumas situações. Uma explicação disso é o fato desses métodos simplificarem os mecanismos de distribuição das tensões no interior em relação à rigidez do reforço, e consequentemente as deformações internas. 


\section{CONCLUSÕES}

As principais conclusões deste trabalho sobre a influência da geometria e das combinações de materiais - solo e geossintético - em um muro de solo reforçado com geossintético (MSRG) por meio de modelagem numérica, com base no deslocamento máximo da face do muro, foram:

\subsection{MODELAGEM NUMÉRICA DO MODELO FíSICO ESTUDADO}

- Foi possível calibrar o modelo numérico baseado no modelo físico de MSRG de Portelinha (2012) com o software Plaxis.

- Os resultados da modelagem numérica se aproximaram melhor dos deslocamentos medidos no modelo físico de Portelinha (2012) quando foi simulado o efeito da compactação, por meio da construção por etapas, utilização do modelo constitutivo soil hardening, representação do esforço de compactação por uma carga estática vertical aplicada e imposição de um deslocamento pequeno na base do muro.

- Evidenciou-se a complexidade da interação entre o reforço e o solo. Por exemplo, a influência da rigidez do reforço foi mais importante para os solos CL e ML do que para os solos MH, SM e SC. Para o solo CL o deslocamento máximo na face diminuiu 7 vezes (de $70 \mathrm{~mm}$ para $10 \mathrm{~mm}$ ) quando a rigidez do reforço aumentou 150 vezes (de $11 \mathrm{kN} / \mathrm{m}$ para 1700 $\mathrm{kN} / \mathrm{m}$ ). Para o solo SC, esta redução foi menos importante, de 2,5 vezes (de $5 \mathrm{~mm}$ para $2 \mathrm{~mm}$ ).

- Reforços mais rígidos contribuem mais para a resistência do MSRG, pois mesmo havendo menores deformações internas, as forças mobilizadas pelos reforços mais rígidos foram maiores, solicitando menos o solo.

\subsection{MODELAGEM NUMÉRICA DE MUROS DE SOLOS REFORÇADOS COM GEOSSINTÉTICO (MSRG) COM ALTEAMENTO PROGRESSIVO}

- A complexidade do mecanismo de ruptura do MSRG e da interação entre o geossintético e o solo fez-se notar no estudo de alteamentos sucessivos 
de um MSRG hipotético até $20 \mathrm{~m}$. Foi observado que para um reforço com rigidez de $11 \mathrm{kN} / \mathrm{m}$, o muro atingiria maior altura com o solo $\mathrm{MH}$, enquanto que com rigidez de $100 \mathrm{kN} / \mathrm{m}$, a maior altura seria atingida com o solo CL. Os deslocamentos máximos da face do muro seriam praticamente iguais para muros de mesma altura construídos com os solos MH e SM para qualquer reforço estudado; porém, comparando-se os dois solos e o mesmo reforço, com o solo $\mathrm{MH}$ poderia ser atingida maior altura. Como os parâmetros de resistência e deformabilidade variaram entre os solos investigados, não ficou claro qual é o fator de maior influência.

- Comprovou-se que reforços mais rígidos contribuem mais para a resistência do MSRG. Quando a rigidez do reforço é alta, o tipo de solo influi menos na estabilidade do muro. Por exemplo, com rigidez de 500 $\mathrm{kN} / \mathrm{m}$ (típica de uma geogrelha), os muros simulados não apresentaram ruptura com $20 \mathrm{~m}$ de atura (altura máxima simulada) para qualquer um dos três solos investigados (SM, CL e MH). Por outro lado, mesmo com os reforços mais rígidos ( $1000 \mathrm{kN} / \mathrm{m}$ ), o tipo do solo com que é construído o muro influi nos deslocamentos máximos da face do muro.

- Observou-se que para muros mais baixos, de inclinações suaves e parâmetros de resistência do solo elevados, o módulo de deformabilidade do solo e o deslocamento máximo da face do muro foram inversamente relacionados, sendo que ao se dobrar a rigidez do solo, observou-se metade do deslocamento máximo na face. Por exemplo, nas simulações de MSRG com variação paramétrica sistemática dos materiais (coesão, ângulo de atrito, rigidez), em muros de $5 \mathrm{~m}$ de altura, obtiveram-se deslocamentos aproximados de 6,3 e $1 \mathrm{~mm}$ ao variar o módulo de deformabilidade do solo de 10, 20 e $60 \mathrm{MPa}$, respectivamente.

\subsection{MODELAGEM NUMÉRICA DE MSRG COM ALTURA FIXA DE 10 METROS}

- Observou-se que o ângulo de atrito tem maior relevância no comportamento do MSRG para valores mais baixos de coesão. Por exemplo, ao se fixar a coesão em $20 \mathrm{kPa}$, um aumento do ângulo de 
atrito de $10^{\circ}$ para $20^{\circ}$ resulta na diminuição do deslocamento máximo na face de aproximadamente $150 \mathrm{~mm}$. Para a coesão de $60 \mathrm{kPa}$, por outro lado, a deformada do muro praticamente independe do ângulo de atrito e da rigidez do solo, apresentando valores inferiores a $40 \mathrm{~mm}$ de deslocamento máximo na face para $10 \mathrm{~m}$ de altura.

- Um aumento do ângulo do atrito diminui o deslocamento máximo na face do muro, porém este ganho é mais significativo para baixos valores de coesão e de ângulo de atrito. Retomando o caso da coesão igual a 20 $\mathrm{kPa}$, um aumento do ângulo de atrito de $20^{\circ}$ para 30 resulta na redução de aproximadamente $20 \mathrm{~mm}$ do deslocamento máximo na face.

- Constatou-se que o aumento da inclinação do MSRG sempre acarreta um aumento do deslocamento máximo na face, porém esse aumento depende do solo e reforço utilizado. Por exemplo, para um solo com ângulo de atrito de 20으, coesão de $40 \mathrm{kPa}$ e E=60 MPa, os deslocamentos máximos na face aumentam de 20 para $30 \mathrm{~mm}(50 \%)$ quando a inclinação do muro aumenta de $3 \mathrm{~V}: 1 \mathrm{H}$ para $9 \mathrm{~V}: 1 \mathrm{H}$.

Para um solo com coesão de $20 \mathrm{kPa}$ e E=10 MpaPa, por outro lado, o deslocamento máximo pode aumentar de $120 \mathrm{~mm}$ a $190 \mathrm{~mm}$ para ângulo de atrito de $10^{\circ}$. Com ângulos de atrito superiores a $20^{\circ}$, o deslocamento máximo da face do muro aumenta com a inclinação, mas mantém-se inferior a $50 \mathrm{~mm}$.

- Observou-se que nem sempre a relação do espaçamento vertical com a rigidez do reforço $(\mathrm{J} / \mathrm{e})$ proposto na literatura é verdadeira. As simulações com $\mathrm{J}=1000 \mathrm{KPa}$ e $\mathrm{e}=0,60 \mathrm{~m}$ resultaram em deslocamentos máximos semelhantes às com $\mathrm{J}=500 \mathrm{KPa}$ e $\mathrm{e}=0,30 \mathrm{~m}$, porém, nas demais situações, essa proporcionalidade não foi verificada, dependendo também dos parâmetros do solo. Provavelmente essa relação só ocorre quando os mecanismos de distribuição das tensões no interior não se modificam em função do espaçamento ou da rigidez do reforço. 


\subsection{COMENTÁRIOS FINAIS}

- A modelagem numérica se mostrou uma ferramenta importante para analisar o comportamento de MSRG, o qual depende de uma grande diversidade de parâmetros, que podem ser facilmente variados em simulações numéricas, diferentemente do que ocorre em laboratório ou em ensaios piloto.

- As simulações numéricas corroboraram a bem sucedida prática nacional de construção de MSRG com solos finos tropicais, dados seus parâmetros de resistência e deformabilidade elevados quando compactados.

- A coesão do solo se mostrou um parâmetro de grande relevância no comportamento do MSRG, inclusive a ponto de praticamente o reforço não ser mobilizado em alguns casos estudados de coesão elevada.

- A análise da potêncial superficie de ruptura merece um aprofundamento, pois a máxima solicitação dos reforços no MSRG em condição de trabalho não corresponde a proximidade da ruptura. 


\subsection{SUGESTÕES PARA PROSSEGUIMENTO DA PESQUISA}

- Comparar os resultados obtidos com outras simulações e com soluções análiticas de deslocamento de face e força mobilizada no reforço de MSRG.

- Procurar dados de monitoramento e de investigação de campo para confrontar com resultados de análises numéricas de MSRG.

- Estabelecer critérios para definição da potencial superficie de ruptura, considerando que o local em que encontram-se as maiores mobilizações do reforço na condição de trabalho podem diferir do local em que ocorrerá a ruptura em situação extrema.

- Estudar a distribuição das tensões internas em função das características do MSRG.

- Repetir algumas análises para espaçamentos maiores do reforço, conforme valores utilizados na prática. 


\section{REFERÊNCIAS BIBLIOGRÁFICAS}

ABRAMENTO, M. - Analysis and measurement of stresses in planar soil reinforcements. Tese de Doutorado apresentada no Massachusetts Institute of Technology, 1993.

ABNT. Associação Brasileira de Normas Técnicas. NBR ISO 10318:2013 Geossintéticos - Termos e definições. São Paulo: ABNT, 2013.

Albino, U.R. ; Kuahara, J.; Portelinha, F.H.M.; Marcos M. Futai, M.M. Modelagem numérica da infiltração unidirecional em interfaces não saturadas sologeotêxtil. XVIII Congresso Brasileiro de Mecânica dos Solos e Engenharia Geotécnica, Belo Horizonte, 2016.

AMERICAN ASSOCIATION OF STATE HIGHWAY AND TRANSPORTATION OFFICIALS. Standard specifications for highway bridges, AASHTO, 17th Ed., Washington, D.C, EUA, 2002, 829p.

AZEVEDO, A. FM. - Método dos elementos finitos. Faculdade de Engenharia da Universidade do Porto, 2003. $1 \mathrm{v}$.

BARBOZA JÚNIOR, J. C., Estudo através de Modelos Físicos da Influência da Face e da Compactação em Muros de Solo Reforçado, Dissertação de Mestrado COPPE/UFRJ, Rio de Janeiro, RJ, Brasil, 2003.

BATHE, K. J. Finite Element Procedures in Engineering Analysis. New J. Prentice-Hall, Inc., Englewood Cliffs, 1982.

BENJAMIM, C.V.S. - Avaliação experimental de protótipos de estruturas de contenção em solo reforçado com geotéxil. Tese (Doutorado) - Escola de Engenharia de São Carlos da Universidade de São Paulo, São Carlos, 2006.

BOUAZZA, Abdelmalek et al. Unsaturated Geotechnics Applied To Geoenvironmental Engineering Problems Involving Geosynthetics. Engineering Geology, 165 v, p. 143-153, 2013. 
BRINKGREVE, R.B.J.; VERMEER P.A. Plaxis Manual Version 7. Balkema, Rotterdam, 1998.

BRITISH STANDARDS INSTITURION. BS 8006. Code Of Practice For Strengthened/Reinforced Soils And Other Fill. British Standard Institution, 1995.

CARLOS, David Miranda; PINHO-LOPES, Margarida; LOPES, Maria Lurdes. Effect of Geosynthetic Reinforcement Inclusion on the Strength Parameters and Bearing Ratio of a Fine Soil. Procedia Engineering, v. 143, p. 34-41, 2016.

CARVALHO, P. A. S.; PEDROSA, J. A. B. A.; WOLLE, C. M. Aterro reforçado com geotêxteis - uma opção alternativa para a engenharia geotécnica. VIII Congresso Brasileiro de Mecânica dos Solos e Engenharia de Fundações. 6 v, p. $169-178,1986$.

CECÍLIO JR, O. - Estudo do comportamento de um túnel em solo residual de gnaisse por meio de ensaios triaxiais com controle de trajetórias de tensões. Dissertação de Mestrado. Universidade de São Paulo, 2009.

CRUZ, Paulo Teixeira da. 100 barragens brasileiras: casos históricos, materiais de construção, projeto. Oficina de Textos, 1996.

DANTAS, B. T.; EHRLICH, M. Performance of geosynthetic reinforced slopes at failure. Journal of Geotechnical and Geoenvironmental Engineering, ASCE, v. 126, n. 3, p. 286-288, 2000.

EHRLICH, Maurício. Deformação em muros de solos reforçados. $2^{\circ}$ Simpósio Brasileiro sobre aplicações de geossintéticos, São Paulo, p. 31-42, 1995.

EHRLICH, M.; AZAMBUJA, E. Muros de solo reforçado. IV SIMPÓSIO BRASILEIRO DE GEOSSINTÉTICOS. Porto Alegre, p. 81-100, 2003.

EHRLICH, M., MITCHELL, J.K. - Working stress design method for reinforced soil walls. J. Geotech. Eng. ASCE 120 (4), p. 625-645, 1994.

EHRLICH, M.; BECKER, L. Muros e taludes de solo reforçado: projeto e execução. São Paulo: Oficina de Textos, 2009. 
EHRLICH, M.; MIRMORADI, S. H.; SARAMAGO, R. P. Evaluation of the effect of compaction on the behavior of geosynthetic-reinforced soil walls. Geotêxtiles and Geomembranes, v. 34, p. 108-115, 2012.

EHRLICH, M.; MIRMORADI, S. H. Evaluation of the effects of facing stiffness and toe resistance on the behavior of GRS walls. Geotêxtiles and Geomembranes, v. 40, p. 28-36, 2013.

FARRAG, K; ACAR, Y. B.; JURAN, I. Pullout resistance of geogrid reinforcements. Geotêxtiles and Geomembranes, v. 12, p.133-159, 1993.

FEDERAL HIGHWAY ADMINISTRATION. FHWA 1998. Mechanically stabilized earth walls and reinforced soil slopes design and construction guidelines. FHWA-SA96-071, Elias, V.; Christopher, B.R., 1998, Washington, DC, September, 371p.

FEDERAL HIGHWAY ADMINISTRATION. FHWA-HRT-14-094: Synthesis of Geosynthetic Reinforced Soil Design Topics. Hawaí, EUA, 2015. 77p.

GUEDES, V. C. P., Estudo da Influência da Compactação, do Tipo e Inclinação da Face no Comportamento de Muros de Solo Reforçado, Dissertação de Mestrado, COPPE/UFRJ, Rio de Janeiro, RJ, Brasil, 2004

GULER, E.; HAMDERI, M.; DEMIRKAN, M. M. - Numerical analysis of reinforced soil-retaining wall structures with cohesive and granular backfills. Geosynthetics International, 2007.

HATAMI, Kianoosh; BATHURST, Richard J. Numerical model for reinforced soil segmental walls under surcharge loading. Journal of Geotechnical and Geoenvironmental Engineering, v. 132, n. 6, p. 673-684, 2006.

HELWANY, S. M. B.; REARDON, G.; WU, J. T. H. Effects of backfill on the performance of GRS retaining walls. Geotêxtiles and Geomembranes, v. 17, n. 1, p. $1-16,1999$

$\mathrm{HO}$, See Keung. A numerical investigation into the behaviour of reinforced soil walls. Tese de doutorado, Universidade do oeste de Ontario, Londres, UK, 1993. 
IRYO, T.; ROWE, R. K. - Hydraulic behaviour of soil-geocomposite layers in slopes. Geosynthetics International, v. 12, n. 3, p. 145-155, 2005.

JEWELL, R. A., 1990, Strength and deformation in reinforced soil design. In: Proc. 4th International Conference on Geotêxtiles, Geomembranes and Related Products, v. 3, pp. 913-946, The Hague.

LAJEVARDI, S. H.; BRIANÇON, L.; DIAS, D. Experimental studies of the geosynthetic anchorage-Effect of geometric parameters and efficiency of anchorages. Geotêxtiles and Geomembranes, v. 42, n. 5, p. 505-514, 2014.

LIMA, M. J.; PALMEIRA, E. M.; ZORNBERG, J. G. - Determinação de curva de retenção de água de geotêxtil não tecido utilizando ensaio de coluna suspensa. Cobramseg, Goiânia/GO, 2014.

LIN, Bo-Hung et al. Deterministic and probabilistic prediction of facing deformations of geosynthetic-reinforced MSE walls using a response surface approach. Geotextiles and Geomembranes, v. 44, n. 6, p. 813-823, 2016.

KAKUDA, F. M. - Estudo de ensaios de arrancamento de geogrelha com utilização de um equipamento reduzido. Dissertação de Mestrado. Universidade de São Paulo, 2005.

KARPURAPU, Rajagopal; BATHURST, Richard J. Behaviour of geosynthetic reinforced soil retaining walls using the finite element method. Computers and Geotechnics, v. 17, n. 3, p. 279-299, 1995.

KOERNER, R. Designing with geosynthetics. Englewood Cliffs, New Jersey, Prentice Hall, 4⿳亠丷厂 edição, 1994.

KOERNER, Robert M.; KOERNER, George R. A data base, statistics and recommendations regarding 171 failed geosynthetic reinforced mechanically stabilized earth (MSE) walls. Geotextiles and Geomembranes, v. 40, p. 20-27, 2013. 
MIRMORADI, S. H.; EHRLICH, M. - Modeling of the compaction-induced stresses in numerical analyses of GRS walls. International Journal of Computational Methods, v. 11, n. 02, 2014.

MIRMORADI, S. H.; EHRLICH, M.; DIEGUEZ, C. Evaluation of the combined effect of toe resistance and facing inclination on the behavior of GRS walls. Geotextiles and Geomembranes, v. 44, n. 3, p. 287-294, 2016.

NOGAMI, J.S.; VILLIBOR, D.F. Pavimentação de baixo custo com solos lateríticos. São Paulo, ed. Villibor, 1995.

NOORZAD, R.; MIRMORADI, S. H. Laboratory evaluation of the behavior of a geotextile reinforced clay. Geotextiles and Geomembranes, v. 28, n. 4, p. 386-392, 2010.

O' KELLY B. C.; NAUGHTON,P. J. On the interface shear resistance of a novel geogrid with in-plane drainage capability. Geotextiles and Geomembranes, v. 26, p. 357-362, 2008.

OLIVEIRA, Glauco Aguilar. Influência da Rigidez do Reforço em Muros de Solo Reforçado em Modelos Físicos. Dissertação de Mestrado. UNIVERSIDADE FEDERAL DO RIO DE JANEIRO, 2006.

PALMEIRA, Ennio Marques. Soil-geosynthetic interaction: Modelling and analysis. GeotêxtilesandGeomembranes, v. 27, n. 5, p. 368-390, 2009

PARK, Kevin D. Evaluation of a geosynthetic capillary break. Tese de Doutorado. University of Saskatchewan, 2005.

PLAXIS - Manual Plaxis 2D-version 8, 2002.

PEDROSO, E.O. Estruturas de contenção reforçadas com geossintéticos. Dissertação de mestrado. Escola de Engenharia de São Carlos da Universidade de São Paulo, São Carlos, 2000.

PEDROSO, E. O. ; BUENO, B. S. ; BENJAMIN, C. V. ; ZORNBERG, J. G. . Field monitoring and numerical prediction of the response of a non-woven 
geotêxtile-reinforced wall. In: 8th International Conference on Geosynthetics, Yokohama, Japan, 2006.

PORTELINHA, F. H. M. - Avaliação experimental da influência do avanço do umedecimento no comportamento de muros de solos finos reforçados com Geotêxteis não tecidos. Tese de Doutorado. Universidade de São Paulo, 2012.

REBELO, Karla Maria Wingler. Resistência de Interface entre geomembranas e solos através do ensaio de Ring Shear. Dissertação de mestrado. Universidade de São Paulo, 2003.

RICCIO, M.; EHRLICH, M.; DIAS, D. - Field monitoring and analyses of the response of a block-faced geogrid wall using fine-grained tropical soils. Geotêxtiles and Geomembranes, v. 42, n. 2, p. 127-138, 2014.

ROWE, R. Kerry; SKINNER, Graeme D. Numerical analysis of geosynthetic reinforced retaining wall constructed on a layered soil foundation. Geotêxtiles and Geomembranes, v. 19, n. 7, p. 387-412, 2001.

SARAMAGO, R. P. Estudo da influência da compactação no comportamento de muros de solo reforçado com a utilização de modelos físicos. 2002. Tese de Doutorado. Tese de doutorado. Universidade Federal do Rio de Janeiro-COPPE, 2002.

SAWICKI, Andrzej. Creep of geosynthetic reinforced soil retaining walls. Geotêxtiles and Geomembranes, v. 17, n. 1, p. 51-65, 1999.

TEIXEIRA, C. F. - Análise Numérica de Ensaios em Solo Reforçado com Geogrelha. Dissertação de mestrado em Engenharia Civil, Pontifícia Universidade Católica do Rio de Janeiro, 2006.

TEIXEIRA, S. H. C. (2003). Estudo da Interação solo-geogrelha em testes de arrancamento e a sua aplicação na análise e dimensionamento de maciços reforçados. São Carlos, 214p. Tese de Doutorado, Escola de Engenharia de São Carlos - Universidade de São Paulo, 2003. 
TRAN, V. D. H.; MEGUID, M. A.; CHOUINARD, L. E. A finite-discrete element framework for the 3D modeling of geogrid-soil interaction under pullout loading conditions. Geotêxtiles and Geomembranes, v. 37, p. 1-9, 2013.

VASCONCELOS, Silvana Macêdo de. Influência de Carregamentos Externos nas Tensões e Deformações de Muros de Solo Reforçado. Dissertação de mestrado Universidade Federal do Rio de Janeiro, 2010.

VERTEMATTI, J. C. Manual Brasileiro de Geossintéticos. Blucher, 2. ed., São Paulo, 2015.

XUE, Jian-Feng et al. Instability of a geogrid reinforced soil wall on thick soft Shanghai clay with prefabricated vertical drains: A case study. Geotêxtiles and Geomembranes, v. 42, n. 4, p. 302-311, 2014.

YANG, G.; DING, J.; ZHOU, Q.; ZHANG, B. - Field behavior of a geogrid reinforced soil retaining wall with a wrap-around facing. ASTM geotechnical testing journal, v. 33, n. 1, p. 96-101, 2010.

YOO, C.; JUNG, H. - Case history of geosynthetic reinforced segmental retaining wall failure. Journal of geotechnical and geoenvironmental engineering, v. 132, n. 12, p. 1538-1548, 2006.

YU, Yan; DAMIANS, Ivan P.; BATHURST, Richard J. Influence of choice of FLAC and PLAXIS interface models on reinforced soil-structure interactions.Computers and Geotechnics, v. 65, p. 164-174, 2015

ZORNBERG, J. G.; LESHCHINSKY, D. Comparison of international design criteria for geosynthetic-reinforced soil structures. Landmarks in Earth Reinforcement, v. 2, p. 1095-1106, 2003. 


\section{APÊNDICE A1}

Foram feitas preliminarmente simulações de solos hipotéticos sem coesão e com baixa coesão, variando-se a rigidez do reforço (10 a $1.000 \mathrm{kN} / \mathrm{m}$ ), As simulações foram de um muro com alteamento sucessivo, de altura variando de zero a $20 \mathrm{~m}$, inclinação da face 3V:1H e 9V:1H, espaçamento entre reforços de $30 \mathrm{~cm}$ e de 60 $\mathrm{cm}$. Os parâmetros dos solos sem coesão e com baixa coesão estão apresentados na Tabela A.1 respectivamente como "granular" e "coesivo".

Tabela A.1 - Parâmetros dos solos tropicais utilizados nas simulações

\begin{tabular}{|c|c|c|c|c|c|}
\hline Solo & $\begin{array}{c}\gamma \\
\left(k N / m^{3}\right)\end{array}$ & $E(\mathrm{kPa})$ & $v$ & $\begin{array}{c}\mathrm{C} \\
(\mathrm{kPa})\end{array}$ & $\varphi\left(^{\circ}\right)$ \\
\hline granular & 20 & 30.000 & 0,3 & 1 & 30 \\
\hline coesivo & 20 & 30.000 & 0,3 & 20 & 20 \\
\hline alta coesão & 40 & 30.000 & 0,3 & 40 & 20 \\
\hline
\end{tabular}

A Figura A.1 e Figura A.2 mostram respectivamente os deslocamentos horizontais máximos e força mobilizada no reforço para o MSRG construído com solo granular, para rigidez do reforço de $10 \mathrm{kN} / \mathrm{m}$ (rigidez típica de um geotêxtil não tecido).

Figura A.1- Deslocamento horizontal máximo na face do MSRG construído com solo granular e reforço de $10 \mathrm{kN} / \mathrm{m}$

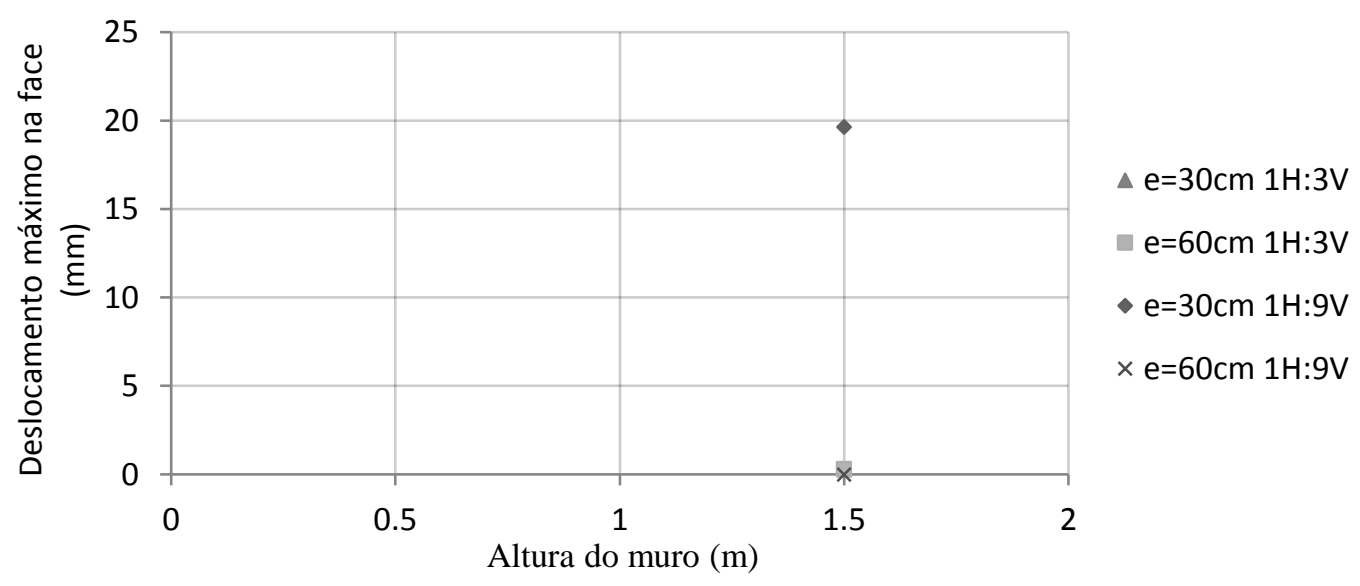

Fonte: Próprio autor 
Figura A.2 - Força máxima mobilizada no reforço do MSRG construído com solo granular e reforço de $10 \mathrm{kN} / \mathrm{m}$

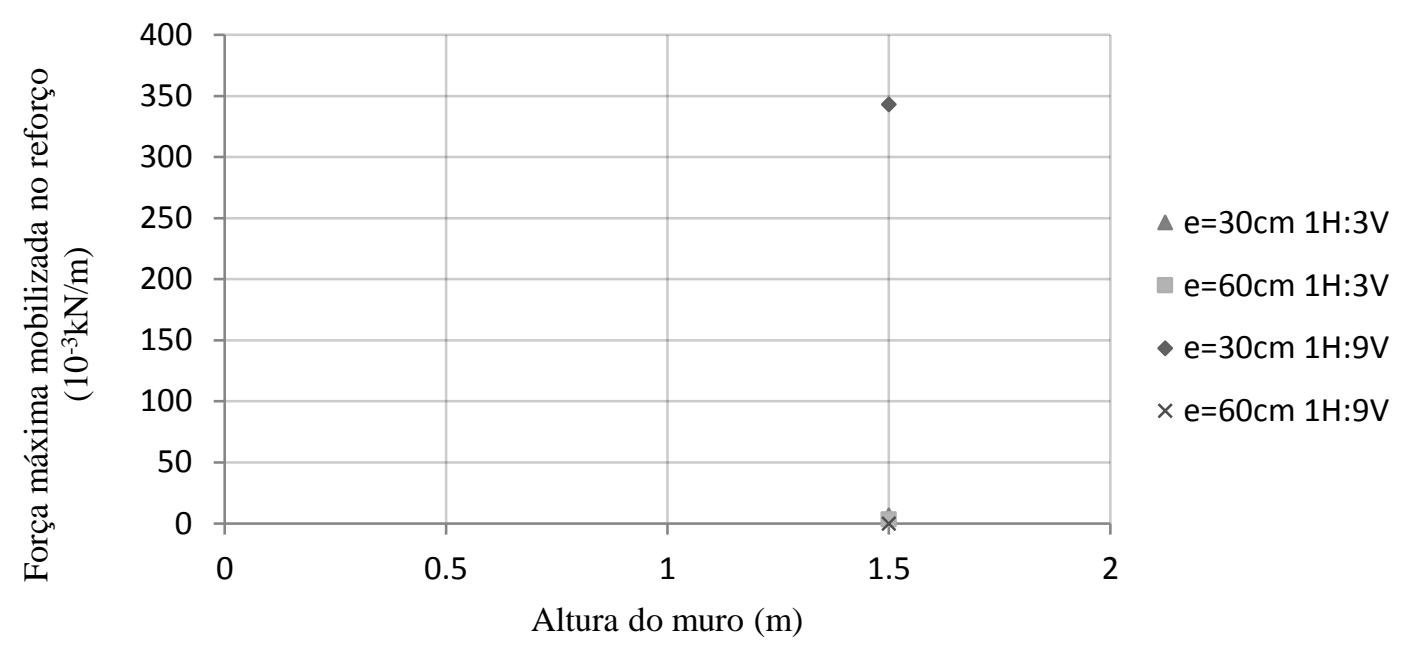

Fonte: Próprio autor

A Figura A.3 e Figura A.4 mostram respectivamente os deslocamentos horizontais máximos e força mobilizada no reforço para o MSRG construído com solo coesivo, para rigidez do reforço de $10 \mathrm{kN} / \mathrm{m}$ (rigidez típica de um geotêxtil não tecido).

Figura A.3 - Deslocamento horizontal máximo na face do MSRG construído com solo coesivo e reforço de $10 \mathrm{kN} / \mathrm{m}$

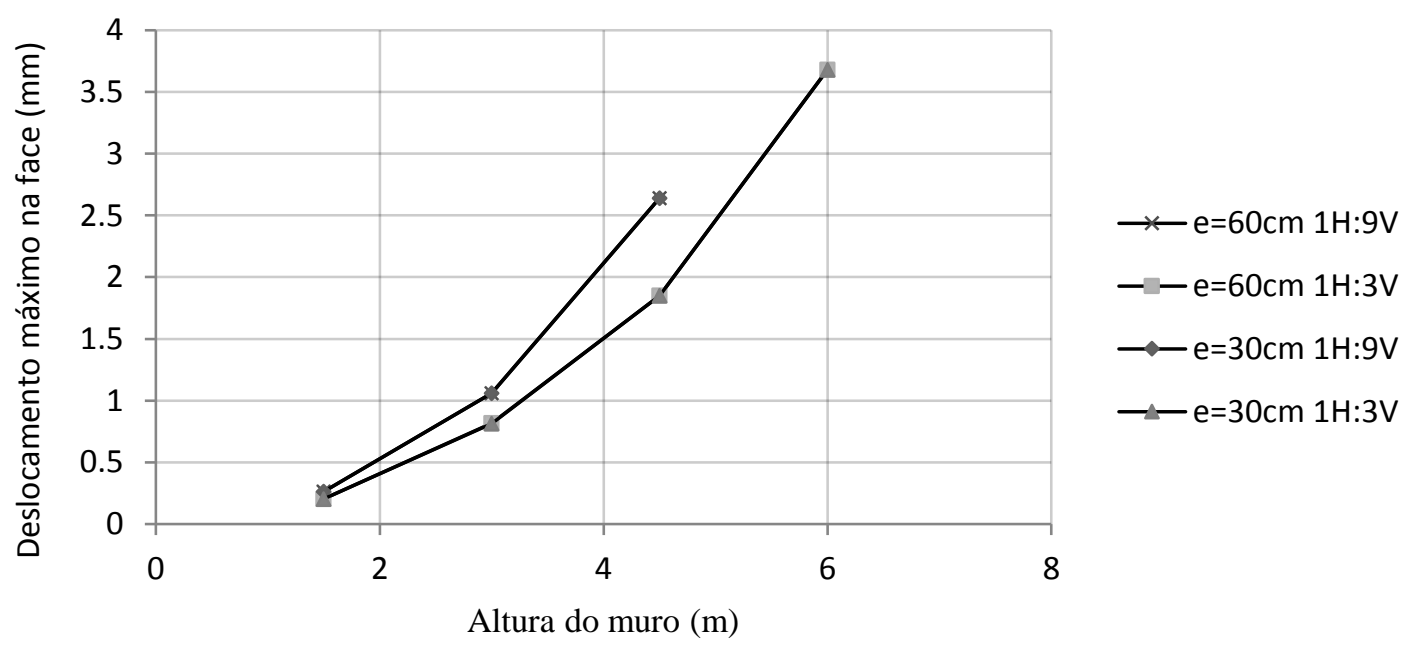

Fonte: Próprio autor 
Figura A.4 - Força máxima mobilizada no reforço do MSRG construído com solo coesivo e reforço de $10 \mathrm{kN} / \mathrm{m}$

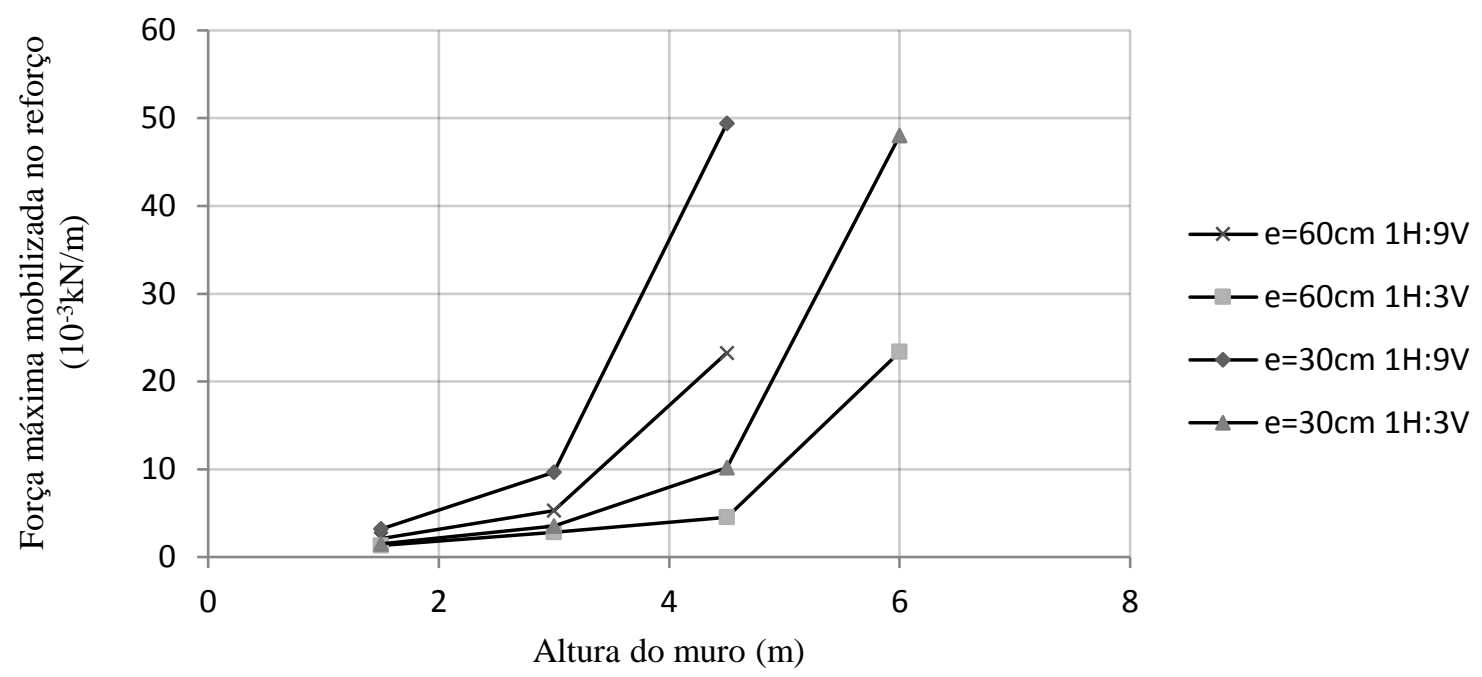

Fonte: Próprio autor

A Figura A.5 e Figura A.6 mostram respectivamente os deslocamentos horizontais máximos e força mobilizada no reforço para o MSRG construído com solo granular e rigidez do reforço de $100 \mathrm{kN} / \mathrm{m}$ (rigidez típica de um geotêxtil tecido).

Figura A.5 - Deslocamento horizontal máximo na face do MSRG construído com solo granular e reforço de $100 \mathrm{kN} / \mathrm{m}$

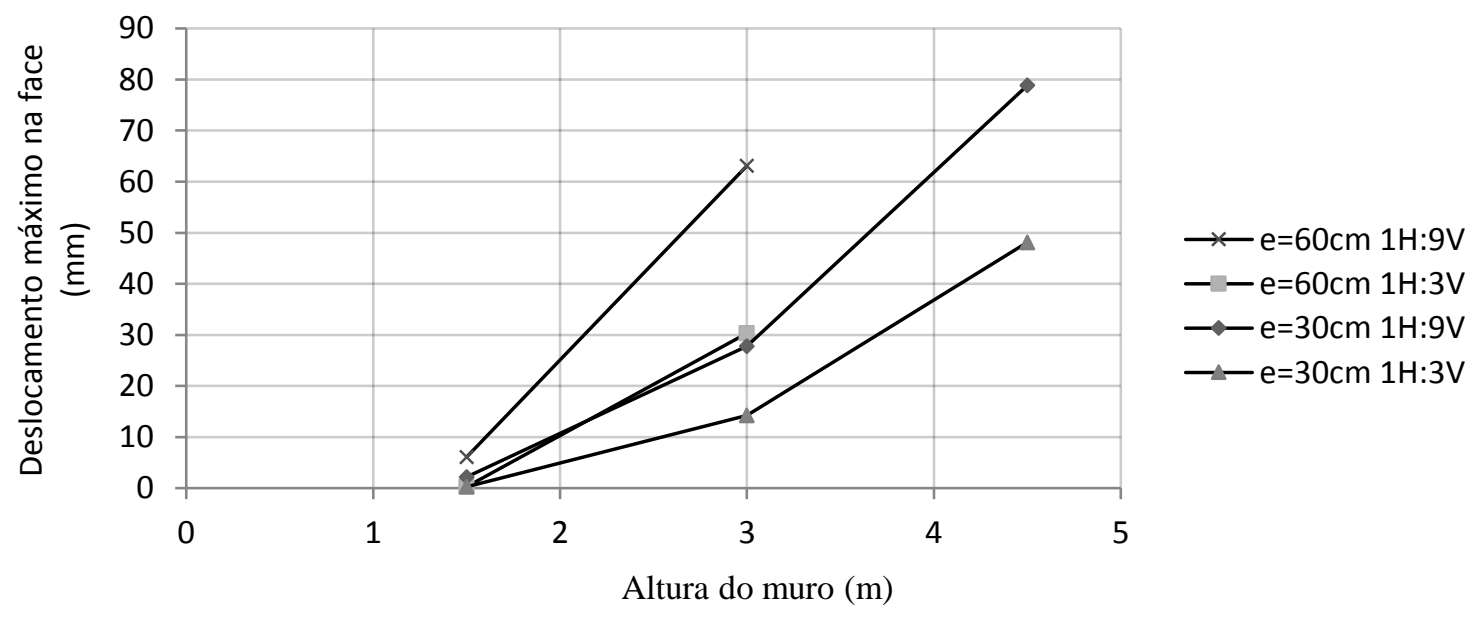

Fonte: Próprio autor 
Figura A.6 - Força máxima mobilizada no reforço do MSRG construído com solo granular e reforço de $100 \mathrm{kN} / \mathrm{m}$

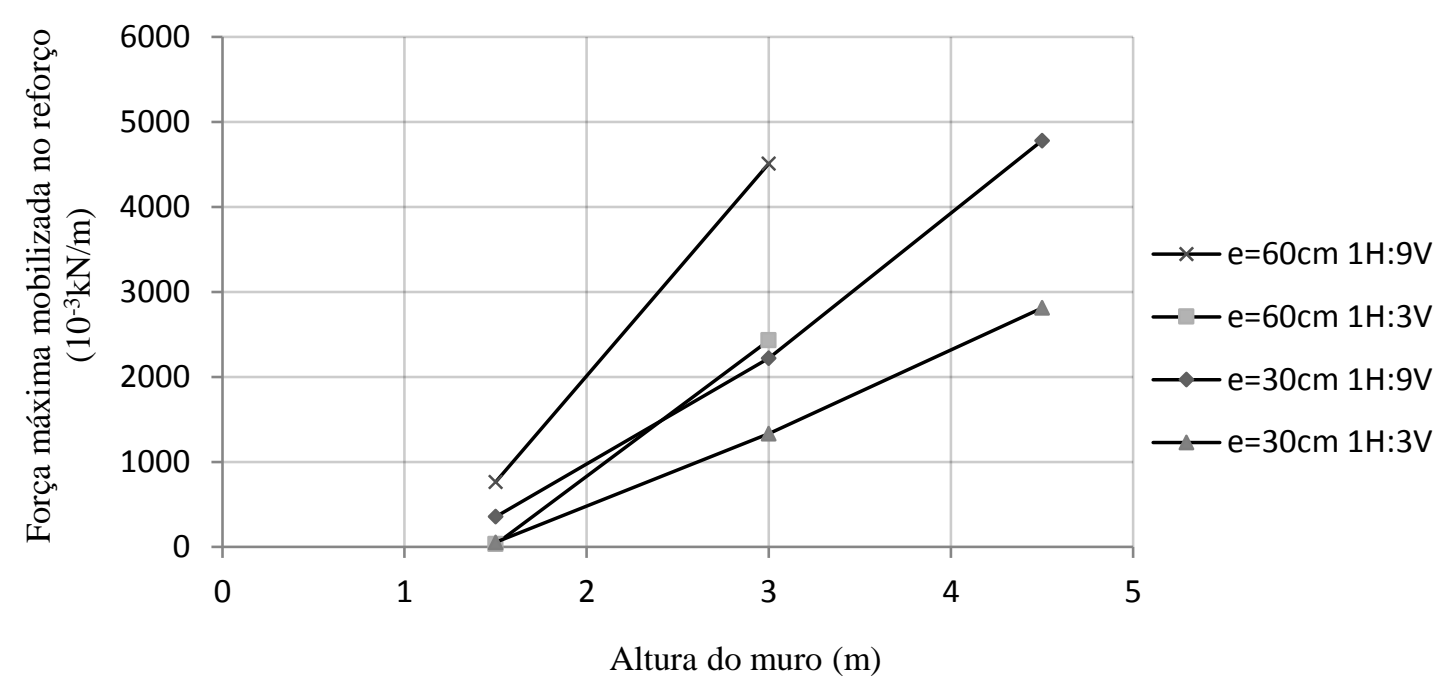

Fonte: Próprio autor

Nas Figura A.7 e Figura A.8 observa-se o comportamento ao se utilizar o solo com coesão, mostrando respectivamente os deslocamentos horizontais máximos e força mobilizada no reforço para o MSRG com rigidez do reforço de $100 \mathrm{kN} / \mathrm{m}$.

Figura A.7 - Deslocamento horizontal máximo na face do MSRG construído com solo coesivo e reforço de $100 \mathrm{kN} / \mathrm{m}$

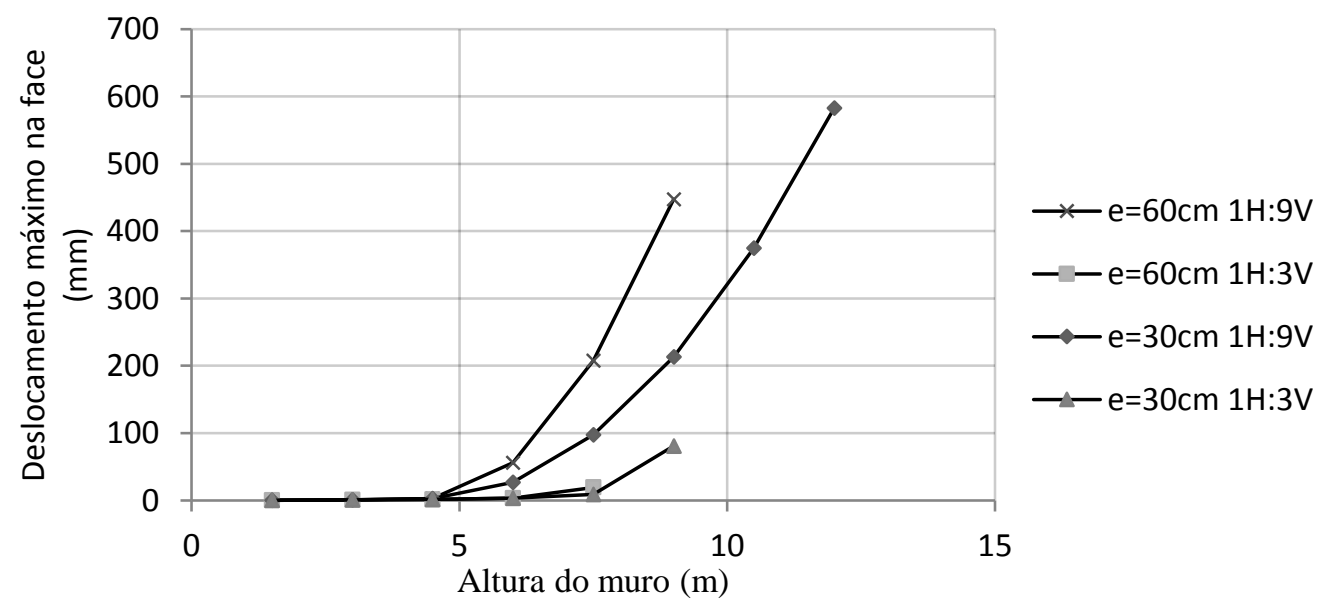

Fonte: Próprio autor 
Figura A.8 - Força máxima mobilizada no reforço do MSRG construído com solo coesivo e reforço de $100 \mathrm{kN} / \mathrm{m}$

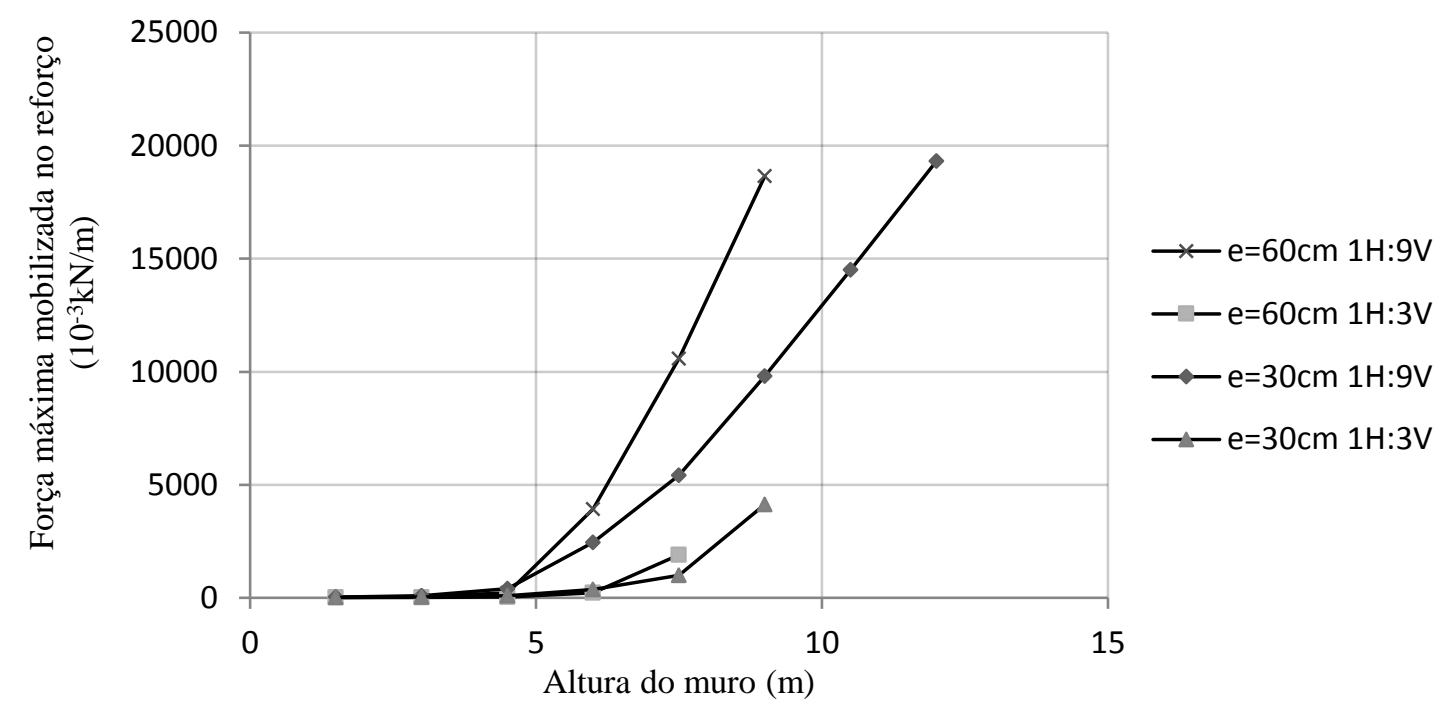

Fonte: Próprio autor

A Figura A.9 e Figura A.10 mostram respectivamente os deslocamentos horizontais máximos e força mobilizada no reforço para o MSRG construído com solo granular e rigidez do reforço de $500 \mathrm{kN} / \mathrm{m}$ (rigidez típica de uma geogrelha).

Figura A.9 - Deslocamento horizontal máximo na face do MSRG construído com solo granular e reforço de $500 \mathrm{kN} / \mathrm{m}$

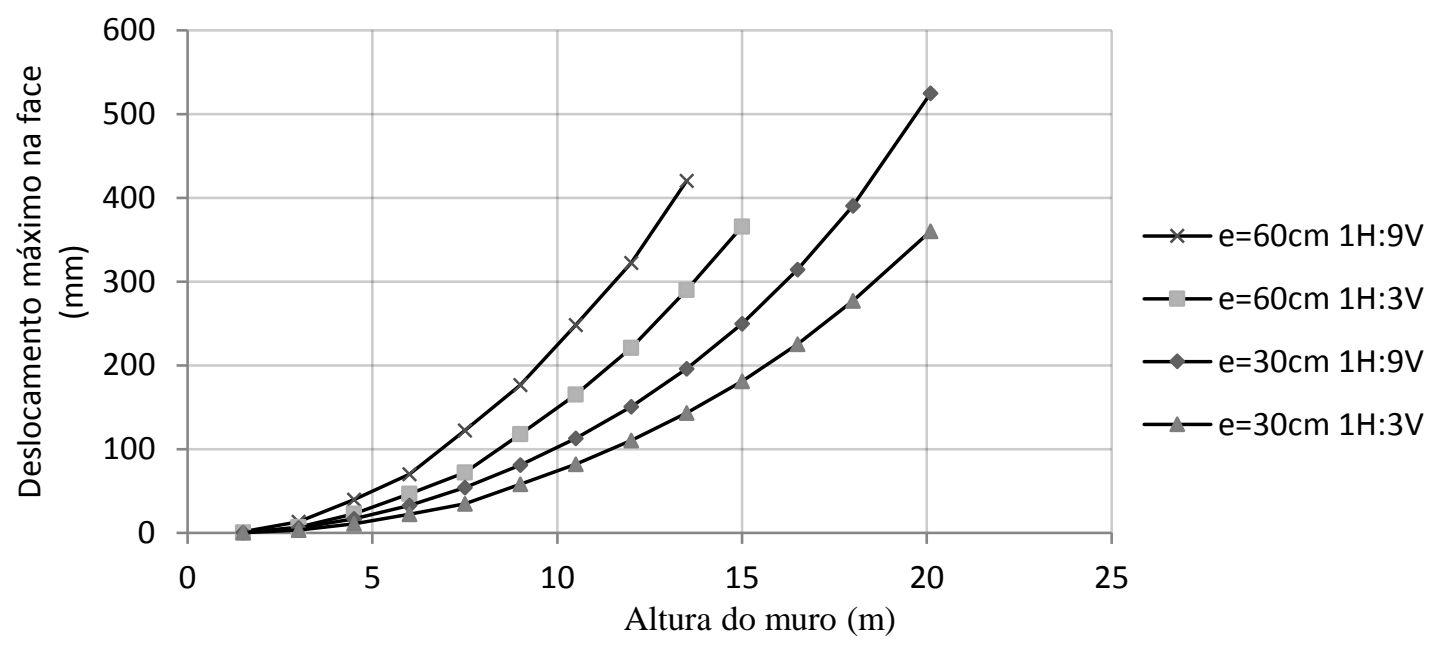

Fonte: Próprio autor 
Figura A.10 - Força máxima mobilizada no reforço do MSRG construído com solo granular e reforço de $500 \mathrm{kN} / \mathrm{m}$

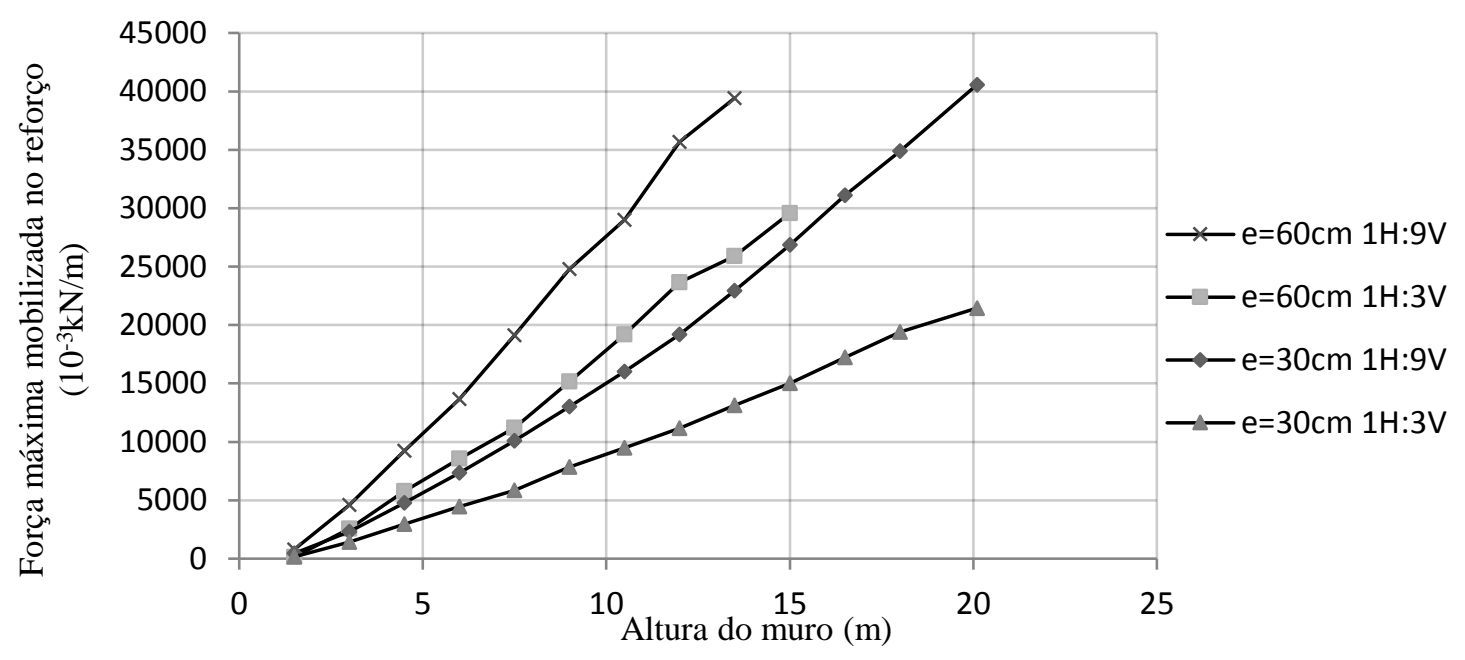

Fonte: Próprio autor

Nas Figura A.11 e Figura A.12 observa-se o comportamento ao se utilizar o solo com coesão, mostrando respectivamente os deslocamentos horizontais máximos e força mobilizada no reforço para o MSRG com rigidez do reforço de $500 \mathrm{kN} / \mathrm{m}$.

Figura A.11 - Deslocamento horizontal máximo na face do MSRG construído com solo coesivo e reforço de $500 \mathrm{kN} / \mathrm{m}$

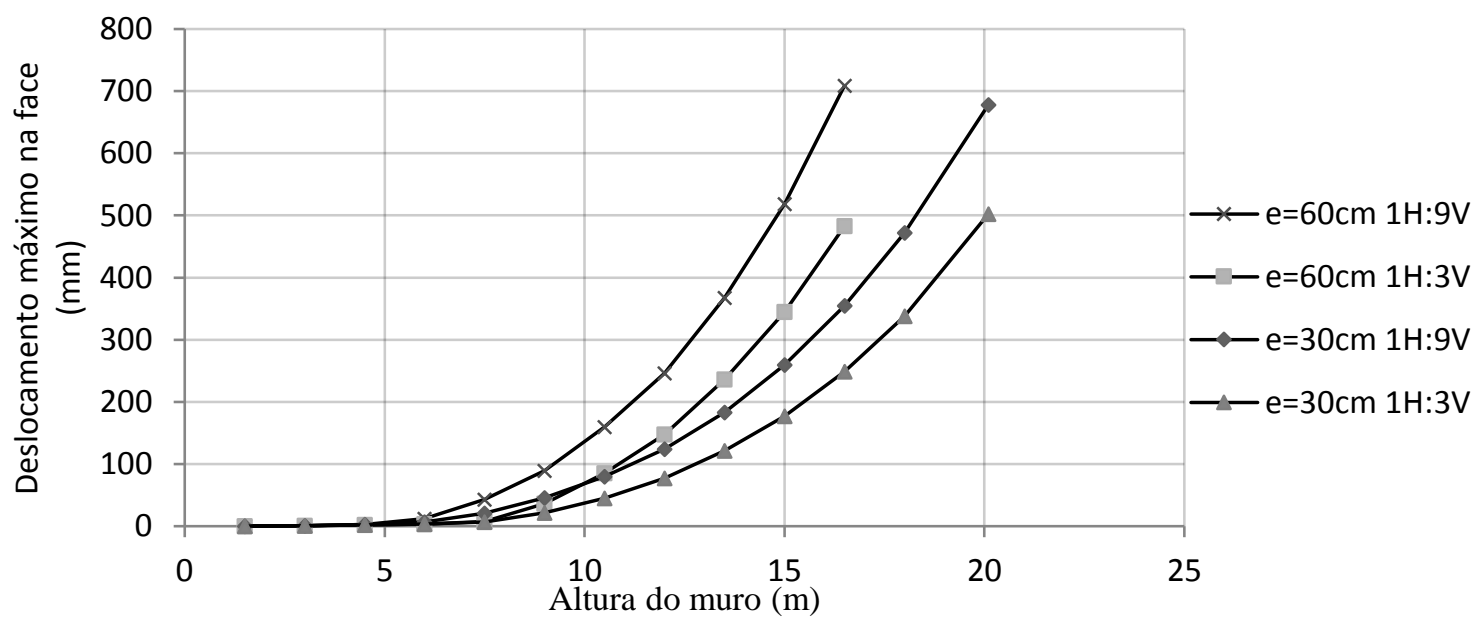

Fonte: Próprio autor 
Figura A.12 - Força máxima mobilizada no reforço do MSRG construído com solo coesivo e reforço de $500 \mathrm{kN} / \mathrm{m}$

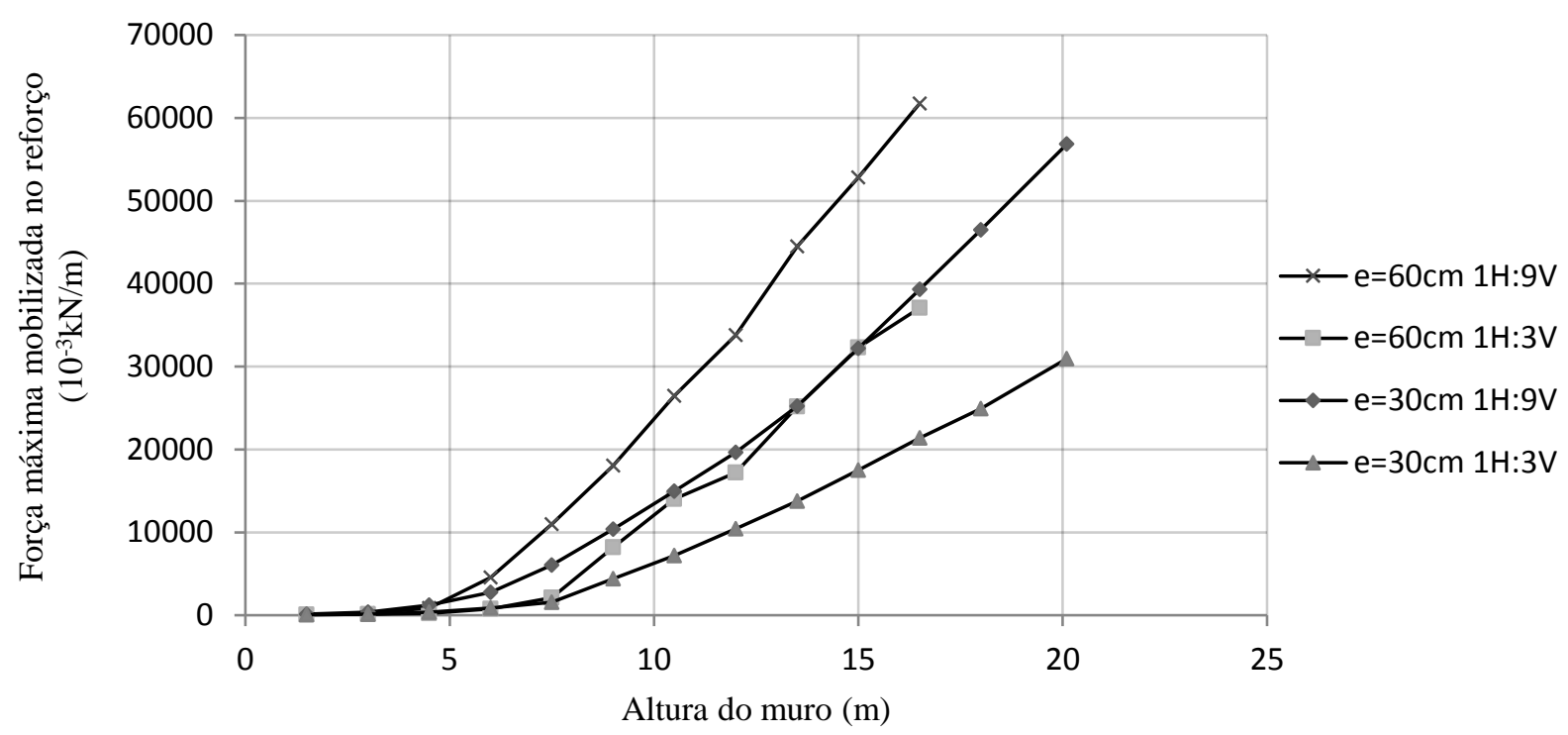

Fonte: Próprio autor

A Figura A.13 e Figura A.14 mostram respectivamente os deslocamentos horizontais máximos e força mobilizada no reforço para o MSRG construído com solo granular e rigidez do reforço de $1.000 \mathrm{kN} / \mathrm{m}$ (rigidez representando uma geogrelha mais resistente).

Figura A.13 - Deslocamento horizontal máximo na face do MSRG construído com solo granular e reforço de $1.000 \mathrm{kN} / \mathrm{m}$

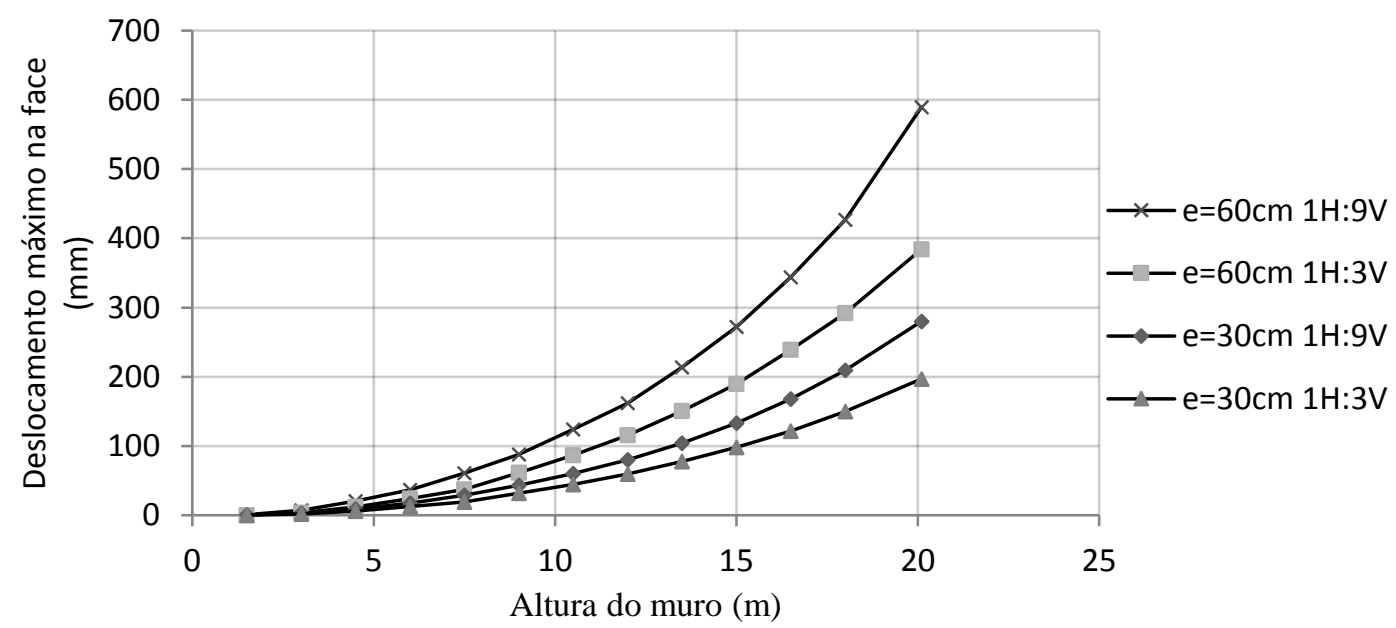

Fonte: Próprio autor 
Figura A.14 - Força máxima mobilizada no reforço do MSRG construído com solo granular e reforço de $1.000 \mathrm{kN} / \mathrm{m}$

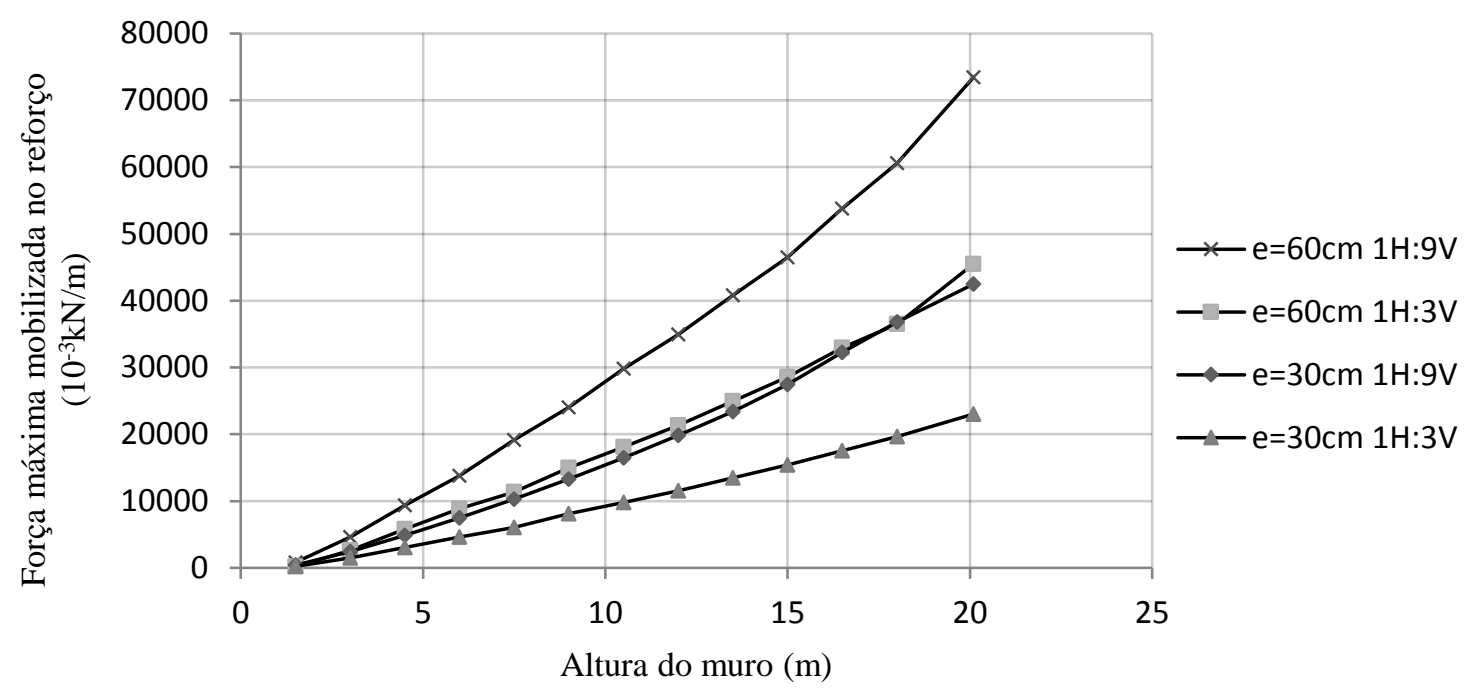

Fonte: Próprio autor

Nas Figura A.15 e Figura A.16 observa-se o comportamento ao se utilizar o solo com coesão, mostrando respectivamente os deslocamentos horizontais máximos e força mobilizada no reforço para o MSRG com rigidez do reforço de $1.000 \mathrm{kN} / \mathrm{m}$.

Figura A.15 - Deslocamento horizontal máximo na face do MSRG construído com solo coesivo e reforço de $1.000 \mathrm{kN} / \mathrm{m}$

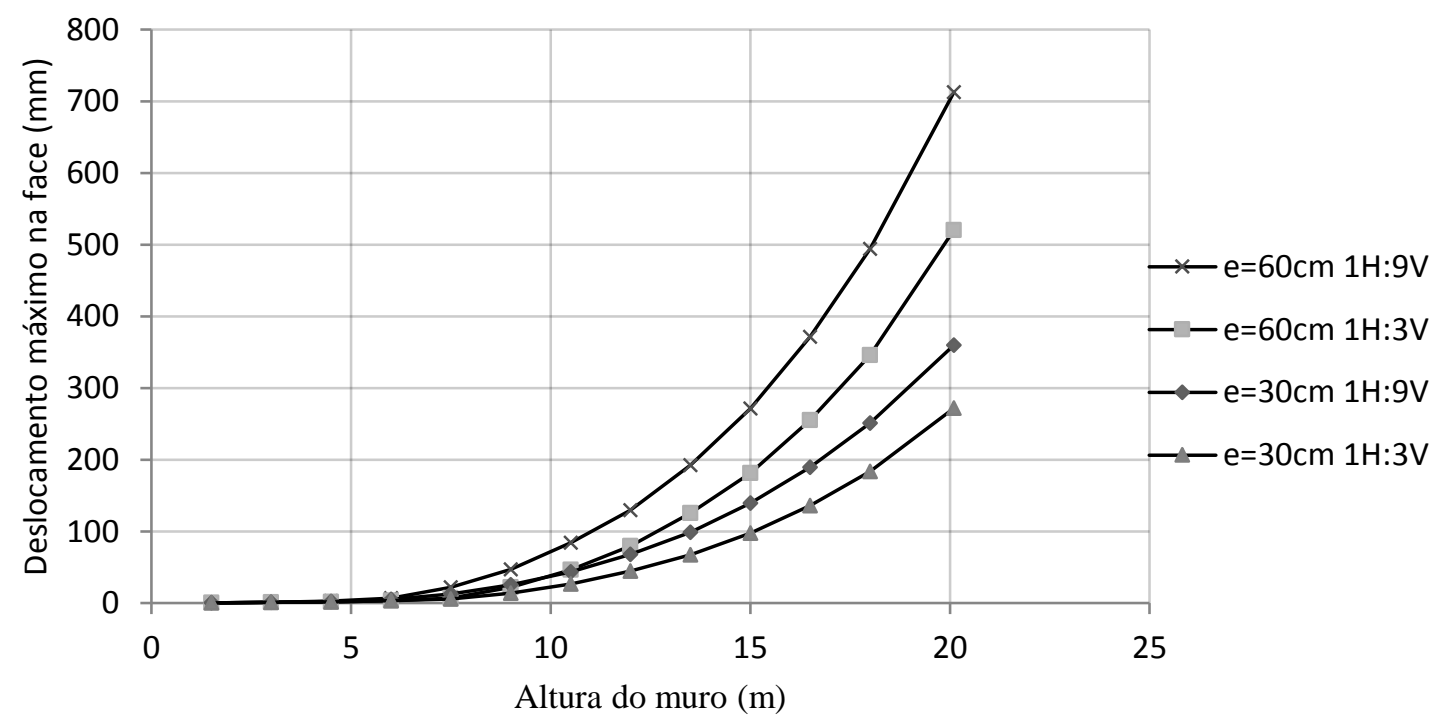

Fonte: Próprio autor 
Figura A.16 - Força máxima mobilizada no reforço do MSRG construído com solo coesivo e reforço de $1.000 \mathrm{kN} / \mathrm{m}$

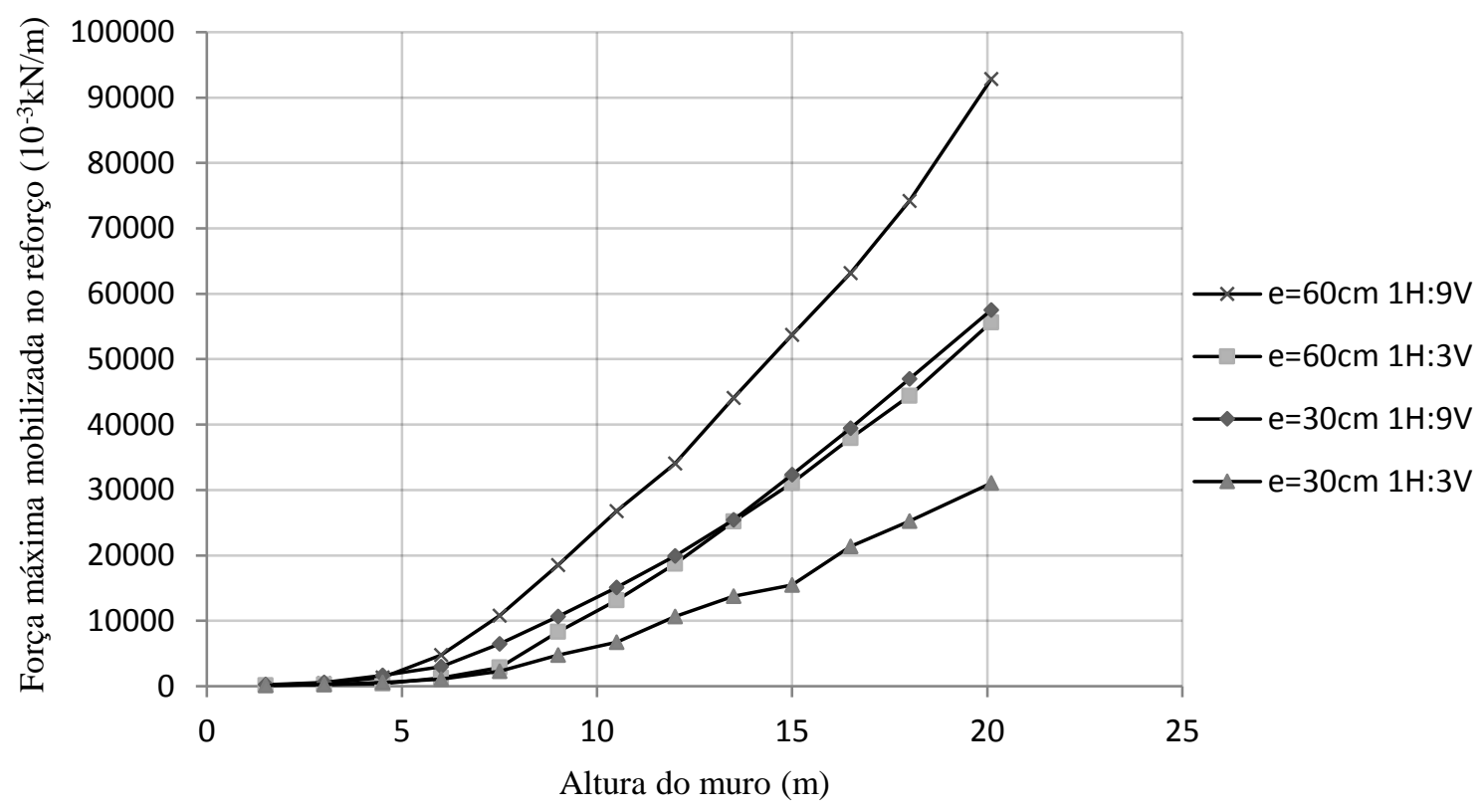

Fonte: Próprio autor

Nesta etapa ficou evidente que para muros de maior altura fica complexa a análise da combinação da rigidez do reforço com os parâmetros de resistência e rigidez do solo: nas simulações, muros com reforço rígido atingiram a altura de $20 \mathrm{~m}$ sem romper independentemente do solo de reaterro, enquanto o comportamento de muros com reforços de menor rigidez dependiam mais do tipo de solo, podendo apresentar ruptura em alturas inferiores a $20 \mathrm{~m}$. 


\section{APÊNDICE A2}

Um resumo das simulações realizadas está apresentado na Tabela A2.

Tabela A.2 - Variação dos parâmetros nas simulações realizadas

\begin{tabular}{|c|c|c|c|c|c|c|}
\hline $\begin{array}{c}\text { Simula- } \\
\text { ção }\end{array}$ & $\begin{array}{c}\text { Tipo de } \\
\text { modelagem }\end{array}$ & $\begin{array}{l}\text { Peculia- } \\
\text { ridade } \\
\text { simulada }\end{array}$ & Solo & $\begin{array}{l}\text { Rigi- } \\
\text { dez do } \\
\text { reforço } \\
\text { (kN/m) }\end{array}$ & $\begin{array}{l}\text { Incli- } \\
\text { nação } \\
\text { da face }\end{array}$ & Observação \\
\hline CALI 1 & MODELO FíSICO & $\begin{array}{c}\text { Mohr } \\
\text { Coulomb } \\
\text { (MC) }\end{array}$ & solo 1 & 11 & $90^{\circ}$ & - \\
\hline CALI 2 & MODELO FÍSICO & $\begin{array}{c}\text { Hardening } \\
\text { Soil Model } \\
\text { (HS) + } \\
\text { compacta- } \\
\text { ção (COM) }\end{array}$ & solo 1 & 11 & $90^{\circ}$ & - \\
\hline CALI 3 & MODELO FíSICO & $\begin{array}{c}\mathrm{HS}+ \\
\text { imprecisão } \\
\text { da } 1 \text { a fôrma }\end{array}$ & solo 1 & 11 & $90^{\circ}$ & - \\
\hline MF1 & MODELO FÍSICO & $\begin{array}{c}\text { HS com } \\
\text { compacta- } \\
\text { ção (COM) }\end{array}$ & solo 1 & 11 & $90^{\circ}$ & - \\
\hline MF2 & MODELO FíSICO & $\mathrm{HS}+\mathrm{COM}$ & solo 1 & 100 & $90^{\circ}$ & - \\
\hline MF3 & MODELO FÍSICO & $\mathrm{HS}+\mathrm{COM}$ & solo 1 & 750 & $90^{\circ}$ & - \\
\hline MF4 & MODELO FíSICO & $\mathrm{HS}+\mathrm{COM}$ & solo 1 & 1700 & $90^{\circ}$ & - \\
\hline MF5 & MODELO FíSICO & $\mathrm{HS}+\mathrm{COM}$ & solo 2 & 11 & $90^{\circ}$ & - \\
\hline MF6 & MODELO FíSICO & $\mathrm{HS}+\mathrm{COM}$ & solo 2 & 100 & $90^{\circ}$ & - \\
\hline MF7 & MODELO FíSICO & $\mathrm{HS}+\mathrm{COM}$ & solo 2 & 750 & $90^{\circ}$ & - \\
\hline MF8 & MODELO FíSICO & $\mathrm{HS}+\mathrm{COM}$ & solo 2 & 1700 & $90^{\circ}$ & - \\
\hline MF9 & MODELO FíSICO & $\mathrm{HS}+\mathrm{COM}$ & solo 3 & 11 & $90^{\circ}$ & - \\
\hline MF10 & MODELO FíSICO & $\mathrm{HS}+\mathrm{COM}$ & solo 3 & 100 & $90^{\circ}$ & - \\
\hline MF11 & MODELO FíSICO & $\mathrm{HS}+\mathrm{COM}$ & solo 3 & 750 & $90^{\circ}$ & - \\
\hline MF12 & MODELO FíSICO & $\mathrm{HS}+\mathrm{COM}$ & solo 3 & 1700 & $90^{\circ}$ & - \\
\hline MF13 & MODELO FíSICO & $\mathrm{HS}+\mathrm{COM}$ & solo 4 & 11 & $90^{\circ}$ & - \\
\hline MF14 & MODELO FíSICO & $\mathrm{HS}+\mathrm{COM}$ & solo 4 & 100 & $90^{\circ}$ & - \\
\hline MF15 & MODELO FíSICO & $\mathrm{HS}+\mathrm{COM}$ & solo 4 & 750 & $90^{\circ}$ & - \\
\hline MF16 & MODELO FíSICO & $\mathrm{HS}+\mathrm{COM}$ & solo 4 & 1700 & $90^{\circ}$ & - \\
\hline MF17 & MODELO FíSICO & $\mathrm{HS}+\mathrm{COM}$ & solo 5 & 11 & $90^{\circ}$ & - \\
\hline MF18 & MODELO FíSICO & $\mathrm{HS}+\mathrm{COM}$ & solo 5 & 100 & $90^{\circ}$ & - \\
\hline MF19 & MODELO FíSICO & $\mathrm{HS}+\mathrm{COM}$ & solo 5 & 750 & $90^{\circ}$ & - \\
\hline MF20 & MODELO FíSICO & $\mathrm{HS}+\mathrm{COM}$ & solo 5 & 1700 & $90^{\circ}$ & - \\
\hline ALT 1 & $\begin{array}{c}\text { MSRG alteado } \\
\text { sucessivamente } \\
\text { até } 20 \text { metros } \\
\text { (ALT } 20 \mathrm{~m})\end{array}$ & MC & solo 2 & 11 & $3 \mathrm{~V}: 1 \mathrm{H}$ & ruptura $10,8 \mathrm{~m}$ \\
\hline ALT 2 & MSRG ALT $20 \mathrm{~m}$ & $\mathrm{MC}$ & solo 2 & 100 & $3 \mathrm{~V}: 1 \mathrm{H}$ & ruptura $10,8 \mathrm{~m}$ \\
\hline ALT 3 & MSRG ALT $20 \mathrm{~m}$ & $\mathrm{MC}$ & solo 2 & 500 & $3 \mathrm{~V}: 1 \mathrm{H}$ & - \\
\hline ALT 4 & MSRG ALT $20 \mathrm{~m}$ & $\mathrm{MC}$ & solo 4 & 11 & $3 \mathrm{~V}: 1 \mathrm{H}$ & ruptura $11,7 \mathrm{~m}$ \\
\hline ALT 5 & MSRG ALT $20 \mathrm{~m}$ & $\mathrm{MC}$ & solo 4 & 100 & $3 \mathrm{~V}: 1 \mathrm{H}$ & ruptura $16,2 \mathrm{~m}$ \\
\hline ALT 6 & MSRG ALT $20 \mathrm{~m}$ & $\mathrm{MC}$ & solo 4 & 500 & $3 \mathrm{~V}: 1 \mathrm{H}$ & - \\
\hline
\end{tabular}




\begin{tabular}{|c|c|c|c|c|c|c|}
\hline ALT 7 & MSRG ALT $20 \mathrm{~m}$ & $M C$ & solo 5 & 11 & $3 \mathrm{~V}: 1 \mathrm{H}$ & ruptura $8,1 \mathrm{~m}$ \\
\hline ALT 8 & MSRG ALT $20 \mathrm{~m}$ & $\mathrm{MC}$ & solo 5 & 100 & $3 \mathrm{~V}: 1 \mathrm{H}$ & ruptura19,8m \\
\hline ALT 9 & MSRG ALT $20 \mathrm{~m}$ & $\mathrm{MC}$ & solo 5 & 500 & $3 \mathrm{~V}: 1 \mathrm{H}$ & - \\
\hline ALT 10 & MSRG ALT $20 \mathrm{~m}$ & $\mathrm{MC}$ & granular & 10 & $3 \mathrm{~V}: 1 \mathrm{H}$ & ruptura $3 m$ \\
\hline ALT 11 & MSRG ALT $20 \mathrm{~m}$ & $\mathrm{MC}$ & granular & 100 & $3 \mathrm{~V}: 1 \mathrm{H}$ & ruptura $6 \mathrm{~m}$ \\
\hline ALT 12 & MSRG ALT $20 \mathrm{~m}$ & $\mathrm{MC}$ & granular & 500 & $3 \mathrm{~V}: 1 \mathrm{H}$ & - \\
\hline ALT 13 & MSRG ALT $20 \mathrm{~m}$ & MC & granular & 1000 & $3 \mathrm{~V}: 1 \mathrm{H}$ & - \\
\hline ALT 14 & MSRG ALT $20 \mathrm{~m}$ & $\mathrm{MC} \mathrm{e}=60 \mathrm{~cm}$ & granular & 10 & $3 \mathrm{~V}: 1 \mathrm{H}$ & ruptura 3m \\
\hline ALT 15 & MSRG ALT $20 \mathrm{~m}$ & $\mathrm{MC} \mathrm{e}=60 \mathrm{~cm}$ & granular & 100 & $3 \mathrm{~V}: 1 \mathrm{H}$ & ruptura $4,5 \mathrm{~m}$ \\
\hline ALT 16 & MSRG ALT $20 \mathrm{~m}$ & $\mathrm{MC} \mathrm{e}=60 \mathrm{~cm}$ & granular & 500 & $3 \mathrm{~V}: 1 \mathrm{H}$ & ruptura $16,5 \mathrm{~m}$ \\
\hline ALT 17 & MSRG ALT $20 \mathrm{~m}$ & $\mathrm{MC} \mathrm{e}=60 \mathrm{~cm}$ & granular & 1000 & $3 \mathrm{~V}: 1 \mathrm{H}$ & - \\
\hline ALT 18 & MSRG ALT $20 \mathrm{~m}$ & $M C$ & granular & 10 & $9 \mathrm{~V}: 1 \mathrm{H}$ & ruptura $3 \mathrm{~m}$ \\
\hline ALT 19 & MSRG ALT $20 \mathrm{~m}$ & $\mathrm{MC}$ & granular & 100 & $9 \mathrm{~V}: 1 \mathrm{H}$ & ruptura $6 \mathrm{~m}$ \\
\hline ALT 20 & MSRG ALT $20 \mathrm{~m}$ & $\mathrm{MC}$ & granular & 500 & $9 \mathrm{~V}: 1 \mathrm{H}$ & - \\
\hline ALT 21 & MSRG ALT $20 \mathrm{~m}$ & $\mathrm{MC}$ & granular & 1000 & $9 \mathrm{~V}: 1 \mathrm{H}$ & - \\
\hline ALT 22 & MSRG ALT $20 \mathrm{~m}$ & $M C ~ e=60 \mathrm{~cm}$ & granular & 10 & $9 \mathrm{~V}: 1 \mathrm{H}$ & erro \\
\hline ALT 23 & MSRG ALT $20 \mathrm{~m}$ & $\mathrm{MC} \mathrm{e}=60 \mathrm{~cm}$ & granular & 100 & $9 \mathrm{~V}: 1 \mathrm{H}$ & ruptura $4,5 \mathrm{~m}$ \\
\hline ALT 24 & MSRG ALT $20 \mathrm{~m}$ & $M C ~ e=60 \mathrm{~cm}$ & granular & 500 & $9 \mathrm{~V}: 1 \mathrm{H}$ & ruptura $15 \mathrm{~m}$ \\
\hline ALT 25 & MSRG ALT $20 \mathrm{~m}$ & $\mathrm{MC} \mathrm{e}=60 \mathrm{~cm}$ & granular & 1000 & $9 \mathrm{~V}: 1 \mathrm{H}$ & - \\
\hline ALT 26 & MSRG ALT $20 \mathrm{~m}$ & $\mathrm{MC}$ & coesivo & 10 & $3 \mathrm{~V}: 1 \mathrm{H}$ & ruptura $7,5 \mathrm{~m}$ \\
\hline ALT 27 & MSRG ALT $20 \mathrm{~m}$ & $\mathrm{MC}$ & coesivo & 100 & $3 \mathrm{~V}: 1 \mathrm{H}$ & ruptura $10,5 \mathrm{~m}$ \\
\hline ALT 28 & MSRG ALT $20 \mathrm{~m}$ & $\mathrm{MC}$ & coesivo & 500 & $3 \mathrm{~V}: 1 \mathrm{H}$ & - \\
\hline ALT 29 & MSRG ALT $20 \mathrm{~m}$ & $\mathrm{MC}$ & coesivo & 1000 & $3 \mathrm{~V}: 1 \mathrm{H}$ & - \\
\hline ALT 30 & MSRG ALT $20 \mathrm{~m}$ & $\mathrm{MC} \mathrm{e}=60 \mathrm{~cm}$ & coesivo & 10 & $3 \mathrm{~V}: 1 \mathrm{H}$ & ruptura $7,5 \mathrm{~m}$ \\
\hline ALT 31 & MSRG ALT $20 \mathrm{~m}$ & $\mathrm{MC} \mathrm{e}=60 \mathrm{~cm}$ & coesivo & 100 & $3 \mathrm{~V}: 1 \mathrm{H}$ & ruptura 9m \\
\hline ALT 32 & MSRG ALT $20 \mathrm{~m}$ & $\mathrm{MC} \mathrm{e}=60 \mathrm{~cm}$ & coesivo & 500 & $3 \mathrm{~V}: 1 \mathrm{H}$ & ruptura $18 \mathrm{~m}$ \\
\hline ALT 33 & MSRG ALT $20 \mathrm{~m}$ & $\mathrm{MC} \mathrm{e}=60 \mathrm{~cm}$ & coesivo & 1000 & $3 \mathrm{~V}: 1 \mathrm{H}$ & - \\
\hline ALT 34 & MSRG ALT $20 \mathrm{~m}$ & $\mathrm{MC}$ & coesivo & 10 & $9 \mathrm{~V}: 1 \mathrm{H}$ & ruptura $6 \mathrm{~m}$ \\
\hline ALT 35 & MSRG ALT $20 \mathrm{~m}$ & $\mathrm{MC}$ & coesivo & 100 & $9 \mathrm{~V}: 1 \mathrm{H}$ & ruptura $13,5 \mathrm{~m}$ \\
\hline ALT 36 & MSRG ALT $20 \mathrm{~m}$ & $\mathrm{MC}$ & coesivo & 500 & $9 \mathrm{~V}: 1 \mathrm{H}$ & - \\
\hline ALT 37 & MSRG ALT $20 \mathrm{~m}$ & $\mathrm{MC}$ & coesivo & 1000 & $9 \mathrm{~V}: 1 \mathrm{H}$ & - \\
\hline ALT 38 & MSRG ALT $20 \mathrm{~m}$ & $M C ~ e=60 \mathrm{~cm}$ & coesivo & 10 & $9 \mathrm{~V}: 1 \mathrm{H}$ & ruptura $6 \mathrm{~m}$ \\
\hline ALT 39 & MSRG ALT $20 \mathrm{~m}$ & $M C ~ e=60 \mathrm{~cm}$ & coesivo & 100 & $9 \mathrm{~V}: 1 \mathrm{H}$ & ruptura $10,5 \mathrm{~m}$ \\
\hline ALT 40 & MSRG ALT $20 \mathrm{~m}$ & $M C$ e $=60 \mathrm{~cm}$ & coesivo & 500 & $9 \mathrm{~V}: 1 \mathrm{H}$ & ruptura $18 \mathrm{~m}$ \\
\hline ALT 41 & MSRG ALT $20 \mathrm{~m}$ & $\mathrm{MC} \mathrm{e}=60 \mathrm{~cm}$ & coesivo & 1000 & $9 \mathrm{~V}: 1 \mathrm{H}$ & - \\
\hline PARA 1 & MSRG ALT 5m & $M C$ & paramétrico & 11 & $3 \mathrm{~V}: 1 \mathrm{H}$ & ruptura $1,2 \mathrm{~m}$ \\
\hline PARA 2 & MSRG ALT 5m & $\mathrm{MC}$ & paramétrico & 11 & $3 \mathrm{~V}: 1 \mathrm{H}$ & ruptura $1,2 \mathrm{~m}$ \\
\hline PARA 3 & MSRG ALT 5m & $\mathrm{MC}$ & paramétrico & 11 & $3 \mathrm{~V}: 1 \mathrm{H}$ & ruptura $1,5 \mathrm{~m}$ \\
\hline PARA 4 & MSRG ALT 5m & $\mathrm{MC}$ & paramétrico & 11 & $3 \mathrm{~V}: 1 \mathrm{H}$ & - \\
\hline PARA 5 & MSRG ALT 5m & $\mathrm{MC}$ & paramétrico & 11 & $3 \mathrm{~V}: 1 \mathrm{H}$ & - \\
\hline PARA 6 & MSRG ALT 5m & $\mathrm{MC}$ & paramétrico & 11 & $3 \mathrm{~V}: 1 \mathrm{H}$ & - \\
\hline PARA 7 & MSRG ALT 5m & $\mathrm{MC}$ & paramétrico & 100 & $3 \mathrm{~V}: 1 \mathrm{H}$ & - \\
\hline PARA 8 & MSRG ALT 5m & $\mathrm{MC}$ & paramétrico & 100 & $3 \mathrm{~V}: 1 \mathrm{H}$ & - \\
\hline PARA 9 & MSRG ALT 5m & $\mathrm{MC}$ & paramétrico & 100 & $3 \mathrm{~V}: 1 \mathrm{H}$ & - \\
\hline PARA 10 & MSRG ALT 5m & $\mathrm{MC}$ & paramétrico & 500 & $3 \mathrm{~V}: 1 \mathrm{H}$ & - \\
\hline PARA 11 & MSRG ALT 10m & $\mathrm{MC}$ & paramétrico & 11 & $3 \mathrm{~V}: 1 \mathrm{H}$ & ruptura $6,9 \mathrm{~m}$ \\
\hline PARA 12 & MSRG ALT $10 \mathrm{~m}$ & $\mathrm{MC}$ & paramétrico & 500 & $3 \mathrm{~V}: 1 \mathrm{H}$ & - \\
\hline PAR 1 & $\begin{array}{l}\text { MSRG altura fixa } \\
\text { de } 10 \text { metros } \\
\text { (FIXO } 10 \mathrm{~m})\end{array}$ & MC & paramétrico & 1000 & $9 \mathrm{~V}: 1 \mathrm{H}$ & ruptura \\
\hline PAR 2 & MSRG FIXO $10 \mathrm{~m}$ & $\mathrm{MC}$ & paramétrico & 1000 & $9 \mathrm{~V}: 1 \mathrm{H}$ & - \\
\hline PAR 3 & MSRG FIXO $10 \mathrm{~m}$ & $\mathrm{MC}$ & paramétrico & 1000 & 9V:1H & - \\
\hline
\end{tabular}




\begin{tabular}{|c|c|c|c|c|c|c|}
\hline PAR 4 & MSRG FIXO $10 \mathrm{~m}$ & $M C$ & paramétrico & 1000 & $9 \mathrm{~V}: 1 \mathrm{H}$ & ruptura \\
\hline PAR 5 & MSRG FIXO $10 \mathrm{~m}$ & $\mathrm{MC}$ & paramétrico & 1000 & $9 \mathrm{~V}: 1 \mathrm{H}$ & - \\
\hline PAR 6 & MSRG FIXO $10 \mathrm{~m}$ & $\mathrm{MC}$ & paramétrico & 1000 & $9 \mathrm{~V}: 1 \mathrm{H}$ & - \\
\hline PAR 7 & MSRG FIXO $10 \mathrm{~m}$ & $\mathrm{MC}$ & paramétrico & 1000 & $9 \mathrm{~V}: 1 \mathrm{H}$ & ruptura \\
\hline PAR 8 & MSRG FIXO 10 m & $\mathrm{MC}$ & paramétrico & 1000 & $9 \mathrm{~V}: 1 \mathrm{H}$ & - \\
\hline PAR 9 & MSRG FIXO 10 m & $\mathrm{MC}$ & paramétrico & 1000 & $9 \mathrm{~V}: 1 \mathrm{H}$ & - \\
\hline PAR 10 & MSRG FIXO $10 \mathrm{~m}$ & $\mathrm{MC}$ & paramétrico & 1000 & $9 \mathrm{~V}: 1 \mathrm{H}$ & ruptura \\
\hline PAR 11 & MSRG FIXO $10 \mathrm{~m}$ & $\mathrm{MC}$ & paramétrico & 1000 & $9 \mathrm{~V}: 1 \mathrm{H}$ & - \\
\hline PAR 12 & MSRG FIXO 10 m & $\mathrm{MC}$ & paramétrico & 1000 & $9 \mathrm{~V}: 1 \mathrm{H}$ & - \\
\hline PAR 13 & MSRG FIXO 10 m & $\mathrm{MC}$ & paramétrico & 1000 & $9 \mathrm{~V}: 1 \mathrm{H}$ & - \\
\hline PAR 14 & MSRG FIXO $10 \mathrm{~m}$ & $\mathrm{MC}$ & paramétrico & 1000 & $9 \mathrm{~V}: 1 \mathrm{H}$ & - \\
\hline PAR 15 & MSRG FIXO 10 m & $\mathrm{MC}$ & paramétrico & 1000 & $9 \mathrm{~V}: 1 \mathrm{H}$ & - \\
\hline PAR 16 & MSRG FIXO $10 \mathrm{~m}$ & $\mathrm{MC}$ & paramétrico & 1000 & $9 \mathrm{~V}: 1 \mathrm{H}$ & - \\
\hline PAR 17 & MSRG FIXO $10 \mathrm{~m}$ & $\mathrm{MC}$ & paramétrico & 1000 & $9 \mathrm{~V}: 1 \mathrm{H}$ & - \\
\hline PAR 18 & MSRG FIXO $10 \mathrm{~m}$ & $\mathrm{MC}$ & paramétrico & 1000 & $9 \mathrm{~V}: 1 \mathrm{H}$ & - \\
\hline PAR 19 & MSRG FIXO $10 \mathrm{~m}$ & $\mathrm{MC}$ & paramétrico & 1000 & $9 \mathrm{~V}: 1 \mathrm{H}$ & - \\
\hline PAR 20 & MSRG FIXO $10 \mathrm{~m}$ & $\mathrm{MC}$ & paramétrico & 1000 & $9 \mathrm{~V}: 1 \mathrm{H}$ & - \\
\hline PAR 21 & MSRG FIXO $10 \mathrm{~m}$ & $\mathrm{MC}$ & paramétrico & 1000 & $9 \mathrm{~V}: 1 \mathrm{H}$ & - \\
\hline PAR 22 & MSRG FIXO 10 m & $\mathrm{MC}$ & paramétrico & 1000 & $9 \mathrm{~V}: 1 \mathrm{H}$ & - \\
\hline PAR 23 & MSRG FIXO $10 \mathrm{~m}$ & $\mathrm{MC}$ & paramétrico & 1000 & $9 \mathrm{~V}: 1 \mathrm{H}$ & - \\
\hline PAR 24 & MSRG FIXO $10 \mathrm{~m}$ & $\mathrm{MC}$ & paramétrico & 1000 & $9 \mathrm{~V}: 1 \mathrm{H}$ & - \\
\hline PAR 25 & MSRG FIXO $10 \mathrm{~m}$ & $\mathrm{MC}$ & paramétrico & 1000 & $9 \mathrm{~V}: 1 \mathrm{H}$ & - \\
\hline PAR 26 & MSRG FIXO $10 \mathrm{~m}$ & $\mathrm{MC}$ & paramétrico & 1000 & $9 \mathrm{~V}: 1 \mathrm{H}$ & - \\
\hline PAR 27 & MSRG FIXO $10 \mathrm{~m}$ & $\mathrm{MC}$ & paramétrico & 1000 & $9 \mathrm{~V}: 1 \mathrm{H}$ & - \\
\hline PAR 28 & MSRG FIXO $10 \mathrm{~m}$ & $\mathrm{MC}$ & paramétrico & 1000 & $9 \mathrm{~V}: 1 \mathrm{H}$ & - \\
\hline PAR 29 & MSRG FIXO $10 \mathrm{~m}$ & $\mathrm{MC}$ & paramétrico & 1000 & $9 \mathrm{~V}: 1 \mathrm{H}$ & - \\
\hline PAR 30 & MSRG FIXO $10 \mathrm{~m}$ & $\mathrm{MC}$ & paramétrico & 1000 & $9 \mathrm{~V}: 1 \mathrm{H}$ & - \\
\hline PAR 31 & MSRG FIXO $10 \mathrm{~m}$ & $\mathrm{MC}$ & paramétrico & 1000 & $9 \mathrm{~V}: 1 \mathrm{H}$ & - \\
\hline PAR 32 & MSRG FIXO $10 \mathrm{~m}$ & $\mathrm{MC}$ & paramétrico & 1000 & $9 \mathrm{~V}: 1 \mathrm{H}$ & - \\
\hline PAR 33 & MSRG FIXO $10 \mathrm{~m}$ & $\mathrm{MC}$ & paramétrico & 1000 & $9 \mathrm{~V}: 1 \mathrm{H}$ & - \\
\hline PAR 34 & MSRG FIXO $10 \mathrm{~m}$ & $\mathrm{MC}$ & paramétrico & 1000 & $9 \mathrm{~V}: 1 \mathrm{H}$ & - \\
\hline PAR 35 & MSRG FIXO 10 m & $\mathrm{MC}$ & paramétrico & 1000 & $9 \mathrm{~V}: 1 \mathrm{H}$ & - \\
\hline PAR 36 & MSRG FIXO 10 m & $\mathrm{MC}$ & paramétrico & 1000 & $9 \mathrm{~V}: 1 \mathrm{H}$ & - \\
\hline PAR 37 & MSRG FIXO $10 \mathrm{~m}$ & $\mathrm{MC}$ & paramétrico & 1000 & $9 \mathrm{~V}: 1 \mathrm{H}$ & - \\
\hline PAR 38 & MSRG FIXO $10 \mathrm{~m}$ & $\mathrm{MC}$ & paramétrico & 1000 & $9 \mathrm{~V}: 1 \mathrm{H}$ & - \\
\hline PAR 39 & MSRG FIXO $10 \mathrm{~m}$ & $\mathrm{MC}$ & paramétrico & 1000 & $9 \mathrm{~V}: 1 \mathrm{H}$ & - \\
\hline PAR 40 & MSRG FIXO 10 m & $\mathrm{MC}$ & paramétrico & 1000 & $9 \mathrm{~V}: 1 \mathrm{H}$ & - \\
\hline PAR 41 & MSRG FIXO $10 \mathrm{~m}$ & $\mathrm{MC}$ & paramétrico & 1000 & $9 \mathrm{~V}: 1 \mathrm{H}$ & - \\
\hline PAR 42 & MSRG FIXO $10 \mathrm{~m}$ & $\mathrm{MC}$ & paramétrico & 1000 & $9 \mathrm{~V}: 1 \mathrm{H}$ & erro \\
\hline PAR 43 & MSRG FIXO 10 m & $\mathrm{MC}$ & paramétrico & 1000 & $9 \mathrm{~V}: 1 \mathrm{H}$ & - \\
\hline PAR 44 & MSRG FIXO $10 \mathrm{~m}$ & $\mathrm{MC}$ & paramétrico & 1000 & $9 \mathrm{~V}: 1 \mathrm{H}$ & - \\
\hline PAR 45 & MSRG FIXO $10 \mathrm{~m}$ & $\mathrm{MC}$ & paramétrico & 1000 & $9 \mathrm{~V}: 1 \mathrm{H}$ & - \\
\hline PAR 46 & MSRG FIXO $10 \mathrm{~m}$ & $\mathrm{MC}$ & paramétrico & 1000 & $9 \mathrm{~V}: 1 \mathrm{H}$ & - \\
\hline PAR 47 & MSRG FIXO $10 \mathrm{~m}$ & $\mathrm{MC}$ & paramétrico & 1000 & $9 \mathrm{~V}: 1 \mathrm{H}$ & - \\
\hline PAR 48 & MSRG FIXO $10 \mathrm{~m}$ & $\mathrm{MC}$ & paramétrico & 1000 & $9 \mathrm{~V}: 1 \mathrm{H}$ & - \\
\hline INCL 1 & MSRG FIXO $10 \mathrm{~m}$ & $\mathrm{MC}$ & paramétrico & 1000 & $3 \mathrm{~V}: 1 \mathrm{H}$ & - \\
\hline INCL 2 & MSRG FIXO $10 \mathrm{~m}$ & $\mathrm{MC}$ & paramétrico & 1000 & $6 \mathrm{~V}: 1 \mathrm{H}$ & - \\
\hline INCL 3 & MSRG FIXO $10 \mathrm{~m}$ & $\mathrm{MC}$ & paramétrico & 1000 & $9 \mathrm{~V}: 1 \mathrm{H}$ & - \\
\hline INCL 4 & MSRG FIXO $10 \mathrm{~m}$ & $\mathrm{MC}$ & paramétrico & 1000 & $3 \mathrm{~V}: 1 \mathrm{H}$ & - \\
\hline INCL 5 & MSRG FIXO 10 m & $\mathrm{MC}$ & paramétrico & 1000 & $6 \mathrm{~V}: 1 \mathrm{H}$ & - \\
\hline INCL 6 & MSRG FIXO $10 \mathrm{~m}$ & $\mathrm{MC}$ & paramétrico & 1000 & $9 \mathrm{~V}: 1 \mathrm{H}$ & - \\
\hline INCL 7 & MSRG FIXO $10 \mathrm{~m}$ & $\mathrm{MC}$ & paramétrico & 1000 & $3 \mathrm{~V}: 1 \mathrm{H}$ & - \\
\hline
\end{tabular}




\begin{tabular}{|c|c|c|c|c|c|c|}
\hline INCL 8 & MSRG FIXO $10 \mathrm{~m}$ & $M C$ & paramétrico & 1000 & $6 \mathrm{~V}: 1 \mathrm{H}$ & - \\
\hline INCL 9 & MSRG FIXO $10 \mathrm{~m}$ & $\mathrm{MC}$ & paramétrico & 1000 & $9 \mathrm{~V}: 1 \mathrm{H}$ & - \\
\hline INCL 10 & MSRG FIXO $10 \mathrm{~m}$ & $\mathrm{MC}$ & paramétrico & 1000 & $3 \mathrm{~V}: 1 \mathrm{H}$ & - \\
\hline INCL 11 & MSRG FIXO $10 \mathrm{~m}$ & $\mathrm{MC}$ & paramétrico & 1000 & $6 \mathrm{~V}: 1 \mathrm{H}$ & - \\
\hline INCL 12 & MSRG FIXO 10 m & $\mathrm{MC}$ & paramétrico & 1000 & $9 \mathrm{~V}: 1 \mathrm{H}$ & - \\
\hline INCL 13 & MSRG FIXO 10 m & $\mathrm{MC}$ & paramétrico & 1000 & $3 \mathrm{~V}: 1 \mathrm{H}$ & - \\
\hline INCL 14 & MSRG FIXO $10 \mathrm{~m}$ & $\mathrm{MC}$ & paramétrico & 1000 & $6 \mathrm{~V}: 1 \mathrm{H}$ & - \\
\hline INCL 15 & MSRG FIXO $10 \mathrm{~m}$ & $\mathrm{MC}$ & paramétrico & 1000 & $9 \mathrm{~V}: 1 \mathrm{H}$ & - \\
\hline INCL 16 & MSRG FIXO 10 m & $\mathrm{MC}$ & paramétrico & 1000 & $3 \mathrm{~V}: 1 \mathrm{H}$ & - \\
\hline INCL 17 & MSRG FIXO $10 \mathrm{~m}$ & $\mathrm{MC}$ & paramétrico & 1000 & $6 \mathrm{~V}: 1 \mathrm{H}$ & - \\
\hline INCL 18 & MSRG FIXO $10 \mathrm{~m}$ & $\mathrm{MC}$ & paramétrico & 1000 & $9 \mathrm{~V}: 1 \mathrm{H}$ & - \\
\hline INCL 19 & MSRG FIXO $10 \mathrm{~m}$ & $\mathrm{MC}$ & paramétrico & 1000 & $3 \mathrm{~V}: 1 \mathrm{H}$ & - \\
\hline INCL 20 & MSRG FIXO $10 \mathrm{~m}$ & $\mathrm{MC}$ & paramétrico & 1000 & $6 \mathrm{~V}: 1 \mathrm{H}$ & - \\
\hline INCL 21 & MSRG FIXO $10 \mathrm{~m}$ & $\mathrm{MC}$ & paramétrico & 1000 & $9 \mathrm{~V}: 1 \mathrm{H}$ & - \\
\hline INCL 22 & MSRG FIXO $10 \mathrm{~m}$ & $\mathrm{MC}$ & paramétrico & 1000 & $3 \mathrm{~V}: 1 \mathrm{H}$ & - \\
\hline INCL 23 & MSRG FIXO $10 \mathrm{~m}$ & $\mathrm{MC}$ & paramétrico & 1000 & $6 \mathrm{~V}: 1 \mathrm{H}$ & - \\
\hline INCL 24 & MSRG FIXO $10 \mathrm{~m}$ & $\mathrm{MC}$ & paramétrico & 1000 & $9 \mathrm{~V}: 1 \mathrm{H}$ & - \\
\hline ESP 1 & MSRG FIXO $10 \mathrm{~m}$ & $\mathrm{MC} \mathrm{e}=30 \mathrm{~cm}$ & granular & 10 & $9 \mathrm{~V}: 1 \mathrm{H}$ & ruptura \\
\hline ESP 2 & MSRG FIXO 10 m & $\mathrm{MC} \mathrm{e}=30 \mathrm{~cm}$ & granular & 100 & $9 \mathrm{~V}: 1 \mathrm{H}$ & ruptura \\
\hline ESP 3 & MSRG FIXO $10 \mathrm{~m}$ & $\mathrm{MC} \mathrm{e}=30 \mathrm{~cm}$ & granular & 500 & $9 \mathrm{~V}: 1 \mathrm{H}$ & - \\
\hline ESP 4 & MSRG FIXO $10 \mathrm{~m}$ & $\mathrm{MC} \mathrm{e}=30 \mathrm{~cm}$ & granular & 1000 & $9 \mathrm{~V}: 1 \mathrm{H}$ & - \\
\hline ESP 5 & MSRG FIXO $10 \mathrm{~m}$ & $\mathrm{MC} \mathrm{e}=60 \mathrm{~cm}$ & granular & 10 & $9 \mathrm{~V}: 1 \mathrm{H}$ & ruptura \\
\hline ESP 6 & MSRG FIXO $10 \mathrm{~m}$ & $\mathrm{MC} \mathrm{e}=60 \mathrm{~cm}$ & granular & 100 & $9 \mathrm{~V}: 1 \mathrm{H}$ & ruptura \\
\hline ESP 7 & MSRG FIXO $10 \mathrm{~m}$ & $\mathrm{MC} \mathrm{e}=60 \mathrm{~cm}$ & granular & 500 & $9 \mathrm{~V}: 1 \mathrm{H}$ & ruptura \\
\hline ESP 8 & MSRG FIXO $10 \mathrm{~m}$ & $\mathrm{MC} \mathrm{e}=60 \mathrm{~cm}$ & granular & 1000 & $9 \mathrm{~V}: 1 \mathrm{H}$ & - \\
\hline ESP 9 & MSRG FIXO $10 \mathrm{~m}$ & $\mathrm{MC} \mathrm{e}=90 \mathrm{~cm}$ & granular & 10 & $9 \mathrm{~V}: 1 \mathrm{H}$ & ruptura \\
\hline ESP 10 & MSRG FIXO $10 \mathrm{~m}$ & $\mathrm{MC} \mathrm{e}=90 \mathrm{~cm}$ & granular & 100 & $9 \mathrm{~V}: 1 \mathrm{H}$ & ruptura \\
\hline ESP 11 & MSRG FIXO $10 \mathrm{~m}$ & $\mathrm{MC} \mathrm{e}=90 \mathrm{~cm}$ & granular & 500 & $9 \mathrm{~V}: 1 \mathrm{H}$ & ruptura \\
\hline ESP 12 & MSRG FIXO $10 \mathrm{~m}$ & $\mathrm{MC} \mathrm{e}=90 \mathrm{~cm}$ & granular & 1000 & $9 \mathrm{~V}: 1 \mathrm{H}$ & ruptura \\
\hline ESP 13 & MSRG FIXO $10 \mathrm{~m}$ & $\mathrm{MC} \mathrm{e}=120 \mathrm{~cm}$ & granular & 10 & $9 \mathrm{~V}: 1 \mathrm{H}$ & ruptura \\
\hline ESP 14 & MSRG FIXO $10 \mathrm{~m}$ & $\mathrm{MC} \mathrm{e}=120 \mathrm{~cm}$ & granular & 100 & $9 \mathrm{~V}: 1 \mathrm{H}$ & ruptura \\
\hline ESP 15 & MSRG FIXO $10 \mathrm{~m}$ & $\mathrm{MC} \mathrm{e}=120 \mathrm{~cm}$ & granular & 500 & $9 \mathrm{~V}: 1 \mathrm{H}$ & ruptura \\
\hline ESP 16 & MSRG FIXO $10 \mathrm{~m}$ & $\mathrm{MC} \mathrm{e}=120 \mathrm{~cm}$ & granular & 1000 & $9 \mathrm{~V}: 1 \mathrm{H}$ & ruptura \\
\hline ESP 17 & MSRG FIXO $10 \mathrm{~m}$ & $\mathrm{MC} \mathrm{e}=30 \mathrm{~cm}$ & coesivo & 10 & $9 \mathrm{~V}: 1 \mathrm{H}$ & ruptura \\
\hline ESP 18 & MSRG FIXO $10 \mathrm{~m}$ & $\mathrm{MC} \mathrm{e}=30 \mathrm{~cm}$ & coesivo & 100 & $9 \mathrm{~V}: 1 \mathrm{H}$ & ruptura \\
\hline ESP 19 & MSRG FIXO $10 \mathrm{~m}$ & $\mathrm{MC} \mathrm{e}=30 \mathrm{~cm}$ & coesivo & 500 & $9 \mathrm{~V}: 1 \mathrm{H}$ & - \\
\hline ESP 20 & MSRG FIXO $10 \mathrm{~m}$ & $\mathrm{MC} \mathrm{e}=30 \mathrm{~cm}$ & coesivo & 1000 & $9 \mathrm{~V}: 1 \mathrm{H}$ & - \\
\hline ESP 21 & MSRG FIXO $10 \mathrm{~m}$ & $\mathrm{MC} \mathrm{e}=60 \mathrm{~cm}$ & coesivo & 10 & $9 \mathrm{~V}: 1 \mathrm{H}$ & ruptura \\
\hline ESP 22 & MSRG FIXO 10 m & $\mathrm{MC} \mathrm{e}=60 \mathrm{~cm}$ & coesivo & 100 & $9 \mathrm{~V}: 1 \mathrm{H}$ & ruptura \\
\hline ESP 23 & MSRG FIXO $10 \mathrm{~m}$ & $\mathrm{MC} \mathrm{e}=60 \mathrm{~cm}$ & coesivo & 500 & $9 \mathrm{~V}: 1 \mathrm{H}$ & - \\
\hline ESP 24 & MSRG FIXO $10 \mathrm{~m}$ & $\mathrm{MC} \mathrm{e}=60 \mathrm{~cm}$ & coesivo & 1000 & $9 \mathrm{~V}: 1 \mathrm{H}$ & - \\
\hline ESP 25 & MSRG FIXO $10 \mathrm{~m}$ & $\mathrm{MC} \mathrm{e}=90 \mathrm{~cm}$ & coesivo & 10 & $9 \mathrm{~V}: 1 \mathrm{H}$ & ruptura \\
\hline ESP 26 & MSRG FIXO $10 \mathrm{~m}$ & $\mathrm{MC} \mathrm{e}=90 \mathrm{~cm}$ & coesivo & 100 & $9 \mathrm{~V}: 1 \mathrm{H}$ & ruptura \\
\hline ESP 27 & MSRG FIXO $10 \mathrm{~m}$ & $\mathrm{MC} \mathrm{e}=90 \mathrm{~cm}$ & coesivo & 500 & $9 \mathrm{~V}: 1 \mathrm{H}$ & - \\
\hline ESP 28 & MSRG FIXO $10 \mathrm{~m}$ & $\mathrm{MC} \mathrm{e}=90 \mathrm{~cm}$ & coesivo & 1000 & $9 \mathrm{~V}: 1 \mathrm{H}$ & - \\
\hline ESP 29 & MSRG FIXO $10 \mathrm{~m}$ & $\mathrm{MC} \mathrm{e}=120 \mathrm{~cm}$ & coesivo & 10 & $9 \mathrm{~V}: 1 \mathrm{H}$ & ruptura \\
\hline ESP 30 & MSRG FIXO $10 \mathrm{~m}$ & $\mathrm{MC} \mathrm{e}=120 \mathrm{~cm}$ & coesivo & 100 & $9 \mathrm{~V}: 1 \mathrm{H}$ & ruptura \\
\hline ESP 31 & MSRG FIXO $10 \mathrm{~m}$ & $\mathrm{MC} \mathrm{e}=120 \mathrm{~cm}$ & coesivo & 500 & $9 \mathrm{~V}: 1 \mathrm{H}$ & erro \\
\hline ESP 32 & MSRG FIXO $10 \mathrm{~m}$ & $\mathrm{MC} \mathrm{e}=120 \mathrm{~cm}$ & coesivo & 1000 & $9 \mathrm{~V}: 1 \mathrm{H}$ & - \\
\hline ESP 33 & MSRG FIXO $10 \mathrm{~m}$ & $\mathrm{MC} \mathrm{e}=30 \mathrm{~cm}$ & alta coesão & 500 & $9 \mathrm{~V}: 1 \mathrm{H}$ & - \\
\hline ESP 34 & MSRG FIXO $10 \mathrm{~m}$ & $\mathrm{MC} \mathrm{e}=30 \mathrm{~cm}$ & alta coesão & 1000 & $9 \mathrm{~V}: 1 \mathrm{H}$ & - \\
\hline ESP 35 & MSRG FIXO $10 \mathrm{~m}$ & $\mathrm{MC} \mathrm{e}=60 \mathrm{~cm}$ & alta coesão & 500 & $9 \mathrm{~V}: 1 \mathrm{H}$ & - \\
\hline
\end{tabular}




\begin{tabular}{|l|l|l|l|c|c|c|}
\hline ESP 36 & MSRG FIXO $10 \mathrm{~m}$ & MC e $=60 \mathrm{~cm}$ & alta coesão & 1000 & $9 \mathrm{~V}: 1 \mathrm{H}$ & - \\
\hline ESP 37 & MSRG FIXO $10 \mathrm{~m}$ & MC e $=90 \mathrm{~cm}$ & alta coesão & 500 & $9 \mathrm{~V}: 1 \mathrm{H}$ & - \\
\hline ESP 38 & MSRG FIXO $10 \mathrm{~m}$ & MC e $=90 \mathrm{~cm}$ & alta coesão & 1000 & $9 \mathrm{~V}: 1 \mathrm{H}$ & - \\
\hline ESP 39 & MSRG FIXO $10 \mathrm{~m}$ & $M C$ e $=120 \mathrm{~cm}$ & alta coesão & 500 & $9 \mathrm{~V}: 1 \mathrm{H}$ & ruptura \\
\hline ESP 40 & MSRG FIXO $10 \mathrm{~m}$ & MC e=120cm & alta coesão & 1000 & $9 \mathrm{~V}: 1 \mathrm{H}$ & - \\
\hline
\end{tabular}

A partir dos dados obtidos das 188 combinações de variações nos modelos numéricos de solo reforçado, obtiveram-se subsídios para a construção gráfica com as medidas deslocamentos máxima na face e intensidade da solicitação do reforço em diversas situações. 